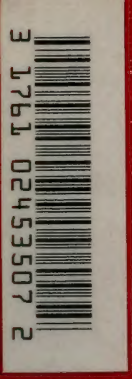




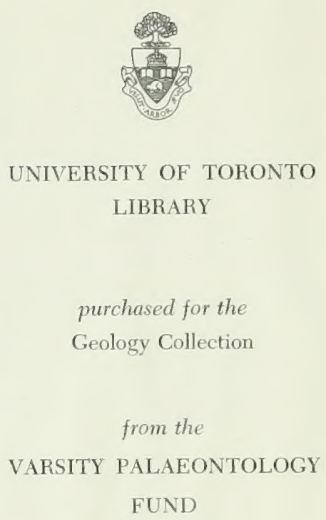


Digitized by the Internet Archive in 2010 with funding from University of Toronto 


UNIVERSITY OF CALIFORNIA PUBLICATIONS

BULLETIN OF THE DEPARTMENT OF

GEOLOGY

Vol. 8 , No. 22 , pp. $385-572$, pls. $42-71$

Issued August 30, 1915

FAUNA OF THE SAN PABLO GROUP OF: MIDDLE CALIFORNIA

BY

BRUCE L. CLARK

CONTENTS

Introduction and Acknowledgments

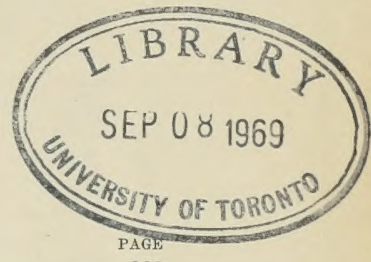

Historical Review

388

Historical Review

389

Geographic Oeeurrence of the San Pablo Group 393

The Stratigraphic Position and General Characters of the San Pablo Group

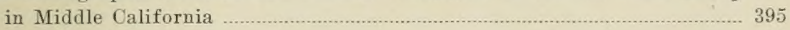

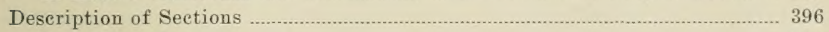

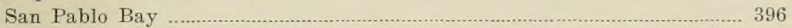

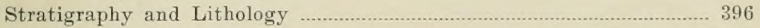

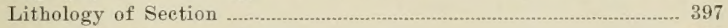

Relation to Monterey Group ………........ 398

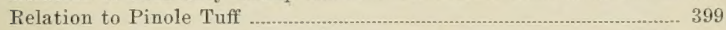

Detailed Section of the San Pablo Group as Measured on the North Side of the San Pablo Bay Syneline .......................................... 399

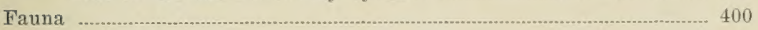

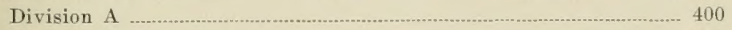

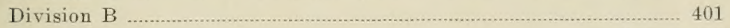

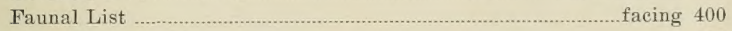

North Side of Mount Diablo _........................................................................ 402

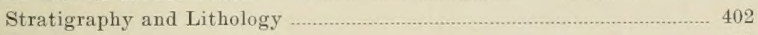

Fauna 402

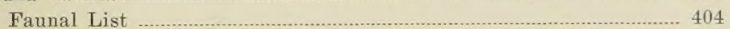

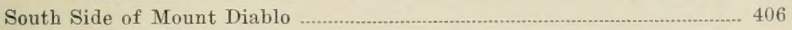

Stratigraphy and Lithology ................ 406

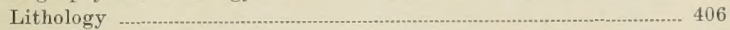

Relation to Monterey Group .................................................... 408

Relation to Pinole Tuff and Orindan .............................................. 408

Detailed Section of the San Pablo Group as Measured in the Vicinity

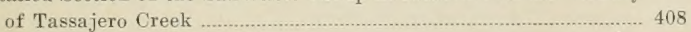




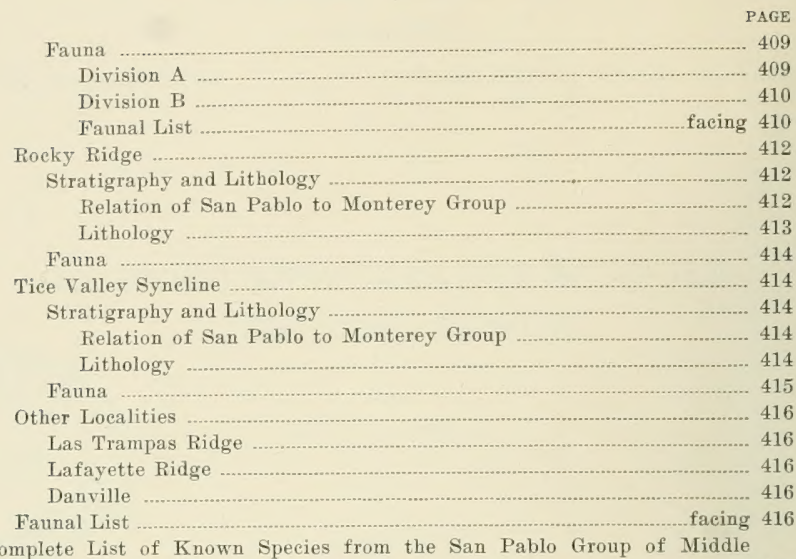

California, with Their Geologie Range .......................................... 416

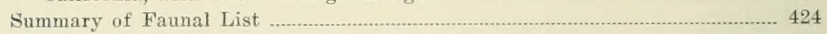

Summary of Evidence for Faunal Zones in San Pablo Group ...................... 424

Relation of San Pablo Fauna to Recent Fauna ………………....................... 427

Temperature Conditions of San Pablo Sea ………_.

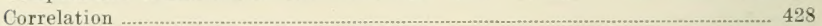

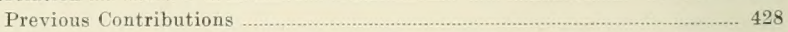

Position of San Pablo Group in the Neocene Section of California ........ 434

Relation to the Etchegoin and Other Formations which are Correlated

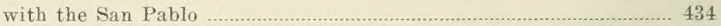

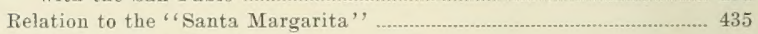

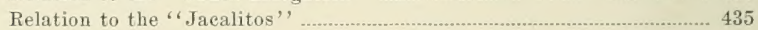

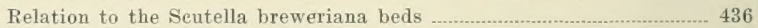

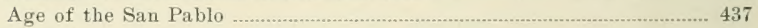

Conclusions ...

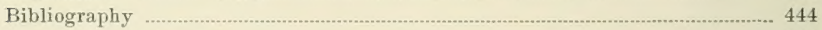

Deseription of Speeies _.................................... 446

Pelecypoda

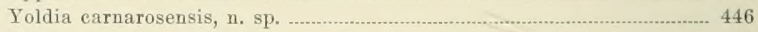

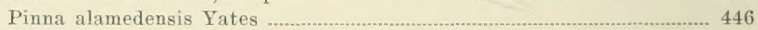

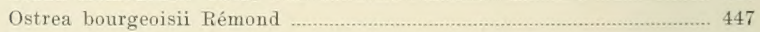

Pecten (Plagioctenium) bilineatus, n. sp. ............................................ 448

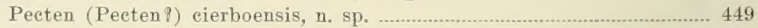

Pecten (Plagioetenium?) crassiradiatus, n. sp. ............................... 450

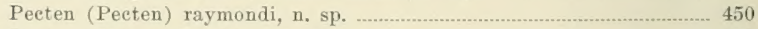

Peeten (Chlamys) pabloensis Conrad ………………............................. 452

Peeten (Pallium) holwayi, n. sp. ..................................................... 454

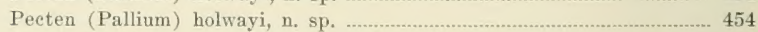

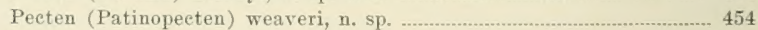

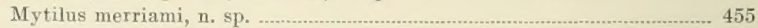

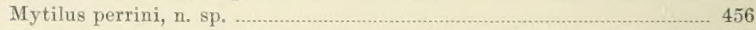

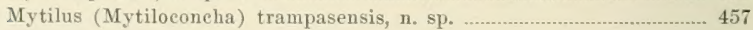




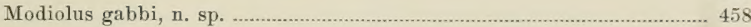

Cyrena (Corbieula) californiea Gabb …............................................... 459

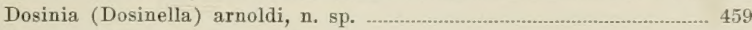

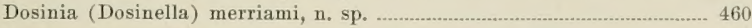

Dosinia (Dosinella) merriami var. oceidentalis, n. var. ....................... 462

Tivela (Pachydesma) diabloensis, n. sp. ........................................... 462

Tivela (Pachydesma) diabloensis var. angulatum, n. var. .................... 463

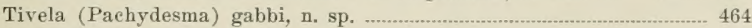

Amiantis (Amiantis) dalli, n. sp. ...................................................... 465

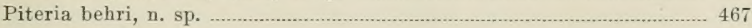

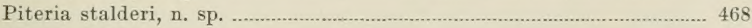

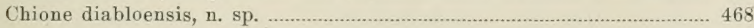

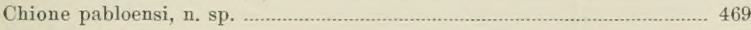

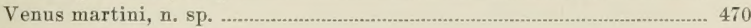

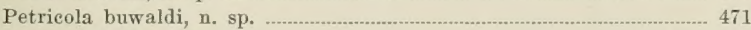

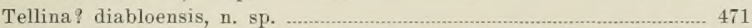

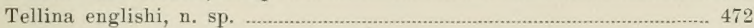

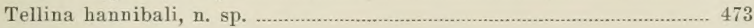

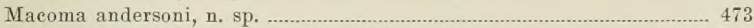

Macoma diabloensis, n. sp. ......... 475

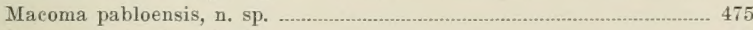

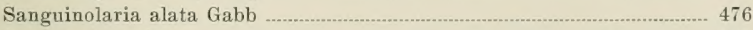

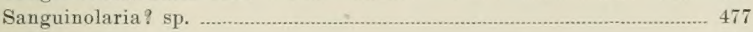

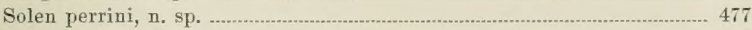

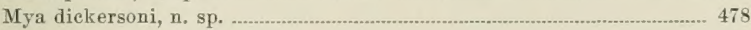

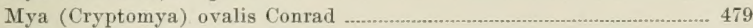

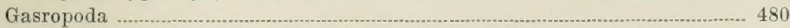

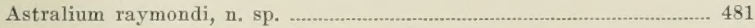

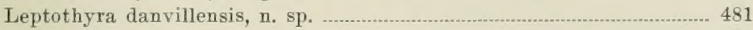

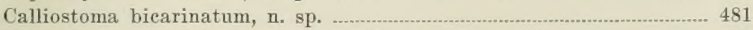

Calliostoma splendens Cpr. var. diabloensis, n. var. ............................. 482

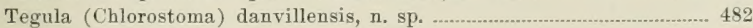

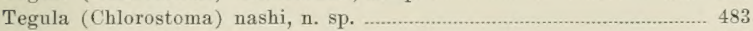

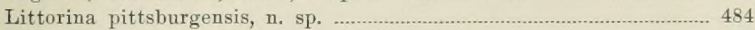

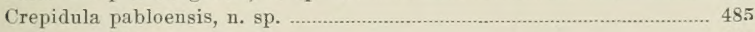

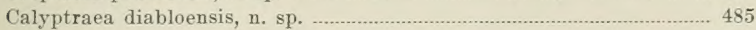

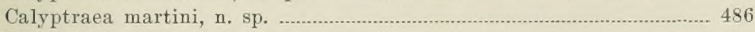

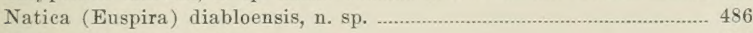

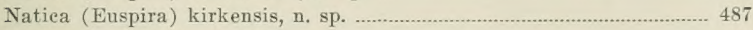

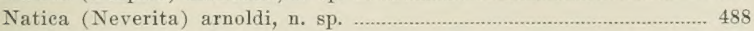

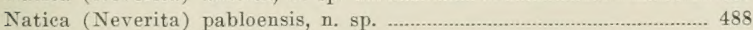

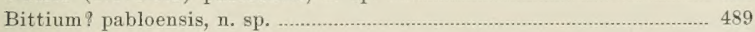

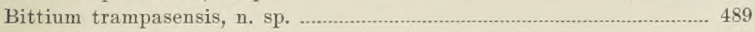

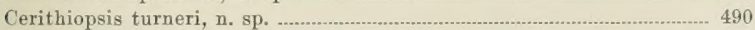

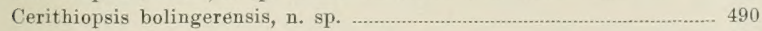

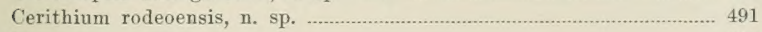

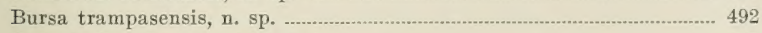

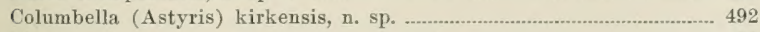

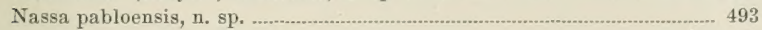

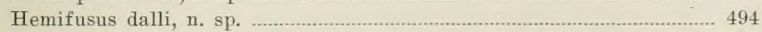

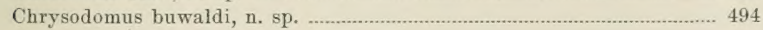




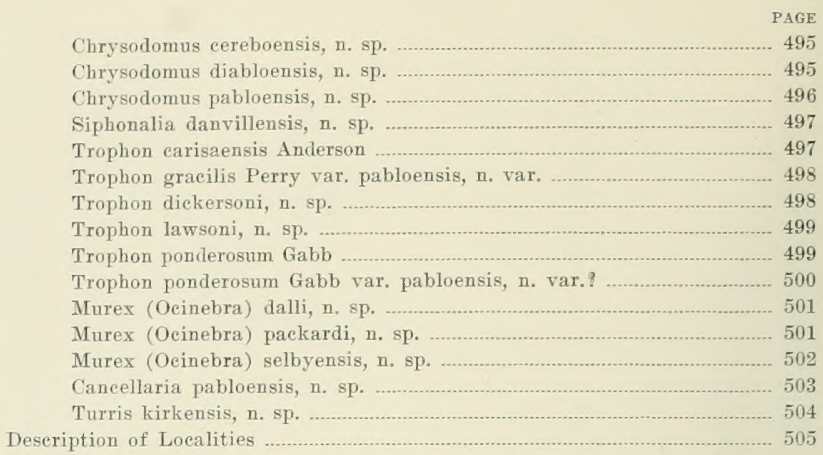

\section{INTRODUCTION AND ACKNOWLEDGMENTS}

The San Pablo Group, as described in this paper, represents what originally was defined by Dr. J. C. Merriam as the San Pablo formation or beds equivalent thereto. The preliminary work on the paper was begun in the summer of 1910 . The writer has been fortunate in having at his disposal the large collections from the San Pablo Group made by the classes in Palaeontology of the University of California Summer Sessions of 1910, 1911, and 1912. These collections were in part made under his direct supervision and in practically every case he has had first-hand knowledge of the field localities.

In presenting the paper it is realized that many problems have been left unsolved and that much remains to be known concerning the details of the fauna of the San Pablo Group of Middle California. It is hoped that the data given here will form a basis for a more complete study of the fauna of this horizon in the near future.

The writer wishes especially to express his acknowledgment to Dr. J. C. Merriam, under whose direction the work was begun. A few of the others to whom acknowledgments are due are Professor W. J. Raymond, Professor J. P. Smith, Dr. L. W. Stephenson, Dr. W. H. Dall, E. L. Packard, Harold Hannibal, Bruce Martin, and F. M. Anderson.

The writer is indebted to a number of persons for collections made in the San Pablo Group, but especially to Dr. John P. Buwalda. Dr. Buwalda, in making a geological section to the east of Walnut Creek, obtained some very fine material from the San Pablo Group in that vicinity. 


\section{HISTORICAL REVIETV}

The first general description of the geology in the vicinity of San Pablo Bay was made by Dr. J. S. Newberry in $1855 .{ }^{1}$ The deposits were correlated with the "sandstone of San Francisco" described on page eleven of the same volume. The Cretaceous, Eocene, Miocene, and Pliocene were included in the same series and designated as "Miocene or more recent." A fairly detailed description was given of a portion of this section, which is now recognized as belonging to the upper part of the San Pablo Group in the type section. Under the heading "Pecten Beds," Newberry makes the following statement:

My attention was first called to the fossiliferous beds by noticing a stratum which may perhaps be called a shell limestone about four feet in thiekness, which is composed almost exclusively of pectens. From its superior hardness it had resisted the action of the waves, which had cut deeply into the softer strata, and stood out like a wall, breast high, and running like a reef, far out into the shallow waters of the bay.

To one who is familiar with the east shore of San Pablo Bay, this locality can be easily recognized. It is less than one-fourth of a mile to the west of the town of Rodeo on the south side of Lone Tree Point. It was from these beds that the type of Pecten pabloensis Conrad was obtained. One other Pecten was found here which was described as being more than six inches in diameter. This was probably Pecten crassicardo Conrad, which oecurs at this horizon.

Doctor Newberry also recognized and described, fairly aceurately, the Pinole Tuff which, in this section, overlies the San Pablo.

The first writer to differentiate beds referred to the San Pablo Group, from the underlying Monterey (also Miocene) was Professor J. D. Whitney, ${ }^{2}$ who in 1865 recognized the division on the north side of Mount Diablo, but not in the vicinity of San Pablo Bay. The upper beds (San Pablo, Pinole Tuff and Oriudan) were referred to the Pliocene, the lower (Monterey Group), to the Miocene.

Whitney described the beds on the north side of Mount Diablo as follows :

Rocks of both Pliocene and Miocene age are extensively dereloped to the north of the strata just spoken of on the northern slope of the range in which are the coal mines. Those which we refer to the Miocene dirision of the Tertiary consist chiefly of sandstones which are very heavy bedded toward the

1 Pac. R. R. Report, vol. 6, Pp. 13-14, 1855.

a Geol. Survey Calif., vol. 1, p. 31, 1865 . 
hase of this series. They are succeded above by thinner and more fossiliferous strata which not only contain large numbers of marine fossils but also impressions of leaves and considerable fossil wood, the latter silicified and lying on the surface, the rock having decomposed above it. These upper strata are referred by $\mathrm{Mr}$. Gabb to the Pliocene division of the Tertiary, from a consideration of the number of recent species which they contain as well as from their stratigraphieal position.

On the south side of Mount Diablo, Whitney also described beds which are referable to the San Pablo Group. In one locality he found great quantities of leaf impressions and silicified wood and at another place a silicified tree stump was found "still upright-its roots in the leaf-bearing stratum and its top projecting into the next above." This locality is probably in the same horizon as the leaf shale of Corral Hollow and Railroad Ranch, deseribed by Turner in 1898.

In the second volume of the Palaeontology of California, published in connection with Whitney's volume on the geology of California, W. II. Gabb described a number of species from the Miocene of Middle California. Most of the State Survey work was of a reconnaissance nature and the fossil localities were so poorly described that few of them can be accurately located. Gabb did not attempt to separate the faunal zones. This work has, however, been of great value to later students, as is the other work of this great pioneer palaeontologist of California.

In 1863 August Rémond ${ }^{3}$ published deseriptions of the following species: Cardium gabbi (Pseudocardium gabbi) (Iulinia densata Conrad), Ostrea bourgeoisii, Astrodapsis whitneyi, Astrodapsis tumidus, Clypeaster gabbi (Scutella gabbi), and Echinarachnius brewerianus (Scutella breweriana). All of these, except the last, came from the San Pablo in the vicinity of Kirker Pass on the north side of Mount Diablo. Scutclla breweriana came from a point east of the town of Walnut Creek, and is one of the most characteristic forms of the horizon referred to in this paper as the Scutella breweriana zone.

In 1891 II. W. Turners published a paper on the Geology of MLount Diablo in which he described a section with "metamorphic" and igneous rocks at the base of the column, above which came the Cretaceous (Knoxville and Chico), Eocene (Tejon), Miocene, Pliocene and post-Pliocene. Turner stated that above the Knoxville there was apparently a conformable sequence of beds. Later work in this region has shown that uneonformities exist at various horizons in this section.

\footnotetext{
3 Proc. Calif, Acad. Sei., vol, 3, pp. 13 and 52-54, 1863-67.

4 Bull. Geol. Soc. Amer., vol. 2, pp. 383, 414, 1891.
} 
That part denoted as Pliocene by Turner includes what is now recognized as the San Pablo Group, the Pinole Tuff and the Orindan.

Turner gave a list of sixteen species of marine invertebrates, which was evidently taken from Gabb's paper; he also listed five others determined by Dall. These came from the north side of Mount Diablo in the vicinity of Kirker Pass.

In the paper just referred to, Turner also grave three lists of fossil leaves collected from strata now recognized as belonging to the San Pablo Group. One collection is from the north side of Mount Diablo and the other two are from the south side. Lesquereux, who determined the plant species, referred those from the north side of the mountain to the Pliocene and those from the south side to the Miocene.

The first writer to apply the name "San Pablo" and to differentiate it definitely from the formations above and below, was Professor J. C. Merriam, ${ }^{5}$ in a paper entitled "The Distribution of the Neocene SeaUrchins of Middle California." The purpose of this paper was to indicate the faunal zones of the Neocene, using the sea-urchins as the most characteristic species. In referring to the San Pablo, Merriam says :

The series of strata characterized by the presence of Astrodapsis and Scutella (Clypeaster) gabbi may, with reference to its most important features, be treated as a distinct formation and will be referred to in this paper as the San Pablo Formation.

The sea-urchins form the most prominent organic feature of the formation, neither of the Astrodapsis species being found outside of it. The zone of Scutella gabbi is not always present, but may be considered as belonging to the formation.

Merriam concluded that the San Pablo was an older formation than the Merced, the type section of which is situated just across the bay to the southwest of the type section of the San Pablo. He says:

If the Merced series be Pliocene, the San Pablo must be below the Upper Pliocene at least. It has already been shown to rest above what has been considered Miocene in Contra Costa County. In other words, it probably represents Middle Neocene. Such a determination of the age of this formation, it will be noticed, was, to some extent, foreshadowed by the reference of different localities of the same beds indifferently to the Miocene or Pliocene by the earlier writers on the geology of this region.

Two faunal zones were outlined in the San Pablo by Merriam; one was ealled the Scutella gabbi zone, the other the Astrodapsis zone.

5 Univ. Calif. Publ. Bull. Dept. Geol., vol. 2, no, 4, pp. 109-118, 1898. 
In the latter were found Astrodapsis tumidus and A. whitneyi. The Seutella gabbi zone was stated to be below and distinct from the Astrodapsis zone.

In $1898 \mathrm{H}$. W. Turner, ${ }^{6}$ in a paper on "The Rocks of the Mount Diablo Range of California," used the name "San Pablo Formation" for marine beds on the north and south sides of Mount Diablo which he had previously referred to the Pliocene and which he recognized to be the representative of the San Pablo of Merriam. In this paper Turner gives a detailed deseription of the San Pablo, especially in the region of Kirker Pass, accompanied by a diagrammatic section of the San Pablo in the vicinity of Kirker Creek on the north side of Mount Diablo. He divides the section into four zones-A, B, C and D.

Turner in this paper again mentions the leaf-bearing beds in the San Pablo and discusses the possibility of correlating these beds with the auriferous gravels of the Sierra Nevada on the basis of the leaf collections.

In 1899 Professor J. C. Merriam ${ }^{7}$ published a paper entitled "The Tertiary Sea Urchins of Middle California," in which he redescribed some of the most important of the Tertiary sea-urchins of California. The faunal zones of the San Pablo were outlined much as in his paper of the year hefore.

In 1909 Dr. C. E. Weavers published a paper on the "Stratigraphy and Palaeontology of the San Pablo Formation in Middle California," in which he described seven different sections of the San Pablo, including the type section on San Pablo Bay. Seventy-seven species of marine invertebrates are listed. He concluded that the San Pablo was of Pliocene age because of the large pereentage of Recent species.

In $1912,{ }^{9}$ the writer described in some detail the San Pablo section on the north side of Mount Diablo. Reference will be made later to this paper under the discussion of the San Pablo on the north side of Nount Diablo.

6 Jour. Geol., vol. 6, pp. 493-499, 1598.

- Proc. Calif. Acad. Sci., 3 d series, vol, 1, pp. 161-175, 1899.

8 Univ. Calif. Publ. Bull. Dept. Geol., vol. 5, pp. 243-269, 1909.

9 Clark, Bruce L., Unir. Calif. Publ. Bull. Dept. Geol., rol. 7, no. 4, pp. 47-60, [1. 7, 1912 . 


\section{GEOGRAPHIC OCCLRRENCE OF TIIE SAN PABLO GROT'P}

Beds equivalent to the San Pablo Group in California are fairly. widespread throughout the Coast Ranges, though they have not been generally recognized under this name. Marine beds of San Pablo age are, so far as known, absent on the east side of the Great Valley along the base of the Sierra Nevada. Deposits of this age are known more or less continuously throughout the Coast Ranges, from a little north of San Francisco Bay to as far south as Santa Barbara, Santa Barbara County, beyond which they have not been certainly recognized.

From north of San Franciseo Bay, C. E. Weaver ${ }^{10}$ listed five species of invertebrates from the San Pablo, and V. C. Osmont, ${ }^{11}$ in a paper entitled, "A Geological Section of the Coast Ranges North of the Bay of San Francisco," also recognized the San Pablo. The northern limit of the group is not known.

On the east side of the Coast Ranges along the Mount Diablo Range, the San Pablo Group is known at least as far south as Tesla or Corral Hollow. The geology of the region from Corral Hollow southward for a distance of over one hundred miles is not known in detail. In the region of Coalinga, beds equivalent to only a part of the San Pablo Group have been deseribed by Ralph Arnold, Robert Anderson, Harry Johnson, F. M. Anderson ${ }^{12}$ and others, under the name "Santa Margarita." The San Pablo group is known on the east side of the Coast Ranges as far south as the southern end of the San Joaquin Valley.

On the west side of the Coast Ranges, the San Pablo Group extends more or less interruptedly from the Santa Cruz Mountains, ${ }^{13}$ in Santa Cruz County, southward through Monterey County to at least as far south as the town of Santa Barbara.

10 Univ. Calif. Publ. Bull. Dept. Geol., vol. 5, no. 16, pp. 243-269, 1909.

11 Univ. Calif. Publ. Bull. Dept. Geol., vol. 4, no. 3, 1909.

12 Arnold, Ralph, and Anderson, Robert, Geology and oil resources of Coalinga, U. S. G. S. Bull. 398, 1910.

Arnold, Ralph, and Johnson, Harry, A preliminary report on the McKittriekSunset oil region, Kern and San Luis Obispo counties, Califormia, U. S. G. S. Bull. 406, 1910.

Anderson, Robert, Preliminary Report on the geology and oil prospects of the Cantua Panoche region, California, U. S. G. S. Bull. 431-A, pp. 54-83, 1911. Anderson, F, M., A stratigraphic study in the Mount Diablo Range of California, Proc. Calif. Acad. Sei., 3 d series, Geol., rol. 2, no. 2, 1905.

Anderson, F. M., A further study in the Mount Diablo Range of California, Proc. Calif. Acad. Sei., 4th series, rol. 3, pp. 1-40, 190 s.

13 Santa Cruz Folio, no. 163, p. 5, 1909. 
Ir. W. F. Jones, ${ }^{1 \text { in }}$ in a paper entitled "The Geology of the Sargent Oil Fields." (lescribed an area just to the southeast of the Santa Cruz quadrangle. In this paper he states that the Monterey shales (Lower Neocene) are unconformably overlain by the San Pablo: The fauna collected at the base of this so-called San Pablo contains species that are characteristic of the Etchegoin or Lower Purisima. Such species as Echinarachnius gibbsii, Pecten wattsi, Pecten oweni, Mytilus coalingensis, Glycimeris coalingensis, Thais kettlemanensis, ete., are rery abundant in these beds. As will be shown later, the fauna of the Etcheroin is believed to be very distinct from that of the San Pablo and much younger, being separated from it by a considerable time interval.

To the south of the Sargent oil fields very little is known about the formations of the upper Neocene until Salinas Valley is reached. The type section of the Santa Margarita formation (which is equivalent to the San Pablo Group to the north) as deseribed by Dr. II. W. Fairbanks, ${ }^{15}$ is near the sonth end of Salinas Valley in the vicinity of the tomn of Santa Margarita, San Luis Obispo County. Here the Santa Margarita rests unconformably on the Monterey shales (Lower Neocene). The desposits are known to extend fairly continuously along the north flank of the San Jose Range to the southeast of Salinas Valley, connecting with the beds mapped as Santa Margarita in the MeKittrick District and along the south and west sides of the San Joaquin Valley.

It is interesting to note that Dr. Fairbanks, ${ }^{16}$ in his first description of these beds, correlated them with the San Pablo of Middle California and gave to them that name. Later, in the San Luis Folio, the name was changed to Santa Margarita. On the maps of the folio Santa Nargarita is used as a local formation name and in the text the author refers the formation to the San Pablo Group.

14 Univ. Calif. Publ. Bull. Dept. Geol., vol. 6, no. 3, pp. 55-78, 1911.

15 San Luis Folio, No. 101, p. 10, 1904.

16 Fairbanks, H. WV, The stratigraphy of the California Coast Ranges, Jour. Geol., vol. 3, no. 4, 1903. 


\section{STRRATIIRAPIIC I'OSITION AND GENERAL CHARAC'TER OF THE SAN PABLO GROUP IN MIDDLE CALIFORNIA}

The best known sections of the San Pablo of Middle California lie to the east of San Francisco Bay. In this general region the formations or groups of formations that are found below the San Pablo. commencing at the bottom of the section, are the Franciscan (Jurassic), Knoxville (Cretaceous?), Chico (Upper Cretaceous), Martinez (Lower Eocene), Tejon (Upper Eocene), Monterey (Lower Neocene). Above the San Pablo there is usually a group of tuffs and fresh-water formations. The voleanics are generally known as the Pinole Tuff, the fresh-water sedimentaries as the Orindan formation. The Pinole Tuff is not everywhere present, in which case the Orindan formation may lie directly on the San Pablo. These fresh-water beds, as determined by Professor J. C. Merriam from the vertebrate remains, are approximately Upper Miocene or Lower Pliocene in age.

The distribution of the San Pablo Group in Middle California shows that insular or peninsular conditions existed in this region during San Pablo time. Beds of this group are absent in the hills just to the east of Berkeley and Oakland and on the San Francisco Peninsula; these areas were evidently land while the San Pablo deposits were being laid down. The eastern edge of this land mass was probably not more than two or three miles to the east of the cities of Berkeley and Oakland, and the San Pablo Sea extended eastward from here to the neighborhood of Mount Diablo. This last conclusion is arrived at from a study of the San Pablo deposits along the Mount Diablo anticline.

Professor A. C. Lawson, ${ }^{17}$ in referring in one of his papers to the distribution of the San Pablo in the vicinity of Berkeley, makes the following statement:

These beds of San Pablo are lacking in the Berkeley hills, though well developed on the shore of the Bay of San Francisco a few miles to the northward, and it is therefore believed that the San Pablo basin was one lying between insular or peninsular land masses, and that the region of the Berkeley hills was one of the land masses which remained unsubmerged in San Pablo times.

Whether this San Pablo Sea joined the ocean to the northward is not certainly known, but there are good reasons for believing that

\footnotetext{
17 Lawson, A. C., and Palache, C., The Berkeley Hills, a detail of Coast Range Geology, Univ, Calif. Publ. Bull. Dept. Geol., vol 2, no. 12, p. 447, 1902.
} 
the sea connected with the ocean to the south, as San Pablo outcrops are found fairly continuously from Mount Diablo southwestward to the eoast.

The character of the fauna obtained from the San Pablo beds to the east of San Francisco Bay shows that during a large part of San Pahlo time, true marine conditions existed. Intercalated with these typically marine beds at several horizons are beds which show evidence of having been deposited under estuarine or brackish-water conditions. In several of these sections. unconformities are found which the writer believes to be due probably to slight local oscillations of the earth's crust during San Pablo time. These movements affected the shore deposits but possibly not the beds deposited further off shore. To determine whether the estuarine or brackish-water deposits may be taken as evidence of general estuarine conditions in the San Pablo at these horizons, or whether they are merely shore phenomena, it will be necessary to study additional sections in detail, and more must be knom about the distribution of the San Pablo to the north.

\section{DESCRIPTION OF SECTIONS \\ SAN PABLO B.IY \\ STRATIGRAPHY AND LITHOLOGY}

The study of the type section on San Pablo Bay shows, if we are to accept the classification of the United States Geological Surrey, that the San Pablo should be classed as a group rather than as a formation. Here the thickness of the beds, as measured by the writer, is elose to trenty-two hundred and fifty feet. In this section the San Pablo is divisible into at least thirteen lithologie members. Good exposures are found, so that every member may be advantageously studied at some locality within the area. The basal beds are well exposed along the bay shore in the vicinity of the Union Oil Works to the west of Selby Station. Outerops of these beds may be followed for a distance of four or five miles to the southeast. The middle portion of the San Pablo is not well represented along the bay shore. but about two to three miles inland, on the south side of the symelime, beds of this part of the section may be found. The best exposures of the upper part of the wroup are on the north side of the syncline. about one mile to the southeast of the Union Oil Works. Also very good exposures of the upper beds are found to the east of and a little to the southwest of the town of Rodeo. At this last locality are the 
Pecten beds described by Newberry in the earliest description of the geology of the region.

The section on the bay shows great variation in lithology; and this is quite generally true of the San Pablo throughout Middle California. The beds are for the most part of a marine origin, as is proven by the great abundance of sea-urchins at various horizons. Interealated with these marine beds are deposits which are to be classed as of estuarine or brackish-water origin. Coarse conglomeratic sandstone predominates, with minor lavers of shale and finer sandstone. The sandstones in the upper part of the group are quite tuffaceous, as is also the case in the region of Mount Diablo.

Lithology of Section.-At the base of the group are seven hundred and fifty feet of coarse sandstone. These beds are made up of rather hard, fossiliferous, coarse, gray sandstone, alternating with massive, medium-coarse sandstones which are not fossiliferous. The harder beds are usually well exposed. Some of the hard layers are from ten to twenty feet in thickness while others are not more than a foot thick. The harder layers are usually very fossiliferous, though the preservation of the fossils is generally poor. Toward the base of this lower division the harder, fossiliferous strata are quite numerous and close together, but higher up the massive sandstones predominate.

The sandstones just described are overlain by about one hundred and forty feet of medium fine, yellowish brown, coneretionary sandstone, which is best exposed about two and one-half miles east of the town of Rodeo (Univ. Calif. Loc. 1532). Here the brown sandstones are overlain by a coarse, cross-bedded, tuffaceous, conglomeratic sandstone. Between the brown and the tuffaceous sandstones just described there is a sharp line of contact which, at several places, is irregular, the greatest difference of level noted being over three feet. Irregularities, such as might have been made by some kind of boring animal, were found along this contact, though no good evidence of true pholas borings was obtained. Whether this unconformity corresponds to the one in the San Pablo Group on the north side of the mountain, deseribed by the writer: ${ }^{18}$ or whether it comes at the same stratigraphic position as a limestone on Rocky Ridge near the southeast corner of the Concord quadrangle has not been determined. As will be seen from the description of the different sections, the character of the deposits of the San Pablo group in this part of the state is such that minor local unconformities are to be expected at various horizons.

18 Clark, Bruce L., Univ. Calif. Publ. Bull. Dept. Geol., vol. 7, no. 4, p. $5 \overline{5}$. 
The portion of the San Pablo, above the contact just described, has a thickness of about thirteen hundred and fifty feet. As the reader will see from the section on page 399 , it consists of a series of coarse sandstones, fine sandstones and shales. At the base are one hundred and fifteen feet of coarse gray, tuffaceous sandstone, already mentioned as lying above the fine concretionary sandstone. Above this are two hundred and twenty-five feet of medium fine, gray sandstone, followed by two hundred and fifty feet of coarse, cross-bedded, tuffaceous sandstones. The upper part of this last layer of coarse sandstone is marked by abundance of the species Mulinia densata. At one locality on the south side of the syncline, near the top of this member of the group, a layer of pure white tuff about a foot in thickness was found.

The coarse, tuffaceous sandstone is followed above by about ninety feet of pearl-gray shale which forms one of the most persistent members of the group on San Pablo Bay. The contacts between this shale and the underlying and overlying sandstones are quite sharp. Both above and below this member the change from coarse sandstone to shale takes place within a few inches. At one locality, about two miles to the east of Rodeo, a conglomerate, in which fairly large pebbles oceur, lies just above the shale. Some of the pebbles are two to three inches in diameter; most of them are made up of very fine sandstone from which one or two undeterminable fossils were obtained. Many of the pebbles contain bore-holes of the pholadid type.

Above the shale member, the outerops consist of alternating harder and softer sandstones with minor amounts of shale. The harder sandstones contain abundant specimens of the echinoderm, Astradapsis tumidus. In this part of the section, coarse sandstones predominate. The beds are very tuffaceous and in places show a distinctly blue color.

Relation to Honterey Group.- - In the region of San Pablo Bay there appears to be no appreciable difference in dip and strike between the Monterey Group and the San Pablo. At the point where the separation is made there is a fairly well marked change in lithology, the upper Monterey being a medium-fine, yellow-gray sandstone, while the lower San Pablo is a coarse conglomeratic sandstone. Dr. C. E. Weaver $^{10}$ described an unconformity in this region between the Mouterey and the San Pablo. He states that "areal mapping shows the different divisions of the Monterey to extend diagonally beneath the

10 Weaver, C. E., Stratigraphy and palaeontology of the San Pablo Formation in Middle California, Univ. Calif. Publ. Bull. Dept. Geol., vol. 5, no. 16, p. 251, 1909 . 
strike of the San Pablo Beds." Later work shows that the Monterey" shale, mapped as striking in under the San Pablo, in reality turns and may be traced back around the nose of the steeply-plunging anticline that is found to the southeast of the San Pablo Bay syncline. See map, plate 71 .

Relation to Pinole Tuff.-The San Pablo of the type section is overlain by several hundred feet of basaltic tuft's. The lower beds of tuff are quite coarse, containing considerable voleanic ejectamenta, and appear to have been laid down very rapidly. The upper strata are finer and are distinctly bedded. Clay beds are interbedded with the tuff. The Pinole Tuff appears to have been laid down, in part at least, under water as the casts of fresh-water shells are quite abundant.

The stratigraphic relationship of the Pinole Tuff to the San Pablo Group in this immediate vicinity is unconformable, as shown by an irregular contact and a slight difference in strike.

Detalled Section of the San Pablo Group, as Measured on the North Side of the San Pablo Bay Syncline

Pinole Tuff.

(Unconformity.)

San Pablo

Division B

FEET

Coarse gray sandstone

Thin layer of pinis shale

Coarse gray sandstone

Coarse gray, eross-bedded, tuffaceous sándstone, bedded with thin layers of clay; contains Mulinia densata and Tivela gabbi

Medium fine sandstone; toward bottom grades into shale

Heavy, massive, coarse sandstone with lentils of harder and darker sandstone; very fossiliferous

Gray, medium fine sandstone

Coarse, massive, gray sandstone with lentils of harder and darker sandstone; contains Astrodapsis tumidus, Pinna alamedensis, Trophon carisaensis, ete.

Pearl-gray shale

Medium fine, gray sandstone; contains Trophon lawsoni, Astrodapsis tumidus and Mulinia pabloensis

Medium fine, gray sandstone

Coarse gray, eonglomeratic, tuffaceous sandstone

Division A.

Medium fine, yellowish gray concretionary sandstone; contains Pitaria behri, Pitaria stalderi

Layers of coarse fossiliferous sandstone alternating with medium fine to coarse, massive, unfossiliferous layers of sandstone; Scutella gabbii found in the lower 250 feet, Astrodapsis tumidus, subsp. cierboensis, and Scutella pabloensis, in the upper 500 feet 


\section{FAUNA}

The San Pablo Bay section is here separated for the purposes of this paper into two parts, A and B. These divisions are in reality faunal divisions. As will be shown later, two major faunal zones are recognizable in the San Pablo of Middle California. The divisions $A$ and $B$, as used here, are the stratigraphic equivalents of these zones. Division A of the type section includes the lower members of the group, from the base to the irregular contact described above and possibly somewhat higher. This part of the section is about nine hundred feet thick. Division B includes the upper members of the group above the irregular contact, the thickness of which is about thirteen hundred feet.

Division A.-Three minor faunal zones are recognizable in division A. The lower two of these zones are based upon the sea-urehins therein contained. At the bottom of the series, the species Scutclla gabbii is found abundantly; two humdred feet stratigaphically above, Scutclla gabbii is but rarely found and Astrodapsis tumidus subsp. cierboensis makes its appearance. At the time Dr. Merriam ${ }^{20}$ wrote his paper outlining the famal zones of the San Pablo on the basis of the seaurchins, it was believed that the Scutella gabbii and Astrodapsis tumidus zones did not overlap. Later work has shown that the species Scutella gabbii extends into the upper Astrodapsis beds

At this point in the discussion, it may be well to call attention to the fact that with Astrodapsis tumidus subsp. cierbocusis in the second minor faunal zone of division $\mathrm{A}$, is found Scutella pabloensis Kew. both of which are found on the south side of the Mount Diablo anticline at a horizon believed to be the same as that in which they are found on San Pablo Bay.

The third minor faunal zone is one that has not been recognized outside of the bay section. The fauna of this zone comes from the fine sandstones at the top of division $\mathrm{A}$ where several species that do not appear in the coarser sandstones below have been found. These are Dosinia merriami, Pitaria behri, Pitaria stalderi, Calliostoma sp. indt. and Ficus cf. stanfordensis. Of these, the last four species have not been found outside of this section.

'The species which appear to be characteristic of division $A$ and of the lower San Pablo throughout middle California are Astrodapsis lumidus subsp. cierbocnsis, Scutella pablocnsis, Pecten wearcri, ('alifornia, Univ. Calif. I'ubl. Bull. Dept. Geol., vol. 2, no. 4, pn. 109-11s, 1598. 
FAUNAL LIST

ECHINODERMATA

$4074094101532 \quad 15331600160416051606160716081609161016111612161316141615161716181619162016211622162416251626162716281629168016311632 \quad 16331634$

Astrodapsis tumidus Rémond

Astrodapsis, species $a$, Upper San Pablo

Astrodapsis tumidus, subsp. cierboensis Kew

Asterias remondi Gabb

Sentella pabloensis Kerr

Seutella gabbii Rémond

CBUSTACEA

Balanus, species a

Balanns, species $b$

Brrozos-two species

PELECYPODA

Acila conradi Meek

Area trilineata Conrad

Cardium quadrigenarium Conrad

Unione, sp.9

Cyrena (Corbicula) ealifornica Gabb

Diplodonta orbella Gould

Diplodonta parilis Conra

Dosinia arnoldi, n. sp.

Dosinia merriami, n. sp. ............

Glycimeris septentrionalis Mida

Leda, sp. 9

Macoma secta Conrad

Macoma andersoni, n, sp.

Macoma nasuta Conrad

Macoma pabloensis, n, sp.
Modiolus directus

Modiolus directus Dall

Modiolus gabbi, n, sp. ...

Mujunia densata Conrad ......
Mulinea pabloensis Packat

Mya dickersoni, n. sp.

Mya (Cryptomya) ovalis Conrad

Mytius coalingensis Arnold, n, var.

Mirtilus perrini, $n$, sp. ................

Ustrea bourgeoisii Rém

Ostrea titan Courad ...

Papho generosa Gould .

Paphia staminea Conrad
Pecten bilineatus, n, sp. .

Pecten cierboensis, n. sp.

Pecten crassicardo Conrad
Pecten holwayi, n. sp.

Pecten pabloensis Conrad

Peeten raymondi, n, sp.

Pecten weaveri, n. sp.

Pitaria behri, no sp.

Sanguinolaria nuttallii Conrad

Sanguinolaria $1 \mathrm{n}$, ep.

Saxidomus nuttallii Conrad

Schizothaerus nuttallii Conrad

Schizothaerus pajaroanus Conrad

Siliqua lucida Conrad

solen perrini, n. sp.

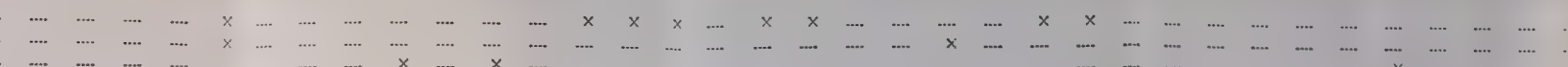

spisula abscissa Ga 
Ostrea titsu Conrad ...
Panope generosa Gould
Paphis stamines Conrad

Pecten bilinestus, n. sp.

Pecten cierboensis, n. sp.

Pecten holwayi, n. sp. ....
Pecten pabloensis Conrad

Pecten raymondi, n. sp.

Pecten weaveri, n. sp. -
Pinns alamedensis Yates

Pitaria behri, ns. sp.

Pitaria stalderi, no sp. ...........

Sanguinolaria n. sp. ...

Sasidomus nuttallii Conrad.

Sehizothaerus nuttallii Conrad ....

Sisiqua lucida Conrad

$\therefore$ ind perrini, $\mathrm{n}, \mathrm{sp}$.

rr.tull abscissa Gabb

Spusula catilliformis Conr
Spisula, ef, faleata Gould ..

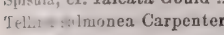

T.w. . . Hhensis, n. sp.

Tivela gabbi, n. sp. ..........................

Zirpbeas dontata Gabb

G $\triangle$ STROPOD

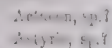

Bhitium nabloen

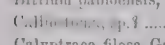

Calyptraen filosa Gabb

Chrysodomus imperialis Da

Chrysodomus pabloensis, D. 8 .

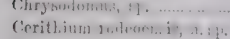

Dentalium, вp.

Epitonium borealis

Ficus, cf. st: lifordensis $A$ rnola

Hemifusus dalli, 3. Bp.

Murex (Ocinobra) dalis, n. sp.

Murex (Ocinebra) packardi, n. вp.

Murex (Ocinebra) selbyensis, n. sp.

Natica (Euspira) kirkensis, n. sp.

Natica (Neverita) arnoldi, n. sp.

Natica (Neverita) recluziana Petit

Natiea (Neverita) pabloensis, n. sp.

Thais lima Nartyn

Trophon carisaensis Anderson

Trophon carisaensis Ander

Trophon gracilis var. pabloensis, n. var. 
Spisula abscissa, Tivela diabloensis, Chrysodomus pabloensis, Murex sclbyensis.

Division $B$.-The most fossiliferous portion of division B is in the sandstones just above the band of shale already deseribed. Over forty species were obtained from this zone, a large number of which have never been found in division $\mathrm{A}$ or in the lower portion of any other section of the San Pablo Group. The species that appear to be characteristic of the zone and which are found in more than one section are Astrodapsis tumidus, Acila conradi, Cyrena californica, Macoma pabloensis, Macoma andersoni, Mytilus perrini, Mya dichersoni, Pinna alamedensis, Pecten pabloensis, Pecten bilineatus, Tivela gabbi, Natica (Meverita) arnoldi and Trophon carisaensis.

Astrodapsis tumidus is found in the beds above the shale in great abundance, and in some places the coarser sandstones are made up almost entirely of the individuals of this species. The Pecten beds reseribed by Dr. Newberry in the Pacific Railroad Reports are found in this horizon and the types of Pecton pabloensis Conrad, Pecten bilineatus, n. sp., Pecton holwayi, n. sp., were obtained from them. Pecten crassicardo is also found at this locality (Univ. Calif. Loe. 1632). Other localities are nos. 1613, 1614, and 1615.

The fauna found below the shale member in the upper San Pablo is not essentially different from that above with the exception of a few species, including Diplodonta parilis, Sanguinolaria muttalli, Tcllina salmonea and Trophon lawsoni.

A noteworthy fact in connection with the discussion of the fauna of division $\mathrm{B}$ is that in at least two zones we have estuarine or brackishwater deposits, as is evidenced by the presence in great abundance of the forms of Cyrena (Corbicula) and Iya, associated with genera which at the present time are found living under either estuarine or marine conditions. The first horizon of estuarine or brackish-water deposits is the shale member. In this the species Cyrena (Corbieula) californica was found, together with leaf impressions. The other zone is near the top of the group in medium fine sandstones. At locality 1617 in this zone certain layers are composed almost entirely of the shells of Cyrena (Corbicula) californica and Mya dickersoni. 


\section{T'me North Side of Mount Drablo STRATIGRAPIY AND LITHOLOGY}

The San Pablo Group on the north side of Mount Diablo has a maximum thickness of abont six hundred feet and a minimum thickness of about four hundred feet.

The deposits, especially in the lower part of the section, may be classed as distinctly those of a strand line, being largely composed of coarse conglomerates and cross-bedded sandstones. East of Kirker Creek, there is a well-marked irregular contact within and about three hundred feet above the base of the group, and at several localities the trunks of silicified trees were found standing at right angles to the contact. No difference in dip and strike was obtained between the beds above and below the unconformity.

The San Pablo above the unconformity in this section is formed largely of layers of bright blue sandstone and pearl-gray, tuffaceous shale. Near the top several small lenses of conglomerate were observed. There is considerable tuffaceous material throughout the group, and in the upper part of the section thin lavers of white tuft are quite common.

In this area the group unconformably overlies the Monterey Group and is in turn overlain uneonformably by the Pinole Tuft. The unconformity between the Monterey and San Pablo in this locality is of such a character as would seem to represent a fairly notable hiatus. Briefly, the evidence is as follows: 1 . At certain localities there is a difference in strike and dip between the two groups. 2. An irregular contact between the two was found at several places. 3. The basal beds of the group rest on different members of the Monterey as one follows the line of strike. 4. Borers of the pholadid type were found in the Monterey rock along the contact for a distance of over three miles. 5. Well-rounded pebbles lithologically identical with the tuffaceous sandstone and shale of the Monterey below, are found in the basal conglomerate.

\section{FAUNA}

The fama obtained from this section of the San Pablo Group was described by the writer ${ }^{22}$ in a former paper. A few changes have been made in the faunal list and a few species have been added to it.

"2 Clark, Bruce L., op. cit. 
Scutella gabbii is found at the base of the section. The most common species found with Scutella gabbii or in the same horizon are Dosinia merriami, Modiolus gabbi, Ostrea bourgeoisii, Pecten crassicardo, Siliqua lucida, Spisula abscissa, Spisula albaria, Spisula catilliformis, Cerithiopsis turneri and Natica (Euspira) kirkensis.

The beds of the upper portion of the lower San Pablo contain a number of species that do not appear in the basal beds, the most common of which are Mytilus coalingensis, n. var.?, Sanguinolaria alata, Calyptraea diablocnsis and Littorina remondii. Calyptraea diabloensis, Hytilus coalingensis $n$. var ? and Sanguinolaria alata appear to be characteristic of this horizon; all occur also on the south side of the Mount Diablo anticline associated with Astrodapsis tumidus subsp. cierboensis and Scutella pabloensis, together with an assemblage of species that is very similar to that on the north side of the mountain. Thus the two lower minor faunal zones of division $A$ of the Bay Section are also recognized on the north side of Mount Diablo.

The fauna of the upper San Pablo in this area is to be correlated with that of division B of the San Pablo Bay section. The characteristic species are Astrodapsis whitneyi, Cyrena (Corbicula) californica, and Trophon carisaensis. Ilere, as in the San Pablo Bay section, the great abundance of Cyrena (Corbicula) californica in the upper part of the group indicates brackish-water or estuarine conditions. 


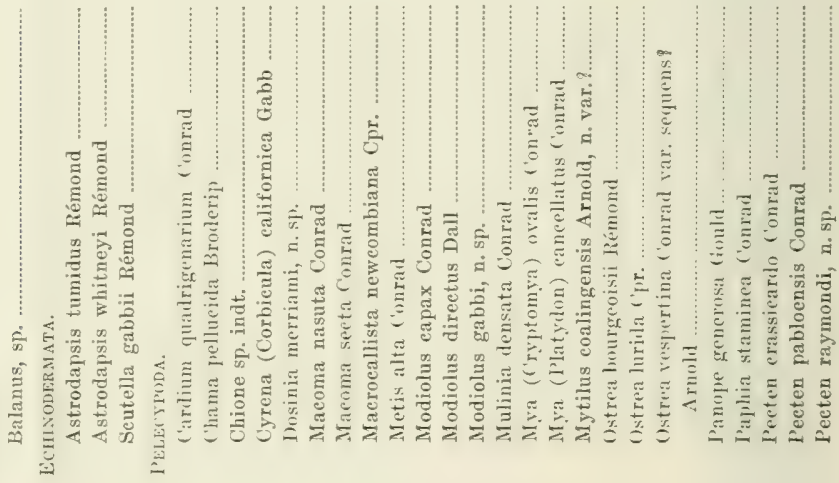


:

总

옹

हั

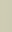

产

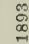

总

ఖ

罡

‡

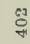

g

¿

잉

:

in

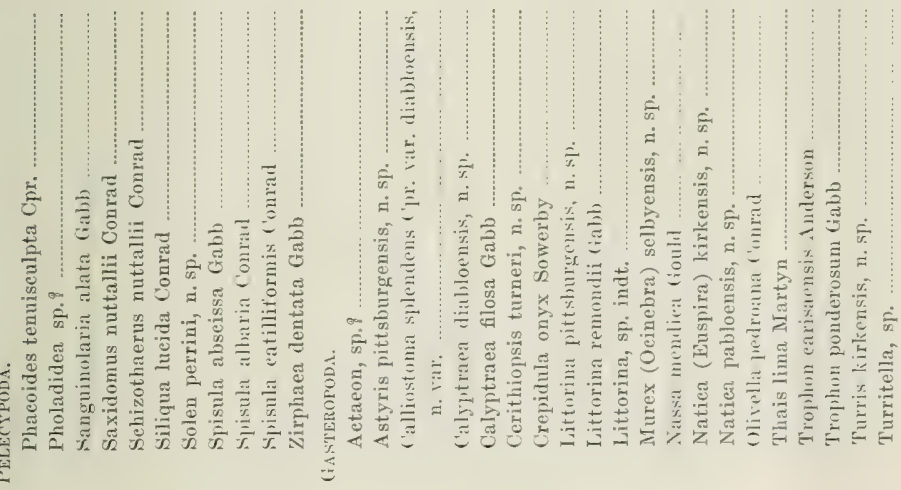




\section{Soutu Side of Mount Diablo}

\section{STRATIGRAPHY AND LITHOLOGY}

The San Pablo Group on the south side of the Mount Diablo anticline has a maximum thickness of about twenty-six hundred feet, as contrasted with the six hundred feet of strata on the north side. Here, as is also true of the group north of the mountain. the beds vary as one follows them along the strike, and only a generalized statement of the section ean be given.

All of the formations on the south side of the mountain dip very steeply; in some places the beds are vertical, and at points along the strike they are even overturned. In the vicinity of Shell Ridge to the east of the torn of Walnut Creek. the Mount Diablo anticline has been overturned toward the southwest and on the south side the San Pablo dips to the north at an angle of about $60^{\circ}$, resting on the Pinole Tuff, which is younger, and is in turn overlain by the Monterey, which is older. The general strike of the beds on the south side of the mountain is about North $50^{\circ}$ West.

Lithology.-The lower fifteen hundred feet of the San Pablo, as measured in the vicinity of Tassajero and Sycamore creeks, are chiefly sandstones. At the base of the section Tassajero Creek cuts through a heavy conglomerate which caunot be followed for any great distance either to the north or to the south. Above these basal conglomerates are about seven hundred and fifty to eight hundred feet of alternating layers of coarse, fossiliferous sandstones, massive, nonfossiliferous sandstones and thin layers of conglomerate. On the north side of T'assajero Creek, and stratigraphically about seven hundred and fifty feet from the base of the group, there is a thin band of greenish-yellow shale. There is an irregular contact between this shale and the coarse, conglomeratic sandstone above. Above the sandstone are about eight hundred feet of medium fine, shaly, gray-brown sandstone.

Above the medium fine, shaly, gray-brown sandstone just mentioned, and about fifteen hundred and fifty feet above the base, is the most persistent shale member of the group; its thickness is about trenty feet and it is continuous for over ten miles. In some localities it contains many impressions of leaves and rushes, suggesting estuarine, brackish, or fresh-water origin. No shells were found, but a study of the fauna above and below the shale strongly suggests that it comes 
at the same horizon as the big shale member in the upper part of the group as described in the San Pablo Bay section.

In the vicinity of Sycamore Cañon, on the south side of the Black Hills, the leaf-bearing shale mentioned above is overlain by a heavy fossiliferous conglomerate, the pebbles of which are composed mostly of andesite. In Syeamore Cañon a well-marked, irregular contact was found between the shale and the conglomerate, with borers of the pholadid type extending from the conglomerate into the shale. This unconformity was noted at two different localities over a mile apart.

The beds above the shale member just described are even more variable than in the lower part of the section, and consist of alternating layers of pearl-gray shale and blne sandstones, together with lenticular beds of conglomerate.

In the vicinity of Tassajero Creek, there is a zone of irregularly bedded conglomerate and sandstone about two hundred feet stratigraphically below the top of the group. The observed thickness of this zone is over fifty feet at several localities. The materials grade rapidly along the strike from sandstone to conglomerate and vice versa. The zone was traced for a distance of over fifteen miles, southeastward from Walnut Creek, but its maximum extension in that direction was not determined. No fossils were found in this zone. The pebbles in the conglomerate are noticeably round and some of them are two to three inches or more in diameter. In the field, they were referred to as the river conglomerates.

On Railroad Ranch, about three miles northeast of the town of Danville and about one mile due south of Wall Point, there is a heavy, well-rounded, non-fossiliferous conglomerate, approximately in the same stratigraphic position as the conglomerate in the vicinity of Tassajero Creek. Lying beneath this is a pearl-gray shale containing an abundance of leaf impressions.

At one locality just below the reservoir on the Mount Diablo road, a well-marked irregular contact appears between the conglomerate and the shale.

Two miles southeast of the torm of Walnut Creek and southwest of Shell Ridge (Concord sheet) there is a non-fossiliferous conglomerate about one hundred and fifty feet below the top of the San Pablo, which at one locality is nearly fifty feet thick, but which rapidly thins out along the strike. This is very much like that seen in the region of Tassajero Creek and south of Wail Point, and probably represents the same zone. 
In generai, the deposits of a large part of the San Pablo in this section may be classed as shallow-water deposits, in part of marine, and in part of estuarine origin. Several unconformities within the group probably indicate emergence and land conditions of short duration at several times during the epoch.

Relation to Monterey Group.-The Monterey Group cannot everywhere be easily separated from the San Pablo, as the beds immediately below and above the contact are quite similar. An irregular contact was located by W. Kew, R. C. Stoner and J. H. Ruckman of the Summer Session field class of 1911 on the south side of the Black Hills near Wall Point. This contact has been taken as the line of division between the two groups. Along this contact bore-holes of the pholadid type were found. A good fauma was not obtained from the upper beds of the Nonterey in this vicinity, but between two hundred and three hundred feet below the contact are the coarse, gray sandstones of the Scutella breweriana beds, which contain a typical fauna of that horizon.

Relation to Pinole Tuff and Orindan.-The San Pablo Group on the south side of Mount Diablo is overlain uneonformably in places by the Pinole Tuff and elsewhere by the Orindan. In the vicinity of the town of Walnut Creek the Pinole Tuff is about two hundred feet thick; it gradually thins out to the south, finally disappearing, and in the vicinity of Tassajero Creek, is replaced by the Orindan which rests directly upon the San Pablo.

Detalled Section of the Sax Pablo Group on the Soutil Side of Motint Diablo as Mieasured in the Vicinity of Tassajero Creek

Orindan Formation. Fresh-water beds.

San Pablo Group, (Uneomformity)

Shaly sandstone FEET Leaf-bearing shale

Hard, bluish sandstone and conglomerate; (zone of "river conglomerate'?)

(Irregular contact)

Leaf-bearing shale

Medium fine sandstone with shaly sandstone toward top

Conglomerate containing Astrodapsis tumidus (Irregular contact)

Leaf-bearing shale

Medium fine sandstone and bands of sanily shale, with Astrodapsis whitneyi, A. tumians, Pinna alamedensis, Trophon lawsoni, ete. 
ECHiNODERMATA.

Astrodapsis tumidus subsp. eierboensis Kew

Astrodapsis tumidus Rémond

Astrodapsis whitneyi Rémond

Scutella pabloensis Kew

Seutella gabbii Rémond

ERUSTACEA.

Balanus, sp.?

PELECYroda.

Arca trilineata Conrad

Cardium corbis Martyn

Cardium quadrigenarium Conrad

Chione diabloensis, n, sp.

Chione pabloensis, n, sp.

Cyrena (Corbicula) ealifornicr, Gabb

Diplodonta orbella Gould

Dosınia arnoldi, n. sp.

Dosinia merriami var, occidentalis, n. var

(i)ycimeris coalingensis Arnold

lijycimeris septentrionalis Midd.

Macoma andersoni, n. sp.

Mreoma diabloensig, n. sp.

Jlacoma nasuta Conrad

liacoma pabloensis, n. sp.

Mncoma sectr Conrad

Hreoma, ef. yoldiformis Cpr.

Macrocallista newcombiana Cpr.

Mactra trampasensis Packard

Metis alta Conrad

Modiolus capax Conrad

Modiolus directus Dall

Hodiolns gabbi, n. sp.

Modiolns merriami, $n$, sp.

Mulinia densata Conrad

Muluni: pribloensis Packard

Myn (Platydon) cancellatus Conrad

Mya dickersoni, n, sp.

Mya (Cryptomya) ovalis Conrad

Mytilus eoalingensis Arnold, n. var.9

Nytilus perrini, n. sp.

Mytilus, sp, indt.

Ostroe bourgeoisii Rémond

Ostrea titan Conrad

Panope generosa Gould

1'aphia, staminea Conrad

l'eeten crassicardo Conrad

['ecten raymondi, n. sp.

L'etricola pabloensis, п. 8p.

Phacoides richthofeni Gabb

Pholas, sp. indt.

Pinna alamedensis Yates

Sanguinolaria alata Gabb

Sanguinolaria nuttallii Conra

Saxidomus nutallii Conrad..

Sehizothaerus puttallii Conrad

Solen perrini, n. sp.

Solen sicareus Gould

Spisula abseissa Gabb

Spisula albaria Conrad

Spisula catilliformis Coñad 
c = 
Mulinia densats Conrad ....
Mthin rebloensis l'ackar

Mt.has (Platydon) eancellatus Conrad

Mysa dickersoni, n. sp. ...............

Mrtilus coalingensis Arnold, n. var.

My tilus perrini, n.

Ostreas bourgeoisii Rémond

Ostrea titan Conrad

Panope generosa Gould

Paphia staminea Conrad ...

Peeten crassicardo Conr

Petricola pabloensis,

Phacoides richthofeni Gabb

Pholas, sp. indt.

Pinna alamedensis Yates

Sanguinolaria nuttallii Conra

Saxidomus nutallii Conrad.

Schizothaerus nuttallii Conrad

Solen perrini, n. sp.
Solen sicareus Gould

Spisula abscissa Gabb

Spisula albaria Conrad ....
Spisula eatilliformis Conra

Spisula, ef. faleata Gould .

Tellina englishi, n. sp.

Tellina pabloensis, n, sp.

Tivela, diabloensis, n.
Tivela gabbi, n. sp.
Vea.

Tivela gabbi, n. sp. .

Venus martini, $\mathrm{L}, \mathrm{sp}$.

Acrea, sp. indt.

Acrmea, вp, indt. ..........

Astralium raymondi, n. sp, ........
Bittium trampasensis, n, sp. .....
Calliostoma biearinatum, n, sp. .

Calliostoma 8 plendens Cpro, var. diabloensis, $\mathrm{n}$, var.

Calyptraea diabloensis, n.

Calyptraen filosa Gabb.

Calyptraen martini, n. Bp.

Chrysodomus buwaldi, n. sp

Chrysoliomus diabloensis, n. B1.
Chrysodomus imperialis Dall

Chrysodomus imperialis D:
Crepidula onyx Sowerby

Crepidula onyx sowerby ....
Crepidula pabloensis, n, в1.

Crepidula pabl.

Nassa pabloensis, n. вp.

Naticn (Euspira) diabloensis, $n, 8$, .

Natica (Euspira) kijrkensis, n, 8p.

Natica (Neverita) arnoldi, n, sp.

Natica (Neverita) pabloensis, n, sp.

Tegula (Chlorostoma) nashi, n. 8 .

Trophon carisaensis Ander
Trophon lawsoni, n. 8p.

1rophon ponderosum Gabb ...................... 
Fine-grained sandstone

Beds made up almost entirely of shells of Mulinia densata

Shaly sandstone; contains Astrodapsis tumidus, subsp. cierboensis, and Astrodapsis pabloensis

Medium-grained, partially laminated sandstone

Conglomerate to pebbly sandstone

Light, massive, fossiliferous sandstone, containing Astrodapsis tumidus subsp. cicrboensis, Scutella pabloensis, Mytilus coalingensis, n. var. $9 \quad 250$

Massive, medium-grained sandstone

Coarse sandstone and bands of fine eonglomerate $\quad 100$

Massive sandstone and heavy eonglomerates $\quad 50$

Coarse, soft sandstone

Coarse-grained sandstones with minor bands of conglomerate; Scutella gabbii zone

Conglomerate, pebbles small and rounded

(Unconformity ?)

Monterey Group.

Scutella breweriana zone, mostly coarse conglomeratic sancistone.

\section{FAUNA}

The two major faunal zones found in divisions $\mathrm{A}$ and $\mathrm{B}$, of the San Pablo Bay section are also recognizable in the San Pablo group on the south side of Mount Diablo. In the section in the vicinity of Tassajero Creek there appears to be no marked lithologic change or stratigraphic break between the two zones, but there is a very marked difference hetween the faumas below and above a line which lies about 1400 feet above the base. Below this line Astrodapsis tumidus subsp. cierboensis, Scutella pabloensis, Mytilus coalingensis, n. var.? Spisula abscissa, Chrysolomus pabloensis and Calyptraea diabloensis are some of the most common forms. Above this line and separated from the lower fauna by only a few feet, Astrodapsis tumidus, Astrodapsis whitneyi, Pinna alamedensis, Mulinia densata, Trophon carisacnsis are found in abundance.

The beds, in which the lower fauna is found, are here designated as division $\mathrm{A}$ and those containing the upper fauna as division $\mathrm{B}$.

Division A.-The fauna of division $\mathrm{A}$ is divisible into two minol zones, which are correlated with the two lower minor faunal zones of division $\mathrm{A}$ of the San Pablo Bay section. Here also the division is made on the basis of the sea-urchins. At the base of the group Scutella gabbii is found; stratigraphically only a little above this. Scutella gabbii disappears and Astrodapsis tumidus subsp. cierboensis 
appears. This species is found through a large part of division $\mathrm{A}$. The third minor faunal zone deseribed from division $\mathbf{A}$ of the San Pablo Bay section has not been recognized in any other section.

The species associated with Astrodapsis tumidus, subsp. cierboensis both here and in the San Pablo Bay section, believed to be characteristic of division A, are Scutella pabloensis, Mytilus coalingensis Arnold, n. var.?, Spisula abscissa, Tivela diabloensis, Chrysodomus pabloensis. One of the most common species found in this zone and one which is believed to be at least locally charaeteristic of it, is Mytilus coalingensis, n. var? It occurs with an assemblage of species very similar to that with which it is found on the north side of the mountain. Some of these species are Macrocallista newcombiana, Macoma nasuta, Ostrea bourgeoisii, Paphin staminea, Pecten crassicardo, Pecton raymondi, Saxidomus muttallii, Schizothaerus nuttallii, and Calyptraea diabloensis.

Division B.-From the 200 to 300 feet of sandstones just beneath the lowest and most persistent leaf-bearing shale of the Sycamore and Tassajero Creek sections, a very good fauna was obtained, inchuding two species of sea-urchins, Astrodapsis whitncyi and Astrodapsis tumidus, and many mollusks. Some of the common mollusks are Chione pablocnsis, Cryptomya ovalis, Dosinia arnoldi, Dosinia merriami var. occidentalis, Macoma secta, Macoma nasuta, Macoma andersoni, Modiolus gabbi, Modiolus directus, Mulinia densata, Pecten raymondi, Pecten crassicardo, Pinna alamedensis, Tenus martini, Astralium raymondi, Natica (Neverita) pabloensis, Cancellaria pabloensis, Trophon carisaensis, and Trophon lawsoni. Mulinia densata makes its first appearance in these lower sandstones of division B, a fact worthy of especial note. This species has not been found in the lower part of any section of the San Pablo group in this part of the state. One bed two or three feet thick in these sandstones is made up almost entirely of the shells of this species, and the layer is persistent for a number of miles along the strike.

The typical Astrodapsis whitneyi was not found in the beds just above the lowest shale member of the Tassajero or Sycamore Cañon sections. The fanna found above this shale, though not large, includes a number of speeies that have not been found below the shale. Of these Tivela gabbi and Vassa pabloensis may prove to be characteristic of the upper part of the group.

In the Walnut Creek section on the west side of Shell Ridge there was found at one horizon a fairly large fauna. In this vicinity (Shell Ridge) the lower part of division $B$ is composed of fairly coarse sand- 
stones about 100 feet in thickness. This is overlain by a fine, white, tuffaceous shale, which is approximately seventy-five feet thick. Many leaf impressions are contained in the shale, and, toward the top, Cyrena californica, Mytilus perrini and Macoma pabloensis were found, suggesting that these deposits were either of brackish-water or estuarine origin.

Above the shale is about two hundred feet of medium-grained, blue sandstones containing Astrodapsis whitnoyi, associated with a very meagre fauna. Above the Astrodapsis whitnoyi beds is a horizon of conglomerate, followed by massive gray sandstones and shaly sandstones. Some of the most important fossil localities in the sandstones and conglomerates are 1942, 1947, 1948 and 1950. The most common species are Astrodapsis tumidus, Glycimeris coalingensis, Tivela gabbi and Mulinia densata. Some of the species in this zone that have not been found associated with Astrodapsis uhitneyi, are Chione diabloensis, Macoma diabloensis, Tivela gabbi, Astralium raymondi, Calliostoma bicarinatum, Crepidula pabloensis and Nassa pabloensis. Some of the species in the Astrodapsis whitneyi zone, that have not been found associated with the fauna mentioned above, are Astrodapsis whitneyi, Tenus martini, Chione pabloensis, Dosinia merriami var. occidentalis, Tellina englishi, Cancellaria pabloensis and Trophon lausoni.

There are good reasons for believing that the two minor faunal zones just described are also represented in the San Pablo Bay section.

The assemblage of species in the most fossiliferous zone above the shale is very similar to that in the beds just above the Astrodapsis whitneyi zone of Shell Ridge. Tivcla gabbi is present with a number of other species which have not been found associated with Astrodapsis whitneyi in the Mount Diablo section, but are found in the horizon above. The evidence for the correlation of the beds below the shale of the Bay Section with the Astrodapsis whitneyi zone of the Mount Diablo section is not so good. Astrodapsis whitneyi has not been found in that section, but the species Trophon lawsoni, which has been found only in the Astrodapsis whitneyi zone on the south side of Mount Diablo, is present.

In the Shell Ridge section the beds above the so-called river conglomerates have not yielded many fossils, but farther to the south, in the region of Pine Cañon, a few species that may prove to belong to a minor faunal zone were collected near the top of the series. These arr Astrodapsis tumidus large variety, Iytilus merriami and Trophon ponderosum var. pabloensis. The meagreness of the fauna from thesp 
beds makes it unsafe to generalize as to its distinctness. The localities from which this famna was obtained are nos. 104,118 , and 1499 .

In general, division B of the San Pablo group on the south side of the Mount Diablo anticline presents three minor faunal zones. The faunas of the two lower zones, though similar, each contains a number of species not common to the other. These two zones are probably also represented in the San Pablo Bay section. In both sections there is a change in the character of the deposits along the line of the division of the zones.

The third minor faunal zone, which so far has yielded only a meagre fauna, has not been certainly recognized outsile of the section on the south side of MLount Diablo.

\section{Rocky Ridge}

A very interesting section of the San Pablo Group is seen on the south side of Rocky Ridge near the southeast corner of the Concord quadrangle. Here the thickness of the group is roughly estimated to be twenty-four hundred feet.

\section{STRATIGRAPHY AND LITHOLOGY}

Relation of San Pablo to Monterey Group.-The beds of the upper Monterey (Scutella breweriana zone) outerop along the main crest of the ridge, where the species Scutclla breweriana is found in abundance. The lower Monterey of this section has been faulted away and the coarse gray sandstones of the Scutella breweriana zone rest with a fault contact against the Orindan, which belongs to the Las Trampas Ridge section just to the north. The upper Monterey is lithologically similar to that seen on the south side of the Mount Diablo anticline and in the vicinity of the town of Walnut Creek. Above the coarse sandstones of the Scutella breweriana zone are about five hundred feet of medium fine, buff to yellow-brown and gray sandstone in which is found a fauna typical of that in the fine sandstones oceupying the same stratioraphic position on San Pablo Bay. Above the fine sandstones of the Monterey comes a series of coarse, massive layers of gray sandstone referable to the San Pablo and similar to the sandstones which characterize the lower San Pablo everywhere in this general region.

The beds of both the San Pablo and Monterey Gromps have practieally the same strike and dip throughout and so far as could be 
determined, the coarse, basal sandstones of the one grade downward into the medium fine sandstones of the other. Here again is a section in which no structural break has been found separating the San Pablo from the upper Monterey.

Lithology.--The coarse, massive, non-fossiliferous sandstones of the basal San Pablo outerop as jutting ledges along the high, nearly perpendicular eañon walls. These sandstones are followed above by a series of fine and coarse sandstones, with several interbedded layers of fine conglomerate, which yielded fossils at two levels.

A noteworthy feature of the San Pablo in this area is the presence of small lenticular beds of limestone near the middle of the group; two outcrops were found, both approximately at the same stratigraphic position. At one locality near the south end of Section 35, T $1 \mathrm{~S}, \mathrm{R}$ $2 \mathrm{~W}$, Mount Diablo base line, there is an outerop of the limestone which is less than a quarter of a mile in length, and from a maximum thickness of eight feet it thins rapidly in both directions. The limestone grades downward into a muddy shale and sandstone and is overlain by a considerable thickness of fine gravel. No difference in dip or strike of the beds above and below the lens could be detected. Some of the limestone is pure white and of a very fine, porcelaneous texture, fracturing conchoidally like flint, and some of it is more impure and of a darker color. No shells were found, but the impressions of leaves and rushes are very abundant.

The other limestone locality is near the sonthwest corner of Section 5, T $2 \mathrm{~S}, \mathrm{R} 1 \mathrm{~W}$, Mount Diablo base line, about one and a half miles southeast of the first locality.

The question arises-Under what conditions were the beds of this character deposited? The presence of great quantities of dicotyledonous leaves and rushes shows conclusively that the limestones are not of typical marine origin. These limestones closely resemble those of fresh-water lake deposits, but it is not certain that they could not be formed under estuarine conditions. Limestones lithologieally almost identical with those found in the San Pablo oceur in the overlying Orindan in this same section. That these upper limestones are of lacustral origin is shown by the fresh-water shells which they contain.

The beds above the limestone lenses in the San Pablo are mostly medium fine sandstones with occasional subordinate layers of shale similar to the leaf-bearing shale seen in the section on the south side of the Mount Diablo anticline. 
In this region, the Orindan rests directly on the San Pablo, the Pinole Tuff being absent.

\section{FAUNA}

The fauna found below the limestone on Rocky Ridge is to be correlated with that of division $\mathrm{A}$ of the San Pablo Bay section and of the Mount Diablo section. Scutella gabbii and Astrodapsis tumidus subsp. cicrboensis have not been found here, but in the section on Las Trampas Ridge, about a mile to the north, these two species occur in their proper stratigraphic sequence. On Rocky Ridge the following species were foumd below the limestone, and are believed to be characteristic of the lower San Pablo: Spisula abscissa, Hytilus coalingensis, $\mathbf{n}$. var? and Ostrea bourgeoisii.

Above the limestone, a fairly large fauna was obtained associated with Astrodapsis whitnoyi. Some of these are Amiantis dalli, Cyrena californica, Mytilus trampasensis, Iytilus perrini, Macoma pabloensis, Mya dickersoni, Venus martini, Cancellaria pabloensis, Tatica (Neverita) arnoldi, Trophon carisaensis. See localities 38, 39, 41 and 1224 .

\section{Tice Valley Syncline}

\section{STRATIGRAPHY AND LITHOLOGY}

A good section of the San Pablo is found north of Las Trampas Ridge in the vicinity of Tice Valley, Contra Costa County, where it is a little over twenty-one hundred feet thick. The beds outcrop on both sides of a syncline, and are overlain by the Pinole Tuff and the Orindan Series,

Relation of San Pablo to IIonterey Group.-In this section the San Pablo apparently grades downward into the Monterey, the beds of the two formations having the same dip and strike. The upper Monterey is composed of medium fine, yellow-brown sandstones, which are very much like those of the upper Monterey of the Rocky Ridge section.

Lithology. - On account of insufficient collecting localities in this area no attempt has been made to draw a definite line, corresponding to that between division $\mathrm{A}$ and $\mathrm{B}$ on the south side of Mount Diablo or on the bay. 
The section is of interest because of its contrast to the Mount Diablo section which lies only a few miles to the east, these beds being made up almost entirely of sandstones, with little or no shale. Conglomerates and leaf-bearing shales such as are common in the Mount Diablo section are lacking. The probable reason for the uniformity of these beds is that they were deposited farther away from the shore line. During much of San Pablo time the shore line was near the present site of Mount Diablo and these slight oscillations would have markedly affected the character of the depositions from time to time. A few miles to the west, in deeper water, the same changes in level would not have appreciably affected the uniform processes of sedimentation. The estuarine deposits of the San Pablo in the vicinity of Mount Diablo were undoubtedly formed in close connection with the shore line.

The beds in the lower four hundred feet of this section consist of fairly hard, coarse, fossiliferous sandstone, alternating with medium coarse massive sandstones. They are lithologically similar to the basal beds of the series on San Pablo Bay. In ascending order above the coarse sandstones are about six hundred feet of medium fine to medium coarse, fairly homogeneous sandstones; seven hundred feet consist of fairly coarse, gray sandstones, some layers of which are fossiliferous; about 300 feet of fine, dark brown to gray sandstones; and about 75 feet of coarse, tuffaceous sandstone. The San Pablo is overlain by the Pinole Tuff and the Orindan series.

\section{FAUNA}

Scutella gabbii was found at the base of the section. A little above the base, Astrodapsis tumidus, subsp. cierboensis was obtained, associated with Tivela diabloensis. Abont one thousand feet above the base, Astrodapsis tumidus and Astrodapsis whitneyi were collected from a zone which at localities 1121 and 1127 yielded a fairly large fauna. An upper San Pablo fauna was obtained at locality 2329. Macoma andersoni, one of the common species at this locality, is thought to be characteristic of the zone above the Astrodapsis whitneyi beds on the south side of Mount Diablo, and this zone is supposed to be equivalent to the very fossiliferous horizon just above the shale in the bay section. 


\section{OTHER LOCALITIES}

Other localities in Contra Costa county from which fossils of San Pablo age listed in this paper were obtained are Las Trampas Ridge, Lafavette Ridge, and southwest of Danville.

Las Trampas Ridge.-Las Trampas Ridge lies less than a mile east of and parallel to Rocky Ridge. The San Pablo outerops on the south side of the ridge and dips to the southwest at an angle of $60^{\circ}$ to $70^{\circ}$; it rests upon the Monterey with relations analagous to those observed on Rocky Ridge. The two major fammal zones of the San Pablo are recognized here. Scutella gabbii is found at the base of the group, and Astrodapsis tumidus, subsp. cierboensis and other characteristic lower San Pablo species oceur at a slightly higher level. A very good upper San Pablo fauna was obtained near the top of the group at locality 1182 .

Lafayette Ridge.-A few localities including Nos. 145, 149, 1195, and 1197 , are listed from Lafayette Ridge, which is practically a continuation of the section on the north side of the Tice Valley syncline; the two major faunal zones are recognized here.

Danville.-San Pablo outerops occur on the north side of Las Trampas Ridge a short distance southwest of Danville, but the section is obscure. C. E. Weaver listed several species from one locality which the writer has also visited. A typical San Pablo fauna, including two new species of gasteropods, Tegula (Chlorostoma) trampasensis and Leptothyra danvillensis, was obtained here and is listed under localities 1635 and 1636.

\section{COMPLETE LIST OF KNOWN SPECIES FROM THE SAN PABLO GROUP OF MIDDLE CALIFORNIA, WITH THEIR GEOLOGIC RANGE}

The following is a complete list of the species from the different sections described in this paper. The different zones in which the species occur are indicated in the columns. With the exception of the collections belonging to the University of Califormia, the chief sources of information in regard to the species common to the San Pablo, Santa Margarita, Jacalitos and Etehegoin, have been Dr. J. P. Smith's" paper on the "Geologic Range of Miocene Invertebrate Fossils of California" and the collections of the California Academy of Sciences in San Franciseo.

23 Proc. Calif. Acad. Sei., 4th series, vol. 3, pp. 161-182. 
EcH

EL]

C

(

c

I

$\times$

$x \times$

1

!

: $x$

: $\times$

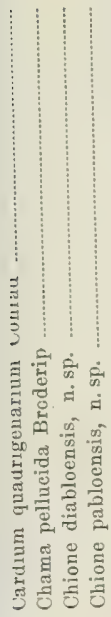


Astrodspsis tumidus, subsp. cierboensis Kew Astrodapsis tumidus Rémond

Astrodapsis whitneyi Rémo

\section{Perectpoda.}

Amiantis dalli, n. sp.

Cardium quadrigenarium Conrad

Cyrena (Corbicula) californica Gab

Glycimeris septentrionalis Mide

Macoma andersoni, n. 8

Macoma nasuta Conrad

Macoma pabloensis, $n$.

Mactra trampasensis Packard

Modiolus directus Conrad

Modiolus directus Conra

Mulinia densata Conrad

Mulinia pabloensis Packar

Mya dickersoni, n, sp.

Mya (Cryptomya) ovalis Conrad

Mytilus perrini, n. sp.

Mytilus trampasensis, n. Bp.

Ostrea bourgeoisii Rémo

Ostrea titan Conrad ...

Paphia staminea Conrad

Pecten crassicardo Conrad

Pecten estrellanus Conrad

Pecten raymondi, $\mathbf{n}$. sp.

Pecten pabloensis Conrad

Pinna alamedensis Yates

Pinna, sp. indt.

Spisula abscissa $\mathrm{Gabb}$

Saxidomus nuttallii Conrad

Scbizothsorus nuttallii Conrad

Siliqua lucida Conrad

Solen perrini, n. sp.

Spisula catilliforrais Conrad

Spisula albaria Conra

Tivela gabbi, n, sp. ....

Tivela diabloensis, n. вp.

Venus ma
OAstropoda.

Astralium raymondi, $\boldsymbol{r}_{\text {, }} \mathrm{Bp}$.

Bittium trampasensis, $\mathrm{n}$, sp.

Bursa trampasensis, n, sp

Calliostoma bicarinatum, n, sp

Calyptraea diabloensis,
Calyptraea flosa $\mathrm{Gabb}$

Calyptraea filosa Gabb

Calyptraea inornata Gabb

Cerithiopsis bolingerensis, n. sp

Chrysodomus pabloensis, n. sp.

Columbella (Astyris), ef. tuberosa Cpr

Crepidula adunea Sowerby

Gardinia reticulata Sowerby

Leptothyra pabloensis, n. sp.

Murex (Ocinebra) dalli, ns

Nassa pabloensis, n. sp.

Natica (Euspira) kirkensis, n. sp.

Natica (Neverita) arnoldi, n. sp.

Natica (Neverita) pabloensis, n, sp. ...

Tegula (Chlorostoma) danvillensis, n. sp.

Thais lima Martyn

Trophon carisaensis Anderson

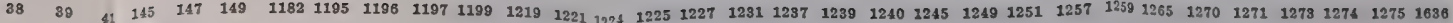


วแนว0аN

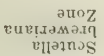

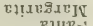

вาurs

ofqued urs
dasin'

olqua uss

$x$ ad

sol!letef

แกตรมขว

ข0सारन $<\times \times \times \times \times \times \times-x$

星

ไนววมน
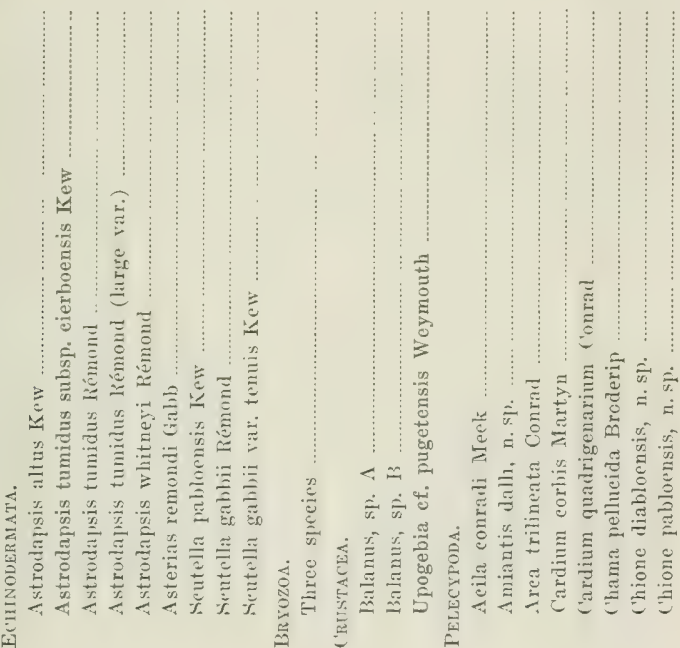

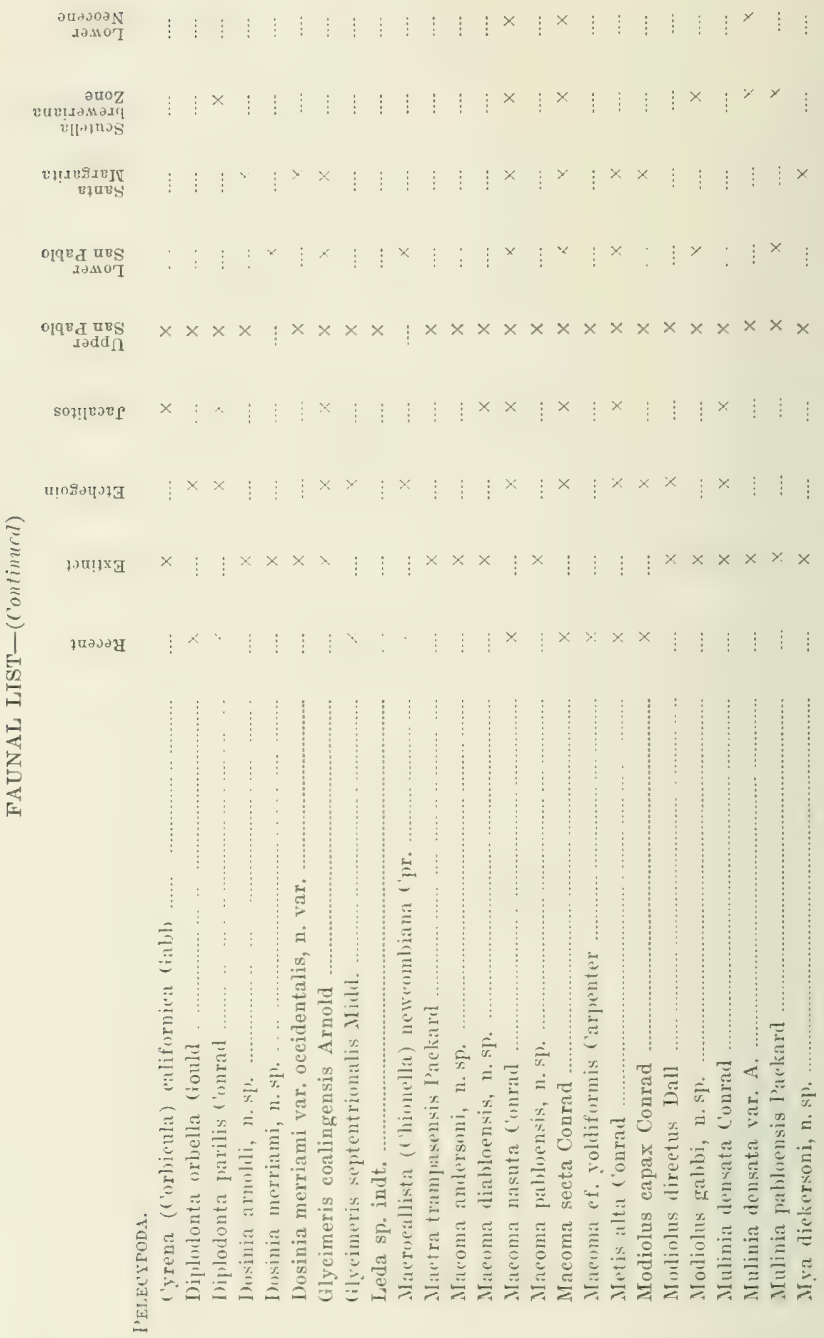


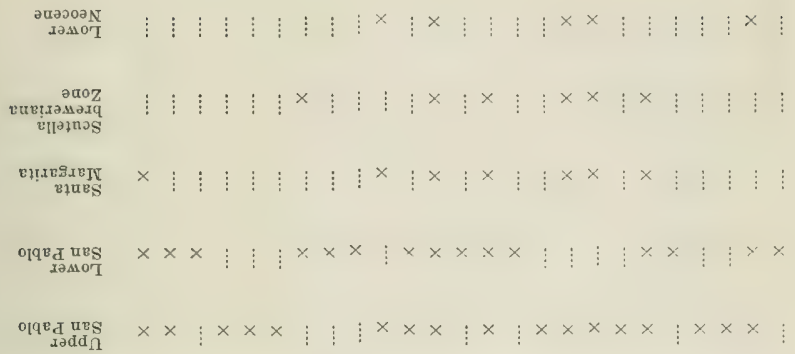

Sol!feref

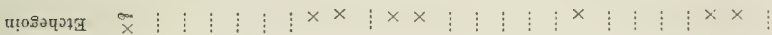

ฮี

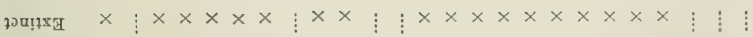

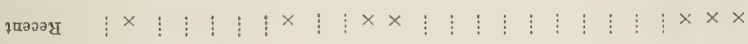

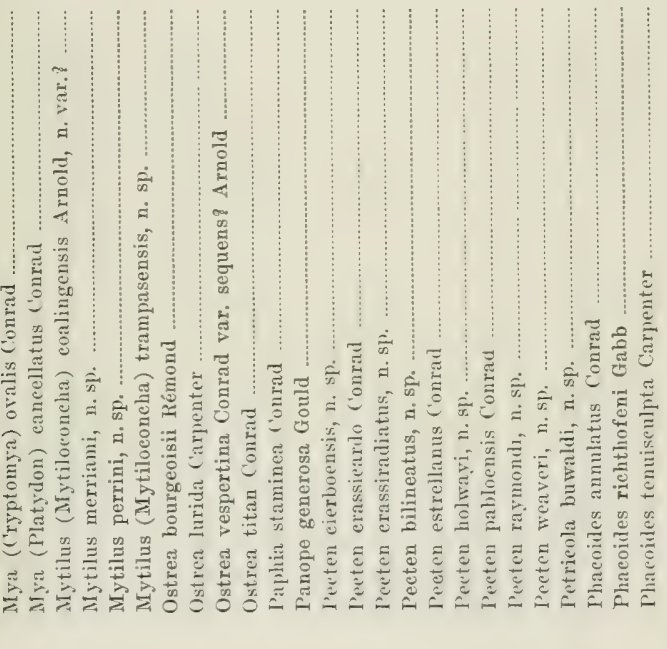




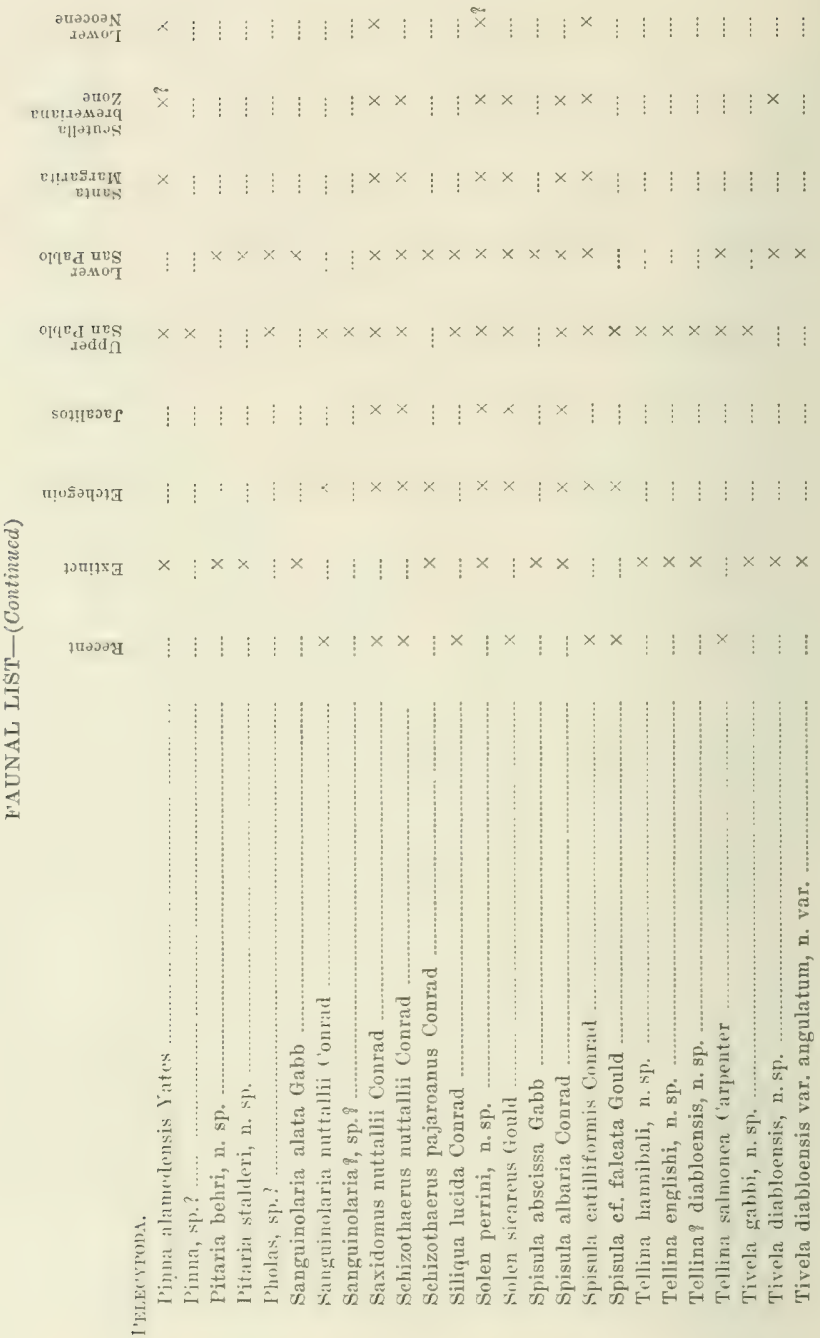



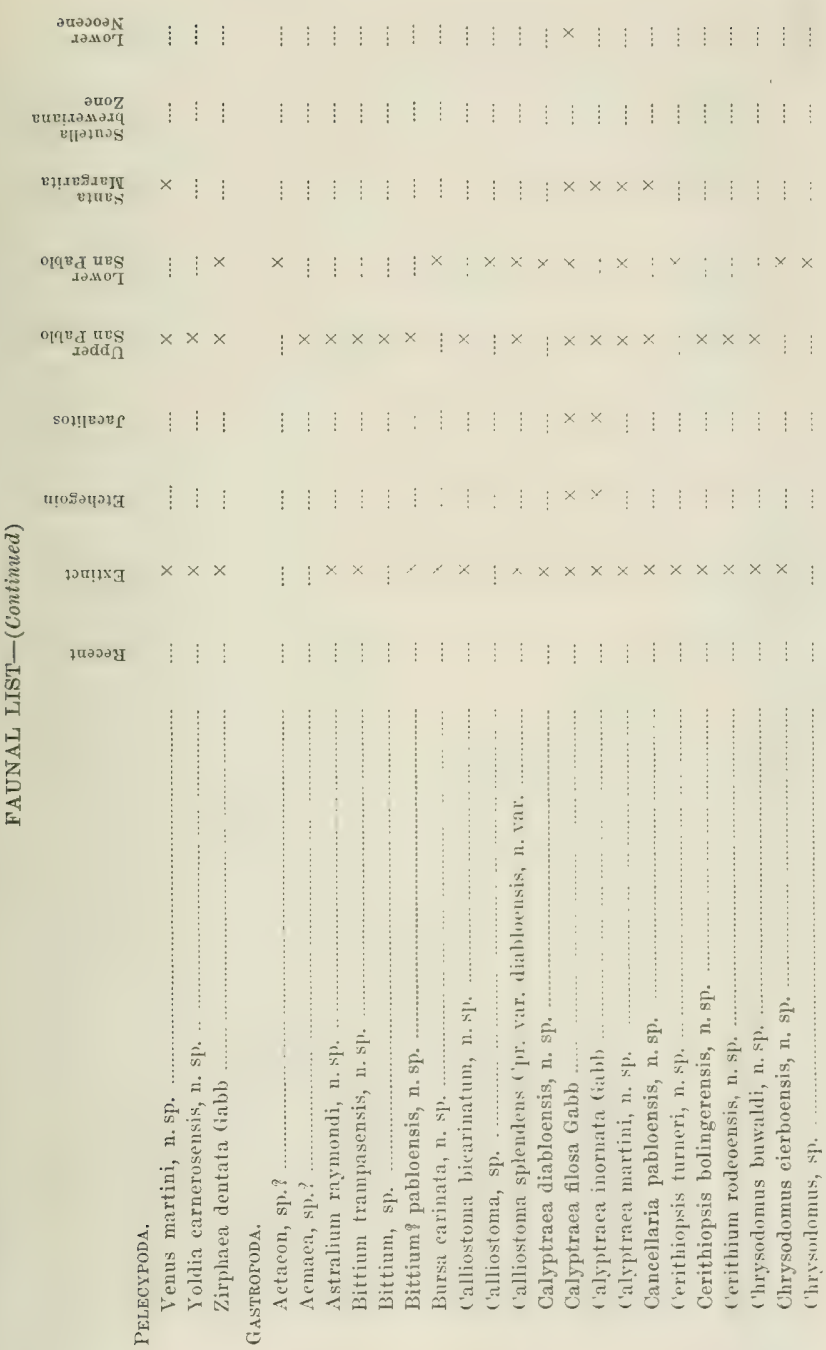


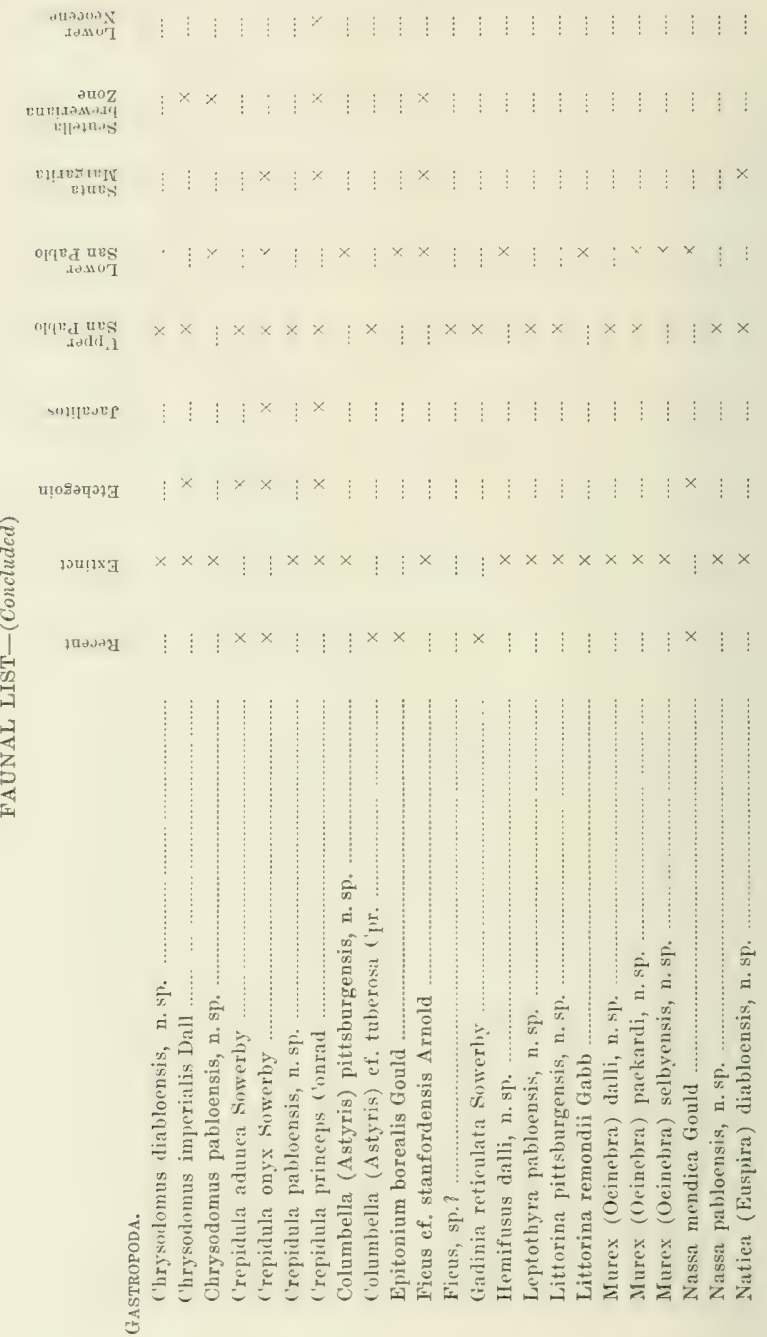




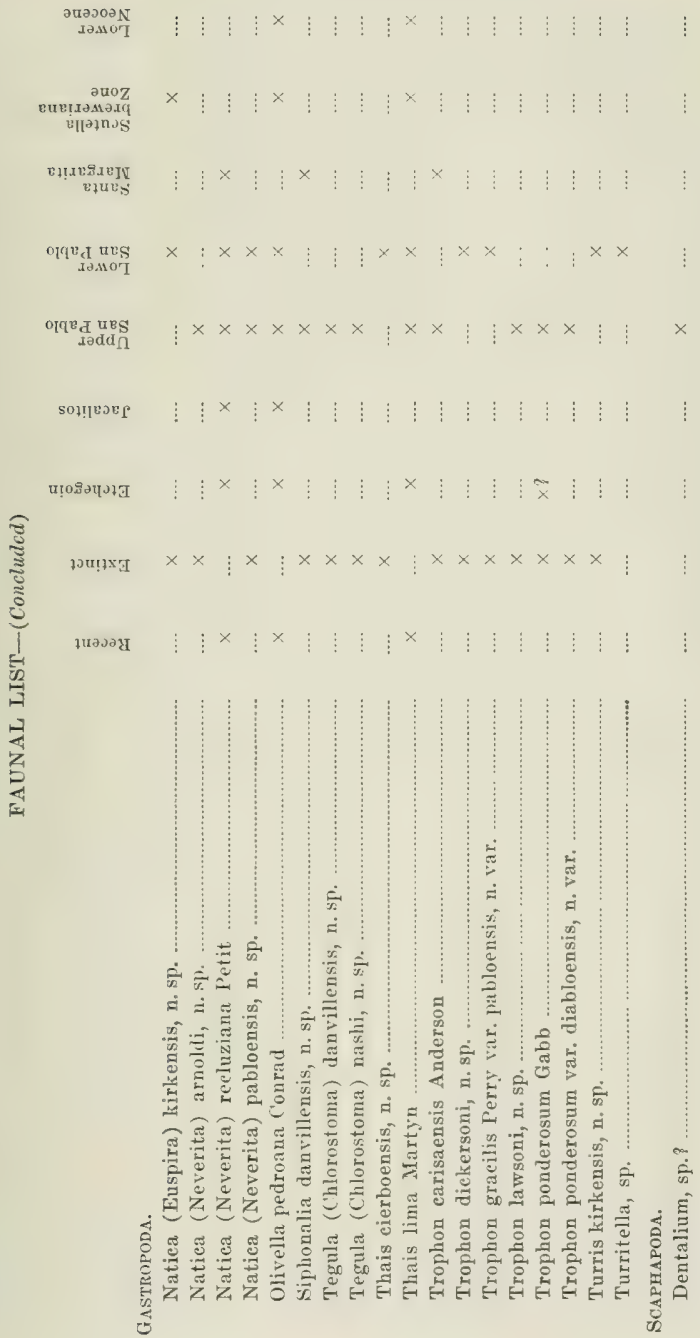




\section{SUIIIARY OF FAUNAL LIST}

Eehinodermata

Pelecypoda

Gastropoda

Bryozoa

Crustacea

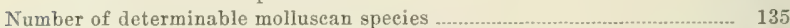

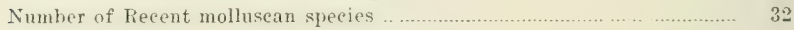

Percentage of Recent molluscan species to total of mollusean and echinodern species

Percentage of Recent mollusean species to total molluscan fauna .

Percentage of Recent gastropod species in determinable gastropod fauna

Number of echinoderm and mollusean species in Lower Major faunal zone

Number of echinoderm and mollusean species in Upper Major faunal zone

Number of species common to San Pablo and Scutella breweriana zone....

Number of species common to San Pablo and Santa Margarita of south.

Number of species common to San Pablo and Etchegoin-Purissima Horizon and including all Recent species found in the former which have not been found in the latter

Number of species common to the San Pablo and the Lower Neocene. (Includes "Temblor, Vaqueros and Monterey," not Scutella breweriana zone).

Number of new species and rarieties described

\section{STINATARY OF EVIDENCE FOR FACNAL ZONES IN SAN PABLO GROUP}

T'wo major faunal zones are recognizable in every section described and in each are minor faunal zones. The minor faunal zones are established on the following evidence: (1) Scutella gabbii is common in the lower San Pablo in nearly every section known. The species is not limited to the lower beds, however, as was formerly believed, for oceasional specimens have been found at several localities well above the middle of the group. (2) Astrodapsis tumidus subsp. cierboensis first appears a little above the base and ranges well up toward the middle of the group; associated with it is Scutella pabloensis. Astrodapsis tumidus and Astrodapsis whitneyi are first found near the middle of the group. On the south side of Mount Diablo the latter 
appears to be restricted within a thickness of about two hundred and fifty feet of strata; and this part of the section is desiguated the Astrodapsis whitneyi zone. Astrodapsis tumidus ranges well up toward the top of the group. (4) On the south side of the MIount Diablo anticline, the beds immediately above the Astrodapsis whitneyi zone and above the lowest persistent shale of division $B$ of that section, contain a few molluscan species which may prove to be characteristic of this horizon. At a few localities on the south side of Mount Diablo (in the upper beds of the San Pablo, above the so-called river conglomerates), a still higher minor faunal zone is indicated by the presence of a large variety of Astrodapsis tumidus.

The two major faunal zones in the series are separable not only on the basis of the sea-urchins, but also on the basis of the mollusean fauna. There are some differences between the molluscan faunas in some of the minor faunal zones as has been shown in the deseription of the fauna from the south side of the Mount Diablo anticline; those differences, however, are not so great or well founded as those between the two major zones.

The following species present in the lower zone have not been found in the upper zone, or in any other formation stratigraphically above the San Pablo. Those marked with an asterisk have not been found in more than one section.

\footnotetext{
Seutella pabloensis Kew.

Astrorlapsis tumidus subsp. cierboensis Kew

*Asterias remondi Gabb.

Dosinia merriami, n. sp.

Mytilus coalingensis Arnold, n. $\operatorname{var}$ ?

Ostrea bourgeoisii Rémond.

*Pecten cierboensis, n. sp.

*Pecten weaveri, n. sp.

*Pitaria behri, n. sp.

*Pitaria stalderi, n. sp.

Sanguinolaria alata Gabb.

Spisula abscissa Gabb.
}

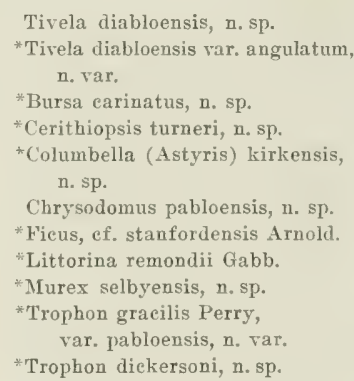

The following species from the upper major faunal zone have not been found in the lower zone and have not been reported from any formation above the San Pablo group. Those marked with an asterisk have not been found in more than one section. 
Astrodapsis tumidus Rémond.

Astrodapsis whitneyi Rémond.

* Acila conradi Meek.

Amiantis dalli, n. sp.

*Chione pabloensis, n. sp.

"Chione diabloensis, n. sp.

Cyrena (Corbicula) californica Gabb.

Mytilus perrini, n. sp.

Mytilus trampasensis, n. sp.

Ostrea titan Conrad.

Pecten bilineatus, n. sp.

*Pecten holwayi, n. sp.

Pecten pabloensis Conrad.

Pinna alamedensis Yates.

"Pinna, sp. indt.

*Sanguinolaria? sp.

${ }^{\prime}$ Tellina englishi, $\mathrm{n}$. sp.

*Tellina pabloensis, n. sp.

Tivela gabbi, n. sp.

Venus martini, n. sp.

Astralium raymondi, n. sp.

"Bittium pabloensis, n. sp.

Bittium trampasensis, n. sp.

Cerithium rodeoensis, n, sp.

*Cerithiopsis bolingerensis, n. sp.
Dosinia arnoldi, n. sp.

Dosinia merriami var, occidentalis, n. var.

Macoma äiabloensis, n, sp.

Macoma andersoni, n. sp.

Mulinia densata Conrad var. A.

Calliostoma bicarinatum, n. sp.

Calliostoma splendens var, diabloensis, n. var.

Cancellaria pabloensis, n. sp.

*Chrysodomus buwaldi, n. sp.

*Chrysodomus diabloensis, n. sp.

*Leptothyra pabloensis, n. sp.

* Littorina pittsburgensis, n. sp.

Murex (Ocinebra) dalli, n. sp.

Nassa pabloensis, n. sp.

Natica (Neverita) arnoldi, n. sp.

"Tegula (Chlorostoma) danvillen sis, n. sp.

Tegula (Chlorostoma) nashi, n. sp.

Trophon carisaensis Anderson.

Trophon ponderosum Gabb var. diabloensis, n. var.

Trophon lawsoni, n. sp.

The lists show that the lower major faunal zone contains fewer characteristic species than the upper. In almost every section deseribed, the collecting in the lower zone is not so good as in the upper. It would not be safe to conclude finally as to the distinctness of the two faunas, for more thorough collecting in the future may prove a greater range for some of the species now regarded as characteristic of one or the other of the zones.

The following species common in the upper and lower zones have not been found in beds younger than the San Pablo Group:

Seutella gabbii Rémond.

Modiolus gabbi, n. sp.

Mulinia pabloensis Packard.

Pecten erassieardo Conrad.

Pecten raymondi, n. sp.
Zirphaea dentata Gabb.

Murex (Ucinebra) packardi, n. sp. Natica (Neverita) pabloensis, n. sp. 


\section{RELATION OF SAN PABLO FAUNA TO RECENT FAUNA}

A noticeable feature of the San Pablo fauna is the close genetic relationship of many of its extinet species to the Recent fauna of the Pacific Coast. Every such species is related to a form now living in the same geographical province as that in which the fauna of the San Pablo would be found if it were living at the present day. Below are lists of the extinct species and the Recent species to which they are obviously closely related.

Extinct
Acila conradi Meek.
Amiantis dalli, n. sp.
Chione diabloensis, n. sp.
Chione pabloensis, n. sp.
Macoma andersoni, n. sp.
Macoma diabloensis, n. sp.
Tellina englishi, n. sp.
Tivela gabbi, n. sp.
Tivela diabloensis, n. sp.
Astralium raymondi, n. sp.
Columbella (Astyris) kirkensis,
n. sp.
Calliostoma splendens var. dia.
$\quad$ bloensis, n. var.
Leptothyra pabloensis, n. sp.
Littorina pittsburgensis, n. sp.
Murex (Ocinebra) dalli, n. sp.
Murex (Ocinebra) selbyensis, n. sp.
Natiea (Euspira) kirkensis.
Natiea (Neverita) pabloensis.
Tegula (Chlorostoma) nashi, n. sp.

\author{
Recent \\ Acila castrensis Hinds \\ Amiantis callosa Conrad. \\ Chione simillima Sowerby. \\ Chione simillima. Sowerby. \\ Macoma indentata Cpr. \\ Macoma nasuta Conrad. \\ Tellina jdaea Dall. \\ Tivela stultorum Mawe. \\ Tivela stultorum Mawe. \\ Astralium undosa Wood. \\ Columbella (Astyris) gausapata \\ Gonld. \\ Calliostoma splendens Carpenter. \\ Leptothyra carpenteriana \\ Pillsbury \\ Littorina planaxis Nuttall. \\ Murex (Ocinebra lurida) \\ Middendorf. \\ Murex (Ocinebra lurida) \\ Middendorf. \\ Natica (Euspira) lewisi Gabb. \\ Natica (Neverita) recluziana Petit. \\ Tegula (Chlorostoma) aureatinc- \\ tum Forbes.
}

\section{TEMPERATURE CONDITIONS OF SAN PABLO SEA}

We may judge of the temperature of the waters of the San Pablo sea from the present geographical range of the Recent species in its fauna. With this as a criterion, the waters of that sea were of about the same temperature as the waters of the present coast between Point Conception and Santa Barbara. According to Philip P. Carpenter, ${ }^{24}$ the temperature of these waters is about the same as those of the 1856.

24 "Mollusea of the West Coast of North America," Brit. Assoc. Rep., p. 167, 
Mediterranean Sea, and should be classed as middle temperate. Twenty-nine Recent species are known from the San Pablo and of these eighteen range as far south as San Diego.

We may conclude therefore that the fauna of the San Pablo lived under fairly warm temperate conditions.

\section{CORRELATION}

For the purpose of this paper the writer considers the Neocene section of California to he divisible into Lower, Middle, and Upper Neocene. The Lower Neocene as used here includes the "Vaqueros," "Temblor," and "Monterey;" the Middle Neocene includes the San Pablo Group (including the Santa Margarita of the southern part of the state); the Upper Neocene includes the Etchegoin, Purissima, Merced, Fernando, Wildeat, and the Pliocene deposits at San Diego and San Pedro.

\section{Previous Contributions}

Before the position of the San Pablo in the marine Neocene section of California is discussed, the writer will briefly review the papers which contain data concerning the correlation of the San Pablo.

No attempt was made by the early palaeontologists, Gabb, Conrad, Cooper and others, to divide the Upper and Middle Neocene of California into definite faunal zones. Even as late as 1895 little was known about the faunal zones in the Upper and Middle Neocene.

G. H. Ashley, ${ }^{25}$ in a paper entitled, "The Neocene Stratigraphy of the Santa Cruz Mountains in California," included all the Upper Neocene of that area in the Merced Series. The base of the series was believed to be close to the border line between Miocene and Pliocene. Ashley recognized that in going from the bottom to the top of the Nerced series there was a change in the fauna. The fauna from the base of the series was believed to be more closely related to the Miocene than to the Pliocene, and these lower beds were ealled transitional beds. On page 330 , in speaking of these transition beds, he says:

It would therefore seem that the lowest, or what might be called the Pecten beds, are more closely related to the Miocene, but a rapidly changing fauna soon gives the beds a Plincene aspect which is maintained through most of the section.

2s Proc. Calif. Acad. Sci., 2nd series, vol. 5, pp. 273-365, 1895. 
Ashley did not separate the fauna of the transition beds from that of his typical Pliocene beds. That he believed his Merced series represented the entire Upper and Middle Neocene is shown by the following quotation from page 322 of the paper just cited:

It seems possible that most of the beds from which the older Pliocene have been reported will be found to correspond to this series. Thus the fauna from Kirkers Pass and Green Valley, Contra Costa County, Santa Rosa and Russian River, Sonoma County, would suggest the presence of the Merced series.

Dr. J. C. Merriam, ${ }^{26}$ in a paper on the Neocene sea-urchins of California, appears to have been the first person to recognize two distinct faunal zones above what is here designated Lower Neocene. He points out that the. San Pablo is without doubt older than the Merced, the type section of which is just across the bay from that of the San Pablo.

In 1903 Dr. W. H. Fairbanks ${ }^{27}$ deseribed, under the name San Pablo, a formation in San Luis Obispo County, which he correctly regarded as the equivalent of at least a part of the San Pablo of Merriam. The following year, however, he described these beds under the names Santa Margarita and Pismo formations, placing these in what he termed the San Pablo group.

In 1904, H. L. Haehl and Dr. Ralph Arnold ${ }^{28}$ subdivided the Merced series of Ashley in the Santa Cruz Mountains into the Purisima formation below (5000 ft.), and Merced formation above (5000 ft.). The upper limit of the Purisima was placed in that part of the section regarded by them as corresponding to the base of the type Merced at Seven Mile Beach.

From this time on there was considerable confusion as to whether or not the faunas of the Purisima and of the Merced in the Santa Cruz Mountains represented respectively the San Pablo and Merced as differentiated by Merriam.

In 1905, Mr. F. M. Anderson ${ }^{20}$ published a paper entitled "A Stratigraphic Study in the Mount Diablo Range of California." This was followed in 1908 by a paper entitled "Further Stratigraphic Study in the Mount Diablo Range of California." In these papers

26 Bull. Dept. Geol. Univ. Calif,, vol. 2, no. 4, pp. 109-118, 1898.

27 "The Stratigraphy of the California Coast Ranges," Journ. Geol., vol. 3, no. 4, p. 415, 1903.

28 "Miocene Diabase of the Santa Cruz Mountains in San Mateo County, California," Proc. Am. Phil. Soc., fol 43, pp. 15-53, 1904.

29 Proc. Calif. Acad. Sei., $3 d$ series Geol., rol. 2, no. 2, pp. 156-246, 1905. Proc. Calif. Acad. Sei., 4th series Geol., rol. 3, pp. 1-40, 1908. 
he divided the Upper Neocene on the east side of the Coast Ranges in the vicinity of Coalinga, in ascending order, into the Coalinga beds, and the Etchegoin formation, correlating the former with the Upper Miocene and the latter with the Pliocene. Later work in this field has shown that in the region to the northwest of Coalinga, a part of the area mapped by Anderson as Coalinga bets in reality belongs to his Temblor formation, Lower Neocene. To the west and southwest of Coalinga the beds mapped as Coalinga are in part equivalent to the beds mapped by Arnold and Anderson as Jacalitos, a formation to which reference will be made later. Anderson believed the Coalinga beds to be equivalent to the Santa Margarita of Fairbanks, but doubted their equivalence to the San Pablo. On pages 39 and 40 of the second paper cited above, he says:

In the former paper the San Pablo, as known from its type localities, was correlated with the Etchegoin; and this seems to be its closest ally among the stratigraphic series farther south, while in the Salinas Valley and elsewhere, beds that have been generally ealled San Pablo and otherwise correlated with it, are undoubtedly more elosely related to the Coalinga. The type locality of Ostrea titan, Tamiosoma gregarea, Pecten estrellanus, $P$. crassicardo and many other species deseribed by Conrad, was the Estrella Creek where Coalinga beds are abundantly fossiliferous. It yet remains to be shown that these beds are properly correlated with the San Pablo of the type localities; whereas, the fauna of the Coalinga beds are unmistakable in them, as in the Santa Margarita beds." "

In 1906, Arnold ${ }^{30}$ published a paper on "The Tertiary and Quarternary Pectens of California," in which he gives a brief review of the stratigraphy and palaeontology of the Tertiary formations of California. He recognizes the probable equivaleney of the San Pablo to the Santa Margarita of Fairbanks, but is undecided as to the relation of the San Pablo to the Purisima. On page 25 he states:

Much uncertainty exists in the mind of the writer as to the exact relation existing between the Purisima and San Pablo formations. After a careful examination of a large amount of material from the type locality of the two formations, and also from the supposedly equivalent formation in the Salinas Valley and adjacent regions, supplemented by field studies at most of the localities from which the material was obtained, it appears evident that the two formations are quite intimately related. It is a complex problem and is one which will require careful field and laboratory study for its solution. The Purisima fauna, taken as a whole, appears to be younger than the aggregate San Pablo fauna and for the sake of convenience will be considered as the later of the two.

30 U. S. G. S. Prof. Paper 47, 1906. 
One of the first papers published by the United States Geological Survey dealing with the distribution of the oil of California was by George Homans Eldridge, ${ }^{31}$ on the "Santa Clara Valley Oil District. Southern California." This appeared in 1907 and marks the beginning of a series of publications on the different oil fields of California, which have greatly stimulated the study of the Tertiary palaeontology of California. This paper was edited by Dr. Ralph Arnold after the death of Mr. Eldridge in 1905.

The section described is in the vicinity of Santa Clara Valley, Ventura and Los Angeles counties. A very thick series of Upper Neocene, designated the Fernando, is described as overlying the Lower Neocene (the Vaqueros and the Modelo). In speaking of this series Eldridge says :

The rocks that have received the name Fernando consist of an enormous succession of conglomerates, sandstones and arenaceous clays, largely of Pliocene age, developed over considerable portions of Southern California. Fossils collected at many localities and horizons throughout the formation indicate that it extends from the Upper Miocene (San Pablo formation of the general geologic column of the state) well up into the Pleistocene (San Pedro formation). It is possible to subdivide the formation locally on both lithologic and palaeontologic grounds, but taken over a considerable extent of territory these divisions merge into one another both stratigraphically and geographically by insensible gradations.

A fairly large fauna is listed from the Fernando on pages $24-28$ of this bulletin. The fauna is divided into three separate lists, representing the lower, middle and upper horizons. The author states that -the oldest fauna was found in the area north and northeast of Camulos, and is according to J. C. Merriam, the equivalent of the fauna of at least a part of the San Pablo formation. The middle fauna was found well developed in the region of Elsmere Cañon and Fernando Pass and probably represents the typieal fossiliferous portion of the Purisima and the lower part of the San Diego formation. The upper part of the Fernando extends well up into the Pleistocene, as is attested by the fossils found at Barlows' ranch and on the south slopes of Mount San Cayetano. The fauna listed from the lower Fernando is now known to belong to a higher horizon than the San Pablo, being as young as or younger than the Etchegoin or Purisima. Further reference will be made to this in the discussion of another paper. The list given on page 26 credited to J. G. Cooper obviously contains the names of a number of incorrectly identified species. For

31 U. S. G. S. Bull. No. 309, pp. 71-101, 1907. 
example, Astrodapsis whitneyi, a San Pablo species, and Chione whitneyi and (Chione) mathewsoni, Oligocene and possibly Lower Neocene species, are reported to be associated with Echinarachnius excentricus, a Recent Echinoid.

Dr. C. E. Weaver, ${ }^{32}$ at the time of the publication of his paper on the Stratigraphy and Palaeontology of the San Pablo, appears to have shared with Arnold the idea of the possible close relationship between the San Pablo and the Purisima. After reviewing Arnold's and Haehl's work on the Purisima, he concludes by saying that "at the present time it is impossible to say whether the two formations are equivalent or not."

In 1909 Arnold and Robert Anderson ${ }^{33}$ in a paper on the "Geology and Oil Resources of the Santa Maria Oil District, Santa Barbara County, California," gave a correlation table in which the San Pablo is represented as occupying a lower stratigraphic position than the Purisima. In this paper it is stated that certain beds in the Santa Maria Oil District which had been included in the Fernando were to be correlated with Fairbanks' Santa Margarita and Pismo formations. No species characteristic of the Santa Margarita, however, were listed by them.

In 1909 Arnold's" paper on the "Palaeontology of the Coalinga District" appeared. 'This was followed in 1910 by a final report on the "Geology and Oil Resources of Coalinga District" by Arnold and Robert Anderson. In these papers the marine Neocene, stratigraphically above what is known as the Vaqueros (Lower Miocene), is called Santa Margarita and is correlated with the type section of the Santa Iargarita of Salinas Valley. A new formation, the Jacalitos, is described and the Etchegoin formation, described by F. II. Anderson, is recognized.

Arnold recognized the distinctness of the fauna of the Santa Margarita as compared with that of the Jacalitos and of the Etchegoin, placing the former in the Middle Miocene and the latter two in the Upper Miocene; he considered the San Pablo of middle California to be equivalent to the upper Jacalitos and lower Etchegoin, and younger than the Santa Margarita. He states:

For a number of years the Santa Margarita formation was believed to be the equiralent of the San Pablo formation of the Mount Diablo region, but the stratigraphic work in the Coalinga district lias shown it to be older. It is

32 Univ. Calif. Publ. Bull. Dept. Geol., vol. 5, no. 16, pp. 243-269, 1909.

33 U. S. G. S. Bull. 322, 1909.

st U. S. G. S. Bull. 396, 1909; ibid., 398, 1910. 
quite evident that the Etchegoin formation represents at least a considerable part of the San Pablo, and as the Etchegoin lies well above the beds containing the Santa Margarita fossils it seems likely that the Santa Margarita formation is in part of greater age than the San Pablo. (Bull. 396, p. 22).

The new formation, described by Arnold ${ }^{35}$ as the Jacalitos, outcrops southwest of Coalinga in the vicinity of Jacalitos Creek, and includes, in part at least, beds mapped as Coalinga by F. MI. Anderson, to which reference has already been made. The Jacalitos, as described, consists of a series of soft, indurated sandstones, gravels and clays, about 3500 feet thick, resting upon a silicious shale lithologically similar to the typical Monterey shale found throughout the Coast Ranges. This shale was questionably referred to the Santa Margarita by Arnold because, at one locality, he states that he found in sandstones below the shale, fossils which he referred to Tamiosoma gregarea and Trophon carisaensis and which he believed to be characteristic of the Santa Margarita.

The fauna from the upper part of Arnold's Jacalitos is very similar to that of the Etchegoin and probably belongs to that series. But in the lower part of the formation is a fauna which, as a whole, is somewhat different from that of the Etchegoin.

Many geologists who have worked in the Coalinga field believe that the shale mapped by Arnold as Santa Margarita? is in reality Monterey shale. The writer will not enter into this controversy, except to state that it is still an open question. It is also thought by certain palaeontologists that Arnold's belief that the Jacalitos fauna is distinct from that of the Santa Margarita was a mistaken one, and that this fauna is merely a provincial phase of the Santa Margarita, heretofore unknown. Professor J. P. Smith ${ }^{36}$ evidently shared this belief when, in his paper on the "Geologic Range of Miocene Invertebrate Fossils," he divided the fauna of the upper Miocene into a lower Santa Margarita-San Pablo zone, and an upper Etchegoin zone, choosing not to recognize the Jacalitos. The writer will discuss the probable position of the Jacalitos fauna later.

In $1911 \mathrm{~J} . \mathrm{P}$. Smith ${ }^{37}$ published a paper containing a correlation table of the Neocene sections of California. He represented the Kirlier Pass section of the San Pablo as equivalent to the Santa Margarita of Salinas Valley, and the San Pablo Bay section as equivalent to the

35 Proc. Calif. Acad. Sci., 2 d series Geol., vol. II, no. 2, p. 174, 1905.

36 Proc. Calif. Acad. Sei., 4th series, vol. II, pp. 161-182. April 5, 1912.

37 "The Geologic Record of California," Journ. Geol., vol. 18, no. 3, pp. 216227,1911 . 
Etchegoin. In a subsequent paper ${ }^{38}$ he divided the Upper Miocene into two faunal zones, the lower or San Pablo-Santa Nargarita zone, and the upper, or Etchegoin zone.

In 1914 Mr. W. A. English ${ }^{39}$ published a paper on "The Fernando Group near Newhall, California," in which a list of 79 marine invertebrate species is given; these were obtained from the beds at the base of the Fernando, which had been regarded as equivalent to the San Pablo of middle California. The fauna listed by English is obviously much younger than that of the San Pablo and belongs rather to the Pliocene than to the Miocene. English's conclusions are as follows:

"The fauna listed by Arnold and Anderson from the Etchegoin of Coalinga contains eighty-four determined species, of which eighteen are common to the lower Fernando, ten of these being found in the Purisima also. Most of the species common to the Fernando and the Etchegoin have an extended vertical range, so that the relationship is not so definitely shown as between the Fernando and the Purisima. It is probable that the lower Fernando and the Etchegoin do not differ greatly in age."

\section{Position of Sin Pablo in the Neocene Section of California}

Relation to Etchegoin and other Formations correlated with the San Pablo.-The fauna of the San Pablo is distinctly older than that of the Etchegoin and certain other local California formations with which the latter has been correlated, including the Purisima, Merced, Fernando, Wildeat and the Pliocene deposits at San Diego and San Pedro. A comparison of the fauna of the Etchegoin, as listed by Arnold (Bull. 306, U. S. G. S., pp. 30-36), with that of the San Pablo shows some striking differences. The number of species common to the two is 38 , or $25+$ per cent, of the determinable species in the San Pablo; of these nearly all are either Recent or have a long range and are not generally recognized as good horizon determiners. For example, none of the Pecten species and none of the echinoderms of the San Pablo are found in the Etehegoin or in the other formations with which the latter is correlated. Again, the Etchegoin contains a larger percentage of Recent species. Arnold states the percentage of Recent forms in the Etchegoin to be 35. Later collecting in the Etchegoin has increased this percentage to over 40 . The percentage of

3s "Geologie Range of Miocene Invertebrate Fossils of California," Calif. Acal. Sei., 4th series, vol. III, p. 161, 191:.

3o Univ. Calif. Publ. Bull. Dept. Geol., vol. 8, no. 8, pp. 203-218, 1914. 
Recent mollusean species to the total determinable number of mollusean species in the San Pablo is $23+$, or about half that of the Etchegoin. A comparison of the percentage of Recent gastropods in the fauna of the Etchegoin with the percentage of Recent gastropods in the San Pablo also shows a striking difference. In the Etchegoin 25 per cent of the gastropods listed by Arnold are Recent. In the San Pablo the percentage of Recent is 11 . Only eleven species of the gastropods found in the San Pablo of Middle California are found in the Etchegoin.

Relation to Santa Margarita.-A survey of the fauna from the Santa Margarita of the type area and of the area north of Coalinga shows that it is much more closely related to the fauna of the San Pablo than to that of the Etchegoin. About one-half of the known species of the Santa Margarita are also found in the San Pablo of Middle California. The species which are common to the San Pablo and the Santa Margarita of the south are forms which are generally recognized as being good horizon determiners, such as the echinoderms, and the more highly ornamented pelecypods and gastropods.

The Santa Margarita north of Coalinga apparently represents only the Astrodapsis whitneyi zone of the San Pablo group of middle California. In the vieinity of Oilfields, the fossiliferous marine beds of the Santa Margarita are a little over 400 feet thick, and Astrodapsis whitneyi oceurs throughout the section. Here it is associated with species common to the Astrodapsis whitneyi zone of the San Pablo of Middle California, such as I'enus martini, Dosinia merriami. var. occidentalis, Dosinia arnoldi, Ostrea titan, Pinna alamedensis, Cancellaria pabloensis, and Trophon carisaensis. None of these have been found in either the Lower San Pablo, or in the Etchegoin.

The fauna from the Santa Margarita on the west side of the Coast Ranges is as yet imperfectly known. The Astrodapsis whitneyi zone is present and probably beds equivalent to the lower San Pablo of Middle California are also represented.

Relation to Jacalitos. - The fauna above the Astrodapsis whitneyi zone of the San Pablo of Middle California is not represented in the Santa Margarita section north of Coalinga. This upper fauna may possibly be in part equivalent to that of the Jacalitos of Arnold. This probable relationship is suggested by the presence in the Jacalitos of such species as Astrodapsis, ef. tumidus, large variety, Cyrena (Corbicula) californica, Mulinia, ef. pabloensis, Pecten, aff. crassicardo, 
Pecten estrellanus and Zirphaea, ef. dentata, all of which are found in the San Pablo but do not extend into the Etchegoin. On the other hand, the presence of many species in the Jacalitos which range into the Etchegoin but which have not been found in the Santa Margarita of the sonth or in the San Pablo of Middle Califormia would seem to suggest a later age than the upper San Pablo of Middle California and therefore a considerably later age than the Santa Margarita north of Coalinga. Some of the Etchegoin-Jacalitos forms which have not been found in the San Pablo or Santa Margarita are Echinarachnius gibbsi, Cardium, ef. meekianum, Macoma vanlecki, Mya japonica, Pecten oweni, Chrysodomus portalensis, Thais lamellosa, Thais etchegoinensis, Thais kettelmanensis and Turritella vanvlecki.

It is the writer's opinion that the Jacalitos beds are probably younger than the uppermost beds of the San Pablo of middle California and that future work will show that they have a closer relationship to the Etchegoin than to the San Pablo.

Relation to the Scutella breweriana beds.-It has been shown in the descriptions of the different sections that in some localities it is diffieult to draw a sharp line between the Monterey and the San Pablo groups. As has already been stated, the writer, in his description of the San Pablo of middle California, originally accepted the line between it and the underlying Monterey group as first defined by Professor J. C. Merriam, which line of division has been accepted by Professor A. C. Lawson in mapping beds of these horizons in this part of the state. (See folio U. S. G. S. No. 193.) At the present time, however, the writer is of the opinion that the Scutella breweriana beds, which have been considered as a part of the Monterey group by Merriam and Lawson, should be classed as either a part of the San Pablo group or as a distinct stratigraphic unit.

On the north side of Mount Diablo there is a good unconformity between the San Pablo and the Monterey group, but in this region the Scutella breweriana beds are not present.

Reference has already been made to an irregular contact on the sonth side of Mount Diablo which was regarded as the dividing line between the San Pablo and the Seutella breweriana beds. However, this contact is of such a character that it might be merely a local unconformity. In all the other sections studied by the writer no stratigraphic break between the Scutella breweriana beds and the San Pablo was apparent, and at some localities the division was made purely on the basis of the faunas; at other places, however, especially 
in the San Pablo Bay section, and eastward as far as the town of Walnut Creek, the change in fauna was accompanied by a change in lithology. The physical evidence seems therefore to show that, with local exeeptions, the San Pablo conformably overlies the Scutella breweriana zone. This is apparently corroborated by the close faunal relationship existing between the two, which was first pointed out by Professor Merriam. ${ }^{40}$ Weaver ${ }^{41}$ recognized this fact when he said: "The Upper Monterey faunal zone is very elosely allied to the San Pablo, and where the two lie in contact it becomes very difficult to draw the line of separation." Out of a known fauna of about sixty species from the Scutella breweriana zone, about 50 per cent are also found in the San Pablo. A number of species, however, appear to be characteristic of this zone and have not been found in the San Pablo. More collecting may show that the fauna from the Scutella breweriana zone is more distinct than it now appears. There is a much greater difference between the faunas of the Scutella breweriana zone, and of the Lower Monterey (Agasoma gravadum zone) as known at present, than exists between the fanna of the Scutella breweriana zone and that of the Lower San Pablo.

Stratigraphic as well as faunal evidence seems to bear out the conelusion that Seutella breweriana beds should be separated from the Monterey. The writer will reserve the discussion of the details of this evidence for a later paper.

\section{Age of the San Pablo}

Two of the most important methods which at least theoretically may be applied in the determination of the age of the San Pablo, with reference to the different horizons of the east coast and of Europe, are the "percentage method" and the identity of species. In applying the "percentage method" we have a means of correlation the principle of which is generally accepted, but as to the practical application there is considerable disagreement.

One of the first to use the percentage method in order to determine relation of the age of the Neocene horizons of the West Coast was W. H. Gabb. ${ }^{22}$ As has already been pointed out, he placed beds that are referred to in this paper as the San Pablo Group in the Pliocene. 1904.

40 Merriam, J. C., Univ. Calif. Publ. Bull., Dept. Geol., vol. 3, no. 16, p. 378,

41 Univ. Calif. Publ. Bull. Dept. Geol., vol. 5, no. 16, p. 267, 1909.

$42 \mathrm{Gabb}, \mathrm{W} . \mathrm{H}$., Palaeontology of California, vol. 1, p. 31. 
This was determined on the basis of the great number of Recent species in the fauna obtained from those beds. Using the same method he placed beds which, in part, correspond to the Monterey Group, in the Miocene.

C. E. Weaver, ${ }^{43}$ in his paper entitled "Stratigraphy and Palaeontology of the San Pablo Formation in Middle California," placed the San Pablo in the Pliocene, because of the great number of Recent species which the fauna contained.

Using in part this same method, Dr. Ralph Arnold in his paper on the Palaeontology of the Coalinga District, determined the Etchegoin, which is now known to be younger than the San Pablo, to be of Miocene Age. The following is quoted from page 46 of Arnold's ${ }^{44}$ paper:

According to the list given in this paper, the Etchegoin is represented by 84 recognizable species; of these, 55 species or varieties $(65 \%)$ are extinct, while 27 species $(35 \%)$ are still living in the Pacific Ocean. According to Lyell's classification this would place the formation decidedly in the Miocene.

It is now generally recognized by palaeontologists that the percentages used by Lyell in applying the "percentage method" must be modified to meet the modern refinement of species. Such a modification has already been attempted in the Neocene of Europe and in the Neocene of the east coast of North America.

W. H. Dall, ${ }^{45}$ in his paper "The Relation of the Miocene of Europe to that of other Regions and to the Recent Fauna," states that in the molluscan fauna of the Maryland Miocene only 10 per cent of the species survive. He says:

This small number is partly the result of the rather restricted limits adopted for species by the authors of this part of the volume as compared with the views prevalent in the time of Lyell. However, about $13 \%$ of the New Jersey species survive and $14 \%$ of the Floridan Chesapeake, so the estimate is not far from the normal for the Lower American Miocene. For the Upper Miocene of Duplin about 20\% are estimated to survive and $19 \%$ in the Suffolk district of Virginia. The intermediate Yorktown beds have about $17 \%$ of survivors.

In this paper Dall shows that the percentages of Recent species from the different horizons of the east coast Miocene agree fairly well with those of the corresponding horizons of the European Miocene and apparently the correlation of these different horizons of the Miocene

\footnotetext{
43 Univ. Calif. Publ. Bull., Dept. Geol., vol. 5, no. 16, pp. 268-209.

44 Bull. U. S. G. S., no. 396, 1909.

45 W. H. Dall, Maryland Geol. Survey. Miocene Text, pp. 49-50, 1904.
} 
and Pliocene of Europe and the east coast of North America has been, at least approximately, established on the basis of the percentage method.

The percentage of Recent molluscan species in the San Pablo of Middle California as listed by the writer is $23+$; as based upon the gastropods the percentage is only 11 per cent. If we use the percentages as applied to the east coast Neocene and if we can rely upon the equal refinement in the determination of the species, the San Pablo may be considered to be Upper Miocene in age, possibly Lower Pliocene.

Accepting this determination of the age of the San Pablo, the Etchegoin and other formations which are equivalent to it must of necessity be Pliocene in age. This determination is borne out by the high percentage of Recent species in the latter horizon.

As yet no satisfactory correlation has been made between the west coast and the east coast of North America or with Europe on the basis of identity of invertebrate species. The marine molluscan fauna of the east coast of North America, except for a few circumboreal species, is almost entirely different from that of the west coast. In general it may be said that for every coast of the different continents there is a distinct mollusean faunal province and on each coast there are distinct subfaunal provinces.

The great differentiation in molluscan faunas which we find at the present day apparently also existed during the Neocene. Very few species, if any, of the marine molluscan faunas of the Neocene of the west coast are found in the Neocene of the east coast or of Europe. The difficulty in correlating the Neocene of different parts of the west coast, as between Washington and California, also shows that local faunal provinces existed then as at the present time.

The same factors which have brought about the differentiation of the mollusean faunas of the Neocene and Recent over a large part of the world have produced the generalization of the land vertebrate faunas. The close connection of the great continental masses during the Neocene, separating seas which had previously been united, together with the well-marked climatic zones, isolated the invertebrate faunas of the different coasts and therefore brought about their differentiation. This allowed a wide migration of the vertebrate forms, the faunal provinces being enlarged so as to include more than one continent.

From the above facts it would seem self-evident that if determinable land vertebrates could be found in the west coast marine Neocene 
section, a correlation might be made with Europe which would be more accurate than anything that has as yet been made.

Recently some important discoveries of land vertebrates were made in the region of Oilfields, Fresno County, California, by a party sent out by the University of California. It is believed that these discoveries have a very significant bearing on the correlation of the Neocene of the west coast with the European type section of the Miocene and Pliocene.

Land vertebrates were found in the section referred to above at four different horizons. The most important collection was obtained from the upper beds of the Temblor ("Lower Neocene," called Vaqueros by Anderson and Arnold, Bulls. Geol. 306 and 308, U. S. G. S.). Here numerous well-preserved teeth of the genus Merychippus, a Miocene three-toed horse, were found with a number of other forms, such as mastodon, peceary, and camel. These land vertebrates were below strata containing a typical Temblor invertebrate fauna, the beds from which the fossils were obtained evidently being estuarine or delta deposits. For the details concerning the fauna of the Merychippus zone, the reader is referred to Professor J. C. Merriam' ${ }^{46}$ paper entitled "Correlation between the Tertiary of the Great Basin and that of the Marginal Marine Province in California." A full diseussion is given in this paper concerning the importance of this fauna as a means of determining the age of the Temblor beds. Professor Nerriam's final conclusion is that "the fauna of the Merychippus zone is near the stage of the Middle Miocene as represented by the Mascall and Virgin Valley faunas of the Great Basin region and by the Pawnee Creek stage of the Great Plains area."

In the north Coalinga section, to which reference has just been made, the Temblor beds are overlain unconformally by beds known as the Santa Margarita formation, which corresponds in part to the San Pablo Group of Middle California. The Santa Margarita of the Coalinga District does not inelude as much as the San Pablo Group of Middle California. The Lower San Pablo and the Scutella breweriana zone are apparently missing in the north Coalinga section. The writer has already expressed the opinion that the Scutella breweriana beds are younger than the typical Monterey, to which the Temblor belongs, and that the stratigraphic evidence shows that there is a considerable time break between the two stratigraphic zones. There is

:6 Science, n. S., vol. XV, no. 1035, pp. 643-615, August, 1914; also paper in press, Trans. Amer. Phil. Soc. 
good faunal evidence to show that both the Lower San Pablo and Scutella breweriana zone belong to a later horizon than the Temblor and Merychippus zone. During the time represented by the unconformity between the Temblor and Santa Margarita of this district, beds belonging to the Scutella breweriana zone and the Lower San Pablo were being deposited.

It will be very readily seen that the determination of the Upper Temblor as Middle Miocene has a very important bearing on the age of the San Pablo and of the Scutella breweriana zone. The lower limit of the latter can probably not be below upper Middle Miocene. The San Pablo being younger than the Scutella breweriana zone may possibly have its lower limit near the lower part of the Upper Hiocene. However, it must be admitted that this determination of the lower limit of the San Pablo is rather indefinite, first, because we are not certain of the relation of the Sentella breweriana beds to those of the Lower San Pablo; second, because at present it is impossible to estimate the length of time represented by the hiatus between the beds of the Temblor and the Scutella breweriana zone.

The best evidence that we now have as to the age of the uppermost beds of the San Pablo is also derived from land vertebrate fossils. The writer has already shown that the fauna of the Etchegoin is distinctly younger than that of the San Pablo. In the region of Oilfields, Fresno County, California, immediately to the north of Coalinga, the Santa Margarita, which here is equivalent to that of the Upper San Pablo of Middle California known as the Astrodapsis whitneyi zone, is overlain unconformably by about 1800 feet of beds which have been referred questionably by Arnold and Anderson ${ }^{47}$ to the Jacalitos Formation. No invertebrate species have been obtained from these beds and there is a question as to their exact correlation with the known marine horizons. This fact is to be noted, however, that these 1800 feet of strata lie unconformably above the Santa MIargarita and are below the type section of the Etchegoin, the latter of which was considered by Arnold to be Miocene in age. In the lower beds of the Jacalitos? vertebrate remains were found by the University of California party referred to above. Professor Merriam from this vertebrate evidence believes that the Lower Jacalitos? is near the age of the Rattlesnake or Thousand Creek beds which are referred to the early Pliocene.

The problem is complicated at this point by the fact that we do not have marine invertebrates associated with the vertebrates found

47 Bull. U. S. G. S., 398, p. 107, 1910. 
in the Lower Jacalitos(?). If these beds, which appear to be land or estuarine in origin, prove to be of the same age as those of the typical Jacalitos on Jacalitos Creek to the southwest of Coalinga, then possibly we may be able to determine the upper limit of the San Pablo quite accurately.

Another horizon from which land vertebrates were obtained was in the type section of the Etchegoin. Horse teeth of the genus Protohippus, together with a number of other forms, were secured in the basal beds of the Etchegoin. This fauna together with the vertebrate evidence of the basal beds of Jacalitos?, stratigraphically 1800 feet lower, shows quite conclusively that the Etchegoin is distinetly Pliocene rather than Miocene.

Probably the best evidence showing the age of the uppermost beds of the San Pablo of Middle California comes from vertebrate material obtained in the fresh-water beds which in Middle California overlie unconformably the San Pablo Group. This material was described by Professor J. C. Merriam" ${ }^{48}$ in his paper "Vertebrate Fauna of the Orindan and the Siestan Beds in Niddle California." His conclusions as to the age of these beds as shown by the vertebrates was as follows:

The mammalian remains known from both the Orindan and Siestan up to the present time all represent forms such as might be expected in the late Miocene or in the earliest Pliocene, but it will be necessary both to have better material from the Orindan and Siestan and to have well-known faunas of western Miocene and Pliocene for comparison before the last word on the age retermination can be pronounced.

Considering the indefiniteness of all the factors concerned, one would not seem justified in being more definite than to state that the Orindan and Siestan faunas are near a late Miocene stage. When the fam of the two formations are better known, it may appear that more than one stage is represented.

\section{CONCLUSIONS}

(1) The San Pablo division should be designated a group rather than a formation, as these terms are used by the United States Geological Survey.

(2) The Neocene of California is divisible into at least three distinct stratigraphic groups, which in this paper are called Lower, Middle, and Upper Neocene; the San Pablo group represents the Middle Neocene; the Lower Neocene is represented by the Monterey group, including the Vaqueros, Temblor, and Monterey shale; the Upper

48 Univ, Calif. Publ. Bull, Dept. Geol., vol. 7, no. 19, pp. 381-385, 1913. 
Neocene by the Etchegoin, Merced, Purisima, Wildeat, and Fernando groups, and by the San Pedro and San Diego Pliocene.

(3) The fauna of the San Pablo group of Middle California is divisible into two major zones. These are quite distinct as shown by the mollusks and the echinoderms. Each of the zones is again divisible into minor faunal zones which are based largely upon the restricted range of echinoderm species, but in part upon the similarly restricted range of some of the mollusks.

(4) The San Pablo deposits are for the most part of true marine origin. In certain sections, however, beds are found at different levels, which appear to have been deposited under estuarine, brackish-water, or questionably fresh-water or land conditions; these appear to represent local uplifts about the border of the basin of deposition.

(5) The temperature of the San Pablo sea was about the same as that of the waters now found along the coast of Middle California between Point Conception and Santa Barbara.

(6) A large percentage of the extinct species in the San Pablo are closely allied to species living on the California coast at the present time; the latter forms being descended from the earlier species.

(7) The age of the San Pablo group is believed to be Upper Miocene; this is determined first, by the low percentage of Recent species in the group; and, second, by evidence afforded by the vertebrate material found above and below the group.

(8) The San Pablo beds of Middle California are correlated with the Santa Margarita formation in San Luis Obispo County as described by Fairbanks, and with the beds mapped as Santa Margarita in the Coalinga oil field and in the southwest end of the San Joaquin Valley.

(9) The San Pablo group is distinctly older than the Etehegom, Purisima, Merced, Fernando, and Wildeat formations, and older than the San Pedro and San Diego Pliocene. 


\section{BIBLIOGRAPHY}

ANDerson, F. MI.

A Stratigraphic Study in the Mount Diablo Range of California. Proc. Calif. Acad. Sci., $3 d$ series, Geol., vol. 2, no. 2, pp. 156-246, 1905.

A Further Stratigraphic Study in the Mount Diablo Range of California. Proc. Calif. Acad. Sci., 4th series, Geol., vol. 3, pp. 1-4, 1908.

ARNOLD, RALPH,

Tertiary and Quaternary Pectens of California. U. S. G. S. Prof. Paper, $47,1906$.

Palaeontology of the Coalinga District. U. S. G. S. Bull., 396, 1909.

ArNold, Ralph, and ANDERSON, Robt.

Geology and Oil Resources of the Santa Maria Oil District, Santa Barbara County, California. U. S. G. S. Bull., 322, 1909.

Geology and Oil Resourees of the Coalinga District. U. S. G. S. Bull. 398, 1910.

Arnotd, Ralph, Braniner, J. C., and Newsom, J. J.

Santa Cruz Folio, No. 163, 170.

Ashley, G. H.

The Neocene Stratigraphy of the Santa Cruz Mountains in California. Proc. Calif. Acad. Sci., 2nd series, vol. 5, pp. 273-367, 1895.

CLARK, B. L.

The Neocene Section at Kirker Pass on the North Side of Mount Diablo. Univ. Calif. Publ. Bull. Dept. Geol., vol. 7, no. 1, pp. 47-60, 1912.

CONRAD, T. A.

Report on the Palaeontology of the Survey. Pac. R. R. Reports, vol, 7, pp. 189-196, pls. 1-10, 1859; Appendix to report of Thomas Antisell.

Descriptions of New Marine Shells from Upper California Collected by Thomas Nuttall. Journ. Acad. Nat. Sei., Philadelphia, vol. 7, pp. 227268 , pls. $17-20,1834$.

Description of three new Genera, twenty-three new Speeies of Mfiddle Tertiary Fossils from California, and one from Texas. Proc. Acad. Nat. Sci. Phil., vol. 8, pp. 312-316, 185 ،

Deseription of Tertiary Fossils Collected on the Survey. Pac. R. R. Reports, vol. 6, part A, no. 2, pp. 66-73, pls. 2-5, 1857; Appendix to report of Dr. J. S. Newberry.

COOPER, J. G.

Catalogue of California Fossils. 7th Ann. Rept. Calif. State Min. Bur., pp. $221-308,1880$.

DALL, W. H.

The Relation of the Miocene of Europe to that of other Regions and to the Recent Fauna. Maryland Geol. Surv. Miocene, Text, 1904.

Miocene of Astoria and Coos Bay, U. S. G. S. Prof. Paper, 59, pl. 14, figs. 1-11, 1909.

Wagner Free Institute of Science., vol, 3, pt. 3, 45 and 46, 1895-1903.

Eidididge, George Homans.

Santa Clara Valley Oil District, Southern California. U. S. G. S. Bull. 309, 1907 .

Englisit, W. A,

The Fernando Group near Newhall, California. Univ. Calif. Publ. Bull., Dept. Geol., vol. 8, no. 8, pp. 203-218, 1914. 
Fatrbanks, TV. H.

The Stratigraphy of the California Coast Ranges. Journ. Geol., vol. 3, no. 4, p. 415, 1903. San Lu1s Folio No. 101, U. S. G. S. Publ., 1904.

GABB, W. MI.

Geological Survey of California, Palaeontology, vol, 2, pp. 1-299, pls. 1-36, 1869.

HAEHL, H. L., and ARNold, RALPH.

Miocene Diabase of the Santa Cruz Mountains in San Mateo County, California. Proc. Amer. Phil. Soc., vol, 43, pp. 15-53, 1904.

JONES, W. F.

Geology of the Sargent Oil Field. Univ. Calif. Publ. Bull., Dept. Geol., vol. 6, no. 3, pp. 55-78, 1911.

Lathson, A. C., and PALACHE, C.

The Berkeley Hills, a Detail of Coast Range Geology. Univ. Calif. Publ. Bull. Dept. Geol., vol. 2, no. 12, pp. 349-450, 1902.

Merrian, J. C.

The Distribution of the Neocene Sea-Urchins of Middle California. Univ. Calif. Publ. Bull. Dept. Geol., vol. 2, no. 4, pp. 109-118, 1898.

The Tertiary Sea-Urehins of Middle California. Proc. Calif. Acad. Sci., 3d series Geol., vol. 1, pp. 161-175, 1899.

NEWBERRY, J. S.

Pac. R. R. Rept., vol, 6, pp. 13-14.

REMOND, Atgust.

Description of Two New Species of Bivalve Shells from the Tertiaries of Contra Costa County. Proc. Calif. Acad. Nat. Sci., vol. 3, pp. 13-14, Mareh, 1863.

Deseription of Four New Species of Echinodermata from the Tertiaries of Contra Costa County. Proc. Calif. Acad. Sci., vol. 3, pp. 52-54, August, 1863.

ShUMard, B. F.

Descriptions of New Fossils from the Tertiary formation of Oregon and Washington territories and the Cretaceous of Vancouver Island. Collected by wr. John Evans, U. S. Geologist, under instructions from the Department of the Interior. Transactions U. S. G. S. No. 59, p. 126, 1858.

SMITH, J. P.

The Geologic Record of California. Journ. Geol., vol. 18, no. 3, pp. 216$227,1911$.

Geologic Range of Miocene Invertebrate Fossils of California. Proc. Calif. Acad. Sci., 4th series Geol,, vol. 3, pp. 161-182, 1912.

TURNER, H. W.

Geology of Mount Diablo, California. Bull. Geol. Soc. Amer., vol. 2, pp. $383,414,1891$.

The Rocks of the Mount Diablo Range of California. Journ. Geol., vol. 6, pp. $493-499,1898$.

WeAver, C. E.

Stratigraphy and Palaeontology of the San Pablo Formation in Middle California. Univ. Calif. Publ. Bull. Dept. Geol., vol. 5, no. 16, pp. 243-269, 1909.

A Preliminary Report on the Tertiary Palaeontology of Western Washington. Wash. Geol. Surv, Bull., no. 15, pp. 1-80, pls. 1-15, 1912.

WhitNex, J. D.

Geological Survey of California, vol. 1, p. 31, 1865. 


\title{
DESCRIPTION OF SPECIES
}

\author{
Pelecypoda \\ YOLDIA CARNAROSENSIS, n.sp. \\ Plate 48 , figure 6
}

Shell medium in size, beaks low and inconspicuous, situated about two-thirds the distance from the anterior to the posterior end. Anterior dorsal edge long and very gently convex; posterior dorsal edge gently concave. Posterior extremity subtruncate to bluntly rounded, the blunt subtruncate end being subangulate at the junction with the posterior dorsal edge and indistinetly separated from the ventral edge. Surface sculptured by somewhat irregular ineremental lines or concentric ribs. On the surface near the posterior end there is a distinct sulcus which reaches from the beak to a little below the angulation on the posterior end. Hinge plate unknown.

$\boldsymbol{Y}$. carnarosensis, n. sp., somewhat resembles $Y$. cooperi Gabb, a recent West Coast species. It differs in the following respects: the posterior end is not so attenuated, the concentric ribbing is not so regular, the distinct sulcus on the posterior extremity is lacking on Y. cooperi.

Dimensions.-Length about $40 \mathrm{~mm}$; height $20 \mathrm{~mm}$.

Occurrence.-From San Pablo Group, Carnaros Creek, Napa County.

\section{PINNA ALAMEDENSIS Yates}

Plate 48 , figure 3

Pinna alamedensis Yates. Rept. State Mineral, of Calif., 1887, p. 259.

Pinna alamedensis Yates. Calif. State Mining Bureau, Bull, no. 4, 1894, p. 56, pl. IV, fig. 53.

This species has nine concentric inequidistant rounded wrinkles emanating from the open side, and turning toward the hinge at nearly right angles, the entire shell marked by longitudinal narrow ribs (about forty), which, radiating from apex, extend to the basal margin, becoming more indistinct as they approach the lower margin. These ribs, at their intersection with the lines of growth, are ornamented by slight elevations, forming zigzag markings along the lines of growth. The hinge side is straight the entire length, the opposite side running parallel for about one-half the distance from base to apex, where it makes a sharp curve, thence at an angle of about forty-five degrees to the apex. Length 9, width 5, and thickness about 2 inches. Locality, Alameda Creek, Alameda County. Only one specimen found, and that a very fine one, in the center of a round sandstone bowlder. Miocene. 
$P$. alamedensis Yates is a very common species in the Upper San Pablo Group, of which it appears to be characteristic. It is noticeable for its large size and the thickness of the prismatic outer layer. Some of the specimens collected have a maximum antero-posterior length of ten inches, with a maximum width at right angles to that of about five and one-half inches.

\section{OSTREA BOURGEOISII Rémond Plate 43}

Ostrea bourgeoisii Rémond. Proc. Calif. Acad. Sci., rol. 3, p. 13, 1863.

Ostrea bourgeoisii Rémond. Palaeontology of California, vol. 2, p. 36, pl. 11, fig. 57, 57a, 1863.

The description is from two lower valves, from the collections of Mr. l'Abbé Bourgeois (Pont-Levoy, Franee), and Mr. Pioche (San Francisco).

Shell sub-oval, higher than long, strongly contracted near the cardinal area, sub-rounded on the ventral margin; inferior valve comparatively thin, convex, irregular exteriorly, with remote, somewhat rugose, plaits of growth. Ligament fosset long, profound, minutely wrinkled and finely striated, oblique and turned downwards; muscular impression very large, oblique, and sub-central, somewhat prominent.

Locality: vicinity of Kirker's Pass, from a late Tertiary bed.

0 . bourgeoisii Rémond has been confused in the past with $O$. titan Conrad. The writer in a previous paper (Univ. Calif. Publ. Bull. Dept. Geol., vol. 7, no. 4, p. 54, 1912) listed it as O. titan Conrad. Other writers previous to this made the same mistake. Gabb reports o. titan Conrad from Kirker Pass. All the speeimens that the writer has seen from that locality, including specimens of the old State Survey in the collections of the University of California and labeled 0 . titan Conrad, belong to the species $O$. bourgcoisii Rémond. So far the writer has not seen a specimen of $O$. titan Conrad from the Lower San Pablo group or the upper part of the Ionterey group. In the Lower Monterey there is an oyster that is very close to, if not identical with, 0 . titan Conrad as seen in the Santa Margarita beds of San Luis Obispo County.

O. bourgeoisii Rémond somewhat resembles 0 . titan Conrad in its size and thickness, though it is never as large. The maximum length as measured from the beak through the muscle impression is about eight to ten inches, with a maximum width at right angles to this of about five inches. Both valves vary considerably in thickness; sometimes the shell of the ventral valve has a thickness of from two to three inches. The ventral valve is usually only slightly more convex than 
the upper valve but is usually somewhat thicker. The fine radiating ridges on the surface, described by Rémond, are not constant, appearing on only a few specimens that the writer has seen.

$O$. bourgeoisii Rémond differs from $O$. titan Conrad in that the ligamental pit is narrower and the ligamental callus is heavier; on Ostrea titan Conrad the ligamental pit extends nearly across the anterior end of the shell; the muscle impression on $O$. bourgeoisii Rémond is much smaller and is nearer the posterior end of the shell than on o. titan Conrad; on the latter species the muscle impression is sometimes nearly half the widtli of the shell; the ventral valve of 0 . titan Conrad is usually more strongly convex. A large number of specimens of both species were examined and these differences were found to be constant.

Occurrence.-Very common in the Lower San Pablo group at Kirker Pass, University of California loeality 2140; also from the south side of Mount Diablo in the Lower San Pablo Group and Upper MIonterey Group.

\section{PECTEN (PLAGIOCTENIUM) BLINEATUS, n. sp.}

Plate 64 , figures 3 and 4

Shell thin, medium in size, equivalved and equilateral, usually longer than high. Dorsal edges gently concave, the anterior dorsal edge usually being shorter than the posterior; ventral edge quite strongly and regularly areuate. Apieal angle averaging about $102^{\circ}$. Hinge plate about half as long as the length of the shell. Both valves gently convex and similarly sculptured by 18 to 20 low, flat-topped, radiating ribs with interspaces little wider than the tops of the ribs. In each interspace and almost filling it there is a low, broad, flattopped interrib. On some specimens these broad interribs become almost as prominent as the ribs themselves; this is more especially noticeable near the dorsal edges, where the ribbing becomes finer. Anterior ear of right valve notched, bearing three to four fine, radiating riblets; posterior edge of posterior ear slightly oblique, bearing very faint, almost obsolete, radiating riblets. Ears of left valve similar to those of the right valve, except that the anterior ear is not notched.

$P$. bilineatus, $\mathrm{n} . \mathrm{sp}$., has been confused with $P$. raymondi, $\mathrm{n} . \mathrm{sp}$., and $P$. pabloensis Conrad, which species also oceur in the same locality. Arnold's description of $P$. pabloensis Conrad (U. S. G. S. Prof. Paper, No. 47, pp. 87-89) in part applies very well to $P$. bilineatus rather than to what is taken by the writer as being the true $P$. pabloensis Con- 
rad. Arnold figured $P$. pabloensis as three distinct species, which are seen on Plate XXVII of the publication mentioned above. Figure 5 represents a very good specimen of the left valve of $P$. pabloensis Conrad. Figure 6 represents a good specimen of a right valve of $P$. bilineatus, n. sp., while Fig. 7 appears to represent a left valve of $P$. raymondi, n. sp.

$P$. bilineatus, n. sp., differs from $P$. pabloensis Conrad in that the ribs are wider and not so far apart, they do not show the tendency to split as in the other species, the interrib is much broader. The concentric sculpturing is different, on $P$. pabloensis Conrad it is distinctly imbricated, the species belonging to the same subgenus as Pecten hastatus Sowerby-that is, Chlamys; on $P$. bilineatus it is not imbricated.

$P$. bilineatus resembles $P$. raymondi, n. sp., in the number and width of the ribs, in the width of the interspaces, and in general outline; it differs from that species in the following respects: it has a thinner shell, the ribs are not so prominent; on $P$. raymondi there is no interrib; the two valves of the latter are unequal, the right valve being flat and the left valve convex, thus belonging to the subgenus Pecten; the valves of $P$. bitineatus are both convex, the species belonging to the subgenus Plagioctenium.

Dimensions.-Of type (pl. 64, fig. 3), a right valve, length $45 \mathrm{~mm}$; height $38 \mathrm{~mm}$.

Occurrence.-This species occurs in the famous Pecten beds on San Pablo Bay near the town of Rodeo, University of California locality 1632.

\section{PECTEN (PECTEN) CIERBOENSIS, n. sp.}

Plate 47 , figure 6

Shell rather small; apical angle about $90^{\circ}$; dorsal edges slightly concave; ventral edge very strongly arcuate. Surface sculptured by fifteen fairly coarse, flat-topped ribs with flat-bottomed interspaces about as wide as the tops of the ribs, interspaces and ribs narrowing rapidly toward the beak, incremental lines inconspicuous. Anterior ear with four fairly heavy radiating ribs; bysal notch deep; anterior edge broken; posterior ear broken.

The writer has only one specimen of the right valve of this species, but it appears to be so distinct as to be worthy of a specific name and description.

Dimensions.-Length, $22 \mathrm{~mm}$; height, $24 \mathrm{~mm}$.

Occurrence.-In the basal beds of the San Pablo Group of the type section. 


\section{PECTEN (PLAGIOCTENIUM ?) CRASSIRADIATUS, n. sp.}

Plate 47 , figure 7

Shell medium in size; fairly heavy; apical angle about $98^{\circ}$; height about equal to the length; dorsal edges nearly straight. Hinge plate over half the length of the shell. Right valve sculptured by sixteen heavy, broadly rounded, radiating ribs, which become somewhat narrower near the margins; interspaces very narrow and deep. Dorsal margins rather strongly depressed, the depressed area being narrow and without ribs. Anterior ear longer than posterior, deeply notched with anterior edge gently convex, sculptured by four fairly heary radiating ribs. Left valve unknown.

This species appears to be quite unique. The writer has seen only one specimen of the right valve.

Dimensions.-Height $47 \mathrm{~mm}$; length apparently about the same as height.

Occurrence.-In the lower San Pablo, associated with Astrodapsis tumidus, subsp. cierboensis, Scutella pabloensis, Chrysodomus pablocnsis, ete., University of California locality 367.

\section{PECTEN (PECTEN) RAYMONDI, n. sp.}

Plate 46 , figures 1 and 2 ; plate 47 , figures 1 and 2

Shell rather heavy, subcircular, nearly equilateral, inequivalved; hinge line averaging slightly more than one half the length of the shell; height about equal to length. Anterior ears slightly longer than posterior ears. Apical angle about $102^{\circ}$. Dorsal edges slightly concave; posterior edge longer than anterior edge. Left valve ventricose, sculptured by seventeen to twenty squarish to slightly rounding, heavy, radiating ribs, the interspaces averaging about the same width as the ribs; on some specimens the ribbing tends to become a little finer toward the dorsal edges than on the middle of the disk. Surface also covered by medium fine to coarse concentric lines of growth. Anterior ear sculptured by three to five medium fine radiating ribs; anterior margin of ear slightly notehed. Posterior ear with four to five radiating ribs, posterior edge straight, and sloping forwards. Right valve flat, sculptured by seventeen to twenty radiating flattopped ribs which are usually not as prominent as the ribs of the left valve. On some of the smaller specimens the right valve is slightly ventricose but never so much as the left valve. Interspaces between 
radiating ribs about equal in width to that of ribs. Concentric lines of growth usually not so heavy as on left valve. Anterior ear deeply notched, sculptured by three to five medium fine radiating ribs.

This species has been confused with $P$. discus Conrad. Arnold in his paper "The Tertiary and Quaternary Pectens of California" (Prof. Paper U. S. G. S., no. 47) plate XXVII, fig. 1, figures under the name of $P$. discus a very good specimen of $P$. raymondi, n. sp. This came from the San Pablo near the town of Walnut Creek. Figure 2 on the same plate, also listed as $P$. discus Conrad, shows a rather broken specimen of a species which is common in the Monterey shale in the southern part of the state. This form is referred to by Dall (Trans. Wagner Free Inst. Sci., vol. 3, pts. 3-4, pp. 704, 705) as $P$. discus Conrad. The writer has some very good specimens of this last form from the Monterey shale. It is very different from $P$. raymondi, being equivalved, thinner and shows a distinct fine imbrieated concentric sculpturing. It is somewhat similar to $P$. pabloensis Conrad in that sometimes a narrow riblet is seen in the interspace of the radiating ribs and there is a tendency for the major radiating ribs to divide dichotomously, also they become finer towards the dorsal margins of the shell.

Neither $P$. raymondi, n. sp., nor the Monterey species referred to above, agrees with the original description or picture of $P$. discus Conrad. The type of $P$. discus Conrad evidently eame from the Lower Miocene, Vaqueros or Monterey. Conrad's meagre deseription and his picture agree fairly well with $P$. andersoni Arnold, a characteristic Mionterey or Temblor form. It therefore seems very probable that $P$. andersoni Arnold should be considered as a synonym of $P$. discus Conrad. Before the change is made, however, good material should be obtained from the section from which the type of $P$. discus Conrad was obtained. Therefore the writer for the present accepts Dall's determination of $P$. discus, leaving for the present $P$. andersoni as a legitimate species.

$P$. raymondi, n. sp., may easily be, and has many times been, mistaken for $P$. andersoni Arnold. Both species belong to the subgenus Pecten, having the left valve convex and the right valve flat. $P$. raymondi, n.sp., differs from $P$. andersoni Arnold in the following respects: It has a larger number of radiating ribs; the interspaces are not so wide. On $P$. andersoni Arnold the radiating ribs of the left valve are much narrower at the top than at the bottom, the top of the rib tending to be subangulate. On $P$. raymondi, n. sp., the radiating 
ribs of the left valve are broadly rounded to flat-topped. The radiating ribs of the flat right valve of $P$. andersoni Arnold are distinetly rounded, but not as narrow-topped as those of the left valve. The radiating ribs of the right valve of $P$. raymondi are broad and usually flat-topped. $P$. andersoni Arnold appears to be characteristic of the Monterey or Temblor Horizon. The writer has never seen it in the Upper Miocene.

$P$. raymondi, n. sp., is a common and a very characteristic species of the Upper Miocene. It is very common in the San Pablo of Middle California and also in the Seutella breweriana zone. It is also very common in the "Santa Margarita" in the southern part of the state.

Named in honor of Professor W. J. Raymond of the University of California.

Dimensions.-Large speeimen figured, height, $50 \mathrm{~mm}$; length, $50 \mathrm{~mm}$. ; diameter, $7 \mathrm{~mm}$.

Occurrence,-University of California localities 1942, 1947, 1946, 1478, 136, ete; also from the Scutella breweriana zone in Middle California and from the Santa Margarita of the southern part of the state.

\section{PECTEN (CHLAMYS) PABLOENSIS Conrad}

Plate 47, figure 8; plate 48, figure 2

1857 Pecten pabloensis Conrad, Pae. R. R. Rept., vol. 6, pt. 2, 1857, pp. 71, pl. 3, fig. 14 .

$18 s 8$ Pecten pabloensis Conrad.? Cooper, 7th Ann. Rept. Calif. State Mineral., 1888, p. 259.

1899 Pecten (? Plagioctinium) pabloensis Dall. Trans. Wagner Free Inst. Sei., vol. 3, pt. 4, 1898, p. 703.

1906 Pecten pabloensis Conrad. Arnold, Prof. Paper U. S. G. S. no. 47, p. S8, pl. XXVII, figs. 6, 6a (not fig. 5 and 5 a or 7 ).

1909 Pecten pabloensis Conrad. Weaver, Univ. Calif. Publ. Bull., Dept. Geol., vol. 5, no. 6, P. 262.

1912 Pecten pabloensis Conrad. Smith, Proe. Calif. Acad. Sci., 4th series, vol. III.

Shell thin, medium in size, nearly equilateral, inequivalved; height about equal to width; apical angle averaging about $90^{\circ}$; hinge line about half the length of the shell; dorsal edges gently concave; posterior dorsal edge longer than anterior dorsal edge; anterior ears slightly longer than posterior ears. Right valve sculptured by seven. teen to nineteen low, rounding ribs with interspaces averaging a little wider than the top ribs; a fine narrow riblet in each interspace. Surface also sculptured by fine, imbricated, concentric lines which, when 
the valves have not been too much eroded, tend to come to a point on the tops of the ribs and riblets. The larger ribbing becomes finer toward the dorsal margins while the riblets become more prominent, the last few ribs not being distinguishable from the riblets; sometimes there are six or seven or even more of these finer undifferentiated ribs near the margins. The ribbing on the larger specimens is broader and flatter and tends to be dichotomous toward the ventral edges; this splitting of the ribs first makes its appearance toward the outer edges, but on the larger shells all the ribs may be dichotomized ventrally; in some cases the riblets also are dichotomous. Anterior ear deeply notched, sculptured by four to six fairly prominent radiating ribs. Margin of posterior ear straight, seulptured by three to six medium fine, radiating ribs. Left valve usually more ventricose than right valve; sculptured by seventeen to nineteen low, rounded radiating ribs with the interspaces nearly twice as wide as the tops of the ribs; a fine narrow riblet in each interspace as on right valve; ribbing finer toward dorsal margins, becoming indistinguishable from riblets; the larger ribs as in the case of the right valve tend to become dichotomous and the riblets also tend to split. Surface imbricated as on right valve. Anterior ear slightly notched, seulptured by four to six medium fine radiating ribs; posterior ear with about equal number of ribs, posterior edge straight. Ligamental groove fairly heavy. Resilifer small. Adductor musele impression large.

$P$. pabloensis is found associated with $P$. bilineatus, $P$. holwayi and $P$. crassicardo. It has been confused many times with $P$. bilineatus and $P$. raymondi. In Professional Paper 47, pl. XXVII, fig. 5, Arnold has figured the left valve of this species. Figure 6 of the same plate represents a specimen of $P$. bilineatus, while figure 7 appears to represent the left valve of $P$. raymondi, n. sp.

Dimensions.--Specimen figured on plate 47 , figure 8. Height, 32 $\mathrm{mm}$; length, $39 \mathrm{~mm}$; length of hinge, $22 \mathrm{~mm}$; length of anterior dorsal edge, about $18 \mathrm{~mm}$; length of posterior dorsal edge about 22 $\mathrm{mm}$. ; diameter of right valve, about $3 \mathrm{~mm}$.

Occurrence.-On San Pablo Bay in the Upper San Pablo group, University of California localities 1632, 1613, 1614 and 1615; also, on the north side of Mount Diablo in the Upper San Pablo, University of California locality 1891. 
PECTEN (PALLIUAI) HOLWAYI, n. sp.

Plate 47 , figure 5

Shell large, equilateral; posterior, anterior, and ventral margins strongly depressed; surface of shell with a marked step-like depression, indicating a former depressed ventral margin, situated not quite one third the distance from the ventral edge to the beak. Surface sculptured by three heavy rounding ribs; these ribs are very prominent between the step-like depression and the ventral depressed margin, but very faint and almost disappearing between the step and the beak. Surface also sculptured by fine, regular, radial striae or riblets, which cover both the interspaces and the ribs, and by fine imbricate concentric lines. Shell feebly lirate internally, the lirations being most prominent on the depressed area along the ventral edge. Adductor muscle sear prominent.

Named in honor of Professor R. S. Holway, Associate Professor of Physical Geography at the University of California.

Dimensions.-Height of shell, $85 \mathrm{~mm}$; length of shell, $90 \mathrm{~mm}$.; greatest diameter of valve, about $24 \mathrm{~mm}$.

Occurrence.-In Pecten beds of the Upper San Pablo group on San Pablo Bay to the south of the town of Rodeo, University of California locality 1632.

\section{PECTEN (PATINOPECTEN) WEAVERI, n. sp.}

Plate 45, figures 1 and 2

Shell discoidal, broader than high, equilateral, nearly equivalved; apical angle about $90^{\circ}$; dorsal edges gently concave; hinge line about half the length of the shell. Right valve sculptured by about fourteen low, broad-topped, squarish ribs, the interspaces between which are flat-bottomed and about as wide as the tops of the ribs. Surface concentrically sculptured by rather coarse, somewhat irregular incremental lines. Anterior ear slightly longer than posterior, deeply notched, sculptured by three medium coarse, radiating ribs. Posterior ear marked by two or three faint radiating riblets. Left valve sculptured by fourteen fairly prominent, rounded, radiating ribs with interspaces about equal to the width of the ribs; the ribs next to the dorsal edges are not so prominent as the others. Surface also eovered by fine, sharp, incremental lines. Anterior and posterior ears each marked by three medium fine, radiating riblets; anterior edge of anterior ear slightly notched. 
The differences in the sculpturing on the two valves is quite noticeable; the left valve, with fairly prominent rounded ribs and the sharp incremental lines, contrasts quite strongly with the right valve, with its low, squarish ribs and coarser incremental lines.

Named in honor of Professor Charles E. Weaver of the University of Washington.

Dimensions.-Of left valve, plate 45 , figure 2. Height, $34 \mathrm{~mm}$; length, $36 \mathrm{~mm}$.

Occurrence.-From the basal beds of the San Pablo group on San Pablo Bay, University of California localities 1141 and 401.

\section{MYTILUS MERRIAMI, n. sp.}

Plate 48 , figures 7 and 8

Shell thick, very ventricose. Beaks heavy, bluntly pointed. Hinge plate below the beaks very heavy. Base sometimes straight, sometimes gently concave. Posterior edge angulated, the point of angulation being situated anterior to the middle. Posterior extremity evenly rounded. Surface of shell covered by irregular coarse incremental undulations. Highest point of convexity of surface anterior to the middle of the valve; anterior slope high and nearly perpendicular; posterior slope steep, dropping at an angle of nearly $30^{\circ}$ as measured at the point of angulation on the posterior edge; to the rear of this point the shell is not so convex; no teeth on thickened hinge plate. Thickened area below the beaks obscurely grooved; deep elongate anterior adductor muscle scar just below the thickened hinge plate.

II. merriami, n. sp., differs from $\boldsymbol{H}$. coalingensis Arnold and the variety of that species from the San Pablo, in that the slopes are more ventricose; the posterior slope is steeper; the valves do not flatten out toward the base so markedly; it lacks the deep pit which lies immediately below the cardinal hinge plate on the other two forms.

$M$. merriami, n. sp., differs from $M$. perrini, n. sp., also from the Upper San Pablo Group, in being larger, in having a heavier hinge plate; the valves are higher and more convex and the anterior and dorsal slopes are much steeper.

II. merriami, n. sp., differs from $M$. mathewsonii Gabb, a Lower Miocene form, as follows: On $\boldsymbol{M}$. merriami, $\mathrm{n}$. sp., the base is straight, on $M$. mathewsonii Gabb it is eurved, on the former the highest point of convexity of the surface is nearer the median line than on the latter; also the posterior extremity is not so broad. 
11. expansus Arnold, deseribed by Arnold as a variety of $\boldsymbol{M}$. mathersonii Gabb, is somewhat similar in outline to $M$. merriami, n. sp., but differs in being less convex; the posterior slope is less steep and the posterior margin is not angulated as is the case of $\boldsymbol{I}$. merriami, n. sp.; the latter also lacks the radial striations seen on $M$. expansus.

It wonld seem to the writer that Arnold's $M$. mathewsonii var. expansus shonld be classed as a true species, not a variety. Arnold belongs to the section Hormomya Morch according to Dall's classification. II, mathewsonii Gabb belongs to the section Mytilus. It does not appear to be radially striated as stated by Dall in his discussion of the species of Mytilus of the Pacific Coast (Transactions of the Wagner Free Institute of Science, vol. 3, pt. 4, p. 789, 1898).

Dimensions.-Greatest antero-posterior diameter, about $104 \mathrm{~mm}$; greatest width as measured at right angles to the base, about $55 \mathrm{~mm}$; height of the depressed anterior margin, about $42 \mathrm{~mm}$.

Occurrence.-From the upper beds of the Upper San Pablo Group on the south side of Mount Diablo, University of California locality 118 .

Named in honor of Professor J. C. Merriam. Professor of Palaeontology at the University of California.

MYTILUS PERRINI, n. sp.

Plate 42 , figures 5 and 6

Shell medium in size, somewhat variable in outline, elongate subovate; beaks subacute, slightly twisted; base straight or slightly concave. Posterior cardinal angle as a rule slightly anterior to the middle of the elongate axis, the angle being obseured on some of the larger specimens, the margin posterior to the point of angulation being nearly straight and parallel or slightly diverging from the anterior edge. Ventral edge broadly rounded to subtruncate. Surface of shell covered by heavy irregular undulations with finer incremental lines. Anterior slope of surface fairly abrupt; posterior slope gentle. There is a tendency for the surface of the shell to be depressed and flattened just in front of the posterior dorsal edge. Iinge plate heavy below the beak; on some specimens the thickened hinge plate resembles somewhat the myaphoric septum of a Septifer or Dreissensia; the anterior edge of the smaller specimens is denticulate immediately below the beaks; on the smaller specimen figured at least ten of these 
minute teeth may be counted. Ligamental groove broad and fairly heavy; anterior adductor scar long and narrow.

This species is very closely allied to $\boldsymbol{U}$. edulus Linn.; it differs in having heavier lines of growth; the basal margin and posterior margin posterior to the point of angulation are nearly parallel or slightly diverging while on $\boldsymbol{M}$. edulus they are converging; the hinge plate is very much heavier and when there are teeth on the anterior margin, they are finer and more numerous; the ligamental groove also appears to be somewhat heavier.

M. perrini, n. sp., differs from $M$. mathewsonii Gabb in that the latter is a larger form; the general outlines of the two shells are different; the highest point of convexity on the surface of $M$. mathewsonii Gabb is near the middle of the shell, on $\boldsymbol{H}$. perrini it is in front of the middle; further, the posterior slopes of $M$. mathewsonii Gabb are steeper than on $\boldsymbol{H}$. perrini. The writer has been unable to get a good specimen of the hinge of $\boldsymbol{H}$. matheusonii.

II. pervini, n. sp., resembles $\boldsymbol{U}$. californicus Conrad in the fairly coarse concentric undulations; it lacks the heavy radial sculpture of $\boldsymbol{M}$. californicus; the hinge plate and outline are also quite different.

1I. perrini differs from $M$. expansus Arnold (listed by Amold as 1I. mathewsonii Gabb var. expansus, n. var.) in that it is a smaller form; the posterior dorsal margin is shorter; the surface lacks the fine radiating striae seen on $M$. expansus Arnold. In other respects the two forms seem to be quite similar; both have a broad, subtruncate ventral edge and usually a straight base, the anterior slope of the surface being quite abrupt, with the highest point of convexity well in front of the midale of the shell.

Dimensions.-Type specimen: greatest anteroposterior diameter about $57 \mathrm{~mm}$. ; greatest width measured at right angles to base, $25 \mathrm{~mm}$

Occurrence.-Upper San Pablo Group on San Pablo Bay, University of California locality 1617.

Named in honor of Professor James Perrin Smith, Professor of Palaeontology at Leland Stanford Junior University.

\section{MIYTLUS (MYTILOCONCHA) TRAMPASENSIS, n. sp.}

Plate 42, figures 2 and 3

Shell medium to large, low, slender; beaks acute, not twisted; base nearly straight, on some specimens gently concave. Cardinal angle near the middle of the elongate axis. Posterior end evenly rounded: 
anterior slope steep; surface of shell posterior to the steep anterior slope slightly convex, with a very gentle posterior slope. Surface smooth except for fine ineremental lines of growth. Hinge plate below the beaks heavy, with a deep groove anterior to the ligamental groove.

This species differs from Mytilus coalingensis Arnold in being more slender, not so broad posteriorly; the beaks are not twisted; the surface is not so high or convex, the anterior slope not being so high but possibly steeper.

Occurrence.--In the Upper San Pablo Group on Las Trampas Ridge and Rocky Ridge near southeast corner of Concord Sheet, University of California localities $38,39,1237$.

MODIOLUS GABBI, n, sp.

Plate 48 , figure 1

Modiolus multiradiatus Gabb (in part), Pal. Calif., vol. 2, p. 30, not pl. 8.

Ifodiolus multiradiatus Gabb (Smith), Proc. Calif. Acad. Sci., 4th ser., vol. III, p. 172.

Shell medium to large, elongate, anterior end extending only slightly beyond the beak. Posterior dorsal edge subangulate posterior to the mid-length of the valve. Base nearly straight with a tendency to concavity; posterior end evenly rounded. Surface sculptured by rather broad, flat-topped, dichotomous ribbing, except for an elongate, smooth, subtriangular space above the base near the anterior end; the dichotomous ribbing is more marked toward the posterior margin, while anteriorly the ribs are split only at their lower ends; interspaces slightly narrower than the tops of the ribs. Surface quite strongly convex, usually with a well-defined ridge marking the line of greater convexity extending from the beak toward the basal side of the posterior extremity; on the larger specimens this ridge is not so pronounced, the surface being more evenly rounded.

This speeies has heretofore been known as Modiolus multiradiatus Gabb, which Gabb reported from two localities, San Emideo ranch, west of Fort Tejon, and the Miocene of Contra Costa County. The type specimen without doubt came from San Emideo ranch. Some of Gabb's original material from this loeality is in the collections of the Department of Palaeontology at the University of California. The form from San Emideo ranch differs from the one in the Upper Mio- 
cene of Middle California both in outline and in seulpturing. The radial ribbing on $\boldsymbol{M}$. multiradiatus is much finer and closer together than on $M . g a b b i$; also, on the former the anterior end extends much further beyond the beak than on the latter. $\boldsymbol{M}$. multiradiatus is found in the Lower Miocene (Vaqueros) of Stone Cañon, Monterey County, and it is probably characteristic of that horizon.

Dimensions.-Greatest antero-posterior diameter, $71 \mathrm{~mm}$.; width of shell as measured from point of angulation, $30 \mathrm{~mm}$.

Occurrence,-A very common form in the lower and upper San Pablo Group; also found in the Scutella breweriana zone.

\section{CYRENA (CORBICULA) CALIFORNICA Gabb \\ Plate 56, figure 2}

Gabb in speaking of this species says:

This species is the most variable in outline of any fossil I have seen in California except the oysters and similar shells. No two specimens have the same shape and by selecting a suitable series, differences enough could be found to make three or four species, sufficiently distinct on paper. The large number of specimens, however, at my disposal, show conclusively that all belong to but one species.

C. californica is very abundant at one horizon near the top of the San Pablo Series on San Pablo Bay. Here it is just as variable as at Kirker Pass, whence it was first described; it is associated everywhere with genera that may have a brackish-water habitat. On San Pablo Bay it is associated with the following species: Mytilus perrini, n. sp., Bittium pabloensis, n. sp., Cerithium rodeoensis, n. sp., Mya dickersoni, n. sp., and Macoma pabloensis, n. sp. At Kirker Pass C. californica is associated with Littorina pittsburgensis and Trophon ponderosum.

Occurrence.-Upper San Pablo, University of California localities $1617,1942,1482,59,147,1198$.

\section{DOSINIA (DOSINELLA) ARNOLDI, n. sp.}

Plate 51, figures 1 and 2

Shell large, tumid; beaks fairly prominent; base broad; anterior extremity rather strongly produced and regularly rounded. Posterior dorsal edge long and gently arcuate; anterior dorsal edge long for this genus, nearly straight, except just below the beak, where it is slightly concave; ventral edge regular and rather strongly rounded; posterior extremity subangulate. Lunule large, deeply impressed. 
Posterior dorsal margin slightly flattened into an escutcheon-like area, which is more prominent toward the base than in the vicinity of the beaks. Surface sculptured by numerous, somewhat irregular, concentric limes. Hinge plate of left valve broad with three well developed cardinals; posterior cardinal elongated but not prominent, with small contiguous area of hinge plate roughened; anterior cardinal rather thin and high; anterior lateral strongly developed for this genus. The writer was not able to get a good specimen of the hinge of the right valve. Pallial sinus elongate, subacute. Adductor muscle impressions strong, especially the anterior one. A fairly prominent ridge is seen on the cast of the shell, extending down from the beak about half way to the ventral edge, corresponding to a broad shallow groove on the interior of the shell.

The species was found in the same horizon with Dosinia merriami, n. sp., var. diabloensis, n. var., Upper San Pablo Group, but differs from that form in that it is broader in proportion to the height; it has a longer anterior dorsal edge; the lunule is not as broad; the anterior extremity is more produced; the ventral edge is more regular and less oblique anteriorly; also the posterior dorsal edge is slightly more arcuate. The hinge plates of the two species are different; the hinge plate of $D$. arnoldi, n. sp., is narrower posteriorly and the posterior dorsal cardinal of the left valve is less prominent and lacks the corrugations seen on the corresponding tooth of $D$. merriami, n. sp., var. diabloensis, n. var.; also the second cardinal of the left valve is less elongated. Lastly, $D$. var. diabloensis lacks the marked groove seen on the inside of the shell of $D$. amoldi.

Named in honor of Dr. Ralph Arnold, who has contributed so much to the Tertiary palaeontology of California.

Occurrence.-From the Upper San Pablo Group on the south side of Mount Diablo, University of California locality 160t. Also found in Santa Margarita beds to the north of Coalinga.

DOSINIA (DOSINELLA) MERRIAMI, n. sp.

Plate 49, figures 1 and 2 ; plate 52, figures 1 and 2

Shell orbicular; heaks rather prominent, strongly prosogyrous: Innule deep and well defined. Proportion of height to length somewhat variable; on some specimens the height and length are about equal, while on others the height is greater than the length. Anterior dorsal shoulder fairly prominent, sloping out nearly at right angles 
to a line dropped from the beak to the lowest point on the ventral edge; posterior dorsal edge long and gently arcuate; posterior extremity evenly arcuate; ventral edge strongly arcuate. Surface of shell marked by concentric incremental lines, which are medium fine at the beaks, becoming coarser toward the base. Surface depressed along the posterior dorsal margin into an escuteheon-like area. Hinge plate heavy posteriorly. Right valve with four cardinal teeth; posterior cardinal elongate, weak, on some specimens examined almost obsolete and represented only by a roughened area; second cardinal elongate, deeply bifureate, the posterior lobe being the longer; third cardinal heavy, short and slightly bifurcate; anterior cardinal short and thin. Left valve with three fairly heavy cardinal teeth and one heavy, low, short, anterior lateral; the posterior cardinal is more elongate than the middle and anterior cardinals and is quite strongly corrugated on the outer side.

This species has been listed by previous writers as $D$. ponderosa Gray, a Recent form now living in the Gulf of California and very abundant in the Pleistocene of Southern California. The writer has had the opportunity of examining a considerable number of specimens of $D$. ponderosa Gray in the collections of the California Academy of Sciences at San Francisco and of the University of California. $D$. merriami, n. sp., differs from $D$. ponderosa Gray in that it is higher in proportion to the width; the posterior dorsal edge is more arcuate and more oblique, the posterior extremity being more rounding; $D$. ponderosa Gray lacks the slightly flattened surface along the posterior dorsal edge, as seen on $D$. merriami, n. sp.; also, on the latter species the beaks are slightly more prominent and the lunule is not so deeply impressed as on the former. The hinge plates of the two species are quite different; the posterior cardinal on the left valve of $D$. merriami, n. sp., is rather strongly corrugated, while on $D$. ponderosa Gray it is not; also, on the latter species the third cardinal of the right valve is not bifurcated and is higher than on $D$. merriami, and the anterior cardinal is less elongate, also the anterior lateral is more approximate to the cardinal.

Dosinia merriami, n. sp., somewhat resembles D. whitneyi Gabb, which equals Chione whitneyi Gabb (Palaeontology of California, vol. 2, p. 23, pl. 5, fig. 40), which equals D. matheresonii Gabb (Palaentology of California, vol. 2, p. 37, pl. 15, fig. 16), a species found in the Lower Miocene of California. The hinge plate of $D$. whitneyi Gabb is not known; the shell is usually not so large as $D$. merriami, n. sp., 
and the concentric lines of growth are more regular; the anterior dorsal edge slopes down more obliquely from the beaks.

Dimensions.-Height of type (pl. 49, fig. 1), $90 \mathrm{~mm}$; length, 92 $\mathrm{mm}$; diameter of one valve, about $20 \mathrm{~mm}$. Height of cotype (pl. 52 , fig. 1), $100 \mathrm{~mm}$.; length, about $85 \mathrm{~mm}$; diameter, about $23 \mathrm{~mm}$.

Occurrence.-From the base of the San Pablo Group in the region of Kirker Pass to the north of Mount Diablo. Here it is associated with Pecten crassicardo, Spisula albaria and Spisula catilliformis, Scutella gabbii, etc.; University of California locality 100. Also from the Lower San Pablo on San Pablo Bay, University of California locality 1532 .

\section{DOSINIA (DOSINELLA) MERRIAMI, var. OCCDENTALIS, n, var.}

Plate 50, figure 1

This variety differs from $D$. merriami, n.sp., ehiefly in outline; the shell is higher in proportion to the length; the posterior dorsal slope is steeper, being only slightly arcuate; the ventral margin is steeper; the anterior dorsal shoulder is less prominent; the beaks are higher and narrower. The sculpturing is very much the same as on D. merriami, n. sp., and it also has the depressed flattened area along the posterior dorsal margin. The hinge plates of the two are practically alike.

Dimensions.-Height, $88 \mathrm{~mm}$; length, $73 \mathrm{~mm}$.

Occurrence.-D. merriami, var. occidentalis comes from a higher horizon than D. merriami, n. sp.; it is found on the south side of Mount Diablo, University of California localities 481, 482, 1485, associated with Astrodapsis whitneyi, Astrodapsis tumidus, Trophon carisaensis. It is also very common in the Santa Margarita beds to the north of Coalinga.

\section{TIVELA (PACHYDESMA) DIABLOENSIS, n. sp.}

Plate 54, figures 5 and 6 ; plate 55 , figure 1

Shell large, trigonal in outline, slightly inequilateral; beaks strongly inturned. Posterior dorsal margin nearly straight to slightly concave; anterior dorsal margin straight; ventral edge long and gently arcuate; posterior dorsal margin strongly depressed, with a fairly distinct ridge or carina separating it from the remaining surface of 
the valve; this ridge gives a subtruncate effect to the posterior extremity. Anterior dorsal margin only slightly depressed. Surface smooth except for lines of growth. Three fairly heavy cardinals in right valve; anterior cardinal thin, set close to anterior, dorsal edge. Anterior cardinal of left valve heavy, not in line with the strong anterior lateral; middle cardinal bifid; posterior cardinal long, heavy, separated from the heavy nymph plate by a deep groove.

Tivela diabloensis differs from Tivela gabbi, n. sp., from the Upper San Pablo, in being longer in proportion to the height. The posterior dorsal margin is much more strongly depressed; the cardinals are not so heavy. It also differs in the presence of the carina or ridge along the posterior margin, which gives the shell a subtruncate effect, not seen on $T$. gabbi. $T$. diabloensis resembles in outline $T$. stultorum Mawe, a recent species on the West Coast, more than it does T. gabbi. The hinge, however, is very different. It differs also in the presence of the well-defined carina along the posterior margin and in the character of the anterior dorsal margin.

The writer has no material representing the species Tivela inezana, a species described by Conrad from the Lower Miocene of the San Inez Mountains. A comparison of the two San Pablo species with Conrad's meagre deseription and the figures appears to show that they are distinet specifically. They differ especially in outline and seulpturing.

Dimensions.-Type specimen (pl. 55, fig. 1), leugth, about $91 \mathrm{~mm}$; height, $61 \mathrm{~mm}$; diameter of one valve, $21 \mathrm{~mm}$. Dimensions of cotype (pl. 54, figs. 5 and 6 ), length, $60 \mathrm{~mm}$; height, $45 \mathrm{~mm}$.; diameter of valve, $13 \mathrm{~mm}$.

Occurrence,-In the Lower San Pablo Group, University of California localities $1628,1496,1273,1275,1196,1152$, etc.

\section{TIVELA (PACHYDESMA) DLABLOENSIS var, ANGULATUM, n. rar.}

Plate 56, figure 1

This form differs from $T$. diabloensis, $\mathrm{n}$. sp., which is found in the same horizon, in that it is higher in proportion to the length; it is more equilateral; the posterior dorsal margin is more strongly depressed and the carina separating the depressed area from the remaining surface of the shell is stronger. Otherwise the two forms are quite similar. 
The writer has only one good specimen of the right valve, but it is so distinct from the typical form, $T$. diabloensis, n. sp., that it appears to deserve at least varietal recognition.

Dimensions.-Height, $48 \mathrm{~mm}$; length, $58 \mathrm{~mm}$.

Occurrence-University of California locality, 1623, Lower San Pablo of the type section.

\section{TIVELA (PACHYDESMA) GABBI, n. sp.}

Plate 55, figure 2; plate 56, figures 3 and 4

Shell large, heavy, trigonal in outline; beaks subcentral, slightly posterior to the middle. Posterior dorsal edge nearly straight, on some specimens slightly concave; anterior dorsal edge slightly convex; anterior end regularly rounded; posterior end regularly rounded but not so broad as the anterior; ventral edge long and gently arcuate. Surface of valve moderately convex, smooth, except for medium fine, more or less prominent incremental lines. Left valve with three heavy, elongate cardinals; nymph plate heavy, separated from the posterior cardinal by a deep groove, which extends up to the beak; middle cardinal slightly bifid; anterior lateral heavy, elongate, not in line with the anterior cardinal. Three cardinals in right valve; the two posterior cardinals are heavy and elongate; anterior cardinal thin and situated close up to the anterior dorsal margin; here again the nymph plate is heavy and may very easily be mistaken for a cardinal; socket for lateral tooth of left valve deep and heavy; pallial sinus short and blunt; muscle impressions equal. Posterior dorsal edge strongly grooved to receive the posterior edge of the left valve.

$T$. gabbi is elosely related, if not in direct line of descent, to $T$. stultomum Mawe, a Recent species. It differs from that species in that the shell is higher in proportion to the length; the bealss are more posterior; the dorsal margins are not as strongly convex; the hinge plate is slightly heavier just above the lateral teeth; on the left valve the anterior lateral is not in line with the anterior cardinal as in T. stultorum; the nymph plate of the left valve is very prominent, while on $T$. stultorum Mawe this is almost obsolete; the anterior cardinal on T. gabbi, n. sp., is longer and heavier. A comparison of the hinge plates of the right valve of the two species shows that on T. gabbi it is somewhat heavier; the nymph plate is heavier and slightly arched upward while on $T$. stultorum Mawe it is depressed inwarl. 
T. gabbi, n. sp., differs from $T$. diabloensis, n. sp., chiefly in outline; the latter species is longer in proportion to the height, and the surface is not so strongly depressed along the posterior dorsal margin ; Tivela gabbi, n. sp., lacks the truncation on the posterior end and the obscure ridge or carina extending from the peak to the posterior extremity, which are seen on $T$. diabloensis, $\mathbf{n}$. sp.

Dimensions.-Type specimen: height, $74 \mathrm{~mm}$; length, $86 \mathrm{~mm}$; diameter of one valve, $17 \mathrm{~mm}$.

Occurrence.-A very common species in the upper San Pablo Group, University of California localities 1272, 1155, 1281, 1625, 1942, 1943,1955 , ete.

The following description of the Section Pachydesma, under Tivela is given by Dall: ${ }^{482}$ "Shell very large, elongate-trigonal with smooth interior margins, a vernicose, dehiscent periostracum, and four cardinals in each valve." After examining a great many specimens, the writer has come to the conclusion that in each valve what has been taken by Dall as the posterior cardinal is rather to be considered as a nymph plate. These oppose one another and do not alternate as true cardinals should. Thus the dental formula of section Pachydesma should be written $\frac{\mathrm{L} 010101.010}{\mathrm{R} \text {. } 101010.101}$ It may be questioned whether the section Pachydesma should not be raised to generic rank, as the genus Tivela is defined as having supplimentary cardinals.

\section{AMIANTIS (AMIANTIS) DALLI, n.sp.}

Plate 50, figure 2; plate 53, figures $1,2,3$, and 4

Shell large, heavy, inequilateral, subtrigonal to subovate in outline; height, about equal to length; beaks prominent, strongly incurved and anterior to the middle of the shell. Anterior dorsal edge gently concave; posterior dorsal edge long and gently convex; ventral edge regularly and strongly arcuate; anterior end regularly rounded; posterior end subangulate. Lunule well defined, large, wider on right valve than on left. Surface along the posterior dorsal margin strongly depressed, forming an escutcheon-like area which is separated from the main outer surface of the shell by a distinct line. Surface seulptured by heavy coneentric ridges or undulations, between and upon which are finer incremental lines; toward the beaks and on most of the surface of the shell the interspaces between the ridges are consider-

48a Wagner Free Institute of Science. Transactions, vol. III, pt. VI, p. 1244. 
ably wider than the ridges themselves, but on the adult shell the interspaces become narrower toward the base until the larger ridges are so crowded as to be indistinct. Hinge plate heavy; left valve with long, heavy nymph plate, on top of which and transversing it longitudinally is a distinct ridge. Posterior cardinal over two-thirds the length of the nymph plate, which latter is the same height as the cardinal, being separated from it only by a shallow groove; the outer edge of the cardinal and inner edge of the nymph plate show evidence of having been rugose. Middle eardinal about half as long as posterior cardinal, the space between the two being extraordinarily broad and deep. Anterior cardinal thin, about the same length as the middle cardinal, the two lying almost parallel with each other. Anterior lateral long and heavy, the top broadly rounded, the upper end connecting with the anterior dorsal margin. Right valve with a long, heavy nymph plate, which becomes thinner toward the lower end and is rugose internally. Posterior cardinal long, heavy, bifid, about two-thirds the length of the nymph plate and separated from it by a deep, elongate socket. Middle cardinal heavy, rather short and higher than the others. Anterior cardinal very thin, shorter than the middle cardinal and situated close to it; anterior lateral pit deep. Posterior dorsal edge of right valve below the ligamental area grooved to receive the corresponding edge of the left valve. Pallial sinus ample, slightly ascending and pointed in front. The impressions of two internal ridges are seen on the cast of the shell, which ridges are characteristic of the section Amiantis.

A. dalli is very closely related to $A$. callosa Conrad, a Recent species on the West Coast, showing all the minor characters described by Dall as being characteristic of the section Amiantis. (For description of genus Amiantis and section Amiantis by Dall, see Transactions of the Wagner Free Institute of Science, vol. 3, pt. 6, pp. 1257-1258.) As far as the writer is aware, this makes the second species belonging to this genus described in North America. A. dalli in comparison to A. callosa is higher in proportion to its length and the concentric undulations are more irregular. The lunule and escutcheon of the two species are very similar. The hinge plates, however, differ considerably. The nymph plate on the left valve of the latter is longer but not so high or so heavy and it lacks the longitudinal ridge seen on top of the former. On $A$. dalli the middle cardinal of the left valve is separated by a broader socket than on A. callosa. On the former the middle and interior cardinals lie nearly parallel, while on the latter they diverge at 
a considerable angle; also, the anterior lateral is longer and heavier vil the former. Other differences are seen in the comparison of the hinge plates of the two species.

Named in honor of Dr. W. H. Dall of the Smithsonian Institution.

Dimensions.-Type specimen: height, $57 \mathrm{~mm}$.; length, about 56 $\mathrm{mm}$. Height of co-type (pl. 50, fig. 2), about $70 \mathrm{~mm}$.

Occurrence.-From the Upper San Pablo Group, University of California locality 38.

Found in association with Astrodapsis whitneyi, Macoma secta, Mytilus trampasensis, Solen perrini, Venus martini, Mulinia pabloensis, Neverita pabloensis, Trophon carisaensis.

\section{PITARIA BEHRI, n. sp.}

Plate 54, figures 2,3 , and 4

Shell subtrigonal in outline; beaks prominent, strongly incurved; lunule large, depressed and slightly wider in right valve than in left. Anterior dorsal edge short and rather deeply concave; posterior dorsal edge nearly straight, about twice as long as the anterior dorsal edge; ventral edge strongly areuate; posterior and anterior ends evenly rounded. Surface of shell rather strongly depressed along the posterior dorsal margin, but there is no well-defined line separating this narrow depressed area from the remaining portion of the shell. Surface of shell sculptured by somewhat irregularly spaced, sharp, concentric lamellae. Posterior cardinal long and narrow, middle eardinal heavy and high; anterior cardinal thin, not so high as middle cardinal; anterior lateral prominent. Hinge plate of right valve not known.

This species somewhat resembles in outline Cytheria diabloensis Anderson, ${ }^{ \pm 9}$ from which it differs in the following respects: It does not have so prominent ribbing; the hinge plate as compared to Anderson's figure is different.

Named in honor of Mr. Ernest Behr, the collector of the specimen described.

Dimensions.-Type specimen: height, $62 \mathrm{~mm}$; width, about 70 $\mathrm{mm}$.; diameter of both valves, about $37 \mathrm{~mm}$.

Occurrence.-In the upper part of the Lower San Pablo Group on San Pablo Bay, associated with Dosinia merriami, n. sp., Pitaria stalderi, n. sp., Chrysodomus pabloensis, n. sp., Ficus, ef. stanfordensis Arnold, University of California localities 1279, 1532, and 1600.

49 Anderson, F. M., "A stratigraphie study in the Mount Diablo Range of California," Proc. Calif. Acad. Sei., 3rd Series, vol. 2, no. 2, p. 1960, pl. XIII, figs. $83-85$. 
PITARIA STALDERI, n. sp.

Plate 53, figures 5 and 6

Shell elongate, subovate; beaks prominent, strongly inturned. Linnule large, well defined, depressed, wider on right valve than on left. Anterior dorsal edge slightly concave, about two-thirds the length of the posterior dorsal edge; posterior dorsal edge long, straight; posterior end broadly rounded; anterior extremity quite strongly produced, and evenly rounded; ventral edge long and gently arcuate. Surface of shell sculptured by medium coarse, irregular, concentric, fairly sharp incremental lines. Posterior eardinal tooth of left valve long, situated on top of long, narrow nymph plate; middle cardinal high and thin; anterior cardinal thin but not so prominent as middle cardinal; anterior lateral prominent. Posterior cardinal of right valve long, situated on anterior edge of long nymph plate, grooved toward anterior end; middle cardinal not prominent, slightly bifid; anterior eardinal very thin, situated close up to the middle cardinal.

$P$. stalderi differs from $P$. behri, found in the same horizon, in being more elongate; the anterior extremity is more produced; the ventral edge is less arcuate, the posterior extremity is broader, and it lacks the strongly depressed area along the posterior dorsal edge, the incremental lines of growth do not stand out so prominently or so regularly as on $P$. behri. The hinge plates of the two species are quite different. The middle cardinal tooth on $P$. behri, n. sp., is much heavier, and the platform on which the anterior laterial rests on $Y$ behri is wider than on $P$. stalderi.

Named in honor of Mr. Walter Stalder.

Dimensions.-Length of type (pl. 53, fig. 6), about $67 \mathrm{~mm}$.; height, $52 \mathrm{~mm}$.

Occurrence,-From the Lower San Pablo Group on San Pablo Bay, University of California localities 1279, 1532 and 1524.

\section{CHIONE DIABLOENSIS, n. sp.}

\section{Plate 58, figure 4}

Shell medium in size, roughly quadrate in outline; beaks anterior to the middle of the shell, fairly prominent, rather strongly inturned. Posterior dorsal edge gently areuate; anterior dorsal edge nearly straight; posterior end subtruncate; anterior end evenly rounded; ventral edge regularly arcuate. There is a long, narrow escutcheon 
on the posterior dorsal edge, which is nearly at right angles to hinge plate. Lunule large, elongate, slightly depressed, smooth. Surface of shell sculptured by medium coarse to fine radiating ribs, the interspaces between which are about equal to or slightly wider than the tops of the ribs; posteriorly and anteriorly the ribbing becomes finer and closer together, becoming obsolete on approximately the posterior one-fifth of the shell; surface of shell also covered by rather heavy concentric lines of growth.

The sculpturing of this species resembles rather closely that of $C$. securis Shumard, but the ribbing is finer and the beaks are not so prominent. It differs radically in the outline and in the narrower escutcheon. This species could very easily be mistaken for Paphia staminea Conrad, a common species in the San Pablo also living on the west coast.

There is a very marked difference in outline between this species and $C$. pabloensis, n. sp., also of the San Pablo Group; the radial ribbing, however, is similar, as is also the escutcheon.

Dimensions.-Length, $42 \mathrm{~mm}$; height, $21 \mathrm{~mm}$.

Occurrence.-In the Upper San Pablo Group to the east of the town of Walnut Creek, University of California locality 1492.

\section{CHIONE PABLOENSIS, $\mathrm{n}, \mathrm{sp}$.}

Plate 58; figure 2, also figure 18

Shell elongate ovate to subtrigonal in outline; beaks prominent and strongly incurved, about one-fifth the length of the shell from the anterior end. Lunule large, not strongly depressed, sculptured only by concentric striae; escutcheon strongly depressed and sharply defined as an elongate area extending from the beak to very nearly the ventral edge. concentrically striated only. Posterior dorsal edge long, gently arcuate; anterior dorsal edge short, gently concave; ventral edge long and regularly arcuate; posterior end regularly rounded; anterior end regularly rounded, quite strongly produced. Ventral edge and anterior dorsal edge crenulate. Surface seulptured by welldefined radial ribbing, with interspaces as wide or wider than the tops of the ribs; the radial ribbing is rather fine, and somewhat irregular, becoming finer on anterior portion of shell and obsolete near the posterior margin; surface also sculptured by rather prominent ineremental lines; the pallial sinus is fairly strong for this genus, and is $\mathrm{V}$-shaped. Hinge plate unknown. 
This species is very elosely allied to Chione securis Shumard (Venus securis Shumard, Transactions St. Louis Acad. Sci., no. 2, p. 122, 1858; also, U. S. G. S. Professional Paper, no. 59, p. 120, pl. XI, fig. 8; pl. XIII, fig. 289). C. pabloensis differs from (t. securis Shumard in being more elongate; the ribbing is finer and the escutcheon is more sharply defined.

Dimensions.-Height of shell, $53 \mathrm{~mm}$; length of shell, $72 \mathrm{~mm}$; diameter of both valves, $35 \mathrm{~mm}$.

Occurrence.-Upper San Pablo Group on the south side of Mount Diablo, University of California locality 1485.

VENUS MARTINI, n. sp.

Plate 54, figure 1

Shell medium in size, suboval, inequilateral, equivalved. Beaks fairly prominent, strongly inturned. Lunule lacking but with an obscure, elongate depressed escutcheon-like area along the posterior dorsal edge. Anterior dorsal edge rather short, slightly concave; posterior dorsal edge long and nearly straight; ventral edge regularly and gently arcuate; posterior end broadly and evenly rounded; anterior end evenly rounded. Surface of shell sculptured by heavy, prominent, rounded regular concentric undulations with interspaces averaging about as wide as the undulation. The interspaces and the undulations are covered by fine incremental lines. The hinge plate of left valve was exposed showing three well developed cardinals with no anterior lateral. Pallial sinus unknown.

This species resembles closely $V$. pertenuis Gabb in sculpturing but differs quite radically in outline, the latter being more trigonal and less elongate. $V$. pertenuis is common in the Lower Neocene and in the Santa Margarita of the north of Coalinga. In the latter horizon it is associated with $V$. martini.

Named in honor of Mr. Bruce Martin, formerly Assistant Curator of Palneontology of the California Academy of Science, San Franciseo.

Dimensions.-Length, about $63 \mathrm{~mm}$. ; height, about $50 \mathrm{~mm}$. ; diameter of both valves, $33 \mathrm{~mm}$.

Occurrence.-From the Upper San Pablo Group usually associated with Astrodapsis whitneyi, University of California Iocalities 181, 741, 
482 and 125. Also found in the Santa Margarita to the north of Coalinga, where it is also associated with Astrodapsis whitneyi.

\section{PETRICOLA BUWALDI, n. sp.}

Plate 60, figure 6

Shell subquadrate; beak low and inconspicuous; hinge line, including the anterior and posterior dorsal edges, nearly straight. Posterior dorsal edge nearly twice as long as anterior dorsal edge; anterior end broadly rounded, sloping nearly at right angles to the ventral and anterior dorsal edges; posterior end regularly and broadly rounded; ventral edge very gently arcuate. Surface sculptured by broad, flat-topped, somewhat obscure, radiating ribs with narrow interspaces. Two eardinals in left valve, the posterior cardinal being slightly bifid. Extermal ligamental groove short; anterior to this and not sharply separated from it is a rather broad, elongate, triangularshaped resilifer.

Named in honor of Dr. John P. Buwalda.

Dimensions.-Length, $29 \mathrm{~mm}$; height, $25 \mathrm{~mm}$; diameter, $9 \mathrm{~mm}$.

Occurrence.-A single specimen of a left valve was found in the Upper San Pablo Group to the southeast of the town of Walnut Creek, University of California locality 1942.

\section{TELLINA? DIABLOENSIS, 21. sp.}

Plate 61, figure 5

Shell subtrigonal to quadrate in outline, subrostrate posteriorly, more ventricose posteriorly than anteriorly. Beak inconspicuous, posterior to center. Anterior dorsal edge very gently curved; posterior dorsal edge straight; ventral edge regularly rounded, rather convex; posterior end bluntly pointed; anterior end broadly and evenly rounded. Surface covered by fairly prominent irregular incremental lines, depressed along the posterior dorsal margin but with no well defined line marking the anterior edge of depression. Ligamental groove short; hinge plate fairly heavy, with well-developed nymph, resembling that on a Sanguinolaria; one prominent bifid posterior cardinal tooth; anterior cardinal either obsolete or broken. Anterior to the beak there is an elongate lateral troth; the distance between 
the lateral tooth and the anterior dorsal edge suggests that there was a lateral on the left valve which fitted in between the two.

Dimensions.-Length of shell, $28 \mathrm{~mm}$.; height of shell, $29 \mathrm{~mm}$.

Occurrence.-In the Upper San Pablo Group to the southeast of the town of Walnut Creek, University of California locality 1478. Only one specimen of the right valve of this species has so far been found.

\section{TELLINA ENGLISHI, n. sp.}

Plate 61, figures 6 and 7

Shell elongate-subovate, compressed, inequilateral, rostrate posteriorly. Beaks inconspicuous, posterior to the center with a narrow, deep lunule. Right valve flatter than left and flexed near the posterior end. Anterior end evenly rounded, anterior dorsal edge straight, and nearly parallel with the ventral edge; posterior dorsal edge straight, sloping more steeply from the beak than anterior dorsal edge; ventral edge long, very gently arcuate except at point of flexure, where it is slightly incurved. Posterior to the flexure on the surface there is a prominent raised ridge which extends obliquely from the beak to the posterior extremity and parallel to the posterior dorsal edge; beyond this ridge and parallel with it, is a well-defined groove. Left valve sculptured by finer concentric lines than right valve, and corresponding to the posterior ridge seen on the right valve there is a groove situated very close to and parallel with the posterior dorsal edge; there is no well-defined line in front of this groove.

Tellina englishi resembles closely Tellina idae Dall, a Recent species on the West Coast. The former differs from the latter in the following respects: the anterior dorsal edge is straighter and longer; the beaks are more posterior; the shell is longer in proportion to the height, and the ventral edge is less arcuate. Tellina cnglishi is also very close in resemblance to Tcllina tenuistriata Davis, a species described by C. II. Davis (Jour. of Geol. vol. 21, no. 5, p. 457, fig. 7). The writer has seen some very good specimens in the California Academy of Sciences in San Francisco, which are without doubt referable to this latter form. This species though resembling the San Pablo form is easily distinguishable from it. The posterior end of the lower Miocene form is apparently more attenuate; the posterior dorsal slope is not so steep; the rentral edge is more arcuate and the shell is higher in proportion to the length. 
Named in honor of $\mathrm{Mr}$. Walter English.

Dimensions.-Length, $40 \mathrm{~mm}$; height, $21 \mathrm{~mm}$.

Occurrence.-From the Upper San Pablo Group on the south side of Mount Diablo, University of California locality 481.

\section{TELLINA HANNIBALI, n. sp.}

Plate 61, figure 11

Shell medium in size; beaks inconspicuous, posterior to the middle. Anterior dorsal margin nearly straight, becoming slightly convex toward the anterior extremity; posterior dorsal edge slightly convex, the greatest amount of convexity coming just in front of the posterior extremity; posterior extremity pointed; anterior end regularly rounded; ventral edge gently and regularly arcuate. Along the posterior edge there is a narrow depressed marin which is separated from the remaining portion of the surface by a fairly distinct line. Surface smooth, except for irregular incremental lines.

This species resembles $T$. merriami Weaver from the Miocene of Washington. The writer has only one specimen of a right valve, and more material may possibly show that it grades into that species.

Named in honor of Mr. Harold Hannibal.

Dimensions.-Length, $35 \mathrm{~mm}$; height, $23 \mathrm{~mm}$.

Occurrence.-From the Upper San Pablo to the southeast of the town of Walnut Creek. University of California locality 1942.

\section{MACOMA ANDERSONT, n. sp.}

Plate 61, figure 19

Shell elongate, subovate; beaks posterior to middle, inconspicuous. Posterior dorsal edge slightly concave along ligamental groove, beyond this nearly straight to slightly convex; anterior dorsal edge long and gently convex; anterior end evenly rounded; posterior end bluntly pointed; ventral edge gently convex anteriorly and nearly straight posteriorly. On left valve along posterior margin is a narrow depressed area, which is only obscurely separated from the main surface of the valve; it widens quite perceptably below the ligamental groove into a flange, somewhat similar to though not so wide or distinet as the flange seen on the posterior edge of $M$. secta Conrad, a Recent species and one which is also found in the same horizon; right valve 
slightly flexed and with posterior margin more strongly depressed than on left. Ligamental groove less than half the length of posterior dorsal edge. Surface of valves covered by fine incremental lines and occasional lines of interrupted growth.

$\boldsymbol{I}$. anderson $\boldsymbol{i}$ is of the same general type as $\boldsymbol{H}$. indentata Carpenter, a Recent species on the West Coast; it differs in that the ventral edge is not so areuate, and does not have the distinct concavity seen on the latter along the line of flexure; otherwise the two forms are very close and possibly the one should be called a variety of the other. This difference, however, appears to be quite constant; therefore the writer has given the San Pablo form specific rank.

$\boldsymbol{M}$. andersoni is found in the same general horizon as $\boldsymbol{M}$. diabloensis, n. sp. It differs from that species in the following respects: it is longer in proportion to the height; the right valve is not so strongly flexed nor so strongly depressed along the posterior dorsal margin. II. diabloensis lacks the distinct flange along the posterior dorsal margin, seen on $1 \%$. andersoni. In this respect the former is more closely related to $\boldsymbol{H}$. nasuta Conrad and $\boldsymbol{H}$. inquinata Deshayes, while the latter resembles $\boldsymbol{H}$. secta Conrad and $\boldsymbol{H}$. indentata Carpenter. Again, the ligamental groove is proportionately longer on $M$. diablocnsis than on $M$, andersoni.

II. andersoni somewhat resembles $M$. van:lecki Amold from the Etehegoin, which is also of the same general type as $\boldsymbol{M}$. indentata. It differs, however, in that the depressed posterior margin is narrower and is not sharply defined by a carina as is the case with $\boldsymbol{M}$. vanvlecki; the posterior flexure of the right valve is not so great; the ventral edge is straighter, lacking the strong concavity along the line of flexure seen on $M$. vanvlecki. This last species appears to be more elosely related to $\boldsymbol{M}$. indentata than does $\boldsymbol{M}$. andersoni.

Named in honor of MIr. F. M. Anderson, curator of Palaeontology in the IIuseum of the California Academy of Sciences, San Francisco.

Dimensions.-Length, $31 \mathrm{~mm}$; height, $20 \mathrm{~mm}$; diameter, about $5 \mathrm{~mm}$.

Occurrence.-This is a fairly common speeies in the Upper San Pablo Group. It has been found in the San Pablo Bay section, on the south side of Mount Diablo and in the Tice Valley Syncline. University of California localities 1470 (type), 1227, 749 , ete. 


\section{IIACOMIA DIABLOENSIS, n. sp.}

Plate 61 , figures 8,9 , and 10

Shell medium in size, subtrigonal in outline; beaks low, nearly central. Left valve slightly more convex than right. Anterior dorsal edge slightly arcuate; posterior dorsal edge straight; posterior extremity bluntly pointed; anterior end evenly rounded; ventral edge gently and evenly arcuate. Right valve flexed near the posterior extremity; posterior dorsal margin strongly depressed, the narrow depressed area being nearly at right angles to the main surface of the valve and separated from it by a well-defined line; on this narrow, depressed area is a faint groove which does not reach to the beak. Left valve near the posterior extremity bent to the right; posterior margin not depressed. Surface of shell smooth, except for more or less prominent concentric lines of growth. Ligamental groove long, of the $M$. nasuta type; interior unknown.

$\boldsymbol{M}$. diablocnsis differs quite radically in ontline from $\boldsymbol{M}$. nasuta Conrad, a Recent species; the beaks are more central; the posterior extremity is not truncated and the depressed dorsal margins are very different.

I. diabloensis resembles quite closely in outline $\boldsymbol{M}$. astori Dall ("Miocene of Astoria and Coos Bay, Oregon," U. S. G. S. Prof. Paper, no. 59, pl. 14, figs. 1, 11), but differs from it in the character of the depressed posterior dorsal margin; also the shell is not so large.

For a comparison of $\boldsymbol{H}$. diabloensis with $\boldsymbol{M}$. andersoni, n. sp., found in the same horizon, see the deseription of the latter.

II. diabloensis differs from $\boldsymbol{M}$. calcarea Gmelin in the character of the posterior dorsal margin, and in that the beaks are more central.

Dimensions.-Type specimen: left valve, height, $22 \mathrm{~mm}$; length, $27 \mathrm{~mm}$; diameter, $3 \mathrm{~mm}$. Co-type, right valve : height, $21 \mathrm{~mm}$.; length, $29 \mathrm{~mm}$; diameter, $2 \mathrm{~mm}$.

Occurrence.-A common species in the Upper San Pablo Group on the south side of the Mount Diablo anticline, University of California localities 763,1513 , etc.

\section{MACOMA PABLOENSIS, n. sp.}

Plate 61, figures 1, 2, and 17

Shell small, sub-equilateral, subtrigonal in outline; beaks inconspicuous and central. Anterior dorsal edge very slightly arcuate: posterior dorsal edge straight; ventral edge regularly and rather 
strongly arcuate; posterior end bluntly pointed; anterior end broadly and evenly rounded. Surface of valves marked by medium fine incremental lines. Right valve slightly flexed near the posterior extremity; bordering the posterior dorsal edge is a narrow depressed area on which is a faint groove extending from the posterior extremity about half way to the beaks; this depressed area is separated from the remainder of the surface by a raised line or ridge. Left valve with an obseure, narrow, posterior depressed area on which there is usually a faint groove corresponding to the groove seen on the depressed area of the right valve. Shell near the posterior end slightly twisted to the right. Ligamental groove rather long, about half the length of posterior dorsal edge. Of the two cardinal teeth in right valve, the posterior cardinal is the larger and is bifid; in the left valve the anterior eardinal is the larger and is bifid.

Dimensions.--Type specimen: length, $13 \mathrm{~mm}$; height, $13 \mathrm{~mm}$; diameter of both valves, $8 \mathrm{~mm}$.

Occurrence.-This species is found at several localities in the Upper San Pablo Group on the south side of Mount Diablo and in the type section on San Pablo Bay; also on Rocky Ridge and Las Trampas Ridge, University of California localities 1671, 767 and 400.

\section{SANGUINOLARIA ALATA Gabb}

Plate 61, figure 14; plate 62, figure 5

Gari alata Gabb. Palaeontology of California, rol. 2, p. 21, pl. 5, fig. 36, 1869.

Shell oval, equivalved, inequilateral, compressed; beaks inconspicuous; nymph plates very prominent; beaks slightly anterior to the middle of the shell. Anterior dorsal edge straight; anterior end evenly rounded; posterior dorsal edge longer than anterior and slightly concave and straight; base evenly and gently arcuate; posterior end evenly rounded. A very strong nymph plate on each valve extending over two-thirds the length of the posterior dorsal edge with a marked longitudinal groove on each, rumning along their entire length. 'T'wo cardinal teeth in each valve, anterior cardinals more prominent than posterior; anterior cardinal of left valve bifid, posterior cardinal elongate, not so high and slanting obliquely toward the rear; anterior cardinal of right valve not bifid, posterior eardinal elongate and bifid. IV. II. Dall (Transactions of the Wagner Free Institute of Science. vol. 3 , pt. 5, p. 974), in referring to this species says: "The super- 
ficial appearance of Gari alata Gabb is that of a Sanguinolaria." The study of the dentition leaves no doubt of the generic determination.

S. alata differs from S. nuttallii Conrad, a Recent species, as follows: the shell differs in outline; it is equivalved, while $S$. nuttalli is inequivalved; the nymph plate is longer and more conspicuous.

Gabb in his description of this species deseribed the anterior end for the posterior.

Occurrence.-In the Lower San Pablo Group, two miles east of Kirker Creek, north of Mount Diablo, University of California locality 62. Also on the west side of Mount Diablo, on south side of Shell Ridge, University of California locality 351. So far this species has been found only in the Lower San Pablo.

\section{SANGUINOLARIA?, sP.}

Plate 61, figure 13

Shell medium in size, elongate, subovate in outline; beaks inconspicuous, anterior to the middle; anterior dorsal edge slightly convex; posterior dorsal edge nearly straight; anterior and posterior ends evenly rounded; ventral edge long and regularly areuate; surface of valve very slightly convex. Shell smooth, except for more or less prominent incremental lines. Ligamental groove rather short, with a nymph plate extending along its entire length; the nymph plate is a little higher than the dorsal edge; it is somewhat of the type of the nymph plate on S. nuttallii Conrad, a Recent species on this coast; hinge plate unknown.

Dimensions.-Length, $27 \mathrm{~mm}$; height, $18 \mathrm{~mm}$; diameter of one valve, about $2 \mathrm{~mm}$.

Occurrence.-One specimen known, from the Upper San Pablo Group of the San Pablo Bay section, University of California locality 1617.

\section{SOLEN PERRINI, n. sp.}

Plate 44, figure 2

Shell straight, rather heavy; posterior extremity broadly rounded, anterior extremity truncated, the margin of which joins the posterior dorsal edge at an angle of a little more than $90^{\circ}$; well-defined groove or flexure parallel and close to the anterior dorsal edge. (This flexure on some specimens is more pronounced than on others.) 
This species sometimes has a length of six to eight inches and a height of from one inch to one and one-half inches. It is the most common Solen in the Miocene and Pliocene of California. It has been listed by various writers as Solen sicareus Gould and Solen rosaceus Cpr. It differs from $S$. sicareus in that both the posterior dorsal edge and the ventral edge are straight. S. sicareus shows a slight concavity along the posterior dorsal edge, while the ventral edge is slightly convex. Also S. sicareus has very little, if any, flexture on the anterior end. $S$. perrini resembles $S$. rosaceus more closely than $S$. sicareus. It differs in that it is a heavier shell; and it is higher in proportion to its length.

Named in honor of Professor James Perrin Smith of Leland Stanford Junior University.

Locality.-Upper and Lower San Pablo Group.

\section{MYA DICKERSONI, n, sp.}

Plate 63, figures 3 and 4

Shell somewhat variable in outline, elongate-subovate; beals inconspicuous, usually anterior to the middle of the shell. Valves more ventricose anteriorly than posteriorly; posterior end truncated; anterior end evenly rounded; posterior dorsal edge long, nearly straight, on some specimens slightly coneave; anterior dorsal edge gently arcuate; ventral edge long, very nearly straight, almost at right angles to the trumeated edge of the posterior end. Surface of valves rather strongly excavated anterior to the beaks; covered by rather coarse undulations on and between which are finer incremental lines; chondrophore large with a prominent radiating ridge near the posterior edge projecting beyond the edge even more prominently than is the case with the same ridge on Mya arenaria Linné, a Recent species.

II. dickersoni differs from $\boldsymbol{H}$. japonica Gould and $\boldsymbol{M}$. arenaria Linné, both Recent species, in that it is truncated posteriorly and the ventral edge tends to be less arcuate.

II. dickersonii resembles $\boldsymbol{H}$. truncata, a Recent species, in that it is truncated posteriorly nearly at right angles to the ventral edge. It differs in being more elongate; the anterior end is not so broadly rounded, and the posterior end is narrower; the posterior dorsal slope is longer; the posterior ridge on the chondophore extends out beyond the edge, on $\boldsymbol{M}$. truncata it does not. 
Named in honor of Dr. R. E. Dickerson, assistant eurator of Palaeontology in the California Academy of Sciences, San Franciseo.

Dimensions.-Type specimen: length, $57 \mathrm{~mm}$; height, $37 \mathrm{~mm}$.

Occurrence.-A very common species in the Upper San Pablo Group. Found associated in almost every locality with Cyrena californica Gabb, Macoma pabloensis, n. sp., Mytilus perrini, n. sp., Bittium? pabloensis, n. sp., Cerithium rodeoensis, n. sp. University of California localities $16,17,1618,1478,1224,1227,1514$, etc.

\section{MYA (CRYPTOMYA) OVALIS Conrad}

Plate 60, figures 3 and 4

Cryptomya ovalis Conrad, Proc. Acad. Nat. Sei. Phil., vol. 8, pp. 312-316, 1856.

Cryptomya ovalis Conral, Pac. K. R. Rept., vol. 6, pt. 2, no. 2, pp. 69-73, 1857.

The following is the original deseription of Cryptomya ovalis:

Oval, compressed, posterior end truneated, umbonal slope angulated on the umbo; beak medial; basal margin medially truncated; disk medially flattened.

Locality.-Monterey, Calif. Dr. Newberry.

The species 11 . ovalis, as listed by the writer from the San Pablo group, does not correspond very elosely to Arnold's figure of Cryptomya ovatis Conrad from the Etchegoin (Bull. U. S. G. S. 398, pl. fig., also Bull. U. S. G. S. 396, pl. fig.). It would appear that Arnold's M. ovalis does not differ very radically from $M$. californica, the Recent species. $\boldsymbol{H}$. ovalis of the San Pablo group corresponds very well to Conrad's meagre description and the cut seen in the Pacific Railroad Report, vol. 6. It differs from $\boldsymbol{H}$. califorvica in having more prominent beaks; the posterior end is truncated more nearly at right angles with the ventral edge. The umbonal slopes stand out very prominently; the fold running down from the beaks to the ventral angle of the posterior extremity is more prominent; there is also a faint corresponding ridge or fold running down from the beak to the anterior extremity and the medium surface of the shell is flattened.

Occurrence.-A very common species in the San Pablo Group. 


\title{
G.ASTROPODA
}

\author{
ASTRALIUM RAYMONDI, n. sp.
}

Plate 65, figures 15 and 16

Shell large; spire elevated; apex acute; whorls gently convex, six or seren in number: body whorl about equal in height to the spire; base nearly flat; sutures appressed. Whorls highly ornamented; body whorl sculptured by about twenty-two longitudinal, slightly oblique ribs which reach from the suture down to about half the height of the whorl; between the base and the longitudinal ribbing are two strong spiral rows of elongate, oblique nodes; the nodes in each row are opposite each other and alteruate with and are equal in number to the longitudinal ribs. Base sculptured by four heavy revolving ribs which show a tendency to be nodose. Whorls of spire sculptured similarly to body whorl, except that the lower of the two rows of oblique nodes on each whorl is partially concealed by the whorl below; outer lip thin. Peristome nearly round, discontinuous; umbical tract bounded by a broad; shallow groove.

This species resembles rather elosely in sculpturing and in outline A. undosa Wood, a Recent species on this coast. A. undosa has the two rows of nodes near the base of each whorl, with a similar system of longitudinal ribbing, but it differs in that the lower row of nodes is more prominent and becomes so joined that they might be considered as a nodose ridge rather than as a distinct row of nodes; this lower prominent nodose ridge gives a collar-like effect to the lower part of each whorl, which is not seen on $A$. raymondi. n. sp. On $A$. undosa there is a node at the lower end of each longitudinal rib, not seen on $A$. raymondi. The whorls of $A$. raymondi are more convex than on A. undosa Wood, and the base of the body whorl is not so flat.

Named in honor of Professor W. J. Raymond of the University of California.

Dimensions.-Type specimen : height, about $32 \mathrm{~mm}$, greatest width of body whorl, $44 \mathrm{~mm}$.

Occurrence.-A very common species in the Upper San Pablo Group above the Astrodapsis whitneyi zone; usually found associated with Tivela gabbi, n. sp. 


\section{LEPTOTHYRA DANVILLENSIS, n. sp.}

Plate 65, figures 11 and 12

Shell conical, about as high as the greatest width of the body whorl; whorls regularly and quite strongly convex. Number of whorls six; base of body whorl flattish but with no sharp line of angulation between the sides and the base; suture deeply depressed. Whorls of spire sculptured by eight or nine fairly prominent, narrow, concentric ribs with interspaces nearly twice as wide as the tops of the ribs; on the sides of the body whorl there are eight concentric ribs; the base of the whorl is seulptured by thirteen or fourteen concentric ribs, which are finer than those on the sides of the whorl; aperture round.

This appears to be the first species of this genus reported from the Miocene of the West Coast. There are three Recent species of Leptothyra on the coast of California; these are $L$. bacula Carpenter, $L$. carpenteriana Pilsbury and $L$. paucicostata Dall. Of these three species, $L$. danvillensis most resembles $L$. carpenteriana. It differs from that species in that it is larger and the spire is higher; the base is flatter; the concentric ribbing is more regularly interspaced; the interspaces are wider; the sculpturing on the base of the body whorl is finer.

Dimensions.-Type specimen: height of shell, $11 \mathrm{~mm}$; greatest width of body whorl, $11 \mathrm{~mm}$.

Occurrence.- In the San Pablo Group about one mile to the south of Danville to the west of the County Road, University of California locality 323 .

\section{CALLIOSTOMA BICARINATUM, n. sp.}

Plate 65, figures 14 and 19

Shell conical; apex acute; body whorl about as high as spire; sides of whorls convex; sutures depressed. Upper part of body whorl sculptured by about thirteen elongate, oblique nodes, some of which on the type specimen are rather obscure; between the base and the oblique nodes are two prominent spiral ribs, which are separated from each other with an interspace about equal to the tops of the ribs; the upper spiral rib has a tendency to be nodose. Base of body whorl flat, at right angles to the sides and sculptured by four fairly prominent revolving ribs, the inner two of which are closer together than the outer. Whorls of spire senlptured similarly to body whorl, except that on each whorl the lower of the two side spiral ribs is covered by the whorl 
below. Peristome subquadrate; shell pseudo-umbilicate and with fairly heavy eallus just posterior to peristome.

Dimensions.-Type specimen : height, about $15 \mathrm{~mm}$.; greatest width of body whorl, $16 \mathrm{~mm}$.

Occurrence.-University of California locality 1182; found associated with Tivela gabbi, Bittium trampasensis, Astralium raymondi, ete.

CALLIOSTOMA SPLENDENS Cpr. var. DIABLOENSIS, n. var.

Plate 65, figure 21

Shell conical, medium in size; spire moderately high; whorls seven. angulated a little posterior to middle, with the surface between the angulation and the suture subtabulate, and slightly sloping. Sutures impressed; base of body whorl nearly flat; sides of whorls nearly flat: junction between side of body whorl and base subangulate. Surface of whorls seulptured by medium fine, nodose or beaded, revolving ribs, with interspaces wider than the tops of the ribs; between the angulation of the whorl and the suture there are two revolving ribs with riblets in the interspaces: on the sides of the body whorl there are five revolving ribs, usually with a finer revolving, unnodose riblet between. On the base of the body whorl there are seven revolving ribs similar to those on the side -here also a faint interriblet may be seen. On the sides of the whorls of the spire there are three revolving ribs. Mouth subquadrate; shell imperforate.

This variety differs from the species $C$. splendens Carpenter, a Recent species, in having the whorls more strongly angulated and tabulated; the ribbing and nodes are slightly coarser, the interspaces between the ribs being greater and there are fewer revolving ribs between the angulation of the whorls and sutures.

Dimensions.-Height of shell, $10 \mathrm{~mm}$; ; greatest width of shell. $10 \mathrm{~mm}$.

Occurrence.-In the Middle and Upper San Pablo Group of Kirker Pass, also from the Upper San Pablo Series to the southeast of Walnut Creek, University of California localities 102, 350 and 1890.

TEGULA (CHLORASTOMA) DANVILLENSIS, n. sp.

Plate 65, figures 17 and 18

Shell depressed, conical, fairly heavy ; apex broken on type specimen. Number of whorls five, possibly six. Sutures depressed; sides of whorls nearly flat, the upper part of the whorl being subtabulate; 
the subtabulation is strongest on the body whorl; base of body whorl flattish, the whorl being angulate at the juncture of the sides with base. First whorl of spire sculptured by five equally spaced, fairly prominent, narrow spiral ribs, the interspaces between which are about twice as wide as the ribs; besides the major spiral sculpturing finer spiral lines may be seen with the aid of a lens, covering both the major ribs and the interspaces. The major spiral ribbing on the sides of the body whorl is crossed by fifteen or sixteen obliquely sloping, fairly heavy, longitudinal ribs; this longitudinal ribbing is more prominent toward the anterior part of the body whorl but becomes less distinct posteriorly and is not visible on the whorls of the spire. The flat base of the body whorl is covered by fine spiral ribs with very narrow interspaces. Around the edge of the open umbilicus there is a narrow area which is smooth. Aperture subquadrate; umbilicus open, fairly broad.

On a smaller specimen of what appears to be undoubtedly the same species and found at the same locality, there is no longitudinal ribbing visible on the body whorl; the spiral ribbing is similar to that seen on the first whorl of the spire of the type speeimen; on the base, besides the finer sculpturing, there are two heavier ribs close to the umbilieus.

Dimensions.-Height, about $9 \mathrm{~mm}$; greatest diameter of body whorl, $13 \mathrm{~mm}$.

Occurrence.-Found in the San Pablo Group about one mile south of the town of Danville, on the north side of Las Trampas Ridge, University of Califormia locality, no. 323.

\section{'TEGULA (CHLOROSTOMA) NASHI, n.sp.}

Plate 65, figures 6 and $\tau$

Shell conical, fairly heavy; whorls five; body whorl slightly broader than the height of the shell; sutures strongly impressed; surface of whorls slightly convex; body whorl angulate between sides and base. Base flattened with a broad, deep, spiral groove situated about half way between the angulation and the umbilicus. On the body whorl just above the angulation there are two prominent spiral ribs; on each whorl of the spire, only one spiral rib is visible and this is situated just above the suture. Extending from the suture to the posterior spiral rib of the basal whorl are about twelve oblique longitudinal ribs; this longitudinal ribbing is also present on the last whorl 
of the spire but on the earlier whorls it becomes obsolete. Surface of shell also covered by fine spiral lines, which pass over both the heavy spiral and longitudinal ribs; on the base of the body whorl this finer ribbing appears to extend only to the single spiral groove, the surface being smooth, between the groove and the umbilicus. Aperture subquadrate in outline; outer lip thin; umbilicus open; on the inner lip there is a fairly strong tubercle.

It is interesting to note that on the type specimen some of the original color markings of the shell are preserved; on the base of the whorl is a series of narrow, transverse, brownish stripes, radiating outward from the umbilicus and extending obliquely onto the upper part of the whorl in opposite direction to that of the longitudinal ribs. $T$. nashi is closely allied to $T$. aureotinctum Forbes, a Recent species on this coast, which is quite variable in outline. Nost of the specimens of T. aureotinctum show two heavy spiral ribs on the whorls of the spire and on the base there are four fairly wide, deep grooves. The angulation between the base and the sides of the body whorl is less distinet on $T$. nashi; otherwise the two species resemble each other very closely.

Named in honor of Mrs. Louise Nash.

Dimensions.-Ileight of shell, $14 \mathrm{~mm}$. ; greatest width of body whorl, $16 \mathrm{~mm}$.

Occurrence.-Found in the Upper San Pablo Group east of the town of WValnut Creek, University of California locality 1947.

\section{LITTORINA PITTSBURGENSIS, n. sp.}

Plate 65, figure 22

Shell conical, thick; whorls four to five in number; sutures appressed. Body whorl rounding at base; anteriorly the sides of the whorls are slightly convex; posteriorly they are slightly concave, giving a collar-like effect next to the suture. Surface smooth except for lines of growth; mouth nearly round.

L. pittsburgensis, n. sp., is somewhat similar in outline to L. remondi Gabb found in the Lower San Pablo of the same region, but it lacks the angle at the base of body whorl and also the spiral ribbing which is seen on Litterina remondi. The sides of the body whorl of $L$. remondi are flatter than those of $L$. pittsburgensis.

Dimensions-Height, about $13 \mathrm{~mm}$; greatest width of body whorl, $10 \mathrm{~mm}$. 
Occurrence.- This species is found in the upper beds of the San Pablo Group in the region of Kirker Pass, University of California locality 1482. It is here associated with Cyrena californica Gabb and Trophon ponderosum Gabb.

\section{CREPIDULA PABLOENSIS, n. $\mathrm{sp}$. \\ Plate 70 , figures 1,2 , and 3}

Shell elevated, heavy; base broadly ovate to subcircular; upper surface broadly arched; apex nearly central, elevated considerably above the posterior edge of aperture. Sides of shell nearly vertical, the right side being slightly higher than the left. Deck concave similar to that of $C$. princeps Conrad. Surface seulptured by rather coarse radiating ribs, separated by narrow interspaces; surface also covered by fairly coarse concentric lines of growth.

This species somewhat resembles in outline $C$. adunca Sowerby, a Recent form, which also occurs in the San Pablo Group; it differs in the prominent radiating ribs, larger size, the concave anterior edge of the deck, and the beaks are not so hooked.

Occurrence.-In the Upper San Pablo Group to the southeast of the town of Walnut Creek, University of California locality 313.

\section{CALYPTRAEA DIABLOENSIS, n. sp.}

Plate 70, figure 9

Shell high, rather large and heavy for this genus; apex subacute and central; sutures obscurely appressed; surface covered by about 21 to 25 heavy, broad, rounded, slightly oblique longitudinal ribs with deep $\mathrm{V}$-shaped interspaces, the interspaces being much narrower than the tops of the ribs, the ribbing extending uninterruptedly from one whorl to the next.

This species resembles somewhat the specimen figured by Arnold as Trochita costellata Conrad (Bull. U. S. G. S. no. 309, p. 236, pl. XXXII). C. diablocnsis is a larger and higher form. The ribbing is more prominent, heavier and closer together.

C. diabloensis was listed by the writer in his paper the "Neocene Section at Kirker Pass on the North Side of Mount Diablo," Unirersity of Calif. Publ. Bull. Dept. Geol., vol. 7, no. 4, p. 54, as C. costellata Conrad. Further work and better material shows that the determination was wrong. 
Dimensions.-Maximum diameter, about $55 \mathrm{~mm}$.; maximum altitude, about $35 \mathrm{~mm}$.

Occurrence.-From the Lower San Pablo Group on the north side and the south side of Mount Diablo, University of California localities 102. 480, etc.

CALYPTRAEA MARTIYI, n, sp.

Plate 70 , figure $S$

Shell fairly large, coniform, somewhat variable as to height and symmetry; suture quite distinct, impressed. Surface covered by medium coarse, flat-topped, radiating ribs; on the body whorl there are between thirty-five and forty of these ribs, between which the interspaces are about as wide as the tops of the ribs.

This species differs from $C$. diabloensis, $n$. sp., in that the ribs are more numerons and are not so coarse and are wider apart. The ribbing is coarser than on $C$. filosa Gabb; also, the shell is considerably larger and the suture is more distinet. A comparison of $C$. martini with $C$. costellata Conrad, figured by Arnold, from the lower Niocene, shows that the ribs of the latter are less numerous, farther apart and are rounded instead of being flat-topped. C. radians Lamark, a Recent West Coast species, differs from C. martini, n. sp., in having finer radiating ribs, which also are not as flat-topped as in the latter, and the sutures are not so distinct.

Named in honor of Mr. Bruce Martin, formerly assistant eurator of palaeontology of the California Academy of Sciences, San Francisco.

Dimensions.-Naximum diameter of type, about $43 \mathrm{~mm}$.; maximum height, about $25 \mathrm{~mm}$.

Occurrence.-From the Upper San Pablo to the east of Walnut Creek, Contra Costa County, University of California locality 1945. Also from the uppermost fossiliferous beds in the Santa Margarita to the north of Coalinga, University of Califomia locality 2283.

\section{NATICA (EUSPIRA) DIABLOENSIS, n. sp. \\ Plate 68, figure 7}

Shell heavy, medium in size; spire fairly well elevated; number of whorls five. Body whorl regularly convex, a little more than twothirds the height of the shell. Sutures appressed; surface of shell smooth, except for somewhat irregular incremental lines of growth. 
Mouth semilunate with fairly heavy triangular callus in the posterior angle of the inner lip; umbilical opening rather narrow and elongate.

This species somewhat resembles $N$. lewisii Gould. a Recent form on the West Coast; it differs in that the spire is slightly more acute and it lacks the shallow, spiral groove, which is seen on $\Lambda$. lewisii just below the suture. The callus on the inner lip of $N$. diabloensis is heavier than on $N$. lewisii and the umbilical opening is longer and narrower.

It is very doubtful whether $N$. lewisii extends much below the Pleistocene. It is, however, found in nearly all the old California Miocene and Pliocene check-lists. There have been at least four or five species listed as $N$. lewisii.

Dimensions.-Height, $49 \mathrm{~mm}$; greatest width of body whorl, $35 \mathrm{~mm}$.

Occurrence.-In the Upper San Pablo, associated with Astrodapsis tumidus, Tivela gabbi, etc.; University of California locality 1947. Also in the upper Santa Margarita to the north of Coalinga.

\section{NATICA (EUSPIRA) KIRKENSIS, n. sp.}

Plate 69, figures 4 and 9

Shell heavy; base broad; apex acute; spire about half as high as the body whorl. Sutures strongly appressed, the appressed part of the lower whorl sometimes extending as much as half way up to the next suture. On many of the specimens the appressed part of the body whorl has been weathered away; the suture then is strongly depressed, giving a subtabulate effect to the whorl. Surface of shell smooth except for somewhat irregular lines of growth. Peristome semilunate. A heavy, ungrooved triangular callus on the inner lip. which is broader on the upper angle of the mouth, spreading out on the base of the whorl. Umbilicus large, open.

$N$. kirkensis differs from $N$. diabloensis, $\mathrm{n}$. sp., found in the Upper San Pablo in that the body whorl is broader in proportion to the height of the shell; the base is broader and latter; the sutures are more strongly appressed and the umbilical opening is much broader and more open.

Dimensions.-Type specimen : height, $36 \mathrm{~mm}$; greatest diameter of body whorl, about $33 \mathrm{~mm}$.

Occurrence.-University of California localities $100,183,463,752$. So far this species has not been found in the Upper San Pablo. It is common in the Lower San Pablo and the Scutella breweriana zone. 


\section{NATICA (NEVERITA) ARNOLDI, n. sp.}

Plate 68, figures 13 and 15

Shell heavy, ovate in longitudinal ontline; spire somewhat variable in height; apex acute. Whorls four to five; sutures strongly appressed; body whorl nearly three times as high as spire. Outer lip sharp; inner lip completely covered by a large elongate callus which is wider posteriorly than anteriorly. On the larger specimens the callus covers the umbilicus completely, on some of the smaller specimens the umbilicus is partially open. Surface smooth except for ineremental lines; base of body whorl narrow, slanting down obliquely to the umbilieus.

This species differs from $\lambda$. diabloensis, n. sp., which is found in the same horizon, in that the base is narrower. the mouth is more elongate; the sutures are more strongly appressed; the umbilicus is usually entirely covered by the elongate callus, while the umbilicus of $N$. diabloensis is entirely open; the spire is slightly higher and the body whorl is not so ventricose.

Dimensions.-IIeight, $39 \mathrm{~mm}$.; greatest width of body whorl, about $28 \mathrm{~mm}$; height of body whorl, $29 \mathrm{~mm}$.

Occurrence.-Upper San Pablo Group, University of California localities 505, 1270 and 1229 .

\section{NATICA (NEVERITA) PABLOENSIS, n. sp.}

Plate 68, figures 12 and 14

Shell large, globular, thick, heavy. Whorls three; spire low, inconspicuous, so mueh so that the top of the shell is very broadly rounded or flattened. Sutures very strongly appressed. Body whorl large with sides Hattened, tending to form an obscure shoulder on the upper part of the whorl. Surface covered by fairly heavy lines of growth. Aperture semi-lunar; outer lip thin; inner lip and umbilicus covered by a broad, flat, faintly grooved callus. Umbilicus completely covered by callus.

The writer has examined over a dozen specimens of this species on which the callus was very well preserved; only on two of these could the anterior groove be seen and on those it showed only very faintly.

X. pabloensis is very similar to $N$. ocoyana Conrad, a species very common in the Lower Neocene of the southern part of the state. Both of these species are closely allied to $N$. recluziana Petit, a Recent 
species on this coast. They differ from the latter in having the flattened sides with the obscure shoulder on the upper part of the body whorl. $N$. pabloensis differs from $N$. ocoyana in having a lower spire, the top of the shell is broader, sloping down less rapidly to the obseure shoulder.

Dimensions.--Type specimen (pl. 68, fig. 12): height, about 37 $\mathrm{mm}$; greatest width, about $42 \mathrm{~mm}$; length of aperture, $34 \mathrm{~mm}$.; width of aperture, $17 \mathrm{~mm}$.

Occurrence.-In the Upper and Lower San Pablo Group, University of California localities $231,38,1227$, etc.; also, in the Seutella breweriana zone.

\section{BITTIUM? PABLOENSIS, n. sp.}

Plate 65, figure 10

Shell medium in size; spire high, acute; whorls six or seven. On the upper edge of each whorl is a rounded, slightly raised ridge or rim which gives to the shell a tabulated effect; sides of whorls flat below the rim; sutures depressed. Surface covered with regular, medium fine, revolving ribs with interspaces about as wide as the ribs; on the body whorl there are ten or twelve of these revolving ribs, on the whorls of the spire the ribbing is obscure; outer lip sharp. Inner lip smooth; aperture oval, only slightly emarginated anteriorly.

Dimensions.--Height, about $16 \mathrm{~mm}$.; grentest width of body whorl. $8 \mathrm{~mm}$.

Occurrence.-So far only two specimens of this species have been found; these came from near the top of the San Pablo Group on San Pablo Bay, associated with Cyrena californica Gabb, Cerithium rodeoensis, n. sp., Iytilus perrini, n. sp., Mya dickersoni, n. sp., University of California localities 1617 and 1618 .

\section{BITTIUM TRAMPASENSIS, n. sp.}

Plate 65, figures 3 and 5

Shell small: number of whorls, seven or eight, or possibly nine. Sides of whorls flat, sutures impressed. Surface sculptured by about twenty medium fine longitudinal ribs, the interspaces between whieh are about as wide as the tops of the ribs. Surface also covered by medium fine spiral nodose ribbing, the nodes being at the point of junction with the longitudinal ribbing. On the body whorl there are six of these spiral ribs; the anterior rib is partly on the base. The 
interspaces between these ribs are equal and about as wide as the tops of the ribs; posteriorly there is a small sutural unnodose riblet. On the whorls of the spire there are four of the heavy spiral ribs each with an obscure, sutural riblet posteriorly. Base of body whorl smooth, slightly convex, Peristome subquadrate in outline, faintly emarginated anteriorly. Inner lip inerusted and slightly flattened.

Dimension.-Height, about $8 \mathrm{~mm}$.

Occurrence,-Upper San Pablo. University of California locality 118.

\section{CERITHIOPSIS TURNERI, n. sp.}

Plate 65, figures 1 and I

Spire high, elongate, conical, with ten or eleven whorls; sides of whorls flat. Sutures deeply impressed. Body whorl angulate at junction of sides with base. Seulpturing of nucular whorl not preserved. Whorls of spire with four fairly prominent, revolving ribs with a riblet on the lower part of each whorl just at the suture; interspaces between the ribs about equal in width to the ribs. Body whorl with six revolving ribs, the two anterior ribs being the smaller and situated at the angle between the base of the whorl and the sides. Surface also sculptured by eighteen or nineteen longitudinal ribs, which form prominent nodes at the junction with the revolving ribs; base of body whorl smooth, quite flat, slightly convex anteriorly. Nouth subovate, rather strongly emarginated; outer lip sharp; columella short, smooth, slightly twisted.

Named in honor of H. W. Turner, one of the first to make a systematic study of the geology of the Mount Diablo region.

Dimensions.-Type specimen : height, about $15 \mathrm{~mm}$.; greatest width of body whorl, $4 \mathrm{~mm}$.

Occurrence.-In the Lower San Pablo group at Kirker Pass, University of California locality 100.

\section{CERITHIOPSIS BOLINGERENSIS, n. sp.}

Plate 65, figure 25

Shell small; number of whorls, seven or eight, the sides of which are only slightly convex with impressed sutures. Surface sculptured by nineteen or twenty medium fine, longitudinal ribs, the interspaces between which are about as wide as the tops of the ribs. Surface also sculptured by medium fine spiral nodose ribbing. On the body 
whorl there are seven of these spiral ribs, the interspaces between which are unequal. Beginning at the suture, the first two interspaces between the spiral ribbing are about as wide as the tops of the ribs, the next two interspaces are narrower than the tops of the ribs, the next interspace is of the wide type and the one anterior to it is of the narrow type. This gives the distribution of the ribs on the body whorl as follows: Commeneing at the suture, there are two spiral ribs separated by a wide interspace; these may be considered as a pair; the posterior of the two is not as heavy as the other. Anterior to this first pair is a group of three spiral ribs, separated by narrow interspaces, and last a pair of less nodose spiral ribs, separated from the group of three by a wide interspace, and from each other by the narrower type of interspace. This last pair of ribs is situated on the angle between the side of the body whorl and the base, the anterior rib being partly on the base.

The spiral ribbing on the whorls of the spire is the same as on the body whorl, except that the anterior pair of ribs is lacking; thus beginning at the Iower suture there is a group of three spiral ribs separated by narrow interspaces; posterior to this is the pair separated by wider interspaces, the rib next to the suture not being as heavy as the other.

Base of body whorl smooth, nearly flat. Peristome subquadrate; columella with one distinct plication. (There were probably at least two plications). The anterior end of the columella of the type is broken. Inner lip not incrusted.

Dimensions.-Height, about $8 \mathrm{~mm}$.

Occurrence.-Upper San Pablo of Las Trampas Ridge, University of California locality 1182.

\section{CERITHIUM RODEOENSIS, n. sp.}

Plate 69, figures 1 and 10

Shell medium in size, turreted; apex acute; number of whorls eight or nine. Sides of whorls convex. Sutures depressed. Surface of whorls sculptured by narrow, prominent spiral ribbing with interspaces usually wider than the tops of the ribs; whorls of spire with five to six of these revolving ribs; on the body whorl there are about fifteen of the revolving ribs, which are coarser posteriorly near the suture while anteriorly on the base they become finer and eloser together. Whorls also sculptured by thirteen or fourteen variable 
longitudinal ribs which tend to become obsolete on the body whorl. and sometimes almost, if not entirely, obsolete on the anterior whorls of the spire. Base of body whorl rounded; outer lip sharp; inner lip smooth; mouth ovate with a fairly strong emargination anteriorly.

Dimensions.-Type specimen : height, about $19 \mathrm{~mm}$; greatest width of body whorl, about $7 \mathrm{~mm}$.

Occurrence-A very common species in the Upper San Pablo Group, University of California loealities 1617, 1207, 1081, ete.

\section{BURSA TRAMPASENSIS, n, sp.}

Plate $6 \pi$, figure 3

Shell large, solid with six or seven regularly convex whorls, on each of which there are two fairly prominent rope-like, discontinuous varices. Surface of shell sculptured by fairly heavy, rounded, nodose longitudinal ribs, the interspaces between which are somewhat wider than the ribs. On the body whorl between the two varices, there are sixteen of these longitudinal ribs. Surface also sculptured by medium fine, revolving ribs, which on the type specimen are rather indistinct. Sutures deeply impressed, the whorls being quite strongly and nodosely carinate next to the suture; this carinate effect is produced more strongly because of the fact that on each whorl a fairly distinet groove or sulcus encircles it just below the suture. Mouth and canal unknown.

Dimonsions.-Greatest width of body whorl about $4 \pm \mathrm{mm}$; height of spire, about $25 \mathrm{~mm}$.

Occurrence.-A single specimen of this species was found in beds of the Lower San Pablo Group on Las Trampas Ridge, University of California locality 1251.

COLUMBELLA (ASTYRIS) KIRKENSIS, n. sp.

Plate 69, figure 8

Shell small, narrow; spire high; whorls six or seven; sutures distinctly impressed. Whorls of spire very slightly convex. Just below the suture on the body whorl there is sometimes a distinet shoulder similar to that seen on C. gausapata var. carinata Hinds, a Recent West Coast form. Surface smooth except for a few spiral lines on anterior part of body whorl. Outer lip sharp ; interior of outer lip not exposed; inner lip smooth, not inerusted, with small oblique groove on columella. 
This species was listed by the writer in his paper on the Neocene of Kirker Pass as $C$. richthofeni Gabb, but better specimens show that it should be classed as a new species; it differs from $C$. richthofeni in having a longer and more slender canal; the body whorl is less tumid toward the base; the inner lip is not incruster as on $C$. richthofeni; the columella of the latter lacks the oblique groove seen on $C$. kirkensis.

Dimensions.-Height about $10 \mathrm{~mm}$. ; greatest width of body whorl, $4 \mathrm{~mm}$.

Occurrence.-In the Lower San Pablo Group near Kirker Pass, University of California localities 1891 and 102.

\section{NASSA PABLOENSIS, n. sp.}

Plate 65, figures 8 and 9

Shell fairly heary, medium in size, slender. Number of whorls to spire seven. Sutures deeply depressed; whorls moderately convex. Surface sculptured by sixteen to eighteen medium coarse longitudinal ribs, with interspaces about equal to the width of the ribs. Surface also covered by revolving ribs which are about as heavy and have about the same width of interspaces as the longitudinal ribbing; on the body whorl there are nine revolving ribs; on the whorls of the spire there are four to five; on the type specimen the junction of these two sets of ribbing gives a nodose effect similar to that seen on $\mathrm{N}$. californica Conrad, a Recent species on the Pacific Coast; on other specimens this character is not so prominent. On the outer lip there is a fairly prominent rope-like varix; the back part of the type specimen is not exposed but on other specimens a second varix is seen on the posterior part of the body whorl, and a faint varix may also be seen on the first whorl of the spire. Immer lip incrusted; columella with four fairly prominent plications or ridges, a continuation of the revolving ribbing of the body whorl. Canal short and reflexed, separated posteriorly from the body whorl by a fairly deep sinus.

This species is very similar in outline to $\mathrm{N}$. mendica Gould, a Recent species on this coast. It differs in that the longitudinal ribs are eloser together and more numerous, and in the presence of the rope-like varices.

$N$. pabloensis differs from $N$. californica in the presence of the varices; the shell is more slender; the concentric and longitudinal ribs are closer together and differ in number. 
$N$. tegula Reeve, a Recent species on this eoast, develops a varix on the outer lip but in other respects it differs very radically from $N$. pabloensis.

Dimensions.-Type specimen: height, $16 \mathrm{~mm}$; greatest width of body whorl, $7 \mathrm{~mm}$; height of body whorl measured just posterior to outer lip, $7 \mathrm{~mm}$.

Occurrence.-From the Upper San Pablo Group, University of California localities 1947 and 1948, south side of Mount Diablo Anticline to the east of Walnut Creek, and locality 1617, San Pablo Bay section about one mile east of Union Oil Works.

\section{HEMIFUSUS DALLI, n, sp.}

Plate 68, figure 10

Shell small, fusiform; spire moderate in height; apex acute; sutures obscurely impressed; whorls five, subangulate; surface above the angulation subtabulate; surface of whorls covered by medium fine, rather numerous, rounded longitudinal ribs; on the body whorl there are twelve or thirteen of these ribs, which gradually disappear toward the anterior part of the whorl; the longitudinal ribbing is quite prominent on the anterior whorl of the spire but is very faint on the other whorls; surface, also, sculptured by fairly coarse, rounded, spiral ribbing with interspaces slightly narrower than the ribs; where the spiral ribbing passes over the longitudinal ribbing a node is formed, thus the upper part of the body whorl and the first whorl of the spire are quite nodose; outer lip sharp, thin ; inner lip smooth, not incrusted; canal short and straight, open and rather deep; umbilicus imperforate.

Dimensions.-Length, $10 \mathrm{~mm}$. ; length of body whorl, $6 \mathrm{~mm}$; greatest width of body whorl, $5 \mathrm{~mm}$.

Occurrence.-A single speeimen has been found in the Upper San Pablo Group on San Pablo Bay, University of California locality 1631; associated with Cyrina califomica Gabb, Macoma pabloensis, n. sp., Iya dickersoni, n.sp., Mytilus perrini, n.sp., and Bittium pabloensis, n. sp.

CHRYSODOMUS BUWALDI, n. sp.

Plate 68, figure 4

Shell medium in size, fusiform; body whorl long. Spire moderate in height; whorls regularly convex. Number of whorls five. Sutures deeply impressed. Surface of whorls sculptured by coarse, broadly 
rounded spiral ribbing with moderately deep interspaces which are nearly as wide as the tops of the ribs. On the body whorl there are about seven of these coarse spiral ribs, the ribbing being obsolete on the canal. On each whorl of the spire there are three of the revolving ribs. Outer lip sharp; inner lip smooth and rounding; canal medium long, straight and narrow.

Dimensions.-Height, $25 \mathrm{~mm}$; height of body whorl, $18 \mathrm{~mm}$; greatest width of body whorl, $13 \mathrm{~mm}$.

Occurrence.-The writer so far has seen only one specimen of this species; this was found by Dr. John Buwalda (after whom it is named) to the southeast of the town of Walnut Creek in the Upper San Pablo Group, University of California locality 1263.

\section{CHRYSODONUS CIERBOENSIS, n. sp.}

Plate 68 , figure 1

Shell large, thick, spire high, acute; whorls regularly and rather strongly convex with deeply depressed sutures; number of whorls six or seven; surface of whorls sculptured by coarse, flat-topped, revolving ribbing, a wide rib alternating with a narrower rib, the interspaces between which are about equal to the width of the minor rib. Toward the anterior end of the body whorl the two sets of ribbing become nearly equal. On the whorls of the spire there are usually four of the major revolving ribs, sometimes five; on the body whorl there are eight or nine of the major revolving ribs. Interspaces between revolving ribs narrower than the tops of the major ribs; canal moderate in length; outer lip sharp, crenulated internally; inner lip smooth.

Occurrence.-This species is a very common form from the Lower San Pablo Group, University of California localities 409 and 1532.

\section{CHRYSODOMIUS DIABLOENSIS, n. $\mathrm{sp}$.}

Plate 68 , figure 3

Shell fusiform; spire high, with four to five whorls; apex acute. Body whorl a little less than two-thirds the height of the shell. Sutures impressed. Surface sculptured by fine, sharp, narrow, revolving ribs. On the body whorl there are nineteen of these ribs, while on each whorl of the spire there are nine or ten. These ribs tend to go in pairs, every other interspace usually being wider than the ones next to it, the wider interspaces being nearly twice as broad as the tops of 
the ribs. Besides the revolving ribbing there is a finer longitudinal series of ribs, the width of the interspaces of which is about equal to the interspaces of the revolving ribs, thus marking off the surface into little squares; this longitudinal ribbing becomes obsolete on the anterior end of the body whorl. Nouth elongate-ovate; outer lip sharp; inner lip smooth; eanal short and straight.

Dimensions.-Height, about $27 \mathrm{~mm}$; maximum width of body whorl, $13 \mathrm{~mm}$; height of body whorl, $16 \mathrm{~mm}$.

Occurrence.--In the Upper San Pablo Group to the southeast of Walnut Creek, Contra Costa County, Calif., University of California locality 1263.

\section{CHRYSODOMUS PABLOENSIS, n. sp.}

Plate 67 , figure 8

Shell heavy, rather large; whorls strongly and regularly convex. Body whorl nearly two-thirds the height of the shell. Whorls five or six. Sutures appressed. Surface sculptured by heavy, flat-topped spiral ribs, alternating irregularly with a narrower and finer spiral ribbing; interspaces between the major spiral ribs are usually about as widle as the tops of the larger ribs. On the body whorl there are usually eleven or twelve of the major revolving ribs, and an equal number of the interribs; anteriorly on the body whorl of the larger specimens the interribs become almost if not entirely as prominent as the major ribs. On the whorls of the spire there are eight fairly heavy spiral ribs; in the interspaces of some of these there is an interrib. Posteriorly the sutural rib on each whorl is heavier and more prominent than the others, partially concealing the suture and giving a collar-like effect to the whorl. Outer lip sharp; inner lip smooth; umbilicus subperforate; eanal short.

C. pablomsis appears to be elosely allied to C. portalensis Arnold, the main differences being that on the former the spiral ribbing ap. pears to be somewhat heavier and it lacks the longitudinal ribs seen on the whorls of the spire of the latter; otherwise the two species are remarkably similar.

Chrysodomus pablocnsis is somewhat similar in seulpturing to $C$. cicrboensis, n. sp., which is also found in the Lower San Pablo Group: it differs in being more rentricose; the canal is not so long, and it has the collar-like rib next to the suture not seen on $C$, cicrboensis.

Dimensions.-Type specimen : height, about $65 \mathrm{~mm}$; greatest width of body whorl, $38 \mathrm{~mm}$. 
Occurrence.-Found on San Pablo Bay in Scutella gabbii zone, University of California localities 409 and 511, also at many other loealities, Mount Diablo, Las Trampas, ete.

\section{SIPHONALIA DANVILLENSIS, n. sp.}

Plate 67, figure 6

Shell fusiform; body whorl tumid; spire high; sutures impressed; whorls angulated well above the middle and tabulate between the angulation and suture; the angulation is somewhat inconspicuous on the body whorl but prominent on the first whorl of the spire. Surface of whorls sculptured by seven prominent transverse flute-like ridges; on the body whorl these ridges are heavier toward the upper part of the whorl, disappearing anteriorly. Shell also spirally sculptured by fairly coarse, somewhat irregular ribbing, the interspaces between which are very narrow. On the whorl of the spire there are ten of these spiral ribs, three of which are on the tabulate area; on the body whorl there are thirteen spiral ribs, the ribbing being obsolete on the tabulate area and on the canal. Onter lip sharp and thin; inner lip smooth, incrusted; canal medium in length, very slightly turned back; umbilicus subperforate.

Dimensions.-Height of body whorl, $25 \mathrm{~mm}$; greatest width of body whorl, $22 \mathrm{~mm}$.

Occurrence.-From the San Pablo Group to the south of Danville, University of California locality 323. The writer has only one specimen of this species in his possession at the present time, and the upper whorls of the spire of this have been broken off.

\section{TROPHON CARISAENSIS Amlerson}

Plate 66, figures 1 and 2

Chorus carisaensis Anderson, Calif. Acad. Sei., 3rd series, rol. II, no. 2, T. 206, figs. 90-91.

Trophon carisaensis Anderson Arnold, Bull. U. S. G. S. no. 396, pl. X, fig. 4; Bull. 398, pl. XXXII, ..g. 4.

Shell rather large and thick, strongly spinose and oblique; spire moderately high, sloping above; body whorl narrowing rapidly below; aperture large, triangular, bearing a stont tooth on the outer lip near the upper end of the canal; canal narrow, short and strongly recurved; columella crusted and strongly recurved; surface marked only by strong lines of growth. There are eight strong spines on the angles of each whorl, excarnted in front and convex behind.

This species is quite variable. The characteristies that seem to be the most constant are the heavy spines which stand out nearly at right 
angles to the sides of the whorls, and the deep fold on the body whorl between the anterior end and the spines; the whorls of the spire on some specimens show a distinet spiral ribbing. The characters that are the most variable are the prominency of the spines, the slope between the spines and the suture and the height of the spire.

Occurrence.-Very common in the Upper San Pablo Group of San Pablo Bay, north of Mount Diablo, Los Trampas and Rocky Ridges.

\section{TROPHON GRACILIS Perry rar. PABLOENSIS, n. var.}

Plate 66, figures 6 and 7

Shell medium-sized; spire rather high; apex acute; number of whorls to spire five or six; body whorl large; sutures obscurely appressed. Whorls angulated, with the narrow surface above the angulation sloping up gently to the suture. Surface of shell crossed by ten or eleven prominent lamella-like varices which are flexed forward and produced on the angle into upright, fairly prominent spines; on the upper whorls of the spire the varices hecome prominent ridges. Spiral ribbing lacking; outer lip sharp; inner lip smooth and incrusted; eanal broken on all the specimens that the writer so far has obtained.

This variety differs from the speeies $T$. gracilis Perry in being a heavier and larger shell; the tabulated effect above the angle is not so marked; the suture is appressed while on $T$. gracilis it is depressed; the lamella-like varices on the body whorl do not extend as far anteriorly as on $T$. gracilis and the spines at the line of angulation are more prominent.

Occurrence.-Found in the Lower San Pablo Group on San Pablo Bay, University of California locality 409.

\section{TROPHON DICKERSONI, n. sP.}

Plate 68, figures 5 and 6

Shell medium in size; spire one-third the height of the body whorl; sutures impressed; whorls regularly convex, except for a small tabulated area just below the suture; number of whorls five or six. Surface covered by eight or nine lamelliform varices; on the body whorl the varices just below the suture and on the edge of the narrow tabulated area form fairly prominent, broad, reflected spines. Surface of shell also covered by two sets of alteruating rounded revolving ribs, one set being heavier than the other; the interspaces between these ribs 
are narrower than the ribs. On the body whorl there are about twenty to twenty-one of these ribs. On the whorls of the spire there are only three or four. Outer lip thin, smooth internally; inner lip incrusted. Peristome elongate-ovate. Canal open, straight, fairly long. Umbilicus subperforate.

Named in honor of Dr. R. E. Dickerson, assistant eurator of palaeontology of the California Academy of Sciences, San Francisco.

Dimensions.-Type specimen: height, $20 \mathrm{~mm}$; greatest diameter of body whorl, $11 \mathrm{~mm}$; height of body whorl, $15 \mathrm{~mm}$.

Occurrence,-Lower San Pablo on San Pablo Bay, University of California locality 410.

\section{TROPHON LAWSONI, n. sp.}

Plate 67 , fgures 10 and 11

Shell large, robust, thick; spire moderate in height, with four to five whorls, the last two or three being small; apex acute; body whorl large. Surface of whorls sculptured by about eight or nine prominent, thick, lamella-like varices; on some specimens the varices are angulated but never spinose; whorls angulated, with the surface sloping up gently from the angle to the suture; sutures obscurely appressed; no revolving ribbing apparent. Outer lip thick; inner lip smooth. Canal short, narrow, deep and strongly recurved.

Named in honor of Professor A. C. Lawson, Professor of Geolog: at the University of California.

Dimensions.-Type specimen: maximum altitude, about $93 \mathrm{~mm}$.; maximum width of body whorl, $64 \mathrm{~mm}$.

Occurrence.-In the Upper San Pablo Group on San Pablo Bay, University of California locality 1611, and on the south sicle of Mount Diablo, University of California locality 1499.

\section{TROPHON PONDEROSUN Gabb}

Plate 66, figures 3 and 4

Trophon ponderosum Gabb, Palaeontology of California, vol. 2, p. 2, pl. 1 , fig. 3.

Shell moderately robust, thick; spire subelevated; whorls fire; angulated in the middle, sloping above; suture irregularly impressed; surface marked by eight or nine blunt varices, prominent and acute on the angle of the whorl, and commonly becoming more or less obsolete above and below; in the upper whorls the varices are replaced by mere elevated ribs, which become smaller until in the first three volutions they barely exist as undulations. Aperture broad; eanal open, short, slightly recurved; columelar lip heavily incrusted: outer lip entire, subacute. Umbilicus well marked, but closed. 
Localities and Positions.-From the Pliocene of Kirker Pass; also from the Miocene at Walnut Creek, Contra Costa County, and Griswold's, Monterey County, on the road to New Idria.

T. ponderosum differs from $T$. carisaensis in that the spines are less prominent, more numerous and do not stand out at right angles to the surface of the shell but are turned upward; on some specimens the spines become nearly obsolete; the canal is not so long; the spiral ribbing is usually present on the body whorl as well as on the whorls of the spire. It lacks the sinus or groove which is so marked on $T$. carisaensis and which is situated about half way between the spinose shoulder of the body whorl and the anterior end of the canal.

Occurrence.-On the north side of Mount Diablo, T. ponderosum and $T$. carisacnsis Anderson are found in the same section, $T$. ponderosum being found at the top of the section while $T$. carisaensis is found about two hundred feet below associated with a different fauna. T. ponderosum is also found to the southeast of the town of Walnut Creek, where it is found in nearly the same horizon as $T$. carisaensis.

TROPHON PONDEROSUM Gabb var. PABLOENSIS, n. var.

Plate 66, figure 5

Shell large; spire low with three or four whorls; body whorl very rentricose; sutures obseurely impressed; surface of body whorl sculptured by about twelve thin, lamella-like varices, which are more prominent on the tops of the whorls, becoming quickly obscure anteriorly; whorls unangulated; revolving ribbing not evident; mouth opening wide, semilunar; outer lip sharp, slightly reflexed anteriorly; inner lip enerusted; canal short, narrow and slightly twisted; umbilical sear long and subperforate.

Only one specimen of $T$. ponderosum var. pabloensis, n. var., has so far been found. More collecting may show that it should not be separated as a variety; on the other hand, it may prove to be a distinct form worthy of being classed as a species. It differs from $T$. ponderosum in that it is not spinose; the whorls are not angulated, and the spire is not so high.

Dimensions.-Length of shell, about $61 \mathrm{~mm}$.; length of body whorl, $49 \mathrm{~mm}$; greatest width of body whorl, $49 \mathrm{~mm}$.

Occurrence.-In the Upper San Pablo Group to the southeast of the tomn of Walnut Creek, University of California locality 140. 


\section{MIUREX (OCINEBRA) DALLI, n. sp.}

Plate 67 , figures 4 and 9

Shell medium in size, fusiform, fairly heavy; apex acute. Whorls regularly convex; number of whorls seven; spire a little over onehalf the height of the body whorl. Shell sculptured by medium coarse, rounded, revolving ribs, the interspaces between which are much narrower than the tops of the ribs; on the body whorl there are about twenty-two of these revolving ribs, on the whorls of the spire there are five or six. On some specimens, available for study, every other spiral rib stands out more prominently, thus showing an alternation of a rib and an interrib. This is true of the specimens from locality 1182 to the south of Walnut Creek, Contra Costa County. Surface of shell also sculptured by eight or nine prominent, rounded, longitudinal ribs; these longitudinal ribs show considerable variation in prominency and tend to be split or grooved. Mouth ovate; outer lip sometimes thickened externally, dentate internally; inner lip heavily encrusted; canal medium in length, straight and deep; on some specimens it is entirely closed, on others only partially; columella subperforate.

II. dalli differs from $M$. selbyensis, n. sp., a species found in the Lower San Pablo, in that it is a more slender shell; the spire is higher, and the canal longer, and the spiral ribbing does not become obsolete next to the suture.

Named in honor of Dr. W. H. Dall of the Smithsonian Institute.

Dimensions.-Type specimen: height, $23 \mathrm{~mm}$; height of body whorl, $4 \mathrm{~mm}$. ; greatest width of body whorl, $12 \mathrm{~mm}$.

Occurrence.-This form so far has been found only in the Upper San Pablo. It is found associated with Astrodapsis tumidus Rémond, Tivela gabbi, n. sp., Trophon carisaensis Anderson, ete. University of California localities $1620,1881,521$, ete.

\section{MIUREX (OCINEBRA) PACKARDI, n. sp.}

Plate 69, figures 2 and 11

Shell elongate-oval, heavy, rather large for this genus. Spire high; apex acute; sutures deeply depressed. Whorls strongly and regularly convex; body whorl a little less than two-thirds the height of the spire. Surface covered by rather coarse, broadly rounded, revolving ribs with interspaces slightly wider than the ribs; in each interspace there is a narrow, low riblet; on each of the first two whorls 
of the spire there are four of the major revolving ribs, on the body whorl there are eight or nine of the major ribs. On some of the specimens examined there are very $\pi^{2}$ ell-defined varices; sometimes there is a varix on the outer lip, sometimes, one or two varices are found posterior to this; on none of the specimens examined do the varices extend up on the whorls of the spire. Onter lip thickened internally, on which are rounded to elongate denticulations. Aperture elongate, semilunar; inner lip heavily encrusted; canal short, straight, narrow and deep; umbilicus subperforate.

Dimensions.-Type specimen : height, about $31 \mathrm{~mm}$; height of body whorl, $32 \mathrm{~mm}$. ; maximum width of body whorl, $27 \mathrm{~mm}$.

Occurrence.--In Upper and Lower San Pablo Group, University of California localities $409,1492,363$, etc.

\section{MUREX (OCINEBRA) SELBYENSIS, n. sp.}

Plate $6 \pi$, figures 2,5 , and 7

Shell rather small to medium in size, heavy, subfusiform; apex acute; number of whorls five or six, all strongly and regularly convex. Spire about half the height of the body whorl; sutures slightly appressed. Surface of shell sculptured by medium revolving ribs, the interspaces between which are usually wider than the ribs; in each interspace there is a riblet. Below the suture for a short distance the revolving ribbing tends to be obsolete; this is quite noticeable on the body whorl and on the lower whorl of the spire. On each whorl of the spire there are three, sometimes four, of the major revolving ribs, the inter-ribs being very faint or obsolete altogether; on the body whorl there are eleven or twelve of the major ribs, the inter-ribs being rather prominent; on the canal the major ribbing and the interribbing are almost indistinguishable. Surface of shell also covered by eight or nine fairly heary, longitudinal ribs; these are narrower and more distinct on the whorls of the spire than on the body whorl; on the body whorl these longitudinal ribs are usually rather broad, being prominent on some specimens, while on others they become almost obsolete; on some specimens the longitudinal ribs are grooved or split; this irregularity of the ribbing appears to be for the most part confined to the body whorl. Peristome broadly ovate; outer lip sonetimes thickened, dentate internally; inner lip strongly incrusted. Canal short, straight, very narrow to closed. Columella subperforate. 
This species resembles in outline Hurex (Ocinebra) lurida var. aspera Baird and in a former paper was listed as such by the writer ("The Neocene Section of Kirker Pass, Univ. of Calif. Publ. Bull. Dept. Geol., vol. 7, no. 4, pp. 17-60, 1912). It differs from that species in the eharacter of the revolving ribbing. On $\mathcal{H}$. lurida var. aspera the revolving ribbing is not obsolete just below the sutures, as in the case of $\boldsymbol{U}$. selbyensis. Also the number of revolving ribs is greater on the former than on the latter. The canal on the latter is more slender and a little longer than that on the former.

Dimensions.-Type specimen: height, $35 \mathrm{~mm}$. ; greatest diameter of body whorl, $23 \mathrm{~mm}$.

Occurrence.-Lower San Pablo Group, associated with Astrodapsis tumidus, subsp. cierboensis, Chrysodomus pabloensis, n. sp., Tivela diabloensis, n. sp., ete., University of California localities $102,409,410$, 525 , etc.

\section{CANCELLARIA PABLOENSIS, n. sp.}

Plate 68, figures 9 and 11

Shell ovate, thick; body whorl large; spire moderately low. Number of whorls to spire three or four; suture appressed; body whorl with fifteen or sixteen pointed nodes a little below the suture; this gives the whorl the appearance of being angulated or obscurely tabulated; whorls of spire not nodose. Surface of shell seulptured by medium fine revolving ribs, the interspaces between which are much narrower than the tops of the ribs. On the body whorl there are about thirty of the revolving ribs, while on the whorls of the spire there are only three or four. Canal short, very slightly twisted; outer lip sharp; inner lip callused. Columella with two fairly strong plications.

Dimensions.-Type specimen : height, about $34 \mathrm{~mm}$; height of body whorl, about $29 \mathrm{~mm}$. ; maximum width of body whorl, $27 \mathrm{~mm}$.

Occurrence-The type specimen was found in the San Pablo Group of Napa County, west of Will's ranch, Carneros Creek, by Mr. S. H. Gester and Mr. Reginald Stoner. Here it was associated with Tivela gabbi, n. sp., Natica amoldi, n. sp., and Mulinia densata Conrad, also found on the south side of Mount Diablo and on Rocky Ridge to the south of Walnut Creek. Both of these last localities are in the Upper San Pablo, University of California localities 480 and 1942; here the species is associated with the same fauna as in Napa County. 


\section{TURRIS KIIKENSIS, n. sp.}

Plate 69 , figures 5,6 , and 7

Shell small, elongate-ovate. Number of whorls five or six, which are regularly convex, with obscure appressed sutures and acute apex. Surface of shell sculptured by coarse, nodose, revolving ribs, between which are finer and less nodose riblets. On each of the major ribs there are about twenty rounded nodes; the nodes of the different ribs are in line giving the shell the appearance of being longitudinally ribbed. The distribution of the revolving ribs and riblets is as follows: Beginning at the suture on the body whorl there are two nodose indistinct ribs below which are two of the finer unnodose riblets, the anterior riblet being the heavier; anterior to this are two nodose ribs with one fine indistinct unnodose riblet between. Between the last two nodose ribs just mentioned and the anterior end of the canal there are five of the major ribs between each of which excepting the last anterior two, there are two riblets, in each case the anterior of the riblets is heavier and shows a tendency to be nodose.

On some specimens toward the anterior end of the body whorl the heavier of the two riblets seen between each of the major ribs becomes as prominent as the major ribbing itself, the nodose eharacter of the ribs disappearing. Whorls of spire with three of the heavier nodose revolving ribs; anteriorly at the suture are two of the riblets, the heavier type of riblet being in front; above these riblets are two of the nodnse ribs which are very close together with a faint indication of an interrib between; posteriorly this is again followed by two riblets the anterior one being the coarser; above these is a nodose rib between which and the suture is one of the coarser riblets. Posterior sinus on specimens figured obseure; outer lip sharp; inner lip smooth, incrusted; canal short and straight ; umbilicus subperforate.

Dimensions.-Type specimen : height, about $11 \mathrm{~mm}$; greatest width of body whorls, $5 \mathrm{~mm}$.

Occurrence.-In the Lower Division of the San Pablo Group, from the region of Kirker Pass to the north of Mount Diablo, University of California localities 102 and 406 . 


\section{DESCRIPTION OF LOCALITIES}

38. SE 1/4 Sec. 1, T. 2 S, R. 2 W, M. D. B. and M. Eleration, about 1100 feet.

39. In small gulch near west edge of SE 1/4 Sec. 1, T. $2 \mathrm{~S}, \mathrm{R} .2 \mathrm{~W}, \mathrm{M} . \mathrm{D} . \mathrm{B}$. and M.

41. South side of large gully in SW $1 / 1 \mathrm{NW} 1 / 4$ Sec. 7, T. $2 \mathrm{~S}, \mathrm{R} .1 \mathrm{TV}, \mathrm{M} . \mathrm{D}$. B. and M.

59. Just below "Pinole Tuff," NW corner SW 1/4 NW 1/t See. 30, T. 2 N, R. 1 E, M. D. B. and M.

60. South side of 651 -foot hill about 50 feet above bottom of gulch near east edge of NW $1 / 4$ SE $1 / 4$ Sec. 30 , T. 2 N, R. 1 E, M. D. B. and M.

62. In gulch on north side of 902 -foot hill; elevation about 550 feet; near east edge of NE $1 / 4$ SIV $1 / 4$ Sec. 34, T. 2 N, R. 1 E, MI. D. B. and M.

100. In basal beds of San Pablo Group; elevation about 500 feet; a little to west of middle of NW $1 / 4$ SW $1 / 4$ Sec. 30, T. 2 N, R. 1 E, M. D. B. and $M$.

102. In saddle below 594-foot hill just east of Kirker Creek, NE corner of SW $1 / 4$ SW $1 / 4$ See. 29, T. 2 N, R. 1 E, M. D. B. and M.

104. Southeast side of prominent hill at elevation of about 950 feet, near east edge of NW 1/4 NW 1/4 Sec. 9, T. 1 S, R. 1 W, M. D. B. and M.

115. Southeast side of prominent hill at elevation of about 1000 feet, near center of NW 1/4 NW 1/4 Sec, 9, T. 1 S, R. 1 W, M. D. B. and M.

120. On first prominent ridge to southwest of Shell Ridge on highest point just west of where creek cuts through ridge; about $21 \% \mathrm{~m}$ miles southeast of the center of the town of Walnut Creek and about $11 / 1$ miles west of east edge of Concord quadrangle.

122. About 21/2 miles southeast of the center of the town of WaInut Creek on first ridge southwest of Shell Ridge, where crejk breaks through ridge, stratigraphically below loc, 120 and on north side of same hill, Concord Topographic sheet, U. S. G. S.

130. Near east edge of SW $1 / 4$ SW $1 / 4$ See. 4, T. 1 S, R. 1 TV, M. D. B. and M.

132. Near southeast corner of NW $1 / 1$ SW $1 / 1$ Sec. 4, T. $1 \mathrm{~S}$, R. 1 W, M. D. B. and $\mathrm{MI}$.

145. On boundary between Acalanes and Sobrantes Grant, 1 mile north of Mount Diablo Base line. Coneord Topographic Sheet, U. S. G. S.

147. About 1 mile north and a little east of old station De Laveaga, which is 4 miles due west of town of Lafayette; on second spur on south side of prominent ridge east of Lauterwasser Creek, $11 / 8$ miles north of Mount Diablo Base line. Concord Topographic Sheet, U. S. G. S.

149. Not quite 1 mile east of Lauterwasser Creele, nearly one-half mile due east of loc. 147, 11/8 miles north of Mount Diablo Base line. Concord Topographic Sheet, U. S. G. S.

351. On south side of Shell Ridge; elevation about 700 feet; five-eighths mile west of east ridge of Concord quadrangle.

402. Little east of saddle which is southwest of 651 -foot hill near west side of NV $1 / 4$ Sec. 30, T. 2 N, R. 1 E, M. D. B. and M.

406. Due west of prominent hill near SE corner NW $1 / 4 \mathrm{SW} 1 / 4$ Sec. $29, \mathrm{~T}, 2$ N, R. 1 E, M. D. B. and M.

407. Near north mouth of tunnel on first point southwest of Selby station. Napa Topographic Sheet, U. S. G. S. 
409. Near south mouth of tunnel on first point southwest of Selby station. Napa Topographic Sheet, U. S. G. S.

410. About three-quarters mile northeast of Hereules Powder Works on bay shore along railroad track; second prominent outerop of gray, coarse sandstone in coming from the powder works. Astrodapsis tumidus subsp. cereboensis found here.

467. A little southeast of Oyster Point; NE 1/4 NE 1/4 See. 28, T. 1 S, R. 1 E, M. D. B. and M. Elevation, 1250 feet.

479. To southwest of Oyster Point, near center of S 1/2 Sec. 20, T. 1 S, R. 1 E, M. D. B. and M. Elevation, 1550 feet.

441. In small gully leading into Riggs Cañon; near center of NE 1/4 Sec. 28, T. 1 S, R. 1 E, M. D. B. and M. Elevation, 1250 feet. Astrodapsis cereboensis found here.

4‘1. In same section and only a little south of loc. 480 but stratigraphically higher. Astrodapsis whitneyi zone.

4... Near center of south side of NW 1/4 See. 28, T, 1 S, R. 1 E, M. D. B. and M. Elevation, 1200 feet.

446. A little southwest of Oyster Point; SW 1/4 SW 1/4 Sec. 21, T. 1 S, R. 1 E, M. D. B. and M. Elevation, 1400 feet.

4ஷ์. Just east of Riggs Cañon; NE 1/4 SW 1/4 See. 27, T. 1 S, R. 1 E, M. D. B. and Ir. Elevation, 1000 feet.

4!II. A little to east of eenter of south side of Sec. 21, T. 1 S, R. 1 E, M. D. B. and $\mathrm{M}$.

4... SW 1/1 SE 1/1 Sec. 21, T. 1 S, R. 1 E, M. D. B. and M. Elevation, 1750 feet.

741. Twenty-five feet stratigraphically a little above loc. 742, Mount Diablo Toprographic Sheet, U. S. G. S.

it2. Twenty-five feet stratigraphically a little above loc. 743 , Mount Diablo Topographic Sheet, U. S. G. S.

743. Near center of north side of $\mathrm{NW} 1 / 4$ See. 28, T. I S, R. 1 W, M. D. B. and II. Elevation, about 1550 feet.

Tt!. In gully just below and a little southwest of 1850 -foot hill almost in middle of line between NIV $1 / 4$ Sec. 24 and NE $1 / 4$ Sec. 23, T. 1 S, R. I W, M. D. B. and M.

7.:. On spur running south from 1594-foot hill; NV 1/t SE 1/t See. 27, T. $1 \mathrm{~S}$, R. 1 E, M. D. B. and M.

7.3. On west side of 1594-foot hill; SW $1 / 4$ NE $1 / 4$ See. 27, T. 1 S, R. 1 E, M. D. B. and M. Elevation, about 1500 feet.

7.i. . On spur due west of 1594-foot hill a little east of center of $\mathrm{NW}_{1 / t}$ Sec. 27, T. 1 S, R. 1 E, M. D. B. and M. Elevation, about 1350 feet.

761. Near center of NW 1/4 Sec. 36, T. 1 S, R. 1 E, M. D. B. and M. Elevation, about 1300 feet.

7i2. Near middle of north line of NE 1/4 NE 1/4 Sec. 2S, T. 1 S, R. 1 E, M. D. B. and M. Elevation, about 1500 feet.

ini. On south side of 1512 foot hill hetween elevation of 1450 and 1500 feet in NE $1 / 4$ NE $1 / 4$ Sec. 29, T. 1 S, R. 1 E, M. D. B. and M.

iil. A little east of center of NE 1/4 NE $1 / 4$ Sec. 28, T. 1 S, R. 1 E, M. D. B. and M. Eleration, 1400 feet.

F:.. In NE corner of NW 1/t NW Sec. 15, T. 1 W, R. 1 S, M. D. B. and M. Elevation, about 751 feet.

7i. A little east of center of SE $1 / 4$ SE $1 / 4$ See. 20, T. 1 S, R. 1 E, M. D. B. and M. Elevation, about 1350 feet. 
1182. About one-eighth mile up gully from corner of See. 15, T, 1 S, R. 2 W, M. D. B. and M.

1195. About 1 mile almost due north of the town of Lafayette, on south side of Lafayette Ridge. Elevation, about 850 feet. Concord Topographie Sheet, U. S. G. S.

1196. About $1 \frac{1}{2}$ miles southeast, air line, of town of Lafayette, a little east of road which erosses ridge going the dixection of Las Trampas Creek and just above the letter $B$ of the word Baseline, as seen on the Concord Topographic Sheet, 1897 edition.

1197. About 21/4 miles, air line, to east and a little south of the town of Lafay. ette; $41 / 8$ inches west of east edge of Concord sheet and $81 / 4$ inehes south of north edge. Concord Topographic Sheet, U. S. G. S., 1897 edition.

1199. On the top of Lafayette Ridge, a little over 1 mile northeast of the town of Lafayette; about where the letter $\mathrm{E}$ comes in the word Ridge, Concord Topographic Sheet, U. S. G. S., 1897 edition.

1219. A little west of loc. 1182, near middle of west edge of SW $1 / 4$ SW $1 / 4$ Sec. 15 , T. 1 S, R. 2 W, M. D. B. and M.

1221. A little west of middle of SE $1 / 4$ NE $1 / 4$ Sec. 9, T. $1 \mathrm{~S}, \mathrm{R} .2 \mathrm{~W}, \mathrm{M} . \mathrm{D}, \mathrm{B}$. and $\mathbf{M}$.

1224. Near south edge of NE $1 / 4$ NE $1 / 4$ Sec. 2, T. 2 S, R. 2 W, M. D. B. and M. Elevation, about 1300 feet.

12:5. In gulch on north side of Bolinger Cañon, near NE corner of SIV $1 / 4$ NIV $1 / 4$ Sec. 31, T. 1 S, R. 1 W, M. D. B. and M. Elevation, about 1150 feet.

120- A little west of center of SE $1 / 4$ NE $1 / 4$ Sec. 9, T. 1 S, R. 2 IV, M. D. B. and M. Stratigraphically bigher than loe. 1221.

1231. South of Las Trampas Ridge in first gully north of divide between Bolinger Creek and Las Trampas Creek; elevation about 410 feet. Concord Topographic Sheet, U. S. G. S.

1237. At elevation of about 1350 feet; near NW corner of Sec. 2i, T. 1 S, R. 2 W, M. D. B. and M.

1239. On north side of Grizzly Creek, near middle of north edge of Sec. 15, T. 1 S, R. 2 W, M. D. B. and M. Elevation, about 850 feet.

1240. A little over one-half mile from head of guleh, near SE corner of NE $1 / 4$ NW $1 / 1$ Sec. 22, T. 1 S, R. 2 WV, M. D. B. and M.

124.). Near SE corner of NE $1 / 4$ SE $1 / 4$ See. 16, T. 1 S, R. 2 W, M. D. B. and II.

1:49. A little south of NW corner of NW $1 / 4$ NE $1 / 4$ Sec. 21, T. 1 S, R. 2 W, MI. D. B. and M. Elevation, about 850 feet.

12.51. Near SE corner of SE $1 / 4$ SW 1/4 See. 15, T. $1 \mathrm{~S}, \mathrm{R}, 2$ W, M. D. B. and II.

12.7. Near middle of west edge of NW $1 / 4$ SW $1 / 4$ Sec. 1, T. 2 S, R. 1 W, M. D.

B. and M.; near head of gulch. Elevation, about 800 feet.

126i.5. A little east of center of See. 9, T. I S, R. 2 W, M. D. B. and M.

1270. Near south edge of NE $1 / 4$ NE $1 / 4$ Sec. 36, T, 1 S, R. I W, M. D. B. and M.

1.73. Near SE corner of NW 1/4 SE 1/t See. 31, T. 1 S, R. 1 W, M. D. B. and M. Elevation, about 1300 feet.

127t. At end of branch road as shown on Concord sheet, 1897 edition; near NE corner Sec. 22, T. 1 S, R. 2 W, M. D. B. and M.

1275. On peak just north of middle of south edge of See. 16, T. 1 S, R. 2 W, M. D. B. and M.

1474. Near SE corner of NE $1 / 4$ Sec. 24, T. $1 \mathrm{~S}, \mathrm{R} .1$ W, M. D. B. and M. 
147\%. On south side of 1010 -foot hill at elevation of about 775 feet; near SE corner of NE $1 / 4$ See. 5 , T. 1 S, R. 1 W, M. D. B. and M.

1479. In gully leading up to Wall Point; near middle of north edge of NE $1 / 4$ NW 1/4 Sec. 15, T. 1 S, R. 1 W, M. D. B. and M. Elevation, about 775 feet.

14\$3. On southeast side of 800 -foot hill, along face of prominent ledge; near SE corner of NIV 1/4 NE $1 / 4$ See. 25, T. 1 N, R. 1 WV, M. D. B. and M.

144.). Near west edge of SE $1 / 4$ NW $1 / 4$ Sec. 19, T. 1 E, R. 1 S, M. D. B. and M. Elevation, about 1250 feet.

145S. Stratigraphically higher than loc. 1485; close to west edge of SW $1 / 1$ NW $1 / 4$ Sec. 19, T. 1 S, R. 1 E, M. D. B. and M. Elevation, about 1000 feet.

1490. A little south of loe. 1485 and at about the same horizon; near SW corner of SE $1 / 4$ NW 1/4 Sec. 19 , T. 1 S, R. 1 E, M. D. B. and MI.

1491. On south side and below east peak of 1010-foot hill at elevation of about 900 feet; close to south boundary of NE $1 / 4$ Sec. 5, T. I S, R. 1 W, M. D. B. and M.

149.5. Near NW corner of SE $1 / 4$ SE $1 / 4$ Sec. 14, T. 7 S, R. 1 W, MI. D. B. and Mr. Elevation, about 1000 feet.

1496. In same gully and not quite 100 feet in elevation lower than loc. 1495; just below prominent shale band. Mount Diablo Topographical Sbeet, U. S. G. S.

1499. Near NE corner of NW $1 / 4$ SW $1 / 4$ Sec. 15, T. 1 S, R. 1 W, M. D. B. and M.

1501. On south side of 1061-foot hill; near NE corner of STV $1 / 4$ Sec, 15, T. 1 S, R. 1 W, M. D. B. and M.

1504. Just above lowest prominent band of shale in San Pablo; in SE $1 / 4$ SE $1 / 4$ Sec. 14, T. 1 S, R. I W, M. D. B. and MI. Elevation, about 900 feet.

1514. On south side of 1061-foot hill, stratigraphically lower than loc. 1501; near NW corner of SE $1 / 4$ Sec. 15, T. 1 S, R. 1 W, M. D. B. and M.

1518. Near south edge of NE $1 / 4$ NW 1/4 See. 15, T. 1 S, R. 1 W, M. D. B. and M.

1520. A little northwest and in next gully from loc. 1518 and in practieally the same horizon; elevation about 650 feet; near SE corner of NW $1 / 4$ Sec. 15 , T. 1 S, R. 1 IV, M. D. B. and M.

1532. A little over 2 miles southeast of the town of Roleo and about onequarter mile due west of 700 -foot hill; a medium fine, hard, caleareous sandstone just below coarse, cross-bedded sandstone; irregular contact between these two members. Napa or Karquinez Topographic Sheet, U. S. G. S.

1793. About three-quarters mile east and a little south of town of Rodeo, just below prominent shale band in San Pablo; on the Napa Topographic Sheet, U. S. G. S., 1902 edition, it is just below the first letter $O$ in the word liorleo.

1600. About 21/3 miles east and a little south of the town of Rodeo on south side of 700 -foot hill near the head of a deep north and south gulch. Napa Topographic Sheet, U. S. G. S.

1604. In medium fine sandstone in upper San Pablo, about three-quarters mile east and a little south of town of Rorleo, about 1 mile west and a little north of 700 -foot hill; higher stratigraphically than loc. 1532. Napa Topographic Sheet, U. S. G. S.

1605. About $1 \frac{1 / 4}{4}$ miles southeast of tunnel just south of Tormey station; a little southeast of 407 -foot hill on top of ridge. Napa Topographic Sheet, U. S. G. S. 
1606. About 1 mile southeast of Tormey station, on south side of valley of Canada del Cerebo; on northeast end of 407-foot hill; stratigraphically below loc. 1605. Napa or Karquinez Topographic Sheet, U. S. G. S.

1607. On hill over tunnel just south of Tormey station, in quarry just west of big oil tank, in coarse sandstone on north side of quarry. Napa Topographie Sheet, U. S. G. S.

1608. Stratigraphically 30 or 40 feet above loc. 1607 and on south side of same quarry, Napa Topographic Sheet, U. S. G. S.

1609. About 11/4 miles southeast of Tormey station, on south side of Canada del Cerebo Valley; on northeast end of 407 -foot hill shown on Karquinez Topographic Sheet, U. S. G. S., also Napa Topographic Sheet, U. S. G. S.

1610. About 11/2 miles northeast of town of Rodeo, south and a little east of 407-foot hill shown on Karquinez Topographic Sheet, U. S. G. S.; just below prominent shale band in San Pablo.

1611. About $1 \frac{1}{1}$ miles east of town of Rodeo, about 150 yards north of cement house; a coarse, gray sandstone just below shale in middle San Pablo. Xapa Topographie Sheet, U. S. G. S.

1612. About $11 / 4$ miles north of town of Rodeo, about one-half mile southeast of Union Oil Works and on same strike; beds stratigraphically about 100 feet above prominent shale band in middle San Pablo. Napa Topographic Sheet, U. S. G. S.

1613. About 25 feet stratigraphically above loe. 1612; same general locality.

1611. About one-half mile east of town of Rodeo in creek bed a little east of house at end of branch road; above the first letter $O$ in the word Rodeo, as seen on Napa Topographic Sheet, U. S. G. S., 1902 edition.

1615. In same horizon as loc. 1614, near barn to west of house mentioned in deseription of loc. 1614.

1617. About one-quarter mile east of Rodeo, stratigraphically about 150 feet below Pinole tuff. As seen on Napa Tonographic Sheet, 1902 edition, it is due west of the top of the letter $\mathrm{R}$ of Rodeo. Cyrena californica is found here in great abundance.

1618. From a well just baek of house a little east and about 100 feet north across strike of beis found at loc. 1617 ; well 30 feet deep; probably penetrates same horizon as loc. 1617 .

1619. Abont three-quarters mile due east of Rodeo, north of middle of big bend in Santa Fe railroad and west and a trifle north of 700 -foot hill, as seen on Napa Topographie Sheet, U. S. G. S., 1902 edition. Stratigraphically this locality is some distance below the prominent shale member in the San Pablo.

1620. About 11/2 miles east and a little north of town of Rodeo, on north side of syncline on east end of prominent knob just south of 407 -foot hill, as shown on Karquinez Topographic Sheet, 1897 edition; stratigraphieally above the prominent shale member of this section; stratigraphically above loc. 1610 .

1621. Along road not more than 50 feet to south of and stratigraphically below loc. 1617 .

1622. About 200 feet south of house and loe. 1617. Spring cemented up; leaf. collection obtained here.

16:4. About 1 mile southwest of town of Rodeo, a little over 1 mile due west of 700 -foot hill. Irregular contact between coarse conglomeratic sandstone and medium fine, yellow sandstone. 
162.). About 1 mile northeast of town of Rodeo, on north side of syncline; about three-quarters mile southeast of Union Oil Works; about 190 feet stratigraphieally below base of Pinole tuff, to north of chicken coop in gully below eement house. Napa Topographic Sheet, U. S. G. S.

1626. Coarse gray sands near base of San Pablo on north side of syncline about 2 miles northeast of town of Rodeo; about $1 \frac{1}{1}$ miles southeast of Tormey station; near end of long ridge on south side of Canada del Cerebo Valley. Napa Topographic Sheet, U. S. G. S.

10.7. About 21/2 miles east and a little south of town of Rodeo, in gulch at elevation of about 600 feet. As seen on Napa Topographic Sheet, 1902 edition, it is due south of the letter D in the word Del Hambre; coarse gray conglomeratic sandstone.

1628. About three-quarters mile due east of loc. 1627 and in same horizon; coarse basal sandstones of San Pablo; due north of big bend in Santa Fe railroad. Napa Topographic Sheet, U. S. G. S.

1629. On top of ridge to north of big bend in Santa Fe railroad, a little east of loc. 1628 and in same horizon.

1630. About 3 miles, air line, southeast of town of Rodeo, on top of ridge east of 700-foot bill, where road from Crockett crosses; just below the letter $\mathrm{E}$ of the word del, Napa Topographic Sheet, U. S. G. S.

1631. About one-quarter mile due east of town of Rodeo, between 150 and 200 yards east of loe. 1617 and a little higher stratigraphically. Napa Topographic Sheet, U. S. G. S.

1fi3.. Pecten beds on bay shore just west of the town of Rodeo, a little south of Lone Tree Point; described in the Pae. R. R. Repts.

163:. About 75 to 100 feet southeast and directly across the strike from loc. 1631, and lower stratigraphically.

1694. In gully on south side of 700 -foot hill, south and a little west of town of Crockett; elevation about 500 feet; west of and in same horizon as loc. 1627. Napa Topographic Sheet, U. S. G. S.

1036. About 3 miles south of town of Danville, in quarry back of second house west of bend in county road. Mount Diablo Topographic Sheet, U. S. G. S.

1590. About 150 feet above base of San Pablo Group on west edge of NW 1/1 Sec. 33 , T. 2 N, R. 1 E, M. D. B. and M.

1891. On south side of 594-foot hill and very near the top of the hill, near center of SW 1/4 Sec. 29, T. 2 N, R. 1 E, M. D. B, and M.

1893. North of Mount Diablo, about 1 mile east of Kirker Creek, a little abore the base of the San Pablo; about 100 feet south of and stratigraphically below loc. 1890. Mount Diablo Topographic Sheet, U. S. G. S.

1894. On east side of hill, just above base of San Pablo; a little west of center of SW $1 / 4 \mathrm{SE} 1 / 4$ Sec. 29 , T. 2 N, R. 1 E, M. D. B. and M.

1936. Southwest of Mount Diablo, on knoll just northwest of highest point in row of knobs south of Shell Ridge and about 575 feet in eleration. Coneord Topographie Sheet, U. S. G. S.

19:7. Highest point described in deseription of loc. 1936. Coneord Topographic Sheet, U. S. G. S.

1934. About 150 feet southeast of loc. 1937 and half way down hillside in gulch. Concord Topographie Sheet, U. S. G. S. 
1940. About 11/2 miles southeast of town of Walnut Creek, in gully opening toward the northwest in ridge southwest of Shell Ridge; almost due south of the first letter $\mathrm{S}$ in the word Nuecesy Bolbones, as seen on the Coneord Topographic Sheet, U. S. G. S., 1897 edition.

1934. About 11/2 miles east of town of Walnut Creek, on ridge parallel to and south of Shell Ridge; on the east end of the northern of the two knolls which lie just southeast of the letter $\mathrm{S}$ in the word Shell, as seen on the Coneord Topographic Sheet, 1897 edition; elevation, about 350 feet.

1944. A little west of and lower in altitude but higher stratigraphically than loc. 1936; on the side of the same hill. Concord Topographic Sheet, U. S. G. S.

1945. In gulch just west of loc. 1944 and in same horizon. Coneord Topographic Sheet, U. S. G. S.

1946. Southeast of WValnut Creek, on south side of highest hill in ridge to south of and parallel to Shell Ridge; elevation about 450 feet. In about the same horizon as loc. 1944. Concord Topographic Sheet, U. S. G. S.

1947. On south side of same hill as loc. 1946 ; about 50 feet higher in elevation. Coneord Topographic Sheet, U. S. G. S.

1948. Southeast of Wainut Creek, on top of first knob to west of where creek euts through ridge, which is south of and parallel to shell Ridge. Concord Topographic Slieet, U. S. G. S.

1950. Southeast of Walnut Creek, on top of first knob west of where ereek cuts through ridge which is south of and parallel to Shell Rdige; on small knob just north of knob on whieh loc. 1948 is; stratigraphieally lower. Coneord Topographic Sheet, U. S. G. S.

1952. Southeast of Walnut Creek, on 475-foot contour, where it erosses creek that cuts through ridge south of and parallel to Shell Ridge. Concord Topographic Sheet, U. S. G. S.

1953. Southeast of Walnut Creek, on top of hill east of creek which cuts through ridge south of and parallel with Shell Ridge. Coneord Topographic Sheet, U. S. G. S.

195. Southwest of Walnut Creek, on south side of first knoll west of loc. 1953; in first gully just east of where creek euts through ridge. Concord Topographic Sheet, U. S, G. S.

1955. On little knoll exactly one-third mile southwest of the letter $G$ in the worl shell Ridge, as shown on Coneord Topographic Sheet, U. S. G. S., 1897 edition; in same horizon as loe. 1954.

1958. Southwest of Walnut Creek, near east edge of Coneord Topographic Sheet. It is $81 / 2$ inches from the top of the Concord sheet, 1897 edition, and about one-quarter inch west of the east edge, on east side of 800 -foot hill, above road which erosses Shell Ridge above dairy ranch.

1960. A little south of loc. 1958, about 200 feet north of barn of dairy ranch.

1961. The same general locality as loc. 1958, on south side of hill between house and barn to the east of and about 125 feet above fence which runs near barn. Concord Topographic Sheet, U. S. G. S. 
1962. About three-eighths mile east of loe 1961,15 feet above and on east side of small saddle between a 725 -foot and a 700 -foot knoll, which knolls lie east and west of each other; exactly 1 inch dne south of the letter $\mathrm{E}$ in the word ridge of Shell Ridge. Concord Topographic Sheet, I. S. G. S.

1963. Southeast of Walnut Creek, about 100 feet east of where creek forks, in gulch just west of where creek cuts through the ridge which is to the south of and parallel to Shell Ridge. Coneord Topographic Sheet, I. A. G. S.

2040. On southeast side of 990 -foot hill at elevation of about 650 feet; near sontl edge of NE 1/4 See. 33 , T. 2 N, R. 1 E, M. D. B. and M.

2011. In first sharp gulch just west of 920-foot hill; in bottom of creek bed; SW corner of NE 1/4 Sec. 33, T. 2 N, R. 1 E, M. D. B. and M.

2042. A little east of center of NW $1 / 4$ SW $1 / 1$ Sec. $34, T, 2$ N, R, 1 E, M. D. B. and $\mathrm{M}$. 



\section{EXPLANATION OF PLATE 42}

All figures approximately natural size

Fig. 1. Astrodapsis uhitneyi Rémond. A very characteristic species in the lower part of the Upper Division of the San Pablo. Anteroposterior diameter, $60 \mathrm{~mm}$.

Fig. 2. Mytilus trampasensis, n. sp. An imperfect specimen of a left valve. Longitude, $66 \mathrm{~mm}$.

Fig. 3. Nytilus trampasensis, n. sp. An imperfect specimen of a right valve, showing shape of posterior end.

Fig. 4. Modiolus directus Dall. Longitude, $43 \mathrm{~mm}$.

Fig. 5. Mytilus perrini, n. sp. Always found associated with brackish water species such as Cyrena (Corbicula) californica and Mya dickersoni. Longitude, $39 \mathrm{~mm}$.

Fig. 6. Mytilus perrini, n. sp. Longitude, $55 \mathrm{~mm}$. 

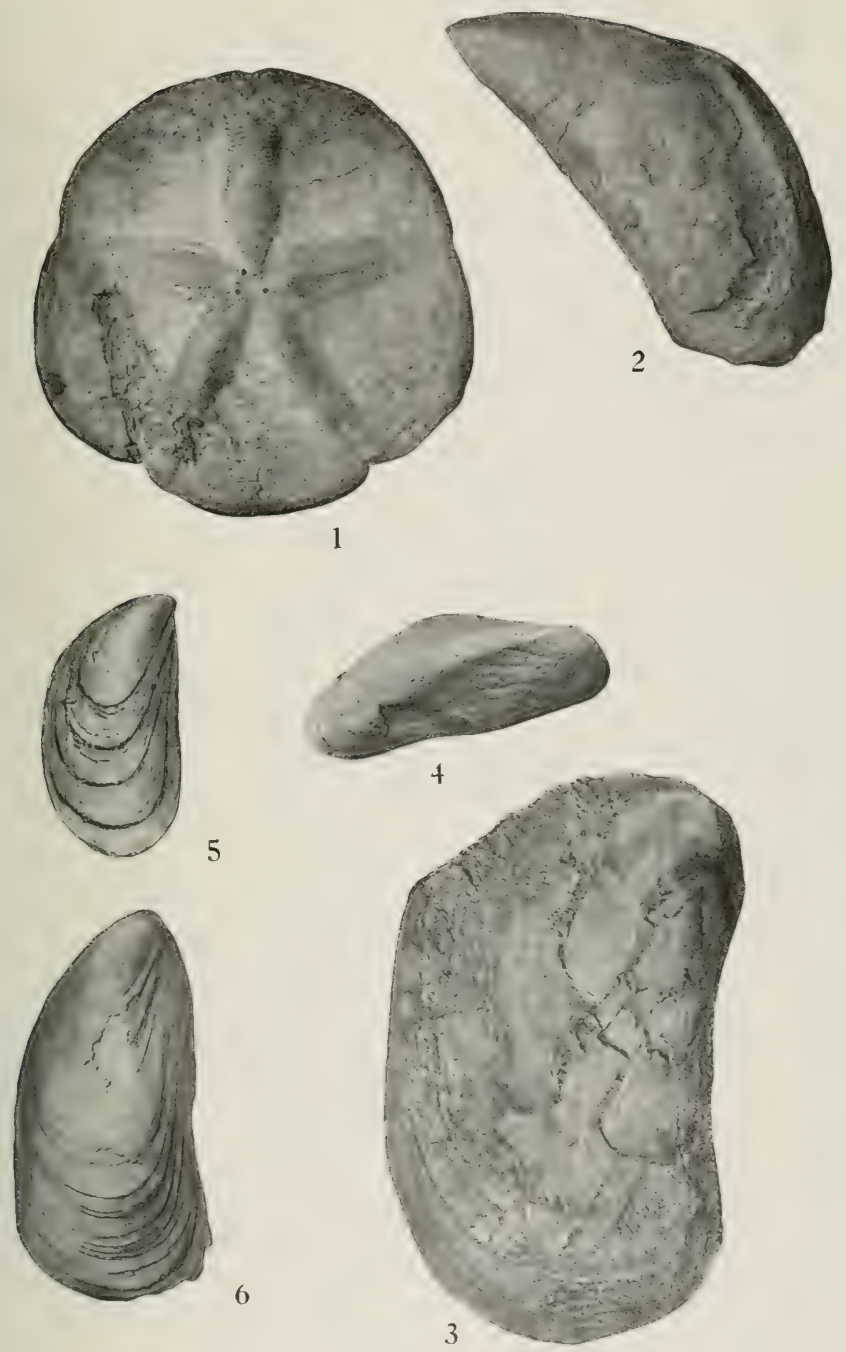




\section{EXPLANATION OF PLATE 43}

Approximately two-thirds natural size

Osterea bourgeoisii Rémond. A very common species in the Lower San Pablo and in the Scutella breweriana zone. Longitude, about $200 \mathrm{~mm}$. 


$$
8
$$






\section{EXPLANATION OF PLATE 44}

All figures approximately natural size

Fig. 1. Ostrea titan Conrad. This species is sometimes gigantie in proportions, being as much as 18 inches high, with the shell several inches thick.

Fig. 2. Solen perrini, n. sp. Longitude, $76 \mathrm{~mm}$.

Fig. 3. Siliqua lucida Conrad. Longitude, $18 \mathrm{~mm}$. 

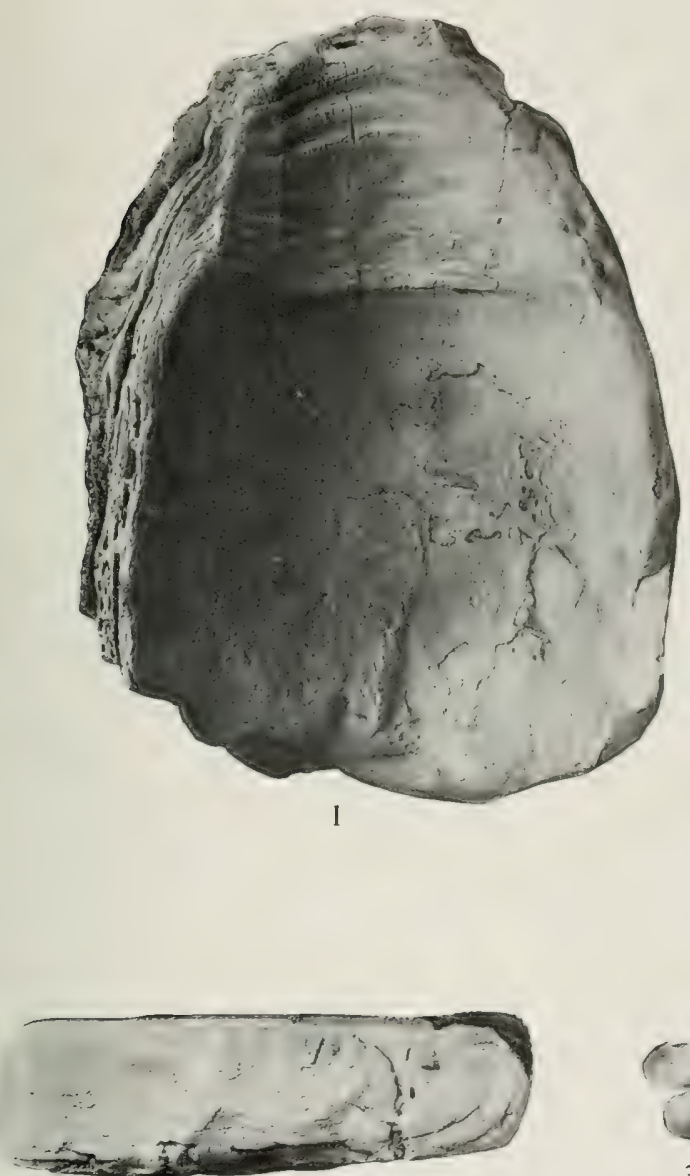

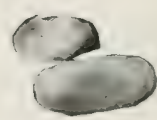

3 



\section{EXPLANATION OF PLATE 45}

Fig. 1. Pecten weateri, n. sp. Left valre. A common species in the Lower San Pablo of the type section. Longitude, $57 \mathrm{~mm}$. Natural sıze.

Fig. 2. Pecten weaveri, n. sp. Right valve. Natural size.

Fig. 3. Pecten crassicardo Conrad. Right valve. Common in both the Upper and Lower San Pablo. Longitude, $150 \mathrm{~mm}$. About two-thirds natural size. 

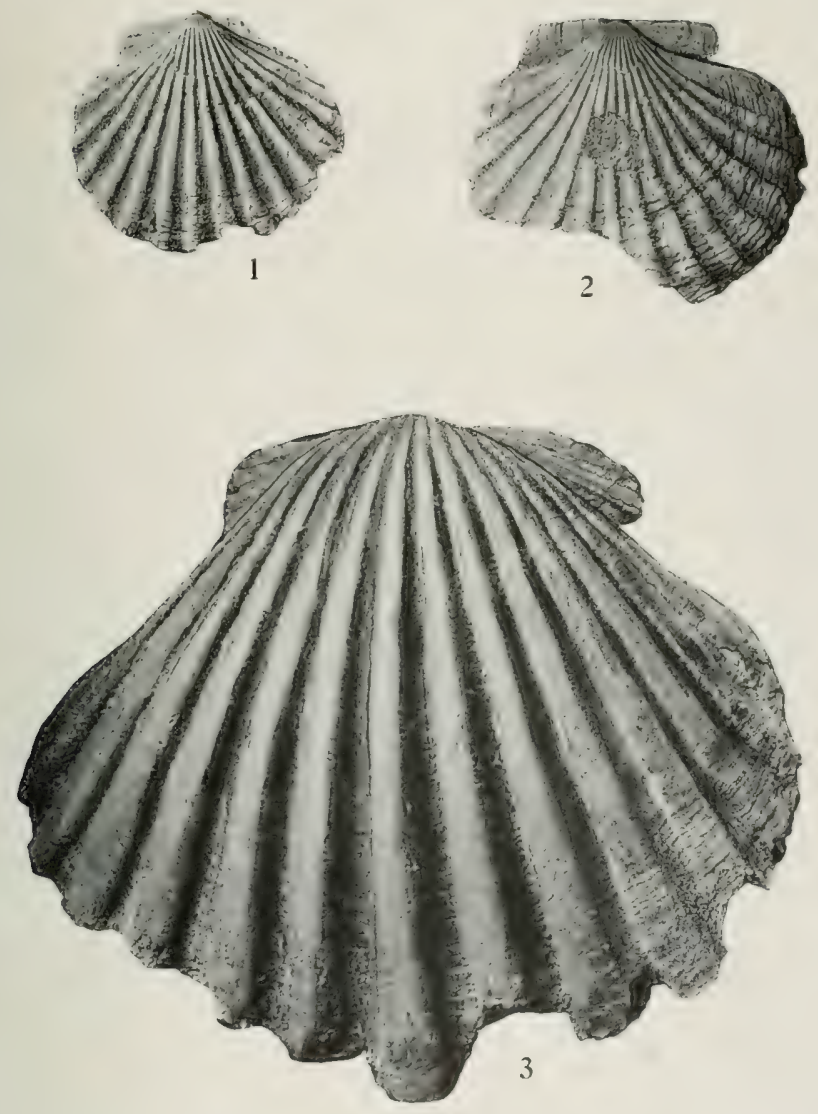



\section{EXPLANATION OF PLATE 46}

Fig. 1. Pecten (Pecten) raymondi, n. sp. Right valve. A very common species in the San Pablo and the Scutella breweriana zone. Believed to be charaeteristic of the Upper Miocene. Longitude, $43 \mathrm{~mm}$. Natural size.

Fig. 2. Pecten (Pecten) raymondi, n. sp. A very large specimen of the convex left valve. Longitude, $50 \mathrm{~mm}$. Figure slightly enlarged.

Fig. 3. Pecten (Lyropecten) crassicardo Conrad nov. var.? Right valve. Longitude, $132 \mathrm{~mm}$. Approximately two-thirds natural size. 

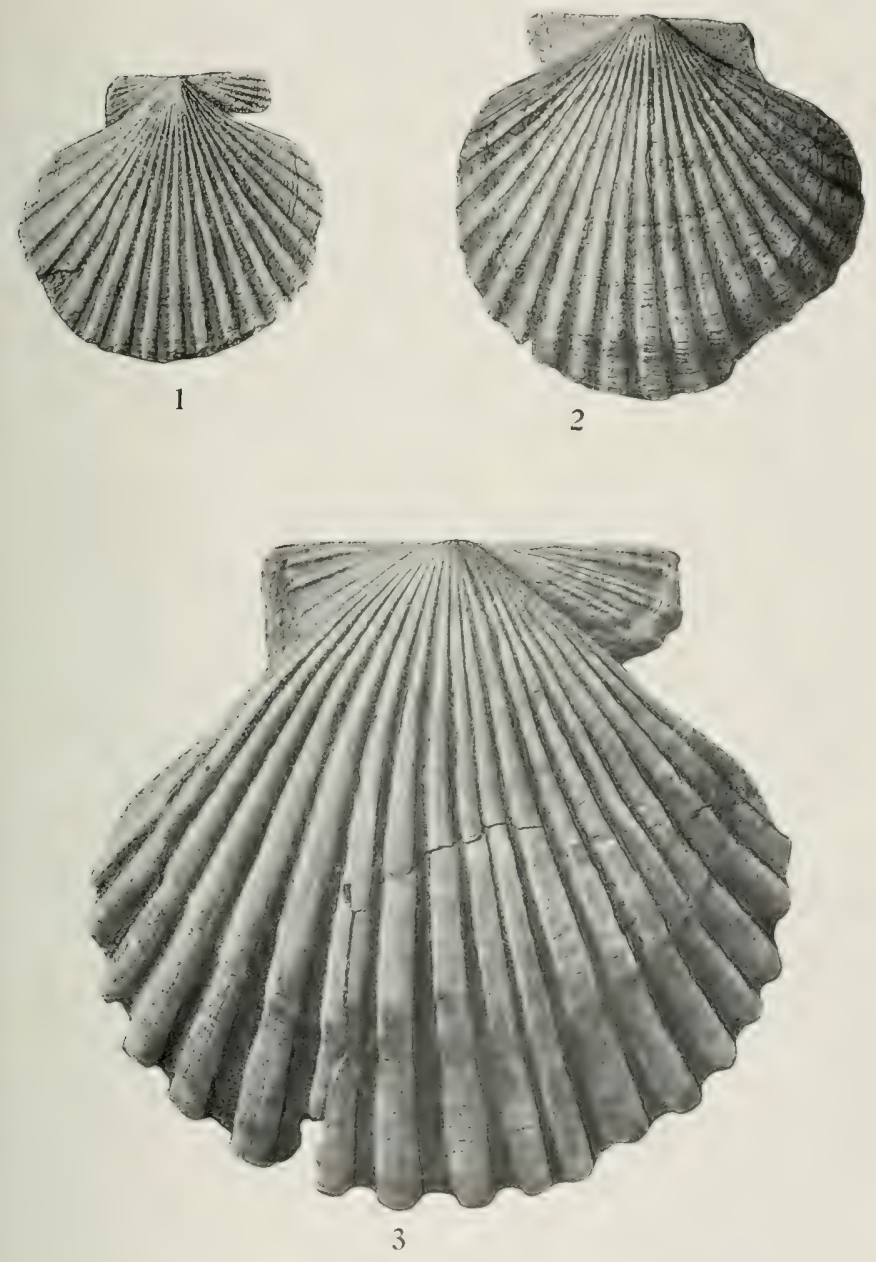




\section{EXPLANATION OF PLATE 47}

All figures approximately natural size

Fig. 1. Pecten (Pecten) raymondi, n. sp. Left valve. Longitude, $30 \mathrm{~mm}$. Fig. 2. Pecten (Pecten) raymondi, n. sp. Right valve. Longitude, $22 \mathrm{~mm}$. Fig. 3. Cardium quadrigenarium Conrad. Longitude, $38 \mathrm{~mm}$.

Fig. 4. Pecten estrellanus Conrad. Right valve. Longitude, $29 \mathrm{~mm}$. Fig. 5. Pecten holwayi, n. sp. Right valve. Lungitude, $91 \mathrm{~mm}$. Fig. 6. Pecten cierboensis, n. sp. Right valve. Longitude, $17 \mathrm{~mm}$. Fig. 7 . Pecten crassiradiatus, $\mathrm{n}$, sp. Right valve. Height, $47 \mathrm{~mm}$. Fig. S. Pecten pabloensis Conrad. Right valve. Longitude, $39 \mathrm{~mm}$. 

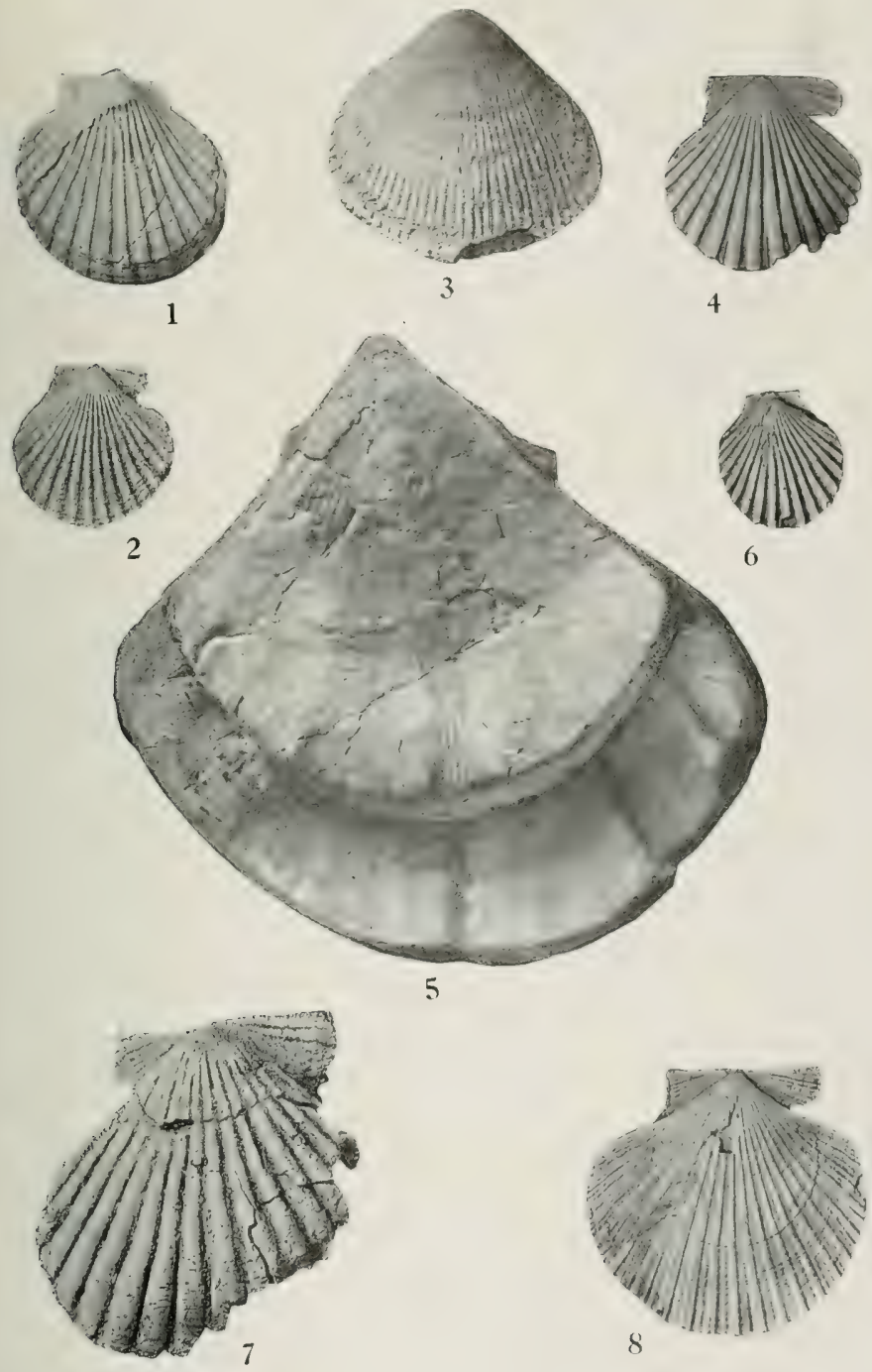




\section{EXPLANATION OF PLATE 48}

All figures approximately natural size

Fig. 1. Modiolus gabbi, n. sp. Longitude, $69 \mathrm{~mm}$. Apparently a very charaeteristic species of the Upper Miocene.

Fig. 2. Pecten pabloensis Conrad. Left valve. Longitude, $33 \mathrm{~mm}$.

Fig. 3. Pinna alamedensis Yates. Longitude of imperfect specimen, $135 \mathrm{~mm}$. A very common species in the Upper San Pablo. Also reported from the Lower Miocene of Southern California.

Fig. 4. Glycimeris septentrionalis Middendorf. Longitude, $24 \mathrm{~mm}$.

Fig. 5. Arca trilineata Conrad. A very common species in the Upper Miocene and Pliocene of the west coast. Also reported from the Lower Miocene.

Fig. 6. Yoldia carnarosensis, n. sp. Longitude, about $40 \mathrm{~mm}$.

Fig. 7. Mytilus merriami, n. sp. Longitude, about $105 \mathrm{~mm}$.

Fig. 8. Mytilus merriami, n. sp. Same specimen as figure 7 .

Fig. 9. Glycimeris coalingensis Arnold. Specimen from Lower San Pablo. Longitude, $32 \mathrm{~mm}$.

Fig. 10. Glycimeris coalingensis Arnold. Specimen from Upper San Pablo. Longitude, $36 \mathrm{~mm}$. 


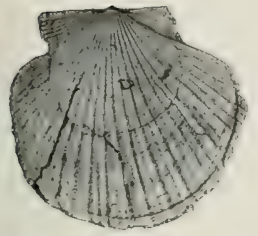

2
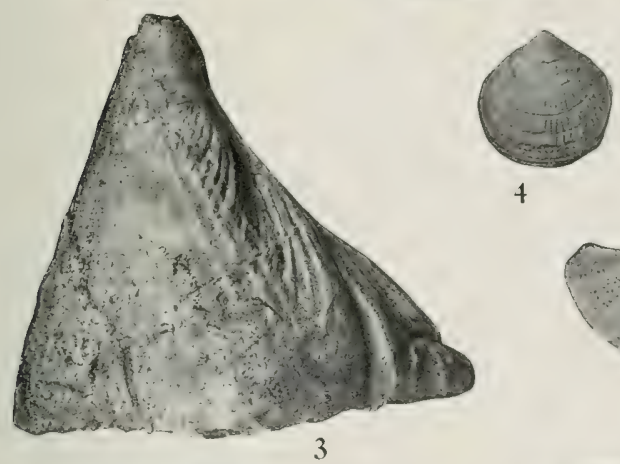

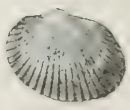

4

5
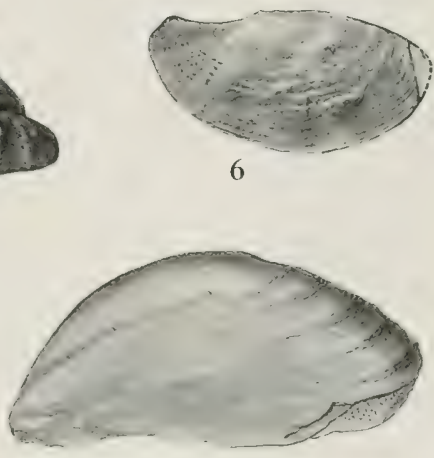

7

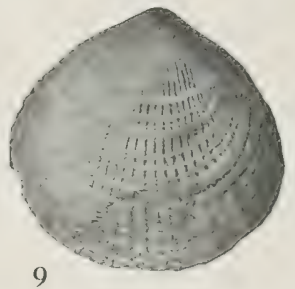





\section{EXPLANATION OF PLATE 49}

Figures approximately natural size

Fig. 1. Dosinia merriami, n. sp. Right valve. Longitude, $90 \mathrm{~mm}$.

Fig. 2. Dosinia merriami, n. sp. Hinge plate of right valve of same specimen as figure 1 . 

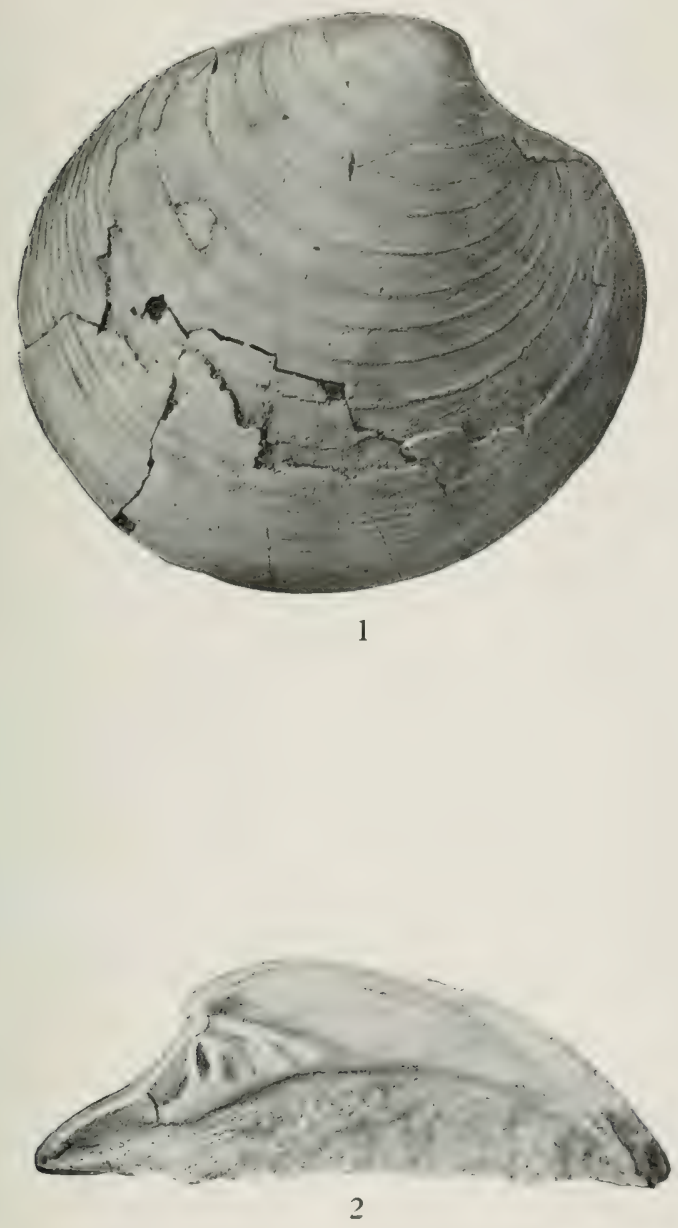




\section{EXPLANATION OF PLATE 50}

All figures approximately natural size

Fig. 1. Dosinia merriami, n. sp. var. occidentalis, n. var. A very common species in the Upper San Pablo. Longitude, $80 \mathrm{~mm}$.

Fig. 2. Amiantis dalli, n. sp. Left valve, Found in the Upper San Pablo. Longitude, about $85 \mathrm{~mm}$. 

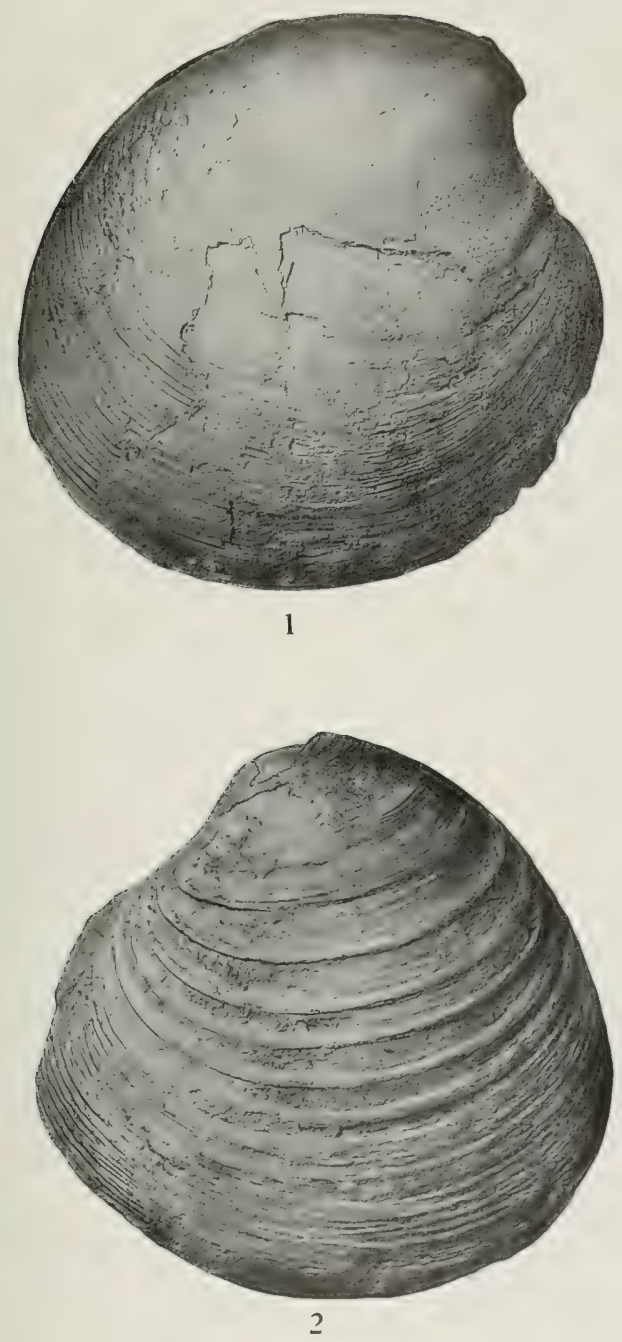



\section{.}




\section{EXPLANATION OF PLATE 51}

All figures approximately natural size

Fig. 1. Dosinia arnoldi, n. sp. Hinge plate of left valve. A common species in the Upper San Pablo, Longitude, $85 \mathrm{~mm}$.

Fig. 2. Dosinia arnoldi, n. sp. Exterior view of specimen shown in figure 1. 

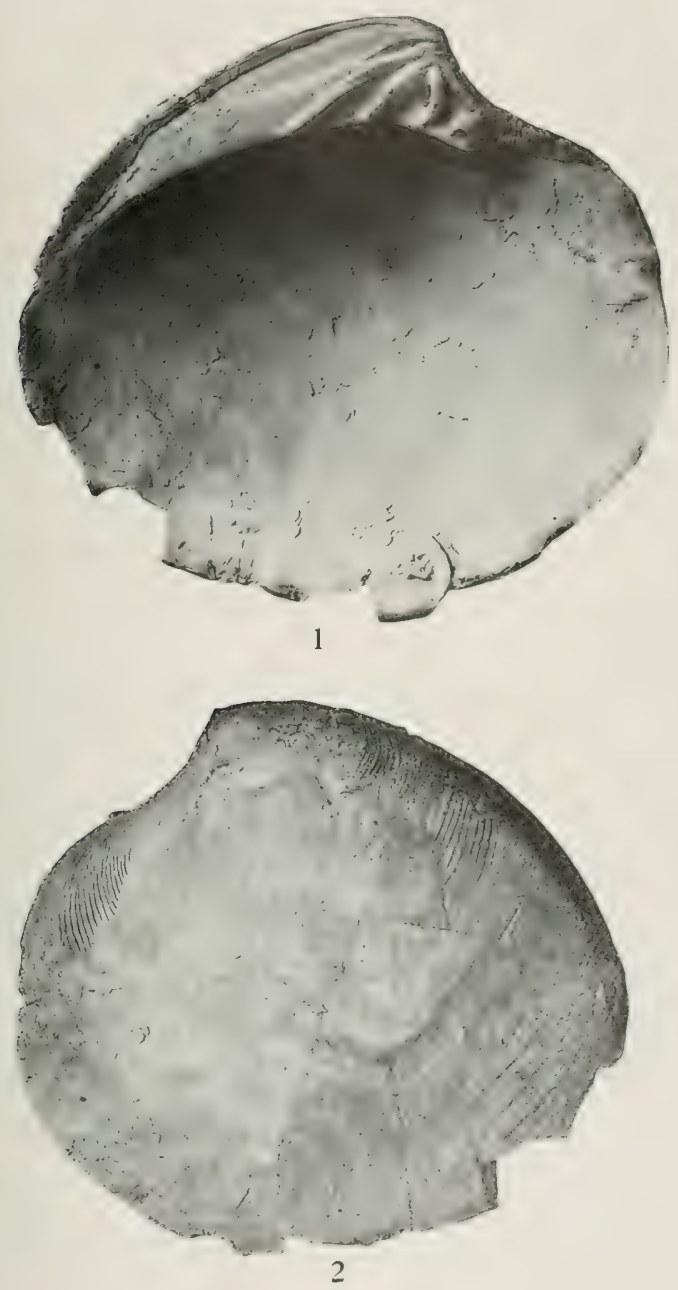




\section{EXPLANATIGN OF PLATE 52}

All figures approximately natural size

Fig. 1. Dosinia merriami, n. sp. Right valve. Longitude, $95 \mathrm{~mm}$. Fig. 2, Dosinia merriami, n. sp. Hinge plate of left valve. 

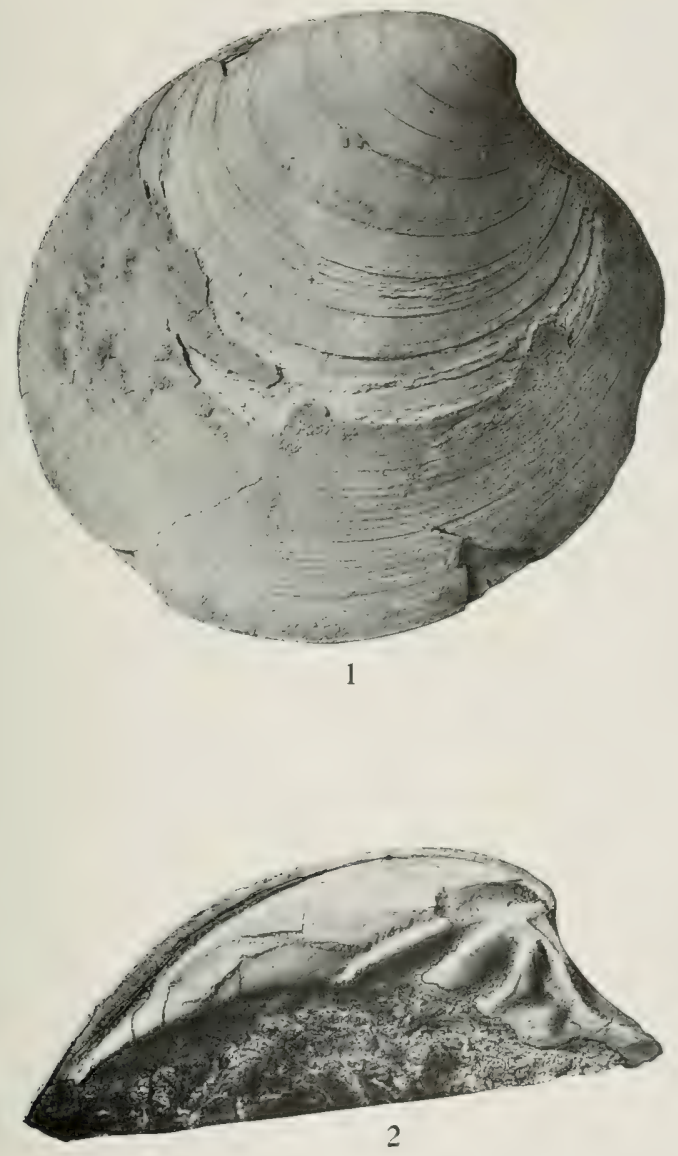



\section{EXPLANATION OF PLATE 53}

All figures approximately natural size

Fig. 1. Amiantis dalli, n. sp. Left valve. Longitude, $72 \mathrm{~mm}$.

Fir. ".. Amiantis dalli, n. sp. Anterior view of same specimen as figure 1.

Fig. 3. Amiantis dalli, n. sp. Hinge plate of left valve. This specimen shown also on plate 50 , figure 2.

Fin. 4. Amiantis dalli, n. sp. Hinge plate of right valve.

Fin. 5. Pitaria stalderi, n. sp. Hinge plate of left valve, Longitude, $59 \mathrm{~mm}$.

Fin. 6. Pitaria stalderi, n. sp. Right valve, Longitude, $64 \mathrm{~mm}$. 

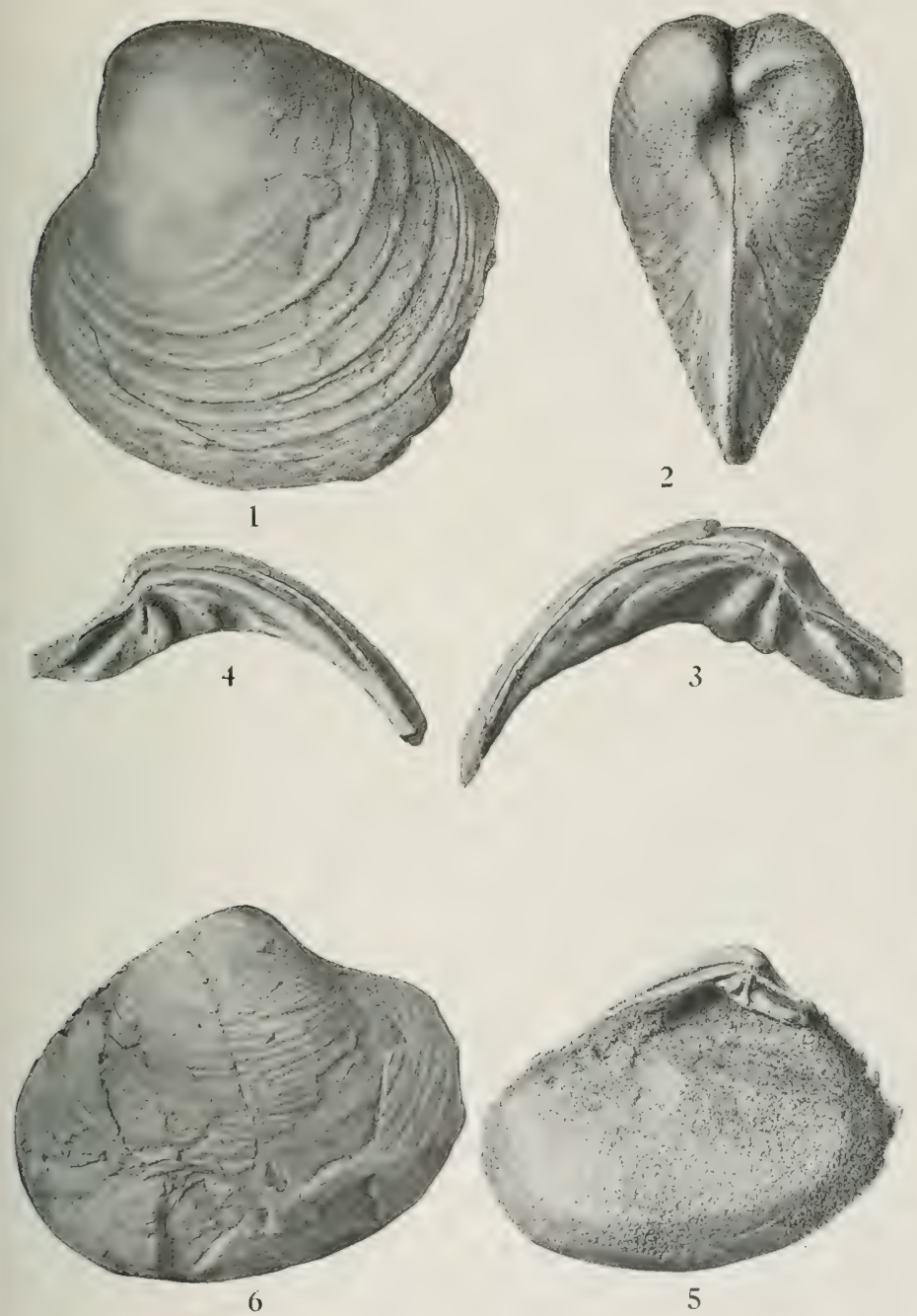

5 




\section{EXPLANATION OF PLATE 54}

All figures approximately natural size

Fin. 1. Venus martini, n. sp. A common species in the Astrolapsis whitncyi zonle?

Fig. 2. Pitaria behri, n, sp. Anterior view. Showing lunule on posterior horsal area.

Fig. 2. Pitaria behri, n. sp. Left valve, Longitude, $64 \mathrm{~mm}$.

Fig. 4. Pitaria beleri, n. sp. Hinge plate of left valve.

His. 5. Tivela diabloensis, n. sp. Interior view of right valve.

Fig. 6. Tivela diabloensis, n. sp. Exterior view of same specimen as figure i. Longitude, $59 \mathrm{~mm}$. 

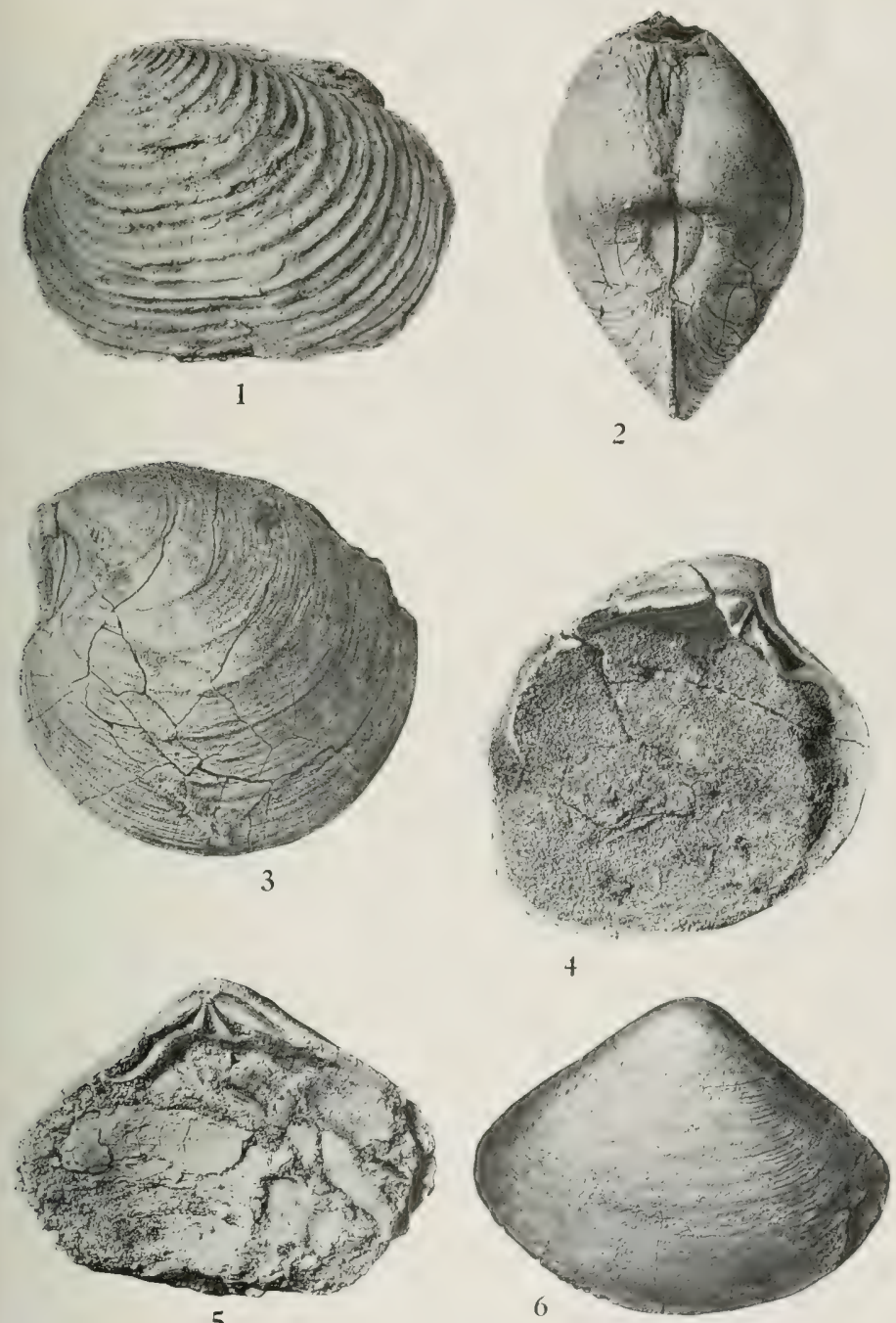



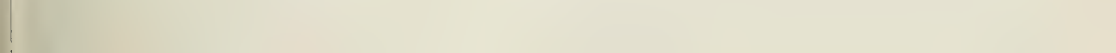




\section{EXPLANATION OF PLATE 55}

All figures approximately natural size

Fig. 1. Tivela diabloensis, n. sp. Type, left valve. Longitude, $91 \mathrm{~mm}$. Fig. 2. Tivela gabbi, n, sp. Type, left valve. Longitude, $86 \mathrm{~mm}$. 




\section{EXPLANATION OF PLATE 56}

All figures approximately natural size

Fig. 1. Tivela diabloensis, n. sp., var. angulatum, n. var. Right valve. Longitude, $58 \mathrm{~mm}$.

Fig. 2. Cyrena (Corbicula) californica Gabb. Right valve. Longitude, $3 \mathrm{~mm}$.

Fig. 3. Tivela gabbi, n. sp. Right valve.

Fig. 4. Tivela gabbi, n. sp. Hinge plate of right valve. This specimen shown also on plate 15 , figure 2.

Fig. 5. Paphia staminea Conrad, Longitude, $35 \mathrm{~mm}$. 

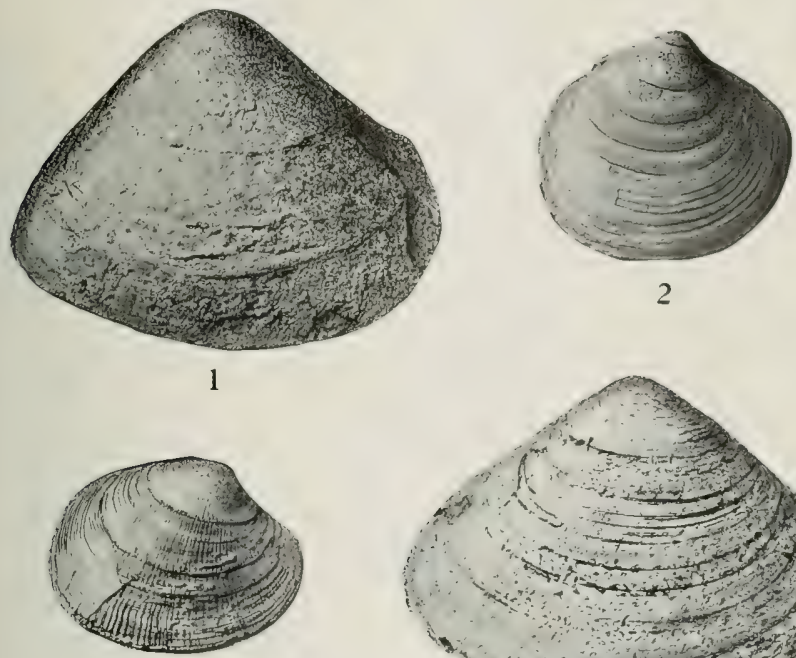

5
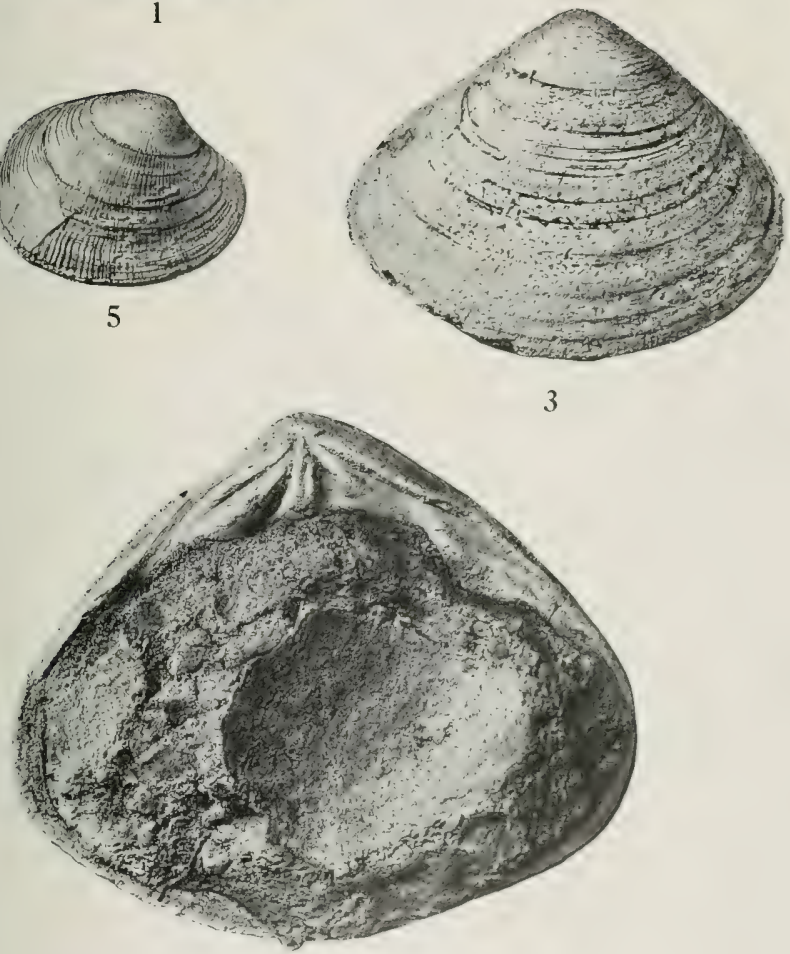



\section{EXPLANATION OF PLATE 57}

All figures approximately natural size

Fig. 1. Saxidomus nuttallii Conrad. Left valve. Longitude, $112 \mathrm{~mm}$.

Fig. -.. Saxidomus nuttallii Conrad. Right valve. Longitude, $97 \mathrm{~mm}$. 

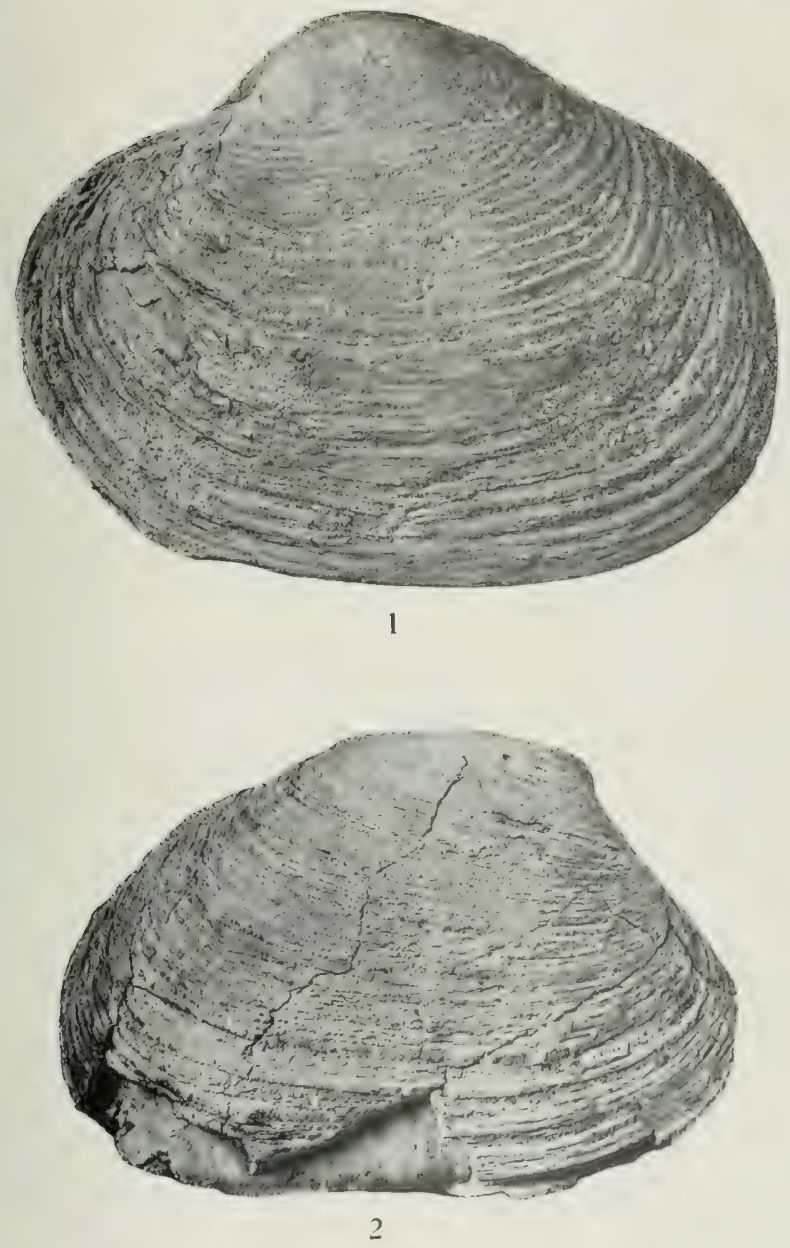



\section{EXPLANATION OF PLATE 58}

Fig. 1. Chione pabloensis? n. sp. Left valve. Longitude, $85 \mathrm{~mm}$. Natural size.

Fig. 2. Chione pabloensis, n. sp. Left valve. Longitude, $71 \mathrm{~mm}$. Approximately natural size.

Fig. 3. Spisula abscissa (Gabb). Redncel to less than one-half natural size.

Fig. 4. Chione diabolensis, n. sp. Left valve. Longitude, $44 \mathrm{~mm}$. Approximately natural size. 

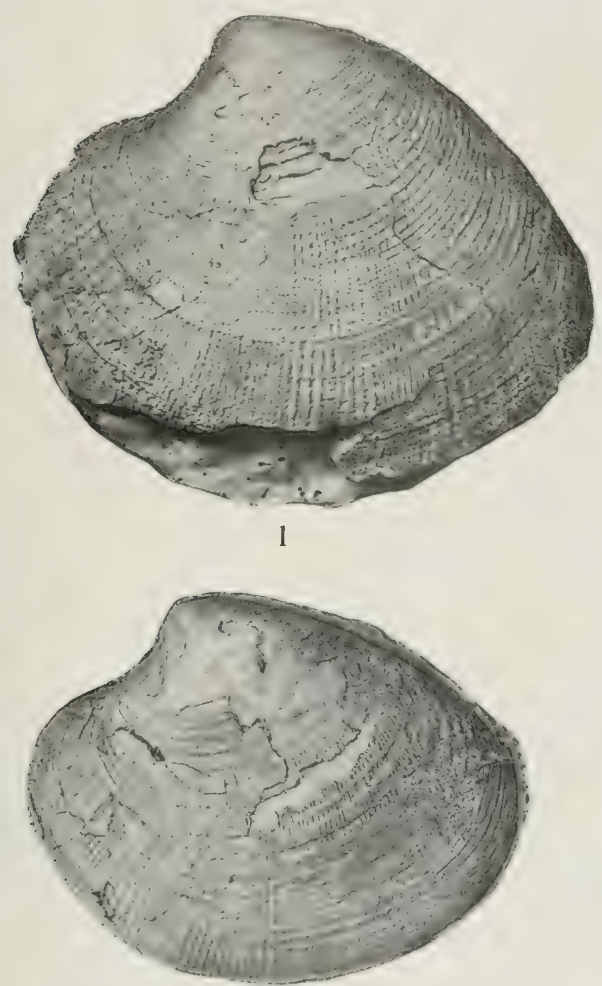

2

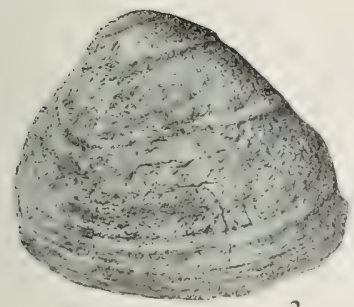

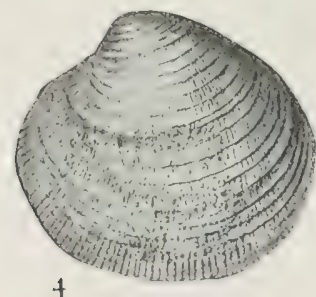

$+$ 

EXPLANATION OF PLATE 59

All figures approximately natural size

Fig. 1. Spisula catilliformis Conrad. Lougitude, $107 \mathrm{~mm}$.

Fig. ‥ Schizothue rus untallii conrad. Longitude, $111 \mathrm{~mm}$. 

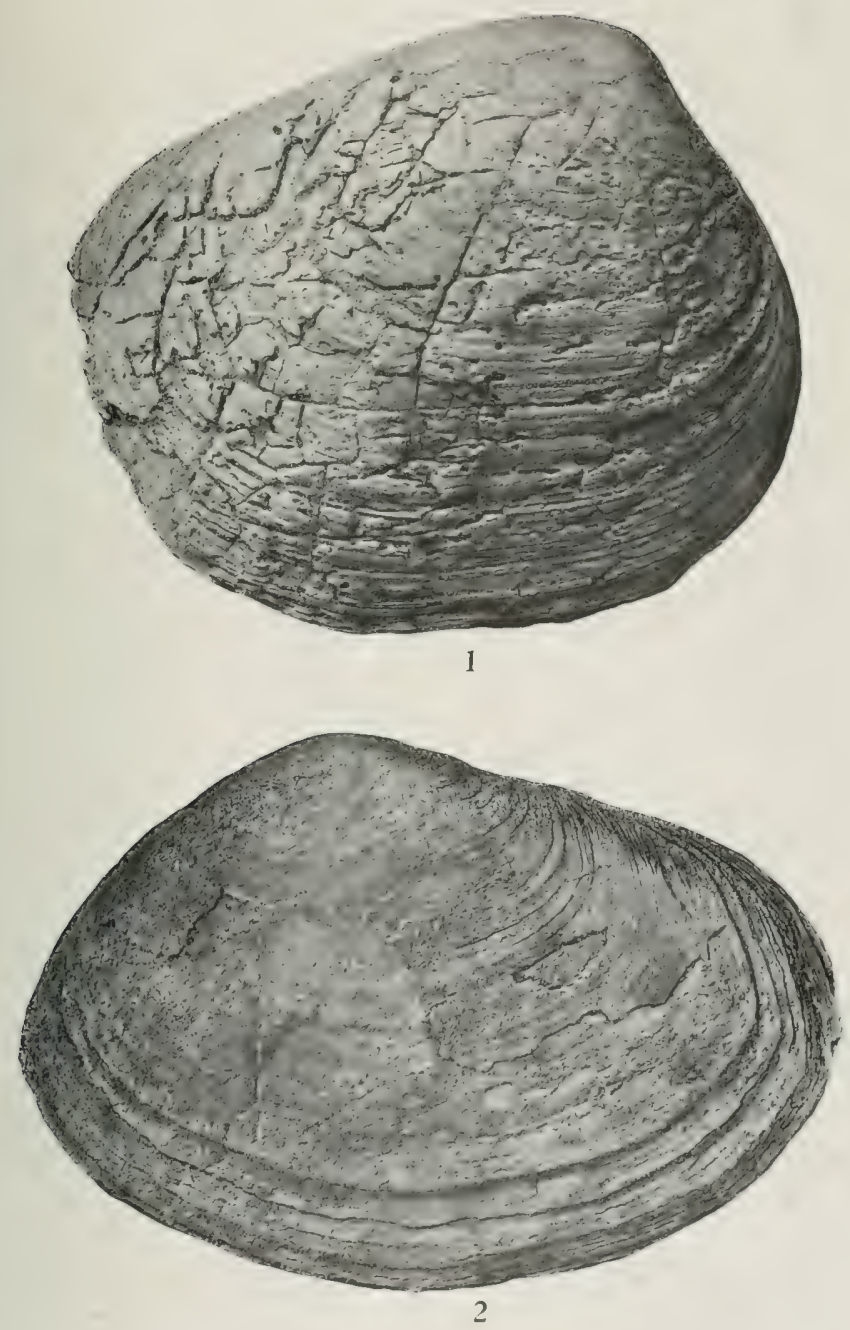



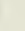




\section{EXPLANATJON OF PLATE 60}

All figures approximately natural size

Fig. 1. Iulinia pabloensis Packard, Left valve. Longitude, $81 \mathrm{~mm}$.

Fig. 2. Ifulinia pabloensis Packard. A small speeimen of left valve.

Fig. 3. Mya (Cryptomya) ovalis Conrad. Right valve. Longitude, $15 \mathrm{~mm}$.

Fig. 4. Ifya (Cryptomya) ovalis Conrad, Right valve, Longitude, $10 \mathrm{~mm}$.

Fig. 5. Mutinia densata Conrad. Left valve. Longitude, $53 \mathrm{~mm}$.

Fig. 6. Petricola buwaldi, n. sp. Right valve.

Fig. 7. Mulinia pabloensis Packard. Right valve. Longitude, $53 \mathrm{~mm}$.

Fig. \&. Spisula albaria Conrad. Left valve. Longitude, $51 \mathrm{~mm}$.

Fig. 9. Mactra trampasensis Packard. Right valve, Longitude, $36 \mathrm{~mm}$. 


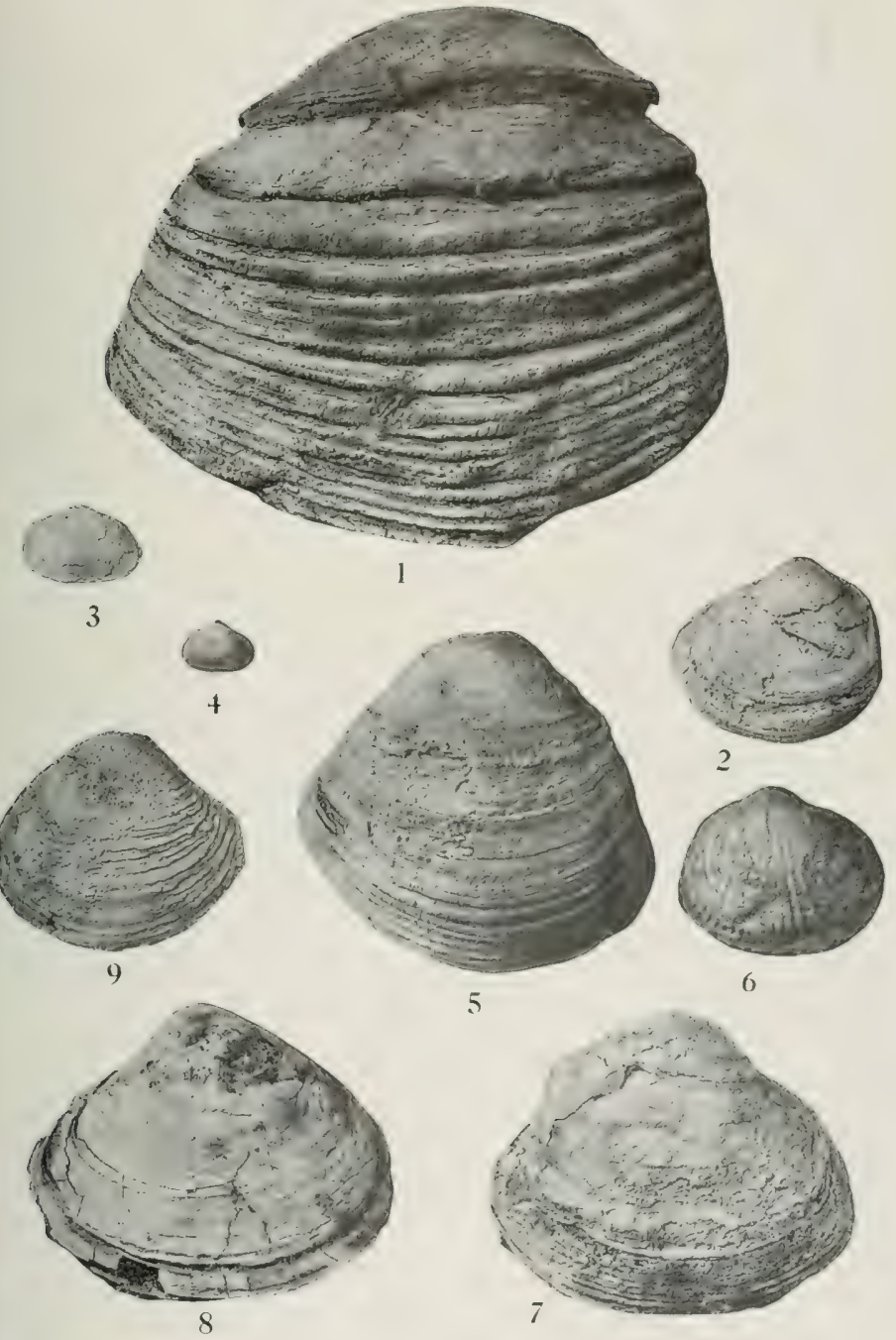



$\mid$ 


\section{EXPLANATION OF PLATE 61}

All figures approximately natural size

Tir. 1. IIacoma pabloensis, n, sp. Right valve. Longitude, $13 \mathrm{~mm}$.

Fig. :-. Macoma pabloensis, n. sp. Right valve. Longitude, $13 \mathrm{~mm}$.

Fig. :3. Tellina salmonea Carpenter. Right valve. Longitude, $9 \mathrm{~mm}$. Enlarged about twice.

Fig. 4. Tellina salmonea Carpenter. Left valve, Longitude, $11 \mathrm{~mm}$. Enlarged twice.

Fig. 5. Tellina diabloensis, n. sp. Right valve. Longitude, $37 \mathrm{~mm}$.

Fis. 6. Tellina englishi, n. sp. Left valve. Longitude, $40 \mathrm{~mm}$.

Fig. 7 . Tellina englishi, n. sp. Right valve of same specimen as figure 6 .

Iij. 3. Nacoma diabloensis, n. sp. Left valve. Longitude, $24 \mathrm{~mm}$.

Fis. 9. Ifacoma diabloensis, n. sp. Right valve. Longitude, $28 \mathrm{~mm}$.

Fin. 10. Macoma diabloensis, n. sp. Right valve. Longitude, $26 \mathrm{~mm}$.

Fin. 11. Tellina hannibali, n, sp. Right valve. Longitude, $35 \mathrm{~mm}$.

Fig. 12. Lacoma andersoni, w, sp. Left valve. Longitude, $31 \mathrm{~mm}$.

Fir. 13. Sanguinolarin? sp. indt. Right valve. Longitude, $27 \mathrm{~mm}$.

ris. 14. Sangrinolaria alata Gabb. Left valve. Longitude, $28 \mathrm{~mm}$.

17ig. 15. Sangunolaria mutallii Conrad. Left valve. Longitude, $16 \mathrm{~mm}$.

Iï.. 16. Macoma nasuta Conrad. Left valve.

Ii_. 17. Macoma pabloensis, n. sp. Left valve. Longitude, $20 \mathrm{~mm}$. 

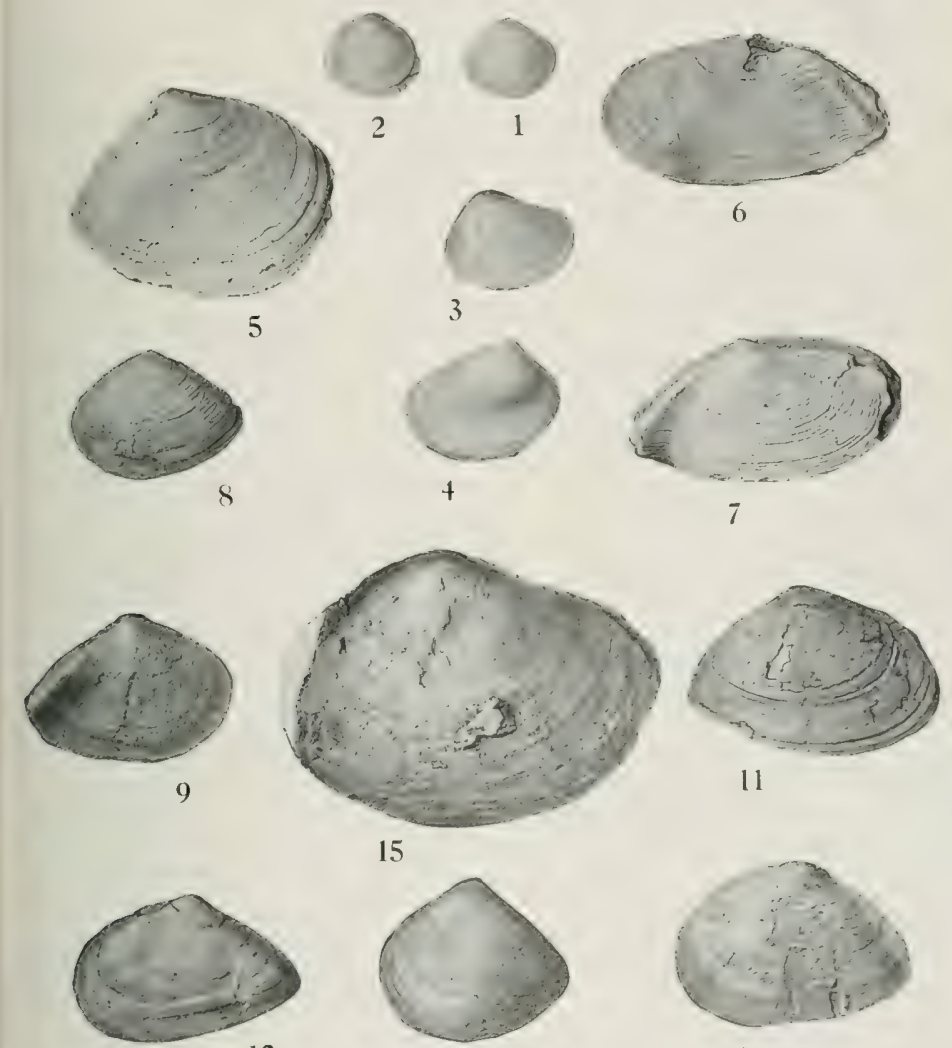

12
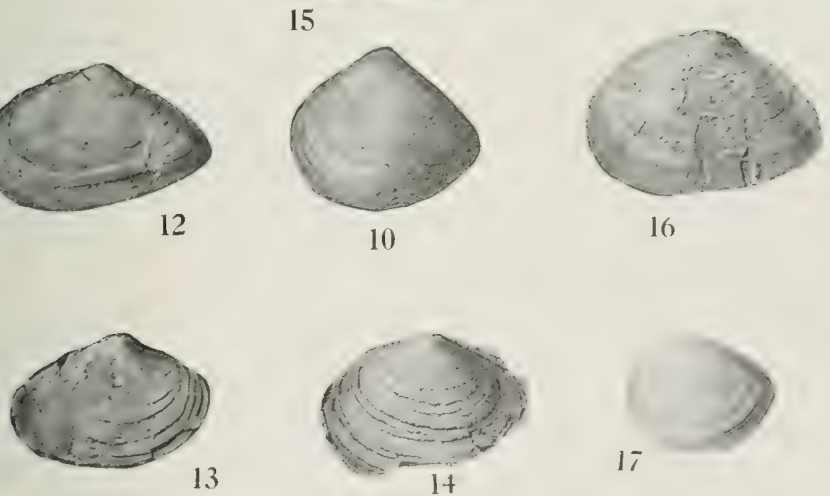



\section{EXPLANATION OF PLATE 62}

All figures approximately natural size

Fig. 1. Panope generosa Gould. Left valve. Longitude, $106 \mathrm{~mm}$.

Fig. 2. Phacoides richthofeni Gabb. Left valse. Longitude, $18 \mathrm{~mm}$.

Fig. 3. Phacoides tenuisculpta Carpenter. Right valve. Longitude, $6 \mathrm{~mm}$. Enlarged nearly twice natural size.

Fig. 4. Acila conradi Dall. Left valve. Longitude, $11 \mathrm{~mm}$.

Fig. 5. Sanguinolaria alata Gabb. Left valve. Longitude, $60 \mathrm{~mm}$.

Fig. 6. Diplodonta orbella Gould. Right valve. Longitude, $21 \mathrm{~mm}$.

Fig. 7. Mulinin pabloensis Packard. Left valve. Longitude, $93 \mathrm{~mm}$. 

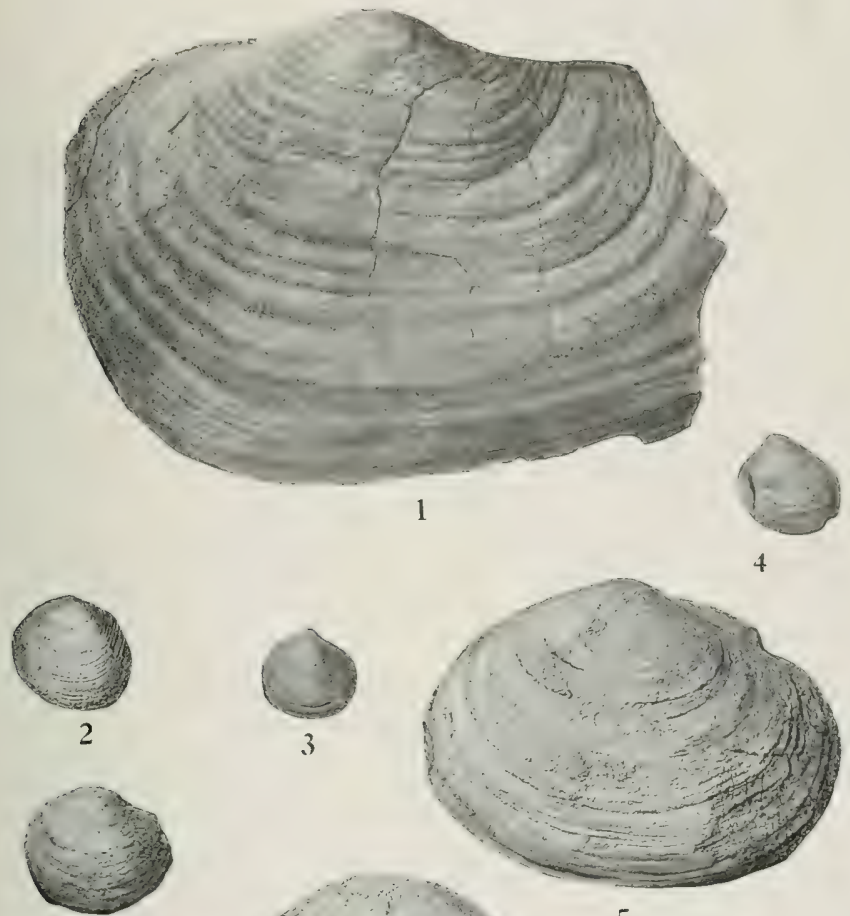

6
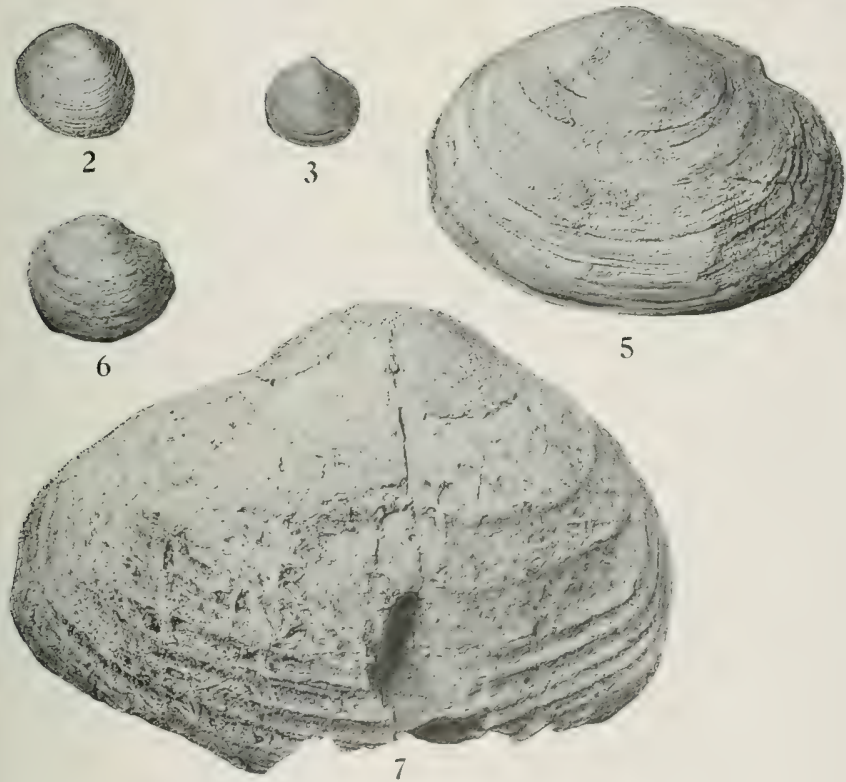



\section{EXPLANATION OF PLATE 63}

All figures approximately natural size

Fig. 1. Zirphaea dentata Gabb. View of left ralve. Longitude, $109 \mathrm{~mm}$.

Fig. 2. Zirphaea dentata Gabb. Dorsal view of same specimen as figure 1 .

Fig. 3. Mya dickersoni, $\mathrm{n}$, sp. Right valve. Longitude, $56 \mathrm{~mm}$.

Fig. 4. Mya dickersoni, n. sp. Left valve. Longitude, $51 \mathrm{~mm}$. 

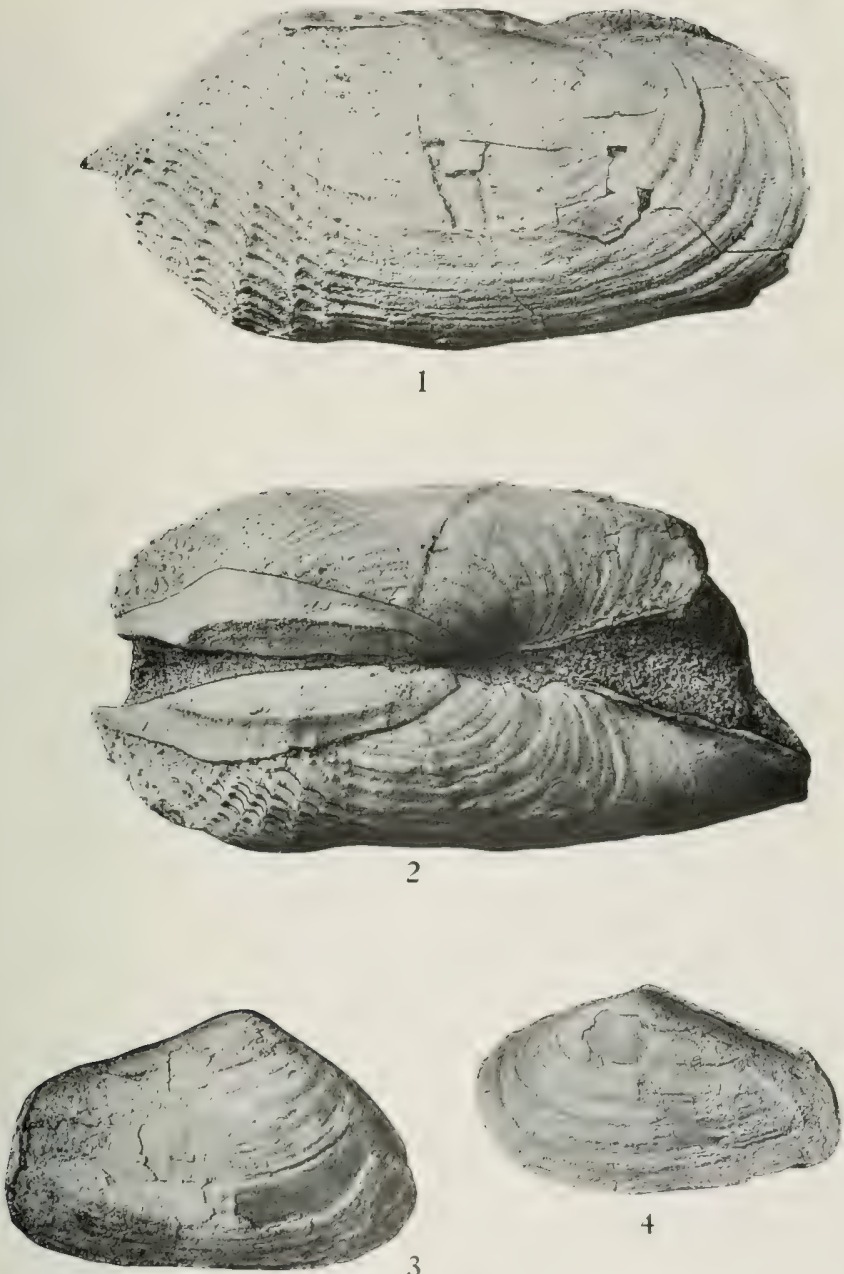



\section{EXPLANATION OF PLATE 64}

All figures approximately natural size

Fig. 1. Mya (Platydon) cancellatus (Conrad). Right valve. Longitude, $59 \mathrm{~mm}$.

Fig. 2. Metis alta Conrad. Left valve. Longitude, $45 \mathrm{~mm}$.

Fig. 3. Pecten bilineatus, n, sp. Right valve. Longitude, $46 \mathrm{~mm}$.

Fig. 4. Pecten bilineatus, n. sp. Left valve. Longitude, $36 \mathrm{~mm}$.

Fig. 5. Dosinia arnoldi, n. sp. Cast of left valve, showing eharacteristic ridge radiating from umbone toward ventral edge. Longitude, $82 \mathrm{~mm}$. 

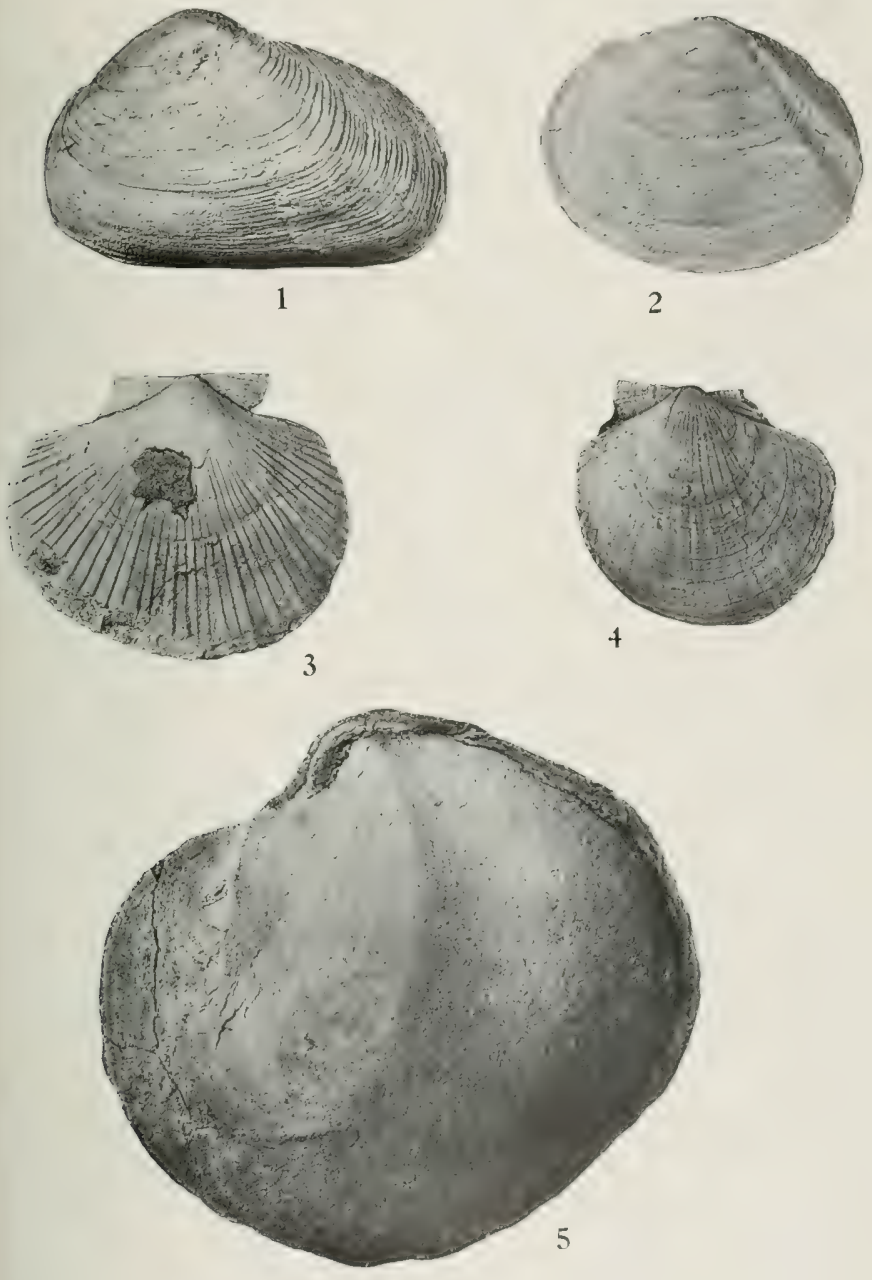



\section{EXPLANATION OF PLATE 65}

Fig. 1. Cerithopsis turneri, n, sp. Altitude, $15 \mathrm{~mm}$. Enlarged nearly twice natural size.

Fig. 2. Cerithiopsis turneri, n. sp. Altitude, $10 \mathrm{~mm}$. Enlarged nearly twice natural size.

Fig. 3. Bittium trampasensis, n. sp. Altitude, $7 \mathrm{~mm}$. Enlarged twiee natnral size.

Fig. 4. Bittium, sp. A. Altitude, $2 \mathrm{~mm}$. Enlarged about twice natural size.

Fig. 5. Bittium trampasensis, n. sp. Enlarged twice natural size.

Fig. 6. Tegula (Chlorestoma) nashi, n. sp. View of base, The color markings show plainly on this specimen. Natural size.

Fig. 7. Tegula (Chlorostoma) nashi, n. sp. Same specimen as figure 6 . Altitude, $12 \mathrm{~mm}$. Natural size.

Fig. 8. Nasa pablocnsis, n. sp. Altitude, $15 \mathrm{~mm}$. Enlarged twice natural size.

Fig. 9. Nassa pabloensis, n. sp. Altitude, $16 \mathrm{~mm}$. Enlarged twice natural size.

Fig. 10. Bittium? pabloensis, n, sp. Altitude, $16 \mathrm{~mm}$. Enlarged nearly twice natural size.

Fig. 11. Leptothyra danvillensis, n. sp. Altitude, $9 \mathrm{~mm}$. Enlarged nearly twice natural size.

Fig. 12. Leptothyra danvillensis, n. sp. Altitude, $11 \mathrm{~mm}$. Enlarged nearly twice natural size.

Fig. 13. Littorina rémondii Gabbi. Altitude, $11 \mathrm{~mm}$. Enlarged nearly twice natural size.

Fig. 14. Calliostoma bicarinatum, n. sp. Cotype. Altitude, $5 \mathrm{~mm}$. Enlarged a little over twice natural size.

Fig. 15. Astralium raymondi, n. sp. Cotype. Altitude, $14 \mathrm{~mm}$. Natural size.

Fig. 16. Astralizm raymondi, n. sp. Type. Altitude, $38 \mathrm{~mm}$. Natural size.

Fig. 17. Tegula (Chlorostoma) danvillensis, n. sp. Altitude, $7 \mathrm{~mm}$. Natural size.

Fig. 1s. T'egula (Chlorostoma) danvillensis, n. sp. Base of same specimen as figure 17. Natural size.

Fig. 19. Calliostoma bicarinatum, n. sp. Type. Altitude, 15 mm.

Fig. 20. Gadina reticulata Sowerby. Altitude, $22 \mathrm{~mm}$. Natural size.

Fig. 21. Calliostoma splendens, var. diabloensis, n, var. Enlarged trice natural size.

Fig. 22. Littorina pittsburgensis, n. sp. Altitude, $12 \mathrm{~mm}$. Enlarged twice natural size.

Fig. 23. Calytraea filosa Gabb. Altitude, $14 \mathrm{~mm}$. Natural size.

Fig. 24. Calytraea filosa Gabb. Top view of same specimen as figure 23. Natural size.

Fig. 25. Cerithiopsis bolingercnsis, n. sp. Altitude, about $7 \mathrm{~mm}$. Enlarged twice natural size. 

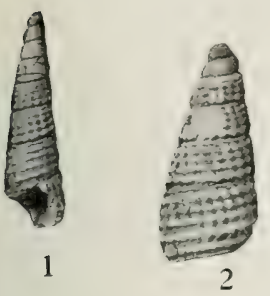

2
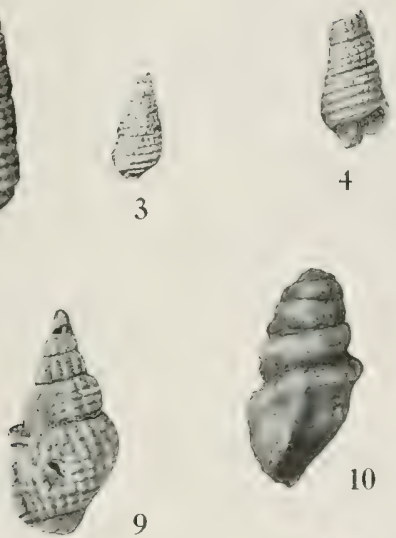

8
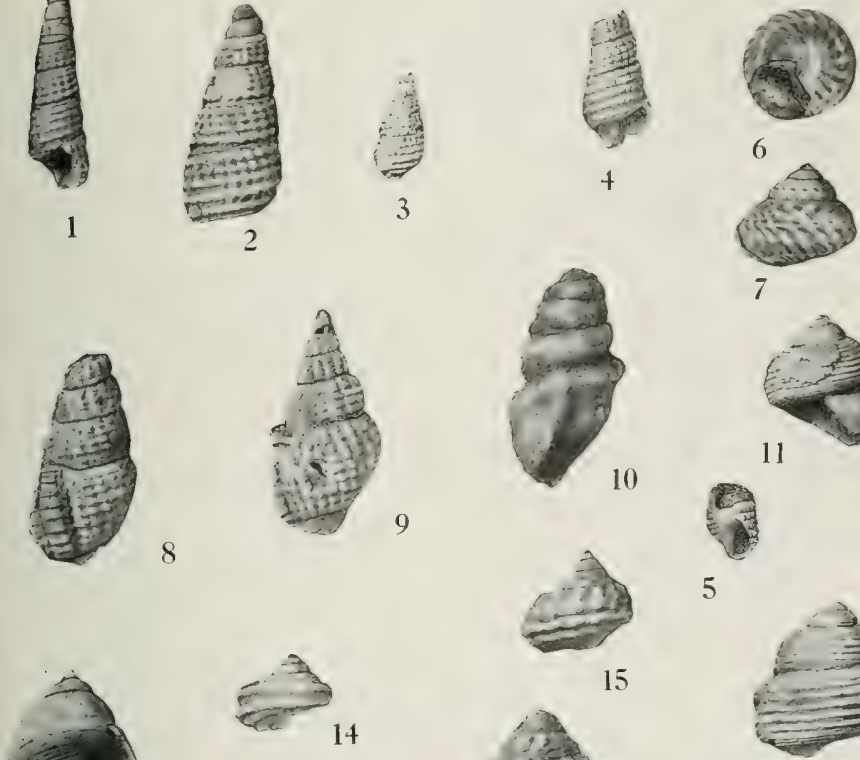

7

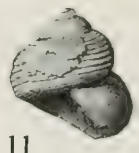

11
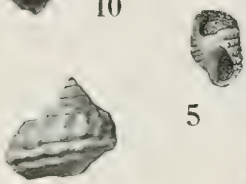

15

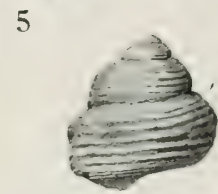

12

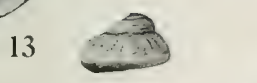

17

$\frac{153}{1+10}$

19
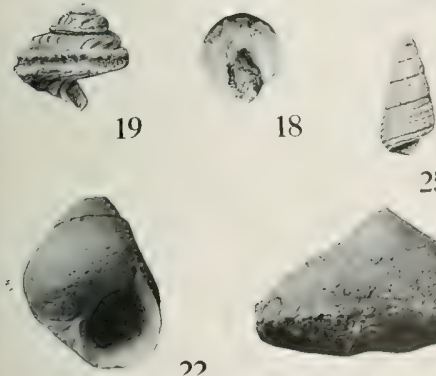

22

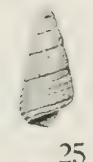

16
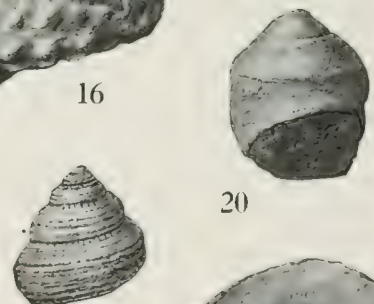

21

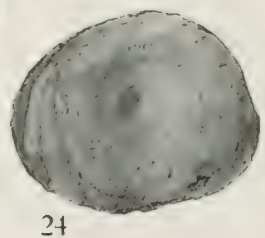





$$
\text { , }
$$




\section{EXPLANATION OF PLATE 66}

\section{All figures approximately natural size}

Fig. 1. Trophon carisaensis F. M. Anderson. Altitude, $69 \mathrm{~mm}$.

Fig. ?. Trophon carisaensis F. M. Anderson. Altitude, $61 \mathrm{~mm}$.

Fig. 3. Trophon ponderosum Gabb. Altitude, $56 \mathrm{~mm}$.

Fig. 4. Trophon ponderosum Gabb. Altitude, $41 \mathrm{~mm}$.

Fig. 5. Trophon ponderosum Gabb. var. diabloensis, n. var. Altitude, $59 \mathrm{~mm}$.

Fig. 6. Trophon gracilis Perry var. pabloensis, n, var. Altitude, $36 \mathrm{~mm}$.

Fig. 7. Trophon gracilis Perry var. pabloensis, n. var. Altitude, $34 \mathrm{~mm}$. 



\section{EXPLANATION OF PLATE 67}

All figures approximately natural size

Fig. 1. Chryodomus, sp. 8 Altitude, $33 \mathrm{~mm}$.

Fig. 2. Murex (ocinebra) selbyensis, n, sp. A common species in the Lower San Pablo. Altitude, $35 \mathrm{~mm}$.

Fig. 3. Bursa trampasensis, n. sp. Altitude, $60 \mathrm{~mm}$.

Fig. 4. Murex (Ocinebra) dalli, n, sp. A eommon species in the Upper San Pablo. Altitude, $23 \mathrm{~mm}$.

Fig. 5. Murex (Ocinetra) selbyensis, n. sp. Altitude, $18 \mathrm{~mm}$.

Fig. 6. Siphonalia pabloensis, $\mathrm{n}$. sp. A Atitude, $32 \mathrm{~mm}$.

Fis. T. Murex (Ocinebra) selbyensis, n. sp. Altitude, $17 \mathrm{~mm}$.

Fig. S. Chrysodomus pabloensis, n, sp. Type. Altitude, $59 \mathrm{~mm}$.

Fig. 9. Murex (Ocinebra) dalli, n. sp. Altitude, $29 \mathrm{~mm}$.

Fig. 10. Trophon lawsoni, n. sp. Altitude, $92 \mathrm{~mm}$.

Fig. 11. Trophon lawsoni, n. sp. Top view of another specimen showing character of varices. 

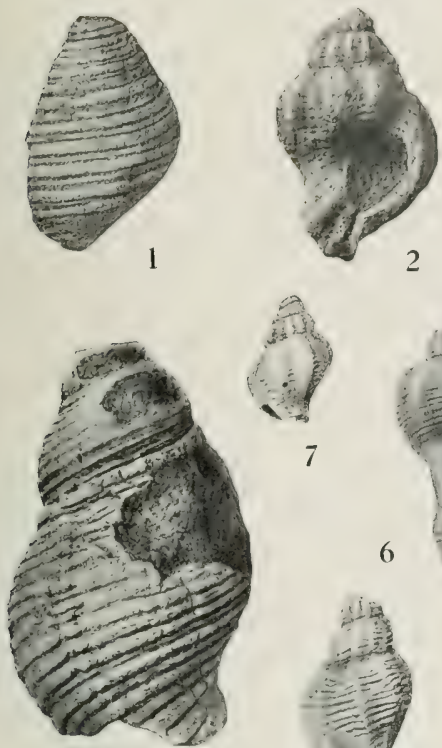

8
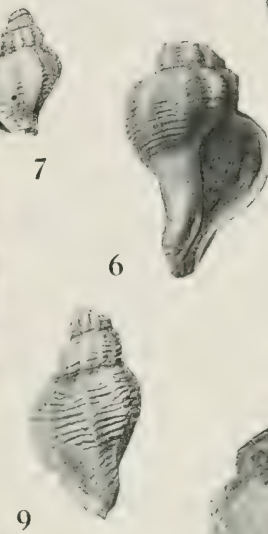
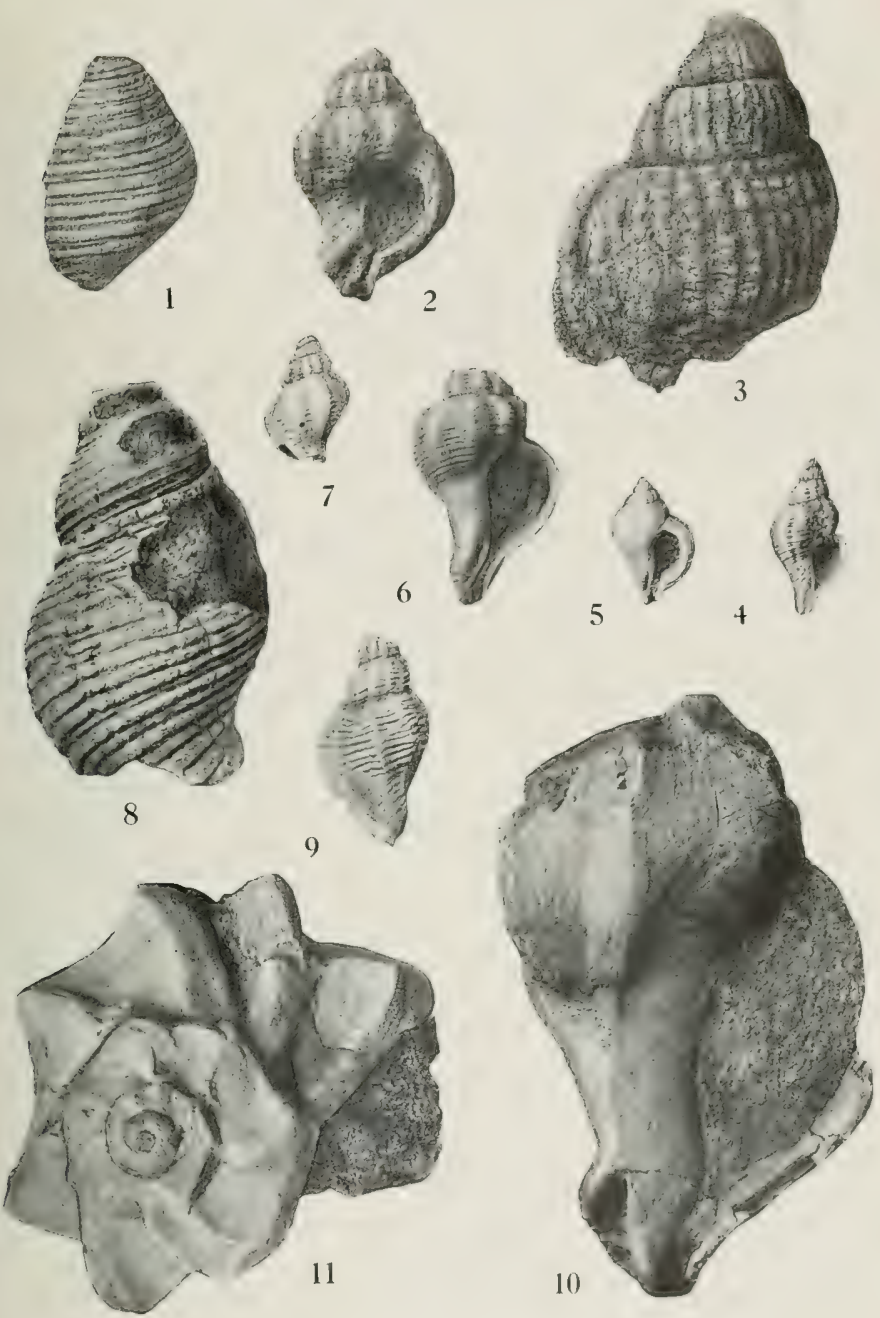



\section{EXPLANATION OF PLATE 68}

All figures approximately natural size

Fig. 1. Chrysodomus cierboensis, n. sp. Altitude, $48 \mathrm{~mm}$.

Fig. 2. Chrysodomus imperialis Dall. Altitude, $37 \mathrm{~mm}$.

Fig. 3. Chrysodomus diabloensis, n. sp. Altitude, $25 \mathrm{~mm}$.

Fig. 4. Chrysodomus bucaldi, n. sp. Altitude, $26 \mathrm{~mm}$.

Fig. 5. Trophon dickersoni, n, sp. Altitude, $20 \mathrm{~mm}$.

Fig. 6. Trophon dickersoni, n. sp. Spire of specimen somewhat crushed. Altitude, $21 \mathrm{~mm}$.

Fig. 7. Natica (Euspira) diabloensis, n. sp. Altitude, $43 \mathrm{~mm}$.

Fig. 8. Thais lima Martyn. Altitude, $27 \mathrm{~mm}$.

Fig. 9. Cancellaria pabloensis, n. sp. Cotype. Altitude, $24 \mathrm{~mm}$.

Fig. 10. Hemifusus dalli, n. sp. Enlarged twice natural size.

Fig. 11. Cancellaria pabloensis, n. sp. Type. Altitude, $33 \mathrm{~mm}$. A common species in the Upper San Pablo.

Fig. 12. Natica (Neverita) pabloensis, n. sp. Altitude, $39 \mathrm{~mm}$.

Fig. 13. Natica (Neverita) arnoldi, n. sp. Altitude, $39 \mathrm{~mm}$.

Fig. 14. Natica (Neverita) pabloensis, n. sp. Altitude, $27 \mathrm{~mm}$.

Fig. 15. Natica (Neverita) arnoldi, n. sp. Front view of same specimen as figure 13 . 

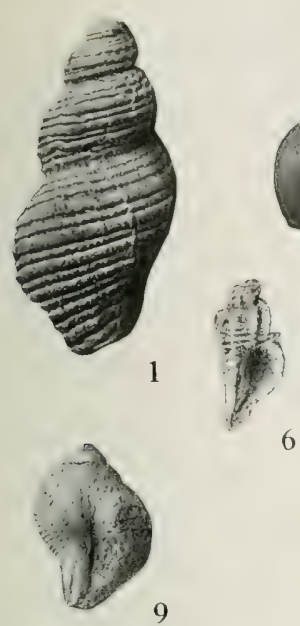

6

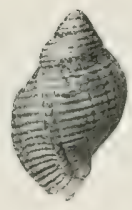

8

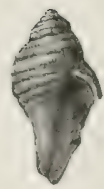

4
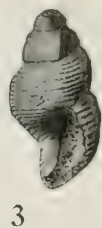

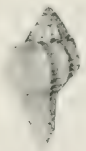

5
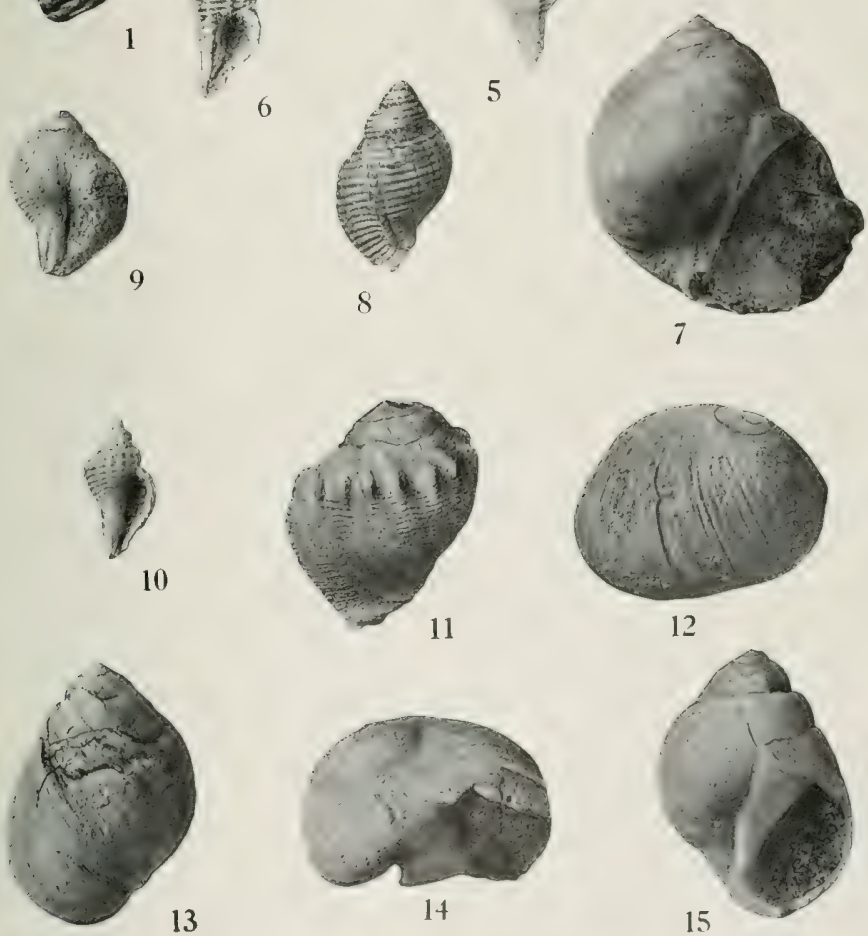

12

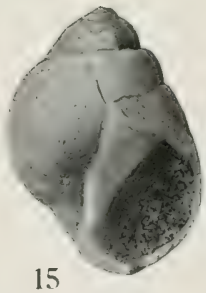






\section{EXPLANATION OF PLATE 69}

Fig. 1. Cerithiam rodeoensis, n. sp. Altitude, $17 \mathrm{~mm}$. Neither of the specimens figured shows the longitudinal ribbing usually seen on the whorls of the spire. Natural size.

Fig. 2. Hurex (Ocinebra) packardi, n. sp. Altitude, $41 \mathrm{~mm}$. Natural size.

Fig. 3. Olivella pedroana Conrad. Altitude, $15 \mathrm{~mm}$. Natural size.

Fig. 1. Natice (Euspira) kirkensis, n. sp. A very common species in the Lower San Pablo; also found in the Scutella breweriana zone. Altitude, $32 \mathrm{~mm}$. Natural size.

Fig. 5. Turris kirkensis, n. sp. Altitude, 13 mm. Enlarged twice natural size.

Fig. 6. Turris krkensis, n. sp. Enlarged twice natural size.

Fig. 7. Turris kirkcnsis, n. sp. Altitude, $10 \mathrm{~mm}$. Enlarged twice natural size.

Fig. 8. Columbella kirkensis, n. sp. Altitude, $10 \mathrm{~mm}$. Enlarged twice natural size.

Fig. 9. Natice (Euspira) kirkensis, n. sp. Altitude, $35 \mathrm{~mm}$.

Fig. 10. Cerithium rodeoensis, д. sp. Altitude, $15 \mathrm{~mm}$. Enlarged twice natiral size.

Fig. 11. Murex (Ocinebra) paclardi, n. sp. Altitude, $31 \mathrm{~mm}$. Natural size. 

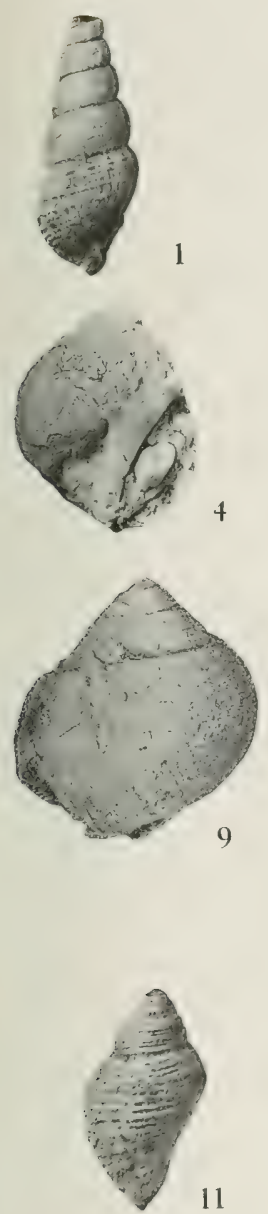

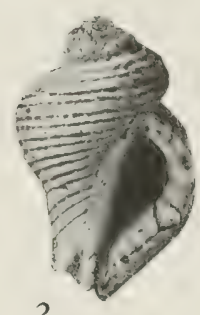

3

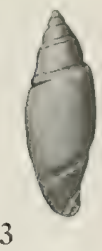

6

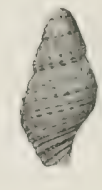

5

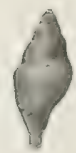

8

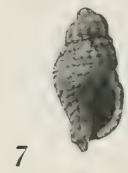

10

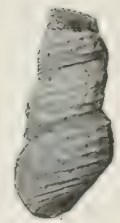



EXPLANATION OF I'LATE 70

All figures approximately natural size

Fier. 1. Crepidula pabloensis, n. sp. Showing coneave deck.

Fig. :. Crepidula pabloensis, n. sp. Altitude, $22 \mathrm{~mm}$.

Fig. 3. Crepidula pabloensis, n. sp. Altitude, $20 \mathrm{~mm}$.

Fì. t. Cerithiopsis, sp. A.

Fig. 5. Cerithiopsis, sp. A.

Firg. 6. Crepidula adunca Sowerby. Altitude, $10 \mathrm{~mm}$.

Fig. 7. Crepidula pabloensis, n. sp. Type. Altitude, $20 \mathrm{~mm}$.

Fig. - Calyptraca martini, n. sp. Altitude, $28 \mathrm{~mm}$.

lï. (f. Calyptraca diabloensis, n. sp. Altitude, about $25 \mathrm{~mm}$. 
UNIV. CALIF. PUBL. BULL. DEPT. GEOL.
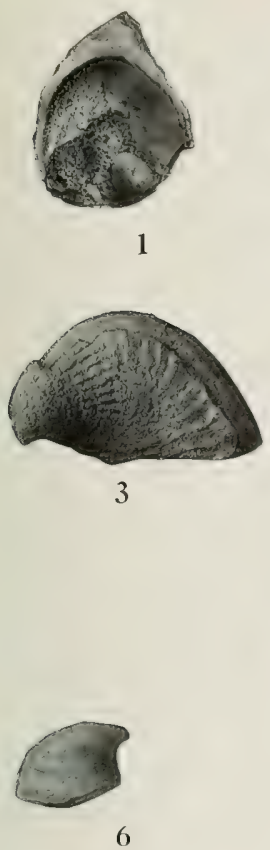

5

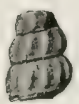

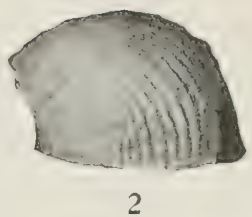
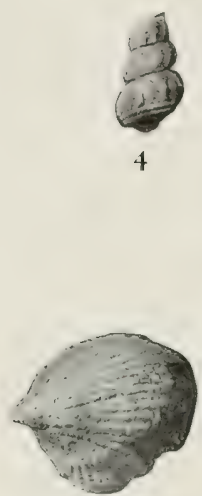

7
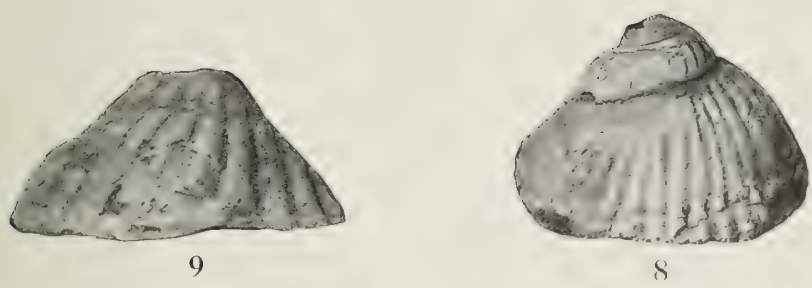



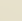


EXPLANATION OF PLATE 71

Map showing distribution of San Pablo Group and portion of the Monterey Group in the region of San Pablo Bay.

$[572]$ 


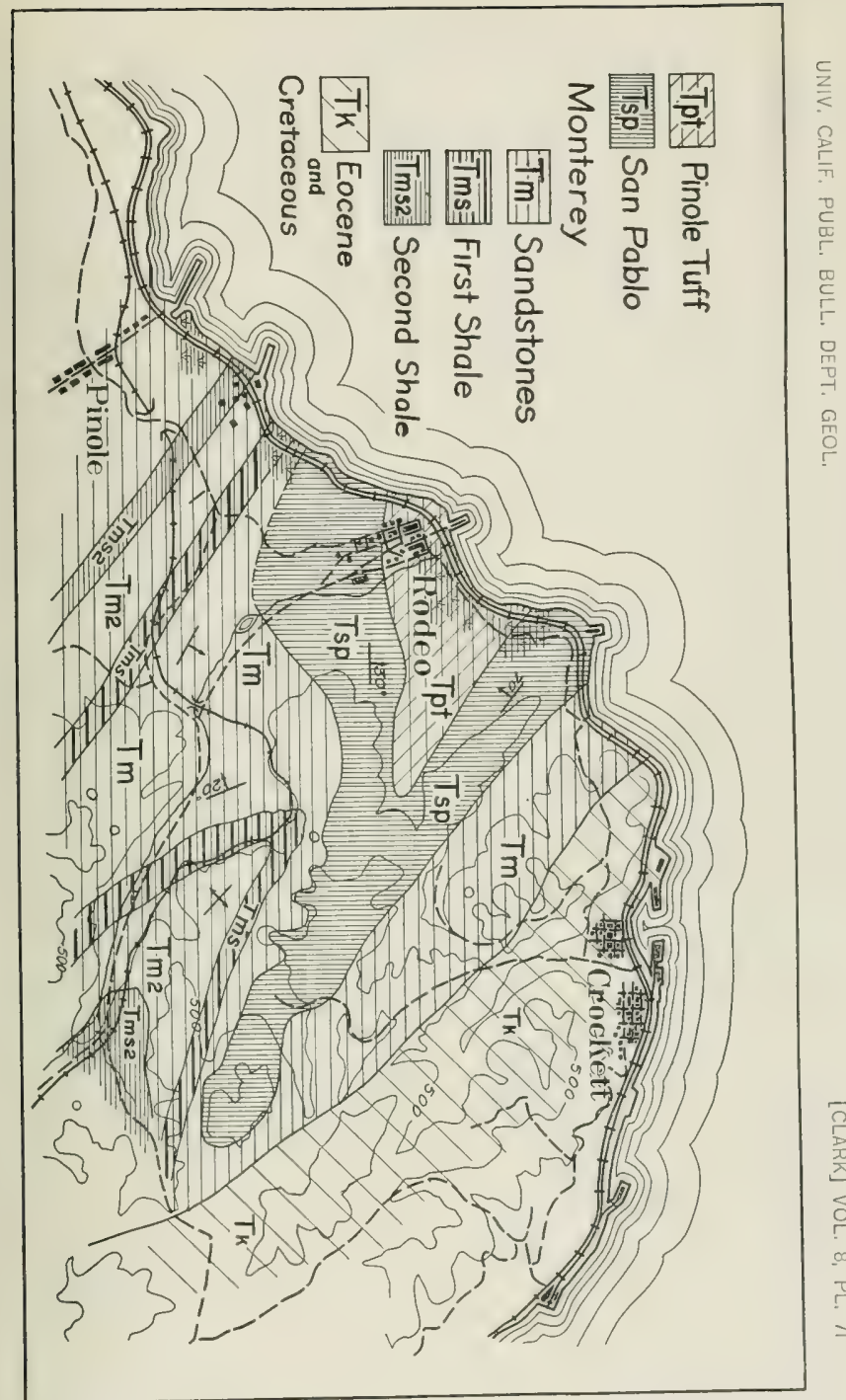



$+$ 




PLEASE DO NOT REMOVECARDS OR SEIPS FROM THIS POCKET UNIVERSITY OF TORONTO LIBRARY

Colemai Library Department of Geology Univer ity of Toronto 


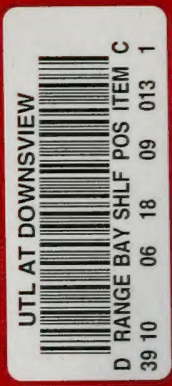

